\title{
FREIGHT SHUTTLE SYSTEM: CROSS-BORDER MOVEMENT OF GOODS
}

Feasibility Assessment

Report Number: 477770-00001 - Final

Sponsor Award Number: DE-EE0001090

Sponsor Project Title: Center for International Intelligent Transportation Research

August 2011

Report prepared by

Center for International Intelligent Transportation Research

Texas Transportation Institute

4050 Rio Bravo, Suite 151

El Paso, TX 79902

TEXAS TRANSPORTATION INSTITUTE

The Texas A\&M University System

College Station, Texas 77843-3135 


\section{DISCLAIMER}

This report was prepared as an account of work sponsored by an agency of the United States Government. Neither the United States Government nor any agency thereof, nor any of their employees, makes any warranty, express or implied, or assumes any legal liability or responsibility for the accuracy, completeness, or usefulness of any information, apparatus, product, or process disclosed, or represents that its use would not infringe privately owned rights. Reference herein to any specific commercial product, process, or service by trade name, trademark, manufacturer, or otherwise does not necessarily constitute or imply its endorsement, recommendation, or favoring by the United States Government or any agency thereof. The views and opinions of authors expressed herein do not necessarily state or reflect those of the United States Government or any agency thereof. 
List of Figures. viii

List of Tables ix

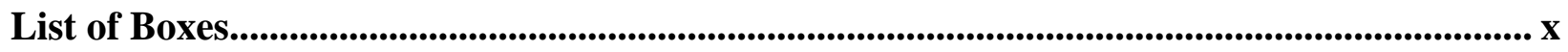

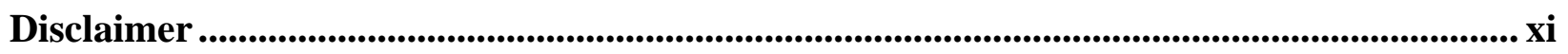

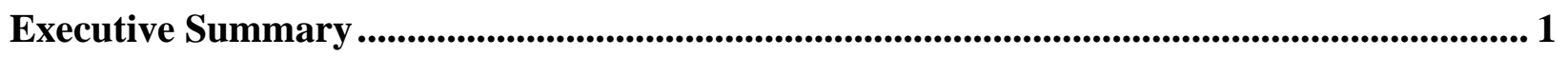

The Problem: The United States Lacks a Sustainable Freight Transportation System ............. 1

The Solution: The Freight Shuttle System................................................................... 1

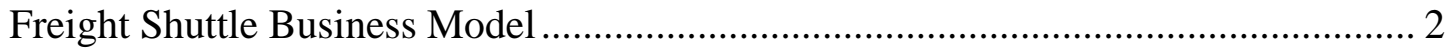

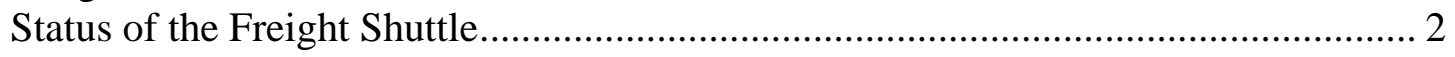

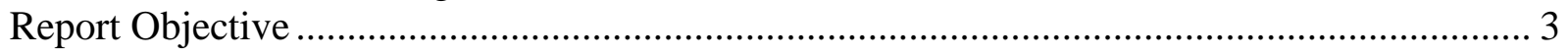

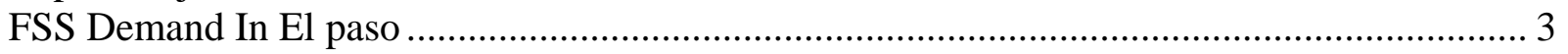

Changes to Logistics Practices in El Paso .................................................................. 4

Change in Truck Vehicle Miles Traveled with FSS Implementation........................... 4

Benefits of the FSS in El Paso .................................................................................. 5

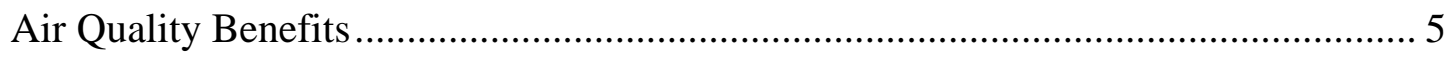

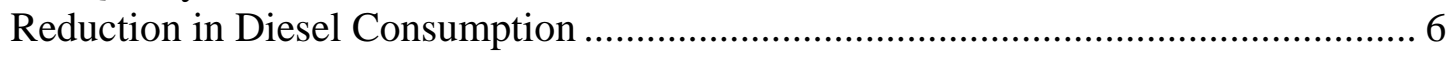

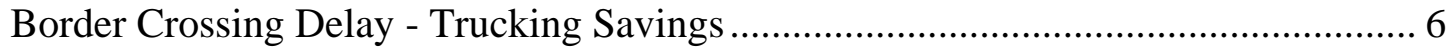

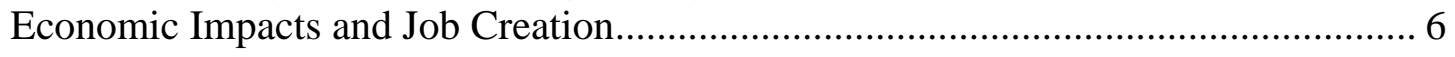

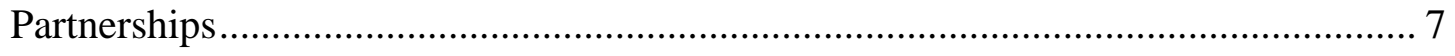

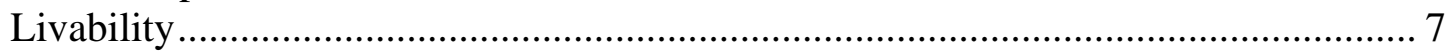

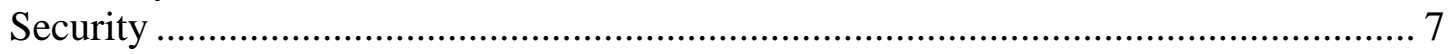

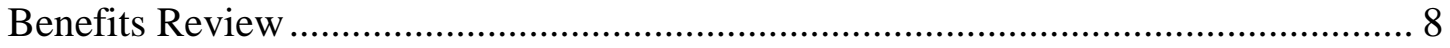

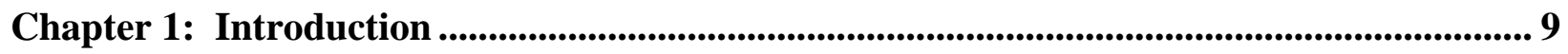

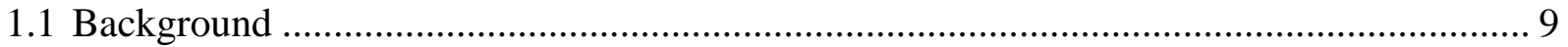

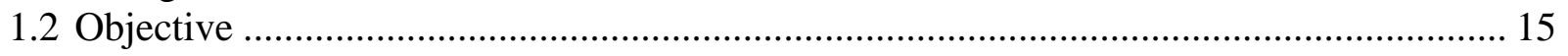

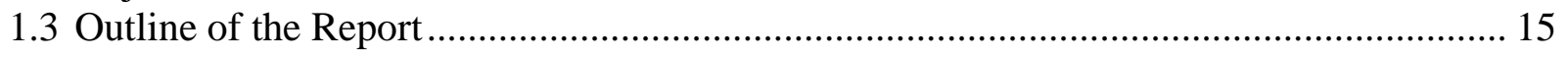

Chapter 2: Cross-Border Container Moves-Demand Analysis ......................................... 17

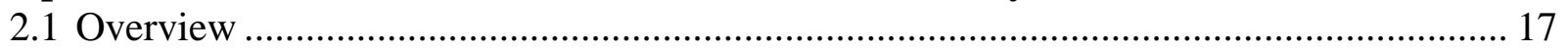

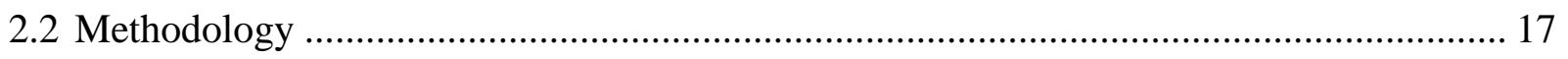

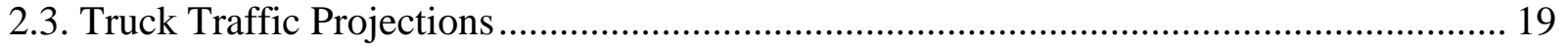

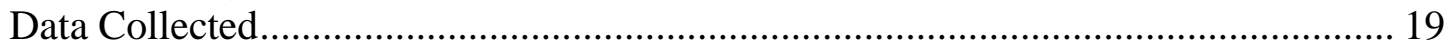

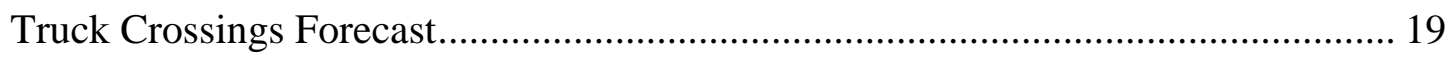

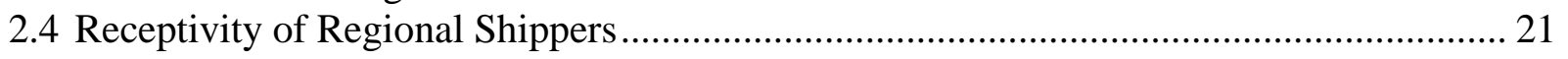

Market Capture Rate Probability Model .......................................................... 21

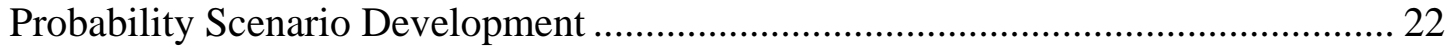

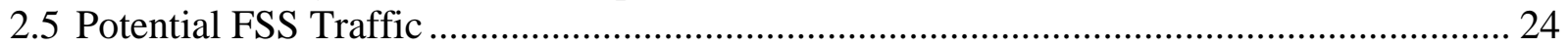

2.6 Chapter Summary and Recommendations .............................................................. 26 
Chapter 3: Changes to Logistics Practices ....................................................................................... 27

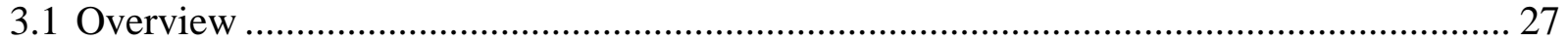

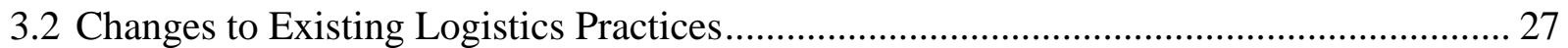

3.3 Change in Truck Vehicle Miles Traveled with FSS Implementation ................................ 29

Identification of Industrial Areas .......................................................................... 30

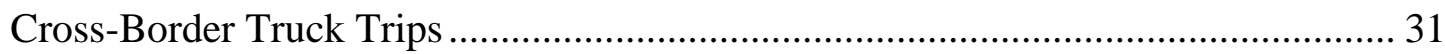

Vehicle Miles Traveled Calculation ...................................................................... 32

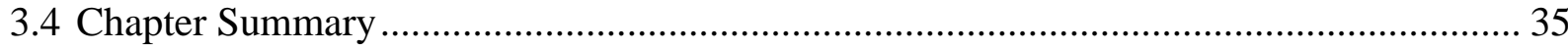

Chapter 4: Terminals and Border Crossing Target Locations ................................................... 37

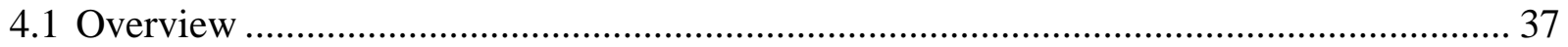

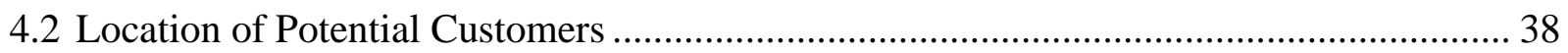

El Paso Industrial Cluster Locations......................................................................... 40

Ciudad Juarez Industrial Clusters Location ............................................................... 43

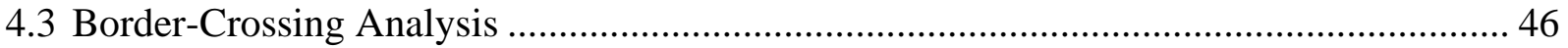

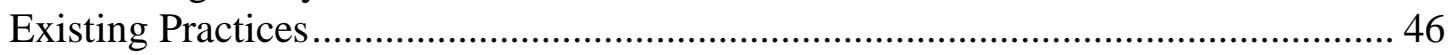

Ysleta-Zaragoza Bridge ................................................................................... 48

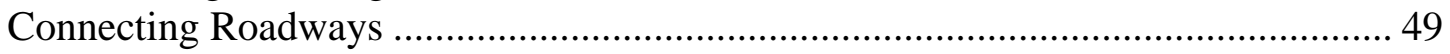

4.4 Regional Growth and Development Plans .................................................................... 49

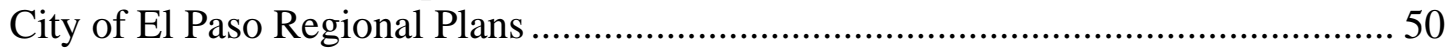

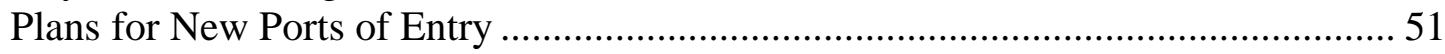

Ciudad Juarez Regional Plans............................................................................... 52

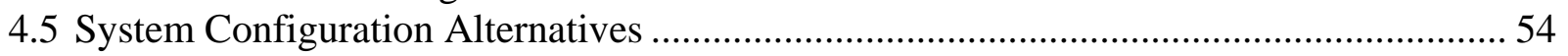

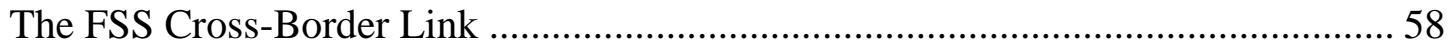

Alternative Inspect-in-Motion Facilities.................................................................. 58

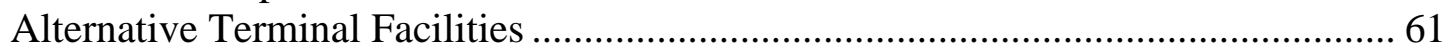

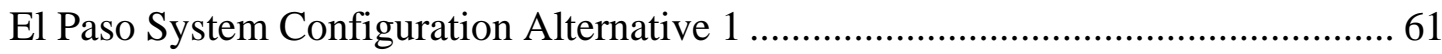

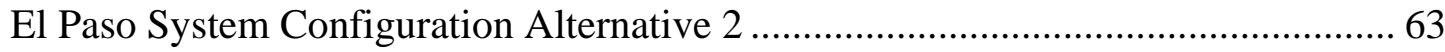

El Paso System Configuration Alternative 3 .......................................................... 65

CDJ Terminal Facility Alternative 1 .................................................................... 67

CDJ Terminal Facility Alternative 2................................................................ 70

CDJ Terminal Facility Alternative 3 …………………………………………..... 72

4.6 Chapter Summary and Recommendations …………………………………………….... 74

Chapter 5: Analysis of Regulatory and Institutional Frameworks, and Assessment of Management Models ........................................................................................................................ 75

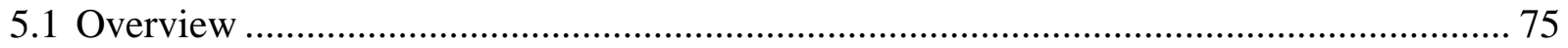

5.1 Regulatory Framework for Binational Implementation ...................................................... 76

U.S. Federal Legal Framework …………………………..................................... 76

State of Texas Legal Framework ......................................................................... 79

Mexican Federal Legal Framework ......................................................................... 79

State of Chihuahua - State and Local Legal Framework ………………………….... 82

5.2 Commercial Border Crossing — Institutions .................................................................... 84

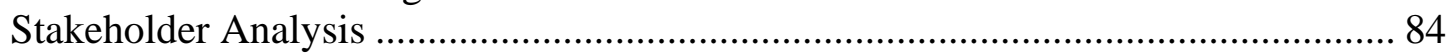

Stakeholder Mapping …………………….......................................................... 90

5.4 Binational Institutional Model for Operations ……………............................................... 93

5.5 Binational Business Management Structure..................................................................... 97 


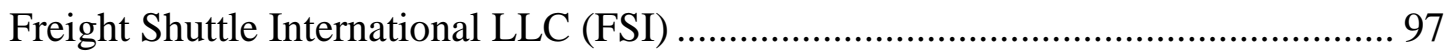

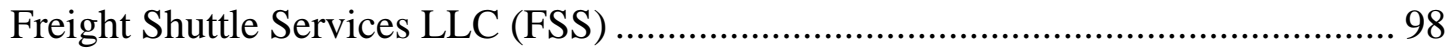

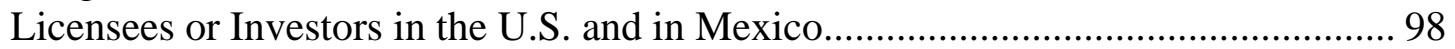

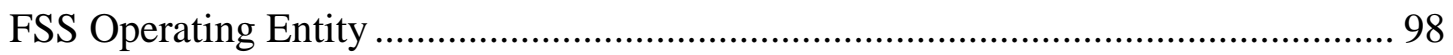

5.6 Chapter Summary and Recommendations ........................................................... 99

Chapter 6: Assessment of Security and Power Usage ............................................................ 101

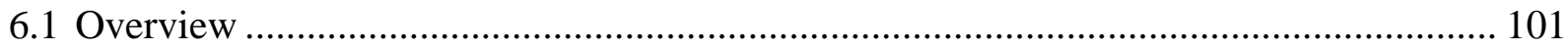

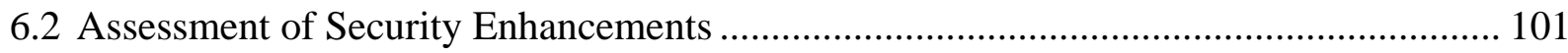

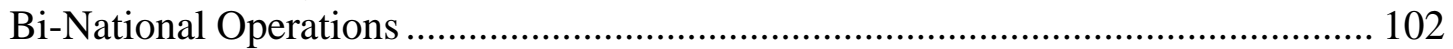

6.3 Electricity Review for FSS Cross-border Operations .............................................. 102

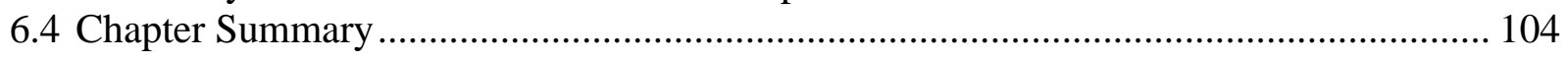

Chapter 7: Benefits Review................................................................................................ 105

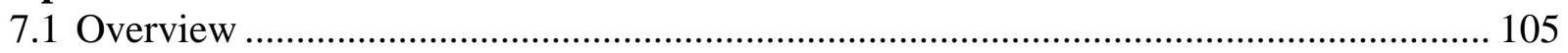

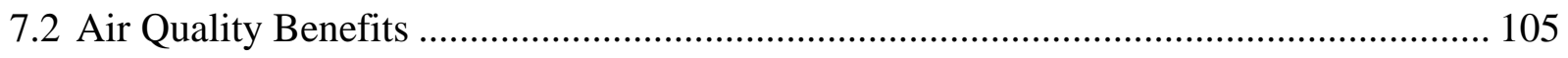

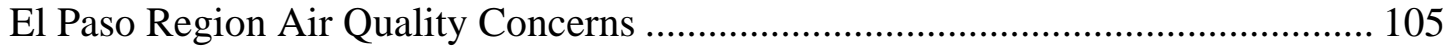

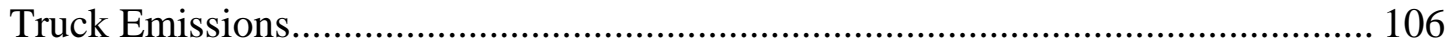

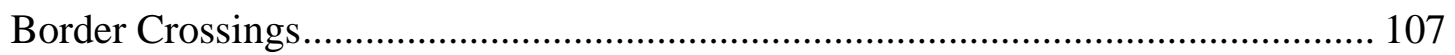

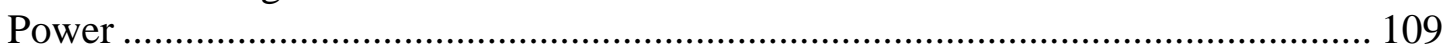

Combined Emission Analysis ..................................................................... 110

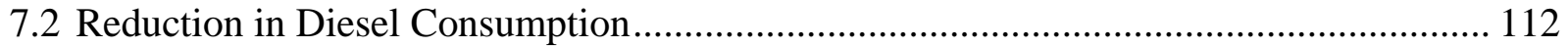

7.3 Border Crossing Delay - Trucking Savings .............................................................. 113

7.4 Economic Impacts and Job Creation ..................................................................... 113

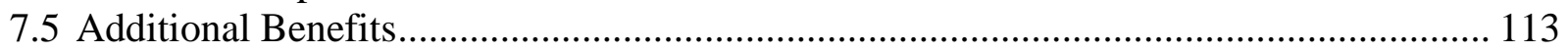

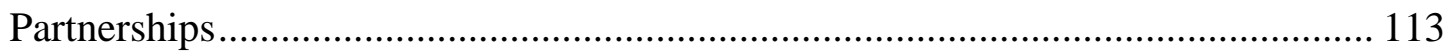

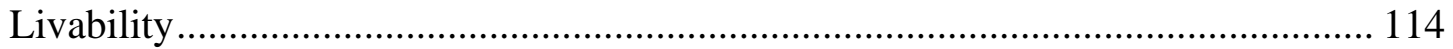

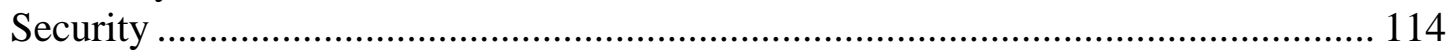

7.6 Benefits Review ................................................................................................. 114

Appendix A: Survey Applied to Maquiladoras in the Region ................................................ 117

Appendix B: Border-Crossing Analysis....................................................................................... 119

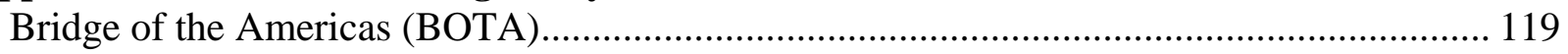

Santa Teresa, NM............................................................................................ 120

Appendix C: Process for Evaluation of Proposals for New Border Crossings and

Bridges in the U.S. and Mexico..................................................................................... 121

Interpretative Guidance on Executive Order 11423 .................................................... 121

Process for Evaluation of Proposals for New Border Crossings and Bridges in Mexico....... 128

Appendix D: FSS Annual Demand-Results from Monte Carlo Simulation (after Opening)............................................................................................................................................. 131

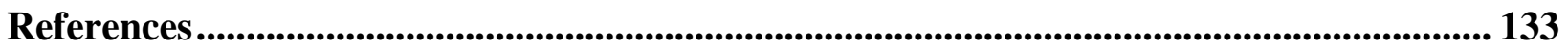


Figure 1. Methodology for the FSS Demand Analysis .................................................... 18

Figure 2. Total Border Crossing Trucks Volumes Historic and Forecast (NB and SB)............ 20

Figure 3. FSS Minimum, Maximum and Most Likely Market Capture ................................... 25

Figure 4. Map of El Paso Commercial Bridges and Industrial Areas...................................... 28

Figure 5. Comparison of Existing and FSS Truck Flows in the El Paso Area ......................... 29

Figure 6. FSS Target-Market Location: Industrial Operations in El Paso - Cd. Juarez .............. 39

Figure 7. Location of Main Industrial Parks and Industrial Parcels in El Paso ........................ 42

Figure 8. Location of Main Industrial Parks and Maquiladoras in Ciudad Juarez .................... 45

Figure 9. Historical Truck Volumes for BOTA and Zaragoza Ports of Entry......................... 47

Figure 10. Aerial Image of the Ysleta-Zaragoza POE ........................................................... 48

Figure 11. Ysleta-Zaragoza Port of Entry Roadways-FSS Proposed Border-Crossing ........... 49

Figure 12. Existing and Proposed Ports of Entry ............................................................... 52

Figure 13. Ciudad Juarez Urban Zones and Land Reserved for Urban Growth....................... 53

Figure 14. Alternatives for System Configuration for El Paso Terminals................................ 56

Figure 15. Alternatives for System Configuration for Ciudad Juarez Terminals ...................... 57

Figure 16. The FSS Cross-border Link connecting Inspect-in-Motion Facilities A-A .............. 59

Figure 17. The FSS Cross-border Link connecting the Inspect-in-Motion Facility B-A ........... 60

Figure 18. FSS Terminal Facility Drawing...................................................................... 61

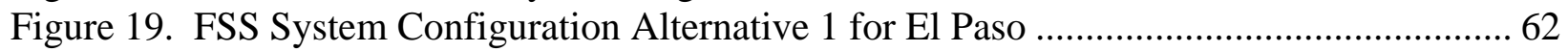

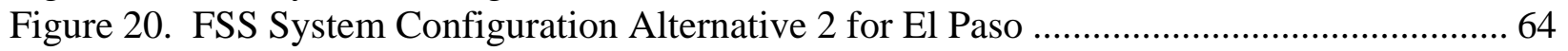

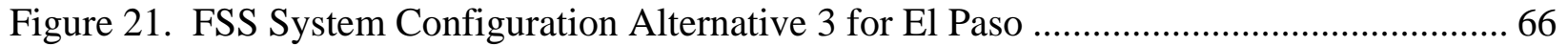

Figure 22. FSS System Configuration Alternative 1 for Ciudad Juarez................................... 68

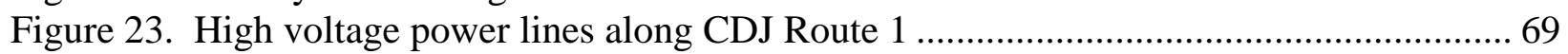

Figure 24. The Transition Scenario at Boulevard Independencia for CDJ Route 1 .................. 69

Figure 25. The Intersection with Boulevard Santiago Blancas on CDJ Route 1 ..................... 70

Figure 26. FSS System Configuration Alternative 2 for Ciudad Juarez................................. 71

Figure 27. FSS System Configuration Alternative 3 for Ciudad Juarez............................... 73

Figure 28. FSS Institutional Model for Binational Operations ............................................ 96

Figure 29. FSS Proposed Binational Management Strategy .............................................. 100

Figure 30. El Paso Electric Service Area......................................................................... 103

Figure 31. Bridge of the Americas (BOTA)_FSS Border Crossing Alternative No.2 ........... 119

Figure 32. Santa Teresa Port of Entry-FSS Border Crossing Alternative No.3 ................... 120

Figure 33. Process for the Evaluation of Proposals for New Border Crossings and

Bridges (Part 1).

Figure 34. Process for the Evaluation of Proposals for New Border Crossings and

Bridges (Part 2). 130 


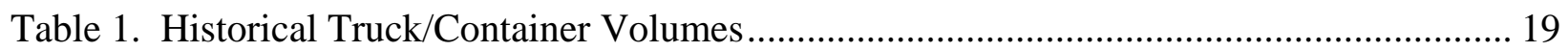

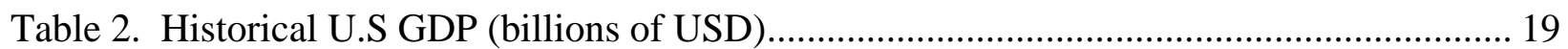

Table 3. Total Border Crossing Trucks Volumes Forecast (NB and SB)................................... 20

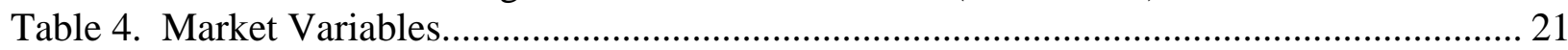

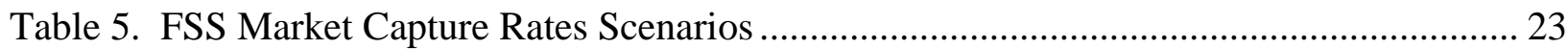

Table 6. Potential FSS Cross-Border Container Moves. ............................................................ 24

Table 7. El Paso BOTA Bridge, Industrial Areas, Trip Distances, and VMT .............................. 30

Table 8. El Paso Zaragoza Bridge, Industrial Areas, Trip Distances, and VMT.......................... 31

Table 9. Annual El Paso Cross-Border Truck Trips and Expected Annual FSS

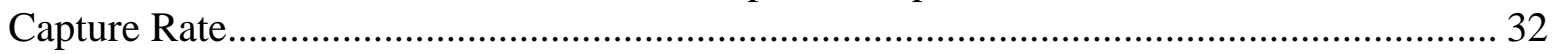

Table 10. Distances between the El Paso Industrial Areas and the Border Crossings

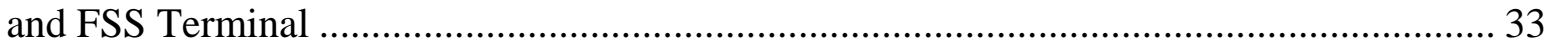

Table 11. Change in El Paso VMT with FSS Implementation ................................................... 34

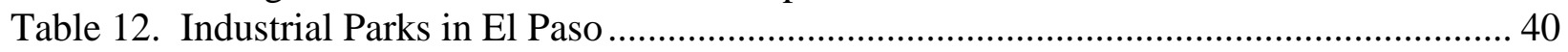

Table 13. Location of Industrial Parks per Cluster in El Paso...................................................... 41

Table 14. Industrial Parks in Ciudad Juarez. ............................................................................. 43

Table 15. Location of Industrial Parks per Cluster in Ciudad Juarez ............................................. 44

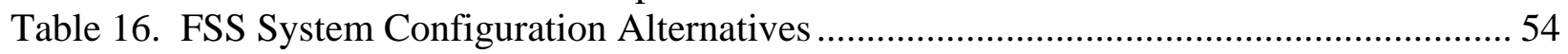

Table 17. Summary of the Presidential Permit Requirements ..................................................... 77

Table 18. Relevant State of Chihuahua State and Local Laws and Regulations ........................... 83

Table 19. U.S. Institutional Stakeholders in the Mexico-U.S. Border Crossing Process .............. 86

Table 20. Mexican Institutional Stakeholders in the Mexico-U.S. Border Crossing Process ..... 88

Table 21. Private Stakeholders in the Mexico-U.S. Border Crossing Process ............................... 90

Table 22. FSS Planning/Implementation Stage Stakeholder Map ............................................... 91

Table 23. FSS Operational Stage Stakeholder Map................................................................... 92

Table 24. Truck Emission Rates by Roadway Types ............................................................. 106

Table 25. Tons of Emissions for Current and FSS Operations ................................................. 106

Table 26. Summary of Travel Time, Idling, and Creep Idling .................................................. 107

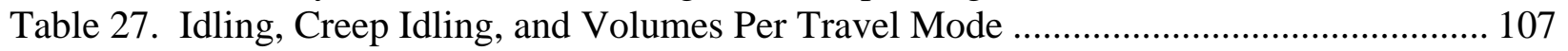

Table 28. Emission Rates for Idling and Creep Idling.......................................................... 108

Table 29. NOx Emissions Associated with Border Crossing Trips ............................................. 108

Table 30. Power Production Emission Inputs and Calculations .................................................. 109

Table 31. Calculated NOx Emissions Produced from Power Generation for............................. 110

Table 32. Summary of NOx Emission Changes with FSS Implementation ............................... 111

Table 33. Change in El Paso Diesel Fuel Consumed with FSS Implementation ...................... 112

Table 34. Total 10-mile FSS Economic Impact..................................................................... 113

Table 35. Summary of the Benefits Accrued by Implementing the FSS System ....................... 115

Table D1. FSS Annual Demand - Results from Monte Carlo Simulation (after Opening) .... 131 


\section{LIST OF BOXES}

Box 1: Mexico's Intersecretarial Group for Bridges and Border Crossings (CICSF)................ 81

Box 2: U.S. Institutions Involved in the Northbound Border Crossing Process......................... 85

Box 3: Mexican Institutions Involved in the Border Crossing Process .................................... 87

Box 4: Private Sector Stakeholders Involved in the Border Crossing Process........................... 89 
DISCLAIMER

This research was performed by the Center for International Intelligent Transportation Research, a part of the Texas Transportation Institute, in cooperation with Department of Energy. The contents of this report reflect the views of the authors, who are responsible for the facts and the accuracy of the data presented herein. 


\section{EXECUTIVE SUMMARY}

\section{THE PROBLEM: THE UNITED STATES LACKS A SUSTAINABLE FREIGHT TRANSPORTATION SYSTEM}

Currently, heavy-duty diesel trucks dominate intercity goods movement. Among the most appealing attributes of trucks is their inherent flexibility. They use existing infrastructure (the highway system) to reach dispersed and scattered customer and distribution locations. But the flexibility comes at a high cost: infrastructure deterioration, congestion, traffic safety issues, and pollution; The nation's transportation funding mechanism, fuel taxation and the highway trust fund, is

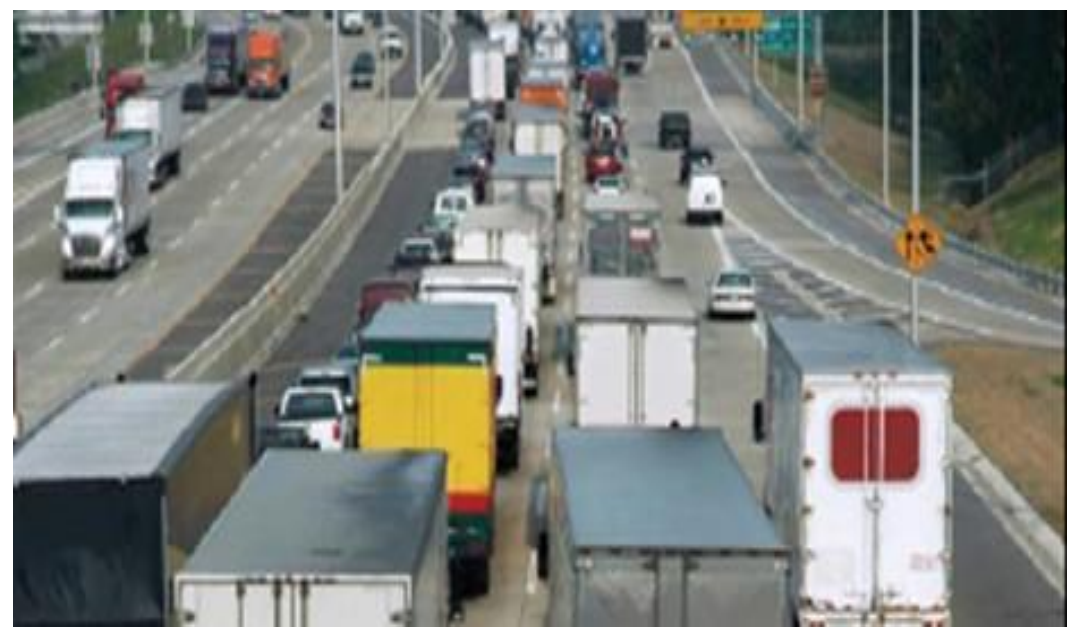
showing signs of distress and state departments of transportation are struggling with the over whelming dual burden of highway expansion to meet growing demand while maintaining the aging network that is already in place.

\section{THE SOLUTION: THE FREIGHT SHUTTLE SYSTEM}

The FSS is designed to provide freight transportation services between those short and intermediate distance locations (within 600 miles) that are currently handling large volumes of freight traffic. By borrowing features from both heavy-duty diesel trucks and railroads, the FSS is selfsustaining and more economical for shippers over the intercity distances that comprise a growing part of the goods movement

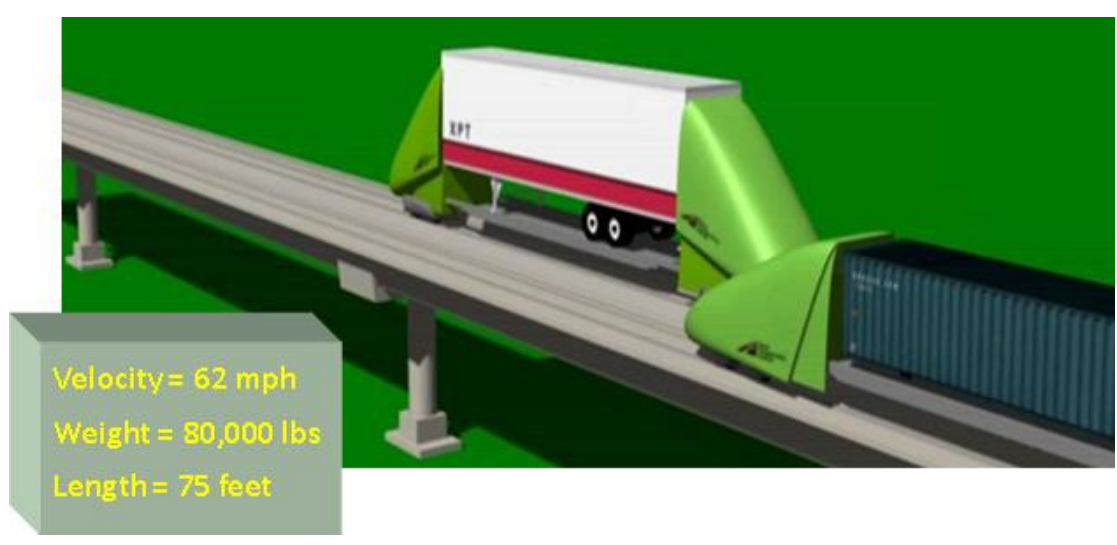
industry; Much like trucks, the FSS's transporters are autonomous: each transporter has its own propulsion and travels independently of other transporters. Inspired by railroads, each FSS transporter has steel wheels operating on a steel running surface and can carry either a standardsize freight container or an over-the-road truck trailer. However, unlike either rail or trucks, the FSS runs on an elevated, dedicated guideway to avoid the interference of other transportation systems. 
The FSS employs efficient, linear induction motors. Because these motors are electrically powered, the FSS will not add to existing pollution and will advance the US's effort to achieve energy independence and allow more environmentally friendly energy choices. Moreover, by taking unnecessary heavy-duty diesel truck traffic off the highway, the FSS indirectly reduces pollution and highway congestion, while improving traffic flow and safety.

\section{Freight Shuttle Business Model}

The FSS is being positioned as a privately owned and operated system; with today's costs, its business model indicates viability for traffic levels that represent just 15-20 percent of the trucks currently operating on heavily traveled commercial corridors. The FSS offers the opportunity to create a new kind of publicprivate partnership, predicated on creating value from underperforming highway airspace assets. The revenue earned from leasing airspace can, for example, be reinvested to maintain or expand the current highway system. Freight Shuttle International will license the right to use the Freight Shuttle technology in each specified geographic area to Licensee/Investor groups; The Licensee/Investor groups will finance the development of local Systems; the principals of

\section{FREIGHT SHUTTLE BUSINESS MODEL}

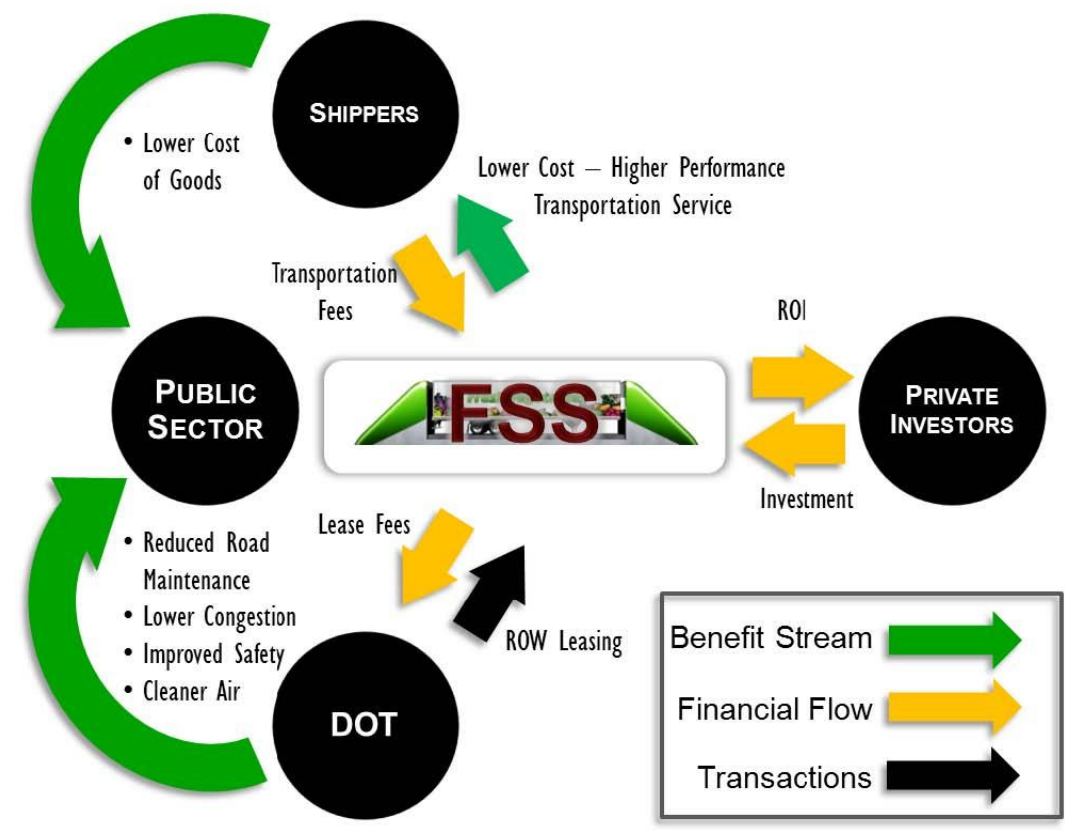

Freight Shuttle International have over 50 years of combined transportation, engineering and real estate development experience and will manage the development of local Systems. As currently envisioned, a national operating company, Freight Shuttle Operations, will manage the operations, maintenance, logistics, sales and customer support for all Freight Shuttle Systems. The FSS will generate revenue by selling customers guideway access, currently anticipated to be priced below current per mile trucking rates.

\section{Status of the Freight Shuttle}

The process of building and demonstrating a full-scale working prototype of the FSS is currently underway. The construction of the facility and demonstration of the prototype is projected to take 12-18 months. The early stages of prototyping have begun, including development team selection and the prototype planning process. Figg Engineering has designed the guideway. Trinity Industries is building the transporter along with Curtiss Wright, who has been selected to develop the propulsion package and the "intelligent" portions of the transporters - the linear induction system and all on-board electronics. Transdyne Corp has been selected to develop all communications, command, control systems and its parent company, Powell 
Industries will provide electrification services. Deaton Engineering has been selected to develop the mechanical switch, the guideway's dynamic element. These individual components will be integrated and demonstrated as a complete, full-scale operating System on the demonstration site. Several potential locations for the demonstration site have been identified and are currently being evaluated. The demonstration will result in a proven, commercially viable FSS.

\section{REPORT OBJECTIVE}

The major ports-of-entry (POE) to the US experience truck volumes during peak hours that are exceeding capacity; the El Paso-Ciudad Juarez POEs are no exception. Many historical challenges have prevented to achieve an efficient US-Mexico border crossing process: the existing border crossing and inspection processes are inefficient; the evolution of infrastructure for truck inspections has not kept pace with traffic volumes; September $11^{\text {th }}$ and the war on drugs in Mexico, particularly in Ciudad Juarez accompanied of its recent wave of terrorism, present many obstacles for efficient and secure transportation operations and inspections at the POEs. To make this problem worse, a significant amount of pollution is generated from the idling trucks waiting to cross the border decreasing the air quality in the region. Excessive waiting times affect commerce-especially freight by trucks.

Mexico is turning again as a more attractive trade partner for the US As proven during the time of spikes in oil prices in 2007 and more recently in 2011, transportation costs between the Pacific Rim and the US have become more significant; furthermore, the increasing labor costs, primarily in China, have made these inefficiencies more visible to many supply chain managers. As imports from Asia seem unsustainable for the long term, everything points to a shift in global commerce trends towards sourcing options near the US Recently, some firms have come back to the Americas establishing manufacturing operations closer to their consumption markets. Since Mexico is the closest and also an inexpensive sourcing option, added to its quality of gateway for commercial traffic coming from Asia, binational freight traffic is only expected to increase in the medium term between the US and Mexico.

This situation will be an increasing source of problems and an obstacle for efficient supply chain performance if nothing is done to provide an efficient system for cross-border movement of goods; eliminating any economic advantages that the short distance between US and Mexico could potentially offer.

The objective of this report is to examine the potential viability for an alternative transportation system for trailers and containers in a multi-national, cross-border setting. The El Paso-Ciudad Juarez region serves as the environment of this analysis.

\section{FSS DEMAND IN EL PASO}

The demand analysis first explores historical volumes and socioeconomic variables in order to project truck traffic out to 2043. Next, the dimensions or indicators of the current FSS market are developed from interviews of potential customers, and further used in a logit model to estimate the potential FSS traffic. Finally, the potential traffic demand for the FSS is evaluated in three inflationary scenarios to account for uncertainty. 
Utilizing this methodology, the total number of trips per year operated by the FSS for the three scenarios results in an estimated 650,000 trips per year in 2043 (see Figure ES-1).

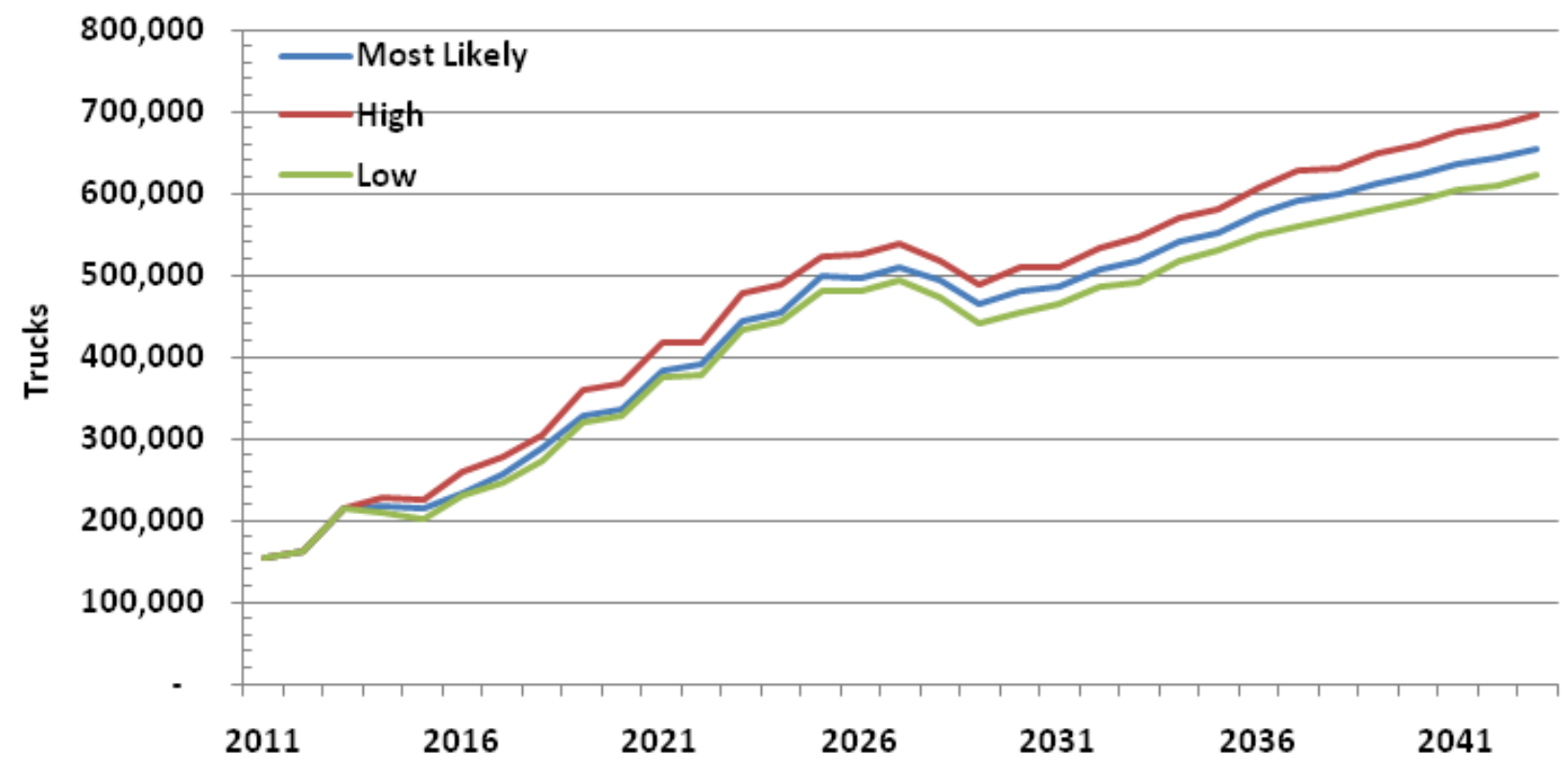

Figure ES-1. FSS Minimum, Maximum and Most Likely Market Capture

\section{CHANGES TO LOGISTICS PRACTICES IN EL PASO}

Current logistics practices in this area are driven by the Maquiladora industry. Maquiladoras are typically manufacturing operations that import components from the US, on a temporary basis, for assembly and subsequent export back to the US for final consumption. Since importation of goods is temporary, maquiladoras are often able to assemble goods and return them back to the US without paying a duty or tariff. Due to these tax incentives and the ability to garner cheaper labor rates, some US companies have strategically located themselves along the border. This strategic repositioning has imparted significant demand at border ports due to the required dray movements into and out of maquiladoras in Mexico.

The implementation of the FSS in this region would require the placement of inland terminals, on both sides of the border, in a strategic location that minimizes the distance to both industrial areas and Maquiladora clusters. The two inland terminals would be linked together by an elevated, dedicated guideway that runs nonstop through the border. This configuration will eliminate the need for dray movements that currently congest our nation's ports of entry.

\section{Change in Truck Vehicle Miles Traveled with FSS Implementation}

Currently, dray trucks travel between points in El Paso and Ciudad Juarez through one of the two major commercial truck international bridges. Implementation of the FSS integrates the transfer of those shipments in the FSS inland terminals where the cross-border movement is performed by the FSS. For this analysis, it is assumed the system will consist of a 10-mile cross- 
border system with terminals located five miles from the border on each side at the Zaragoza Bridge.

The approach consists of calculating the change in vehicle miles traveled based on replacing a calculated level of truck trips between major industrial areas and the Bridge of the Americas (BOTA) and Zaragoza with truck trips to and from a FSS terminal. The results show that in the first year of evaluation, 2014, there would a reduction in VMT of over eight percent, with steady growth to a reduction of over 22 percent in 2037 as more of the cross-border trips are captured by the FSS.

\section{BENEFITS OF THE FSS IN EL PASO}

It is expected that implementation of the FSS will provide a wide range of benefits to the region, maquiladoras and shippers.

\section{Air Quality Benefits}

Calculating the emissions related with truck operations involved in cross-border movements that use the FSS includes calculating the emissions from trucks during transport; emissions from trucks delayed at the existing border crossing facilities; and emissions from power generation to power the FSS electric transporters.

\section{Truck Emissions}

The truck VMT calculations provide the foundation for calculating the emissions related to transporting good across the border in El Paso. Table ES-1 shows the tons of emissions produced by cross-border trips by emission types over the entire 24-year evaluation period. The implementation of the FSS will eliminate almost 87,000 tons of pollutants over the analysis period. The nitrogen oxides (NOx) emission factor is often discussed in areas of air quality concerns, such as El Paso. The table shows that the quantity NOx would be reduced by over 446 tons with the implementation of the FSS.

Table ES-1. Tons of Emissions for Current and FSS Operations Based on VMT

\begin{tabular}{|c|c|c|c|}
\hline Emission Type & Tons Current & Tons FSS & Difference (tons) \\
\hline VOC & 143.2 & 123.0 & -20.2 \\
\hline CO & 612.3 & 526.0 & -86.3 \\
\hline NOx & $3,169.1$ & $2,722.5$ & -446.6 \\
\hline PM-10 & 63.8 & 54.8 & -9.0 \\
\hline CO2 & $612,924.6$ & $526,547.7$ & $-86,376.9$ \\
\hline Total & $\mathbf{6 1 6 , 9 1 3 . 0}$ & $\mathbf{5 2 9 , 9 7 4 . 0}$ & $\mathbf{- 8 6 , 9 3 9 . 0}$ \\
\hline
\end{tabular}

\section{Border Crossings}

One of the existing conditions facing the border is the significant delay to commercial vehicles attempting to make shipments between Mexico and the US. Focusing on NOx emission levels, the FSS is expected to eliminate over 278 tons of NOx emissions in the El Paso region. 


\section{Power Generation}

The FSS consists of an electrically driven transporter. The increased electricity generated to operate the energy efficient system is calculated to only produce 29 tons of NOx emissions over the 24-year analysis period. Since the system is electrically operated, it is expected that green technologies, such as solar and/or wind, could be used to generate the power necessary to operate the system.

\section{Combined Emission Analysis}

The FSS results in a total reduction of almost 696 tons of NOx emissions in El Paso over the 14-year period, which translates into almost a 23 percent reduction in the final year. The associated elimination of NOx emissions provides a monetary benefit to the region of over $\$ 3.8$ million for the 24-year analysis period.

\section{Reduction in Diesel Consumption}

Many of the benefits are related to the reduced VMT attributed to the FSS. A portion of the trucks that would have otherwise driven to the border crossing would travel to the FSS terminal, located a short distance from the border crossing. Considering only the El Paso portion of the trip a reduction of over 47.9 million VMT over the 24 years would result from implementing the FSS. This equates to the reduced consumption of approximately 7.5 million gallons of diesel fuel.

\section{Border Crossing Delay - Trucking Savings}

Using the calculated delay times at the border crossings at each segment of the border crossing process, the overall delay is calculated for the levels of trucks currently crossing the border crossings and the levels of trucks that would instead utilize the FSS. Over the 24-year analysis period there would be a reduction of over 3.1 million hours of delay. Considering a value of time for trucking of $\$ 76.29$ per hour, the calculated Net Present Value (NPV) for avoided delay is $\$ 102$ million.

\section{Economic Impacts and Job Creation}

It is well established that undertaking infrastructure projects provides positive economic impacts. In an effort to stimulate the economy, the US federal government implemented several competitive grant programs for transportation infrastructure projects. As with other major infrastructure projects, constructing the FSS will provide positive economic impacts in the El Paso region. Economic impacts will result from the one-time construction of the system, along with ongoing operations of the system. Table ES-2 shows the positive economic impacts associated with the 10-mile FSS proposed for the El Paso region would approach $\$ 2$ billion over the life of the project. Additionally, the US federal government estimates that for every $\$ 92,000$ expended on the project, one job-year will be created. For this project, the number of calculated job-years created is equal to 2,206 job-years. 
Table ES-2. Total 10-mile FSS Economic Impact

\begin{tabular}{|c|c|}
\hline Expenditure Type & Economic Impact \\
\hline One Time Construction & $\$ 399,895,432$ \\
\hline Ongoing & $\$ 1,598,493,385$ \\
\hline Total Economic Impact & $\$ 1,998,388,818$ \\
\hline
\end{tabular}

\section{Partnerships}

With the FSS, there is unilateral support for the construction of the FSS at the existing Ysleta-Zaragoza Port of Entry. With this unanimous support, the regulatory hurdles are largely minimized and should result in the ability to amend the existing treaty in order to support the construction of the FSS either on or adjacent to the existing Ysleta-Zaragoza Port of Entry bridge structures.

\section{Livability}

Examining the freight terminal and warehousing activities in El Paso and Ciudad Juarez shows steady growth of these facilities throughout the entire region. In El Paso large clusters of industrial areas exist and could provide a good location for the FSS terminal location. The FSS terminal will act as a major attractor of truck movements. Locating the terminal within or close to an already existing or planned industrial area reduces the length of truck trips on the region's highways. Additionally, the terminal will provide economic development opportunities for compatible industrial development adjacent to the terminal. This consolidation and/or development of freight activities around the FSS terminal supports economic development, reduces the truck trips throughout the region, improves safety, and improves the air quality in the region.

\section{Security}

International trade is an important part of the nation's economy. Our North American trading partners, Canada and Mexico, are both consumers of US products and suppliers of goods and material to American firms and to the public. The level of trade between the US and these neighbors to the north and south is impacted by both economic/political considerations and by the overriding need to ensure the safety and security of our country. International borders are the last lines for our national security programs and critical to ensure the integrity of international relationships and commerce. September $11^{\text {th }}$ and the drug-war in Mexico have elevated the mission of Customs and Border Protection (CBP) to an incredibly difficult-to-achieve level. Maintaining or increasing trade levels and ensuring security (of CBP personnel and US citizens) is more challenging than ever and hence, new tools and new strategies are needed to succeed.

While the Freight Shuttle is designed with congested domestic corridors as its primary focus, the system has features that lend themselves to international trade/cross border settings and facilitating the mission of CBP. The system will inspect 100 percent of the cargo through the system utilizing a method called Inspect-in-Motion. The Inspect-in-Motion facilitates the mission of CBP and reduces many of the challenges associated with today's international trade 
environment. The features of the Freight Shuttle that have been identified as lending themselves to enhancing the safety and security of cross-border operations include:

1. The system is automated and has no on-board driver.

2. The system operates over a dedicated, elevated, grade separated guideway exclusively between specified locations.

3. Shipments are timed to be non-stop movements between terminal locations.

4. The system's constant high velocity lends itself to improved security.

5. The system is being developed in accordance with all C-TPAT (CustomsTrade Partnership Against Terrorism) policies and procedures.

6. The system pushes cargo examination outward, and reduces the risk of contraband entering the US.

7. The system allows for a full NII (Non-Intrusive Inspection) examination to be conducted and a "Go or No Go" order to be issued by CBP, similar to what now happens with the CSI (Container Security Initiative).

These characteristics, if implemented in the proper international trade settings, can be used to overcome many of the challenges facing CBP in accomplishing its mission. The Inspect-inMotion concept is being developed as a means to increase inspection rates to 100 percent and mitigate the risks associated with the current procedures and standards of inspection. The system has the potential to move the inspection process away from congested border locations and automate many of the activities now performed by CBP personnel.

\section{Benefits Review}

Benefits associated with the implementation of the FSS would accrue to the region, maquiladoras and shippers. Implementing the FSS would reduce the emissions from trucks traveling to the border crossings and waiting at the border inspection/processing facilities. The reduced waiting at the border crossing facilities also will save the consumption of diesel. Additionally, significant positive economic impacts will accrue from the construction and continued operation of the system, including the creation of jobs for the region. Table ES-3 summarizes the calculated benefits.

Table ES-3. Summary of the Benefits Accrued by Implementing the FSS

\begin{tabular}{|c|c|}
\hline Benefit & $\boldsymbol{N P V}$ \\
\hline Emissions & $\$ 3,802,164$ \\
\hline Border Delay & $\$ 102,277,820$ \\
\hline Economic Impact & $\$ 1,998,388,818$ \\
\hline Benefit & Value \\
\hline Diesel Fuel Saved & $7,499,522$ gallons \\
\hline Job-Years Created & 2,206 job-years \\
\hline
\end{tabular}




\section{CHAPTER 1:}

\section{INTRODUCTION}

\subsection{BACKGROUND}

The major ports-of-entry (POE) to the U.S. experience truck volumes during peak hours that are exceeding capacity; the El Paso-Ciudad Juarez POEs are no exception. Many historical challenges have prevented to achieve an efficient U.S. - Mexico border crossing process: the existing border crossing and inspection processes are inefficient; the evolution of infrastructure for truck inspections has not kept pace with traffic volumes; September $11^{\text {th }}$ and the war on drugs in Mexico, particularly in Ciudad Juarez accompanied of its recent wave of terrorism, present many obstacles for efficient and secure transportation operations and inspections at the POEs. To make this problem worse, a significant amount of pollution is generated from the idling trucks waiting to cross the border decreasing the air quality in the region. Excessive waiting times affect commerce - especially freight by trucks since their approximate value of time is US $\$ 40$ per hour of delay.

Mexico is turning again as a more attractive trade partner for the U.S. As proven during the time of spikes in oil prices in 2007 and more recently in 2011, transportation costs between the Pacific Rim and the U.S. have become more significant; furthermore, the increasing labor costs, primarily in China, have made these inefficiencies more visible to many supply chain managers. As imports from Asia seem unsustainable for the long term, everything points to a shift in global commerce trends towards sourcing options near the U.S. Recently, some firms have come back to the Americas establishing manufacturing operations closer to their consumption markets. Since Mexico is the closest and also an inexpensive sourcing option, added to its quality of gateway for commercial traffic coming from Asia, binational freight traffic is only expected to increase in the medium term between the U.S. and Mexico.

This situation will be an increasing source of problems and an obstacle for efficient supply chain performance if nothing is done to provide an efficient system for cross-border movement of goods; eliminating any economic advantages that the short distance between U.S. and Mexico could potentially offer.

Designed to improve supply chain performance, the Freight Shuttle System (FSS) is an automated system of guideways, transporters, and terminals intended to move intermodal containers or truck trailers. Freight Shuttle International LLC, (FSI) owns the exclusive right to license the FSS technology developed in the Texas Transportation Institute (TTI). FSI's business model considers that groups of licensees and investors will finance the development of local systems; furthermore, FSI will manage the development of such systems through a subsidiary company. As an innovative alternative for a more efficient movement of goods across the border, TTI's Center for International Intelligent Transportation research (CIITR) is exploring the applicability of the FSS concept in the El Paso-Ciudad Juarez region. 
The Freight Shuttle System is an innovative new mode of freight transportation that is designed using existing, proven technology. It will move trailers and containers, via automated transporters, over distances of 5 to 500 miles on an emission-free, electric-powered guideway system, constructed on existing highway rights-of-way.

The Texas Transportation Institute (TTI) has developed a new freight transportation mode: the Freight Shuttle System (FSS). The FSS was conceived to resolve freight transportation's most pressing deficiencies: congestion and managing uncertainty, productivity and the need for capacity improvements, driver shortages, energy costs and the prospect of fuel shortages, air quality issues and government regulation that cancels out improvements in engine efficiency and highway safety and risk management issues.

\section{The Problem: The U.S. Lacks a Sustainable Freight Transportation System}

Currently, heavy-duty diesel trucks dominate intercity goods movement. Among the most appealing attributes of trucks is their inherent flexibility. They use existing infrastructure (the highway system) to reach dispersed and scattered customer and distribution locations. But the flexibility comes at a high cost: infrastructure deterioration, congestion, traffic safety issues, and pollution; The nation's transportation funding mechanism, fuel taxation and the highway trust fund, is showing signs of distress and state departments of transportation are struggling with the over whelming dual burden of highway expansion to meet growing demand

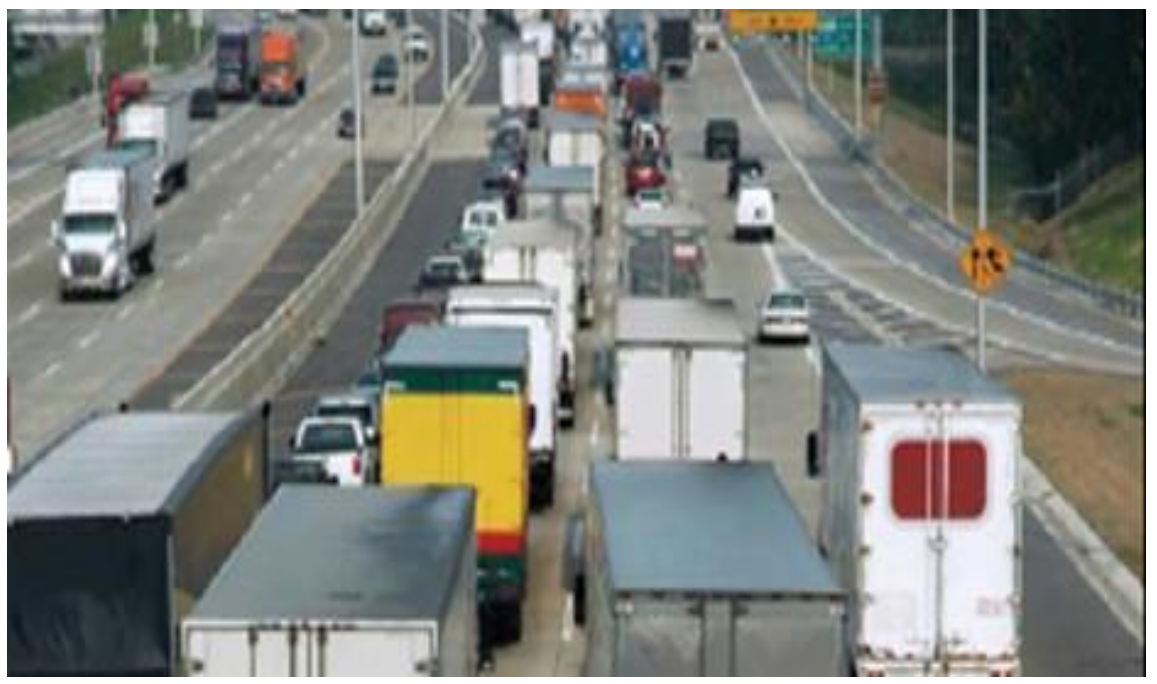
while maintaining the aging network that is already in place.

\section{The Solution: The Freight Shuttle System}

The FSS is designed to provide freight transportation services between those short and intermediate distance locations (within 600 miles) that are currently handling large volumes of freight traffic. By borrowing features from both heavy-duty diesel trucks and railroads, the FSS is selfsustaining and more economical for shippers over the intercity distances that comprise a growing part of the goods movement industry; Much like trucks, the FSS's transporters are autonomous: each transporter has its own propulsion and travels independently of other transporters. Inspired by railroads, each FSS transporter has steel wheels operating on a steel running surface and can carry either a standard-size freight container or an over-the-road truck trailer. However, unlike either rail or trucks, the FSS runs on an elevated, dedicated guideway to avoid the interference of other transportation systems. 
The FSS employs efficient, linear induction motors. Because these motors are electrically powered, the FSS will not add to existing pollution and will advance the U.S.'s effort to achieve energy independence and allow more environmentally friendly energy choices. Moreover, by taking unnecessary heavy-duty diesel truck traffic off the highway, the FSS indirectly reduces pollution and highway congestion, while improving traffic flow and safety.

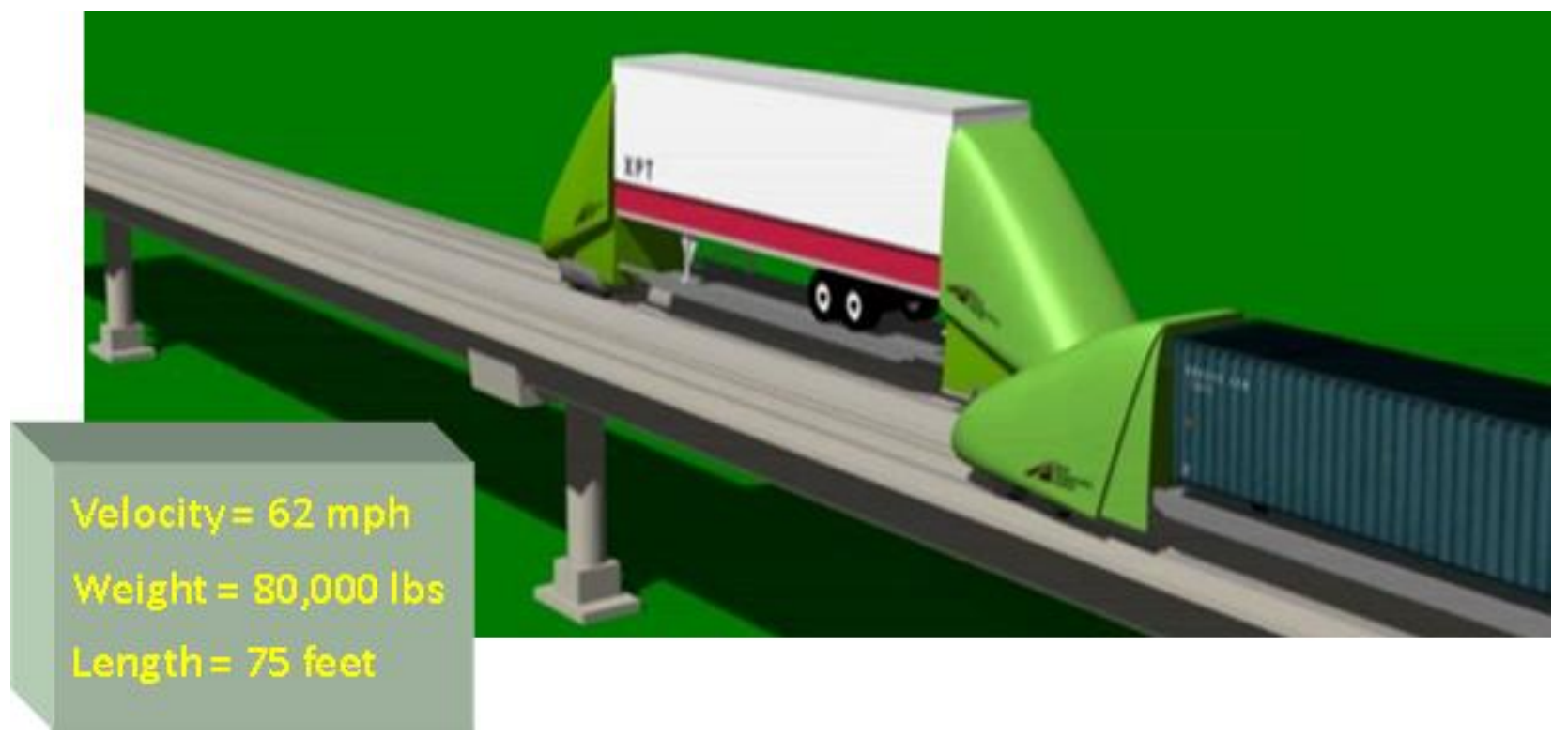

Freight Shuttle transporters operating on elevated, bi-directional guideway.

\section{FREIGHT SHUTTLE TECHNOLOGY}

The FSS concept has been developed and designed over the last seven years at TTI, and is now being commercialized for use in Texas. The System is composed of three primary components: transporters, guideways and terminals. These components are linked together by an intelligent communications, command, and control system (C3). Single unit transporters are designed to move cargo to and from terminals via an elevated, electric powered guideway system. Transporters straddle a vertical guideway component, positioned perpendicular to the running surface (along the length of the guideway), that will power and steer the transporters. Transporters and guideways are designed to interlock in order to prevent unintended transporter/guideway

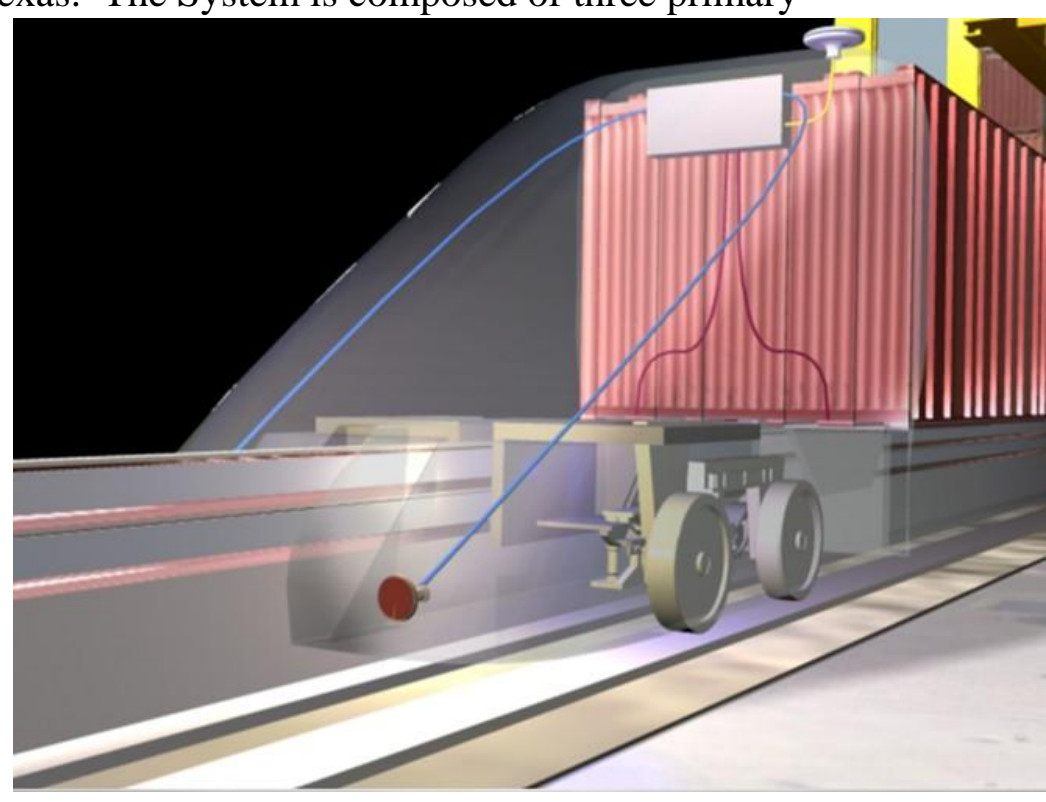

Designed to take advantage of the low rolling resistance of steel wheels on a steel running surface 
separation. Guideways are designed with a small footprint to facilitate placement within existing transportation right-of-ways and to allow significant flexibility in designing alignments.

The guideway's footprint is designed to be only 4-6 feet in width (the area for individual support pillars), which will enable the System to make use of narrow existing ROW, such as a

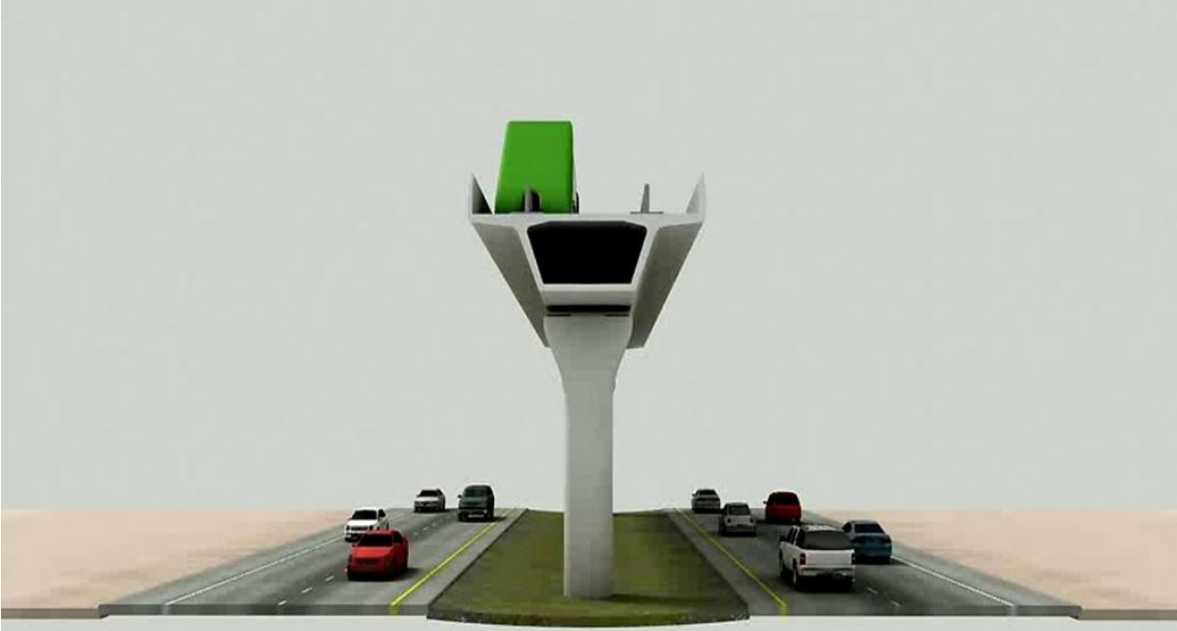

FSS operates on its own dedicated guideway system within the existing transportation rights-of-ways. highway median, for example, eliminating the need to acquire any new ROW. The design will reduce potential property conflicts and should therefore decrease the time needed to obtain approvals. A dedicated guideway also enables automation because passenger traffic and pedestrians will have no interaction with the System. The guideway is designed for modular, prefabricated construction, a key feature that will dramatically lower construction costs. This design will enable rapid construction and enable most of the building process to be completed from the guideway itself, greatly limiting the impact on traffic in the active lanes below the guideway.

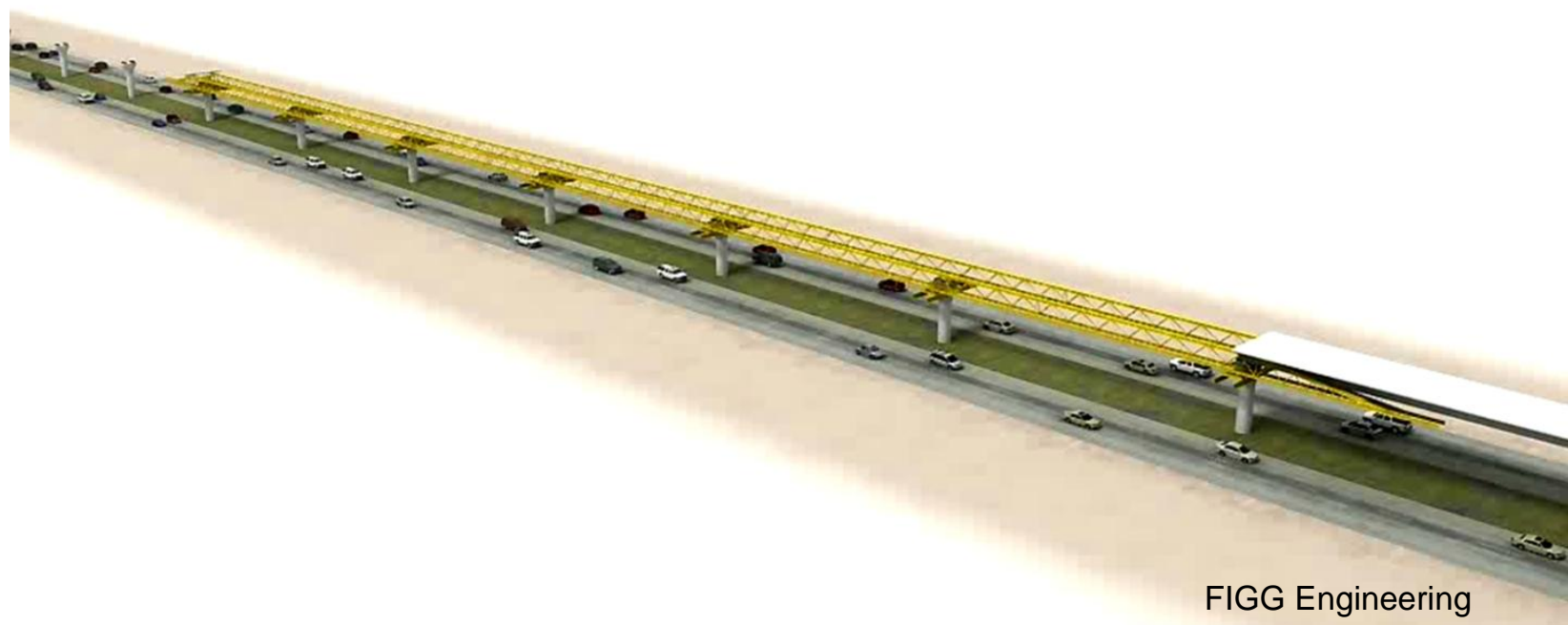


The transporters, best characterized as driverless electric trucks, are engineered to be fully automated and move along the guideway individually (as opposed to building "trains"); they are designed to accommodate either containers or trailers to minimize the need to reconfigure freight loads within the terminal prior to departure. For applications where it is relevant, FSI has also designed the transporters to operate with a rotating cargo bay that allows trailers to be driven directly onto and off of the transporter. Containers (and some truck trailers), on the other hand, can be lifted onto the transporters using standard overhead cranes.

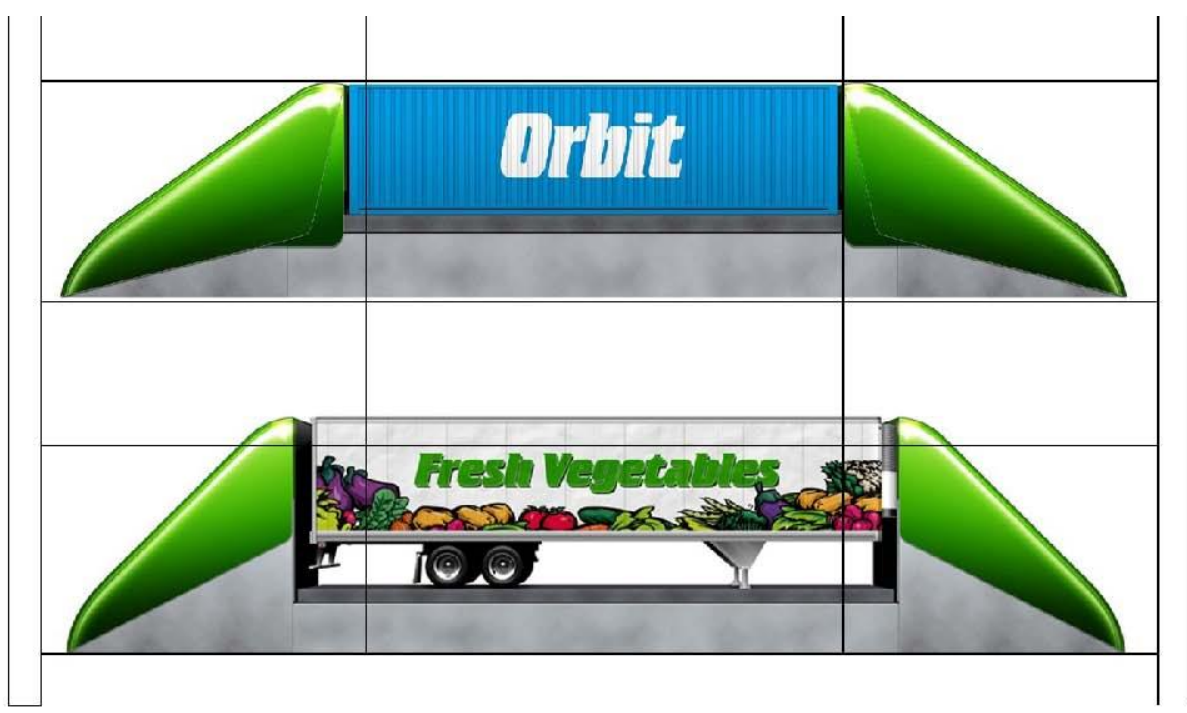

Transporters can haul trailers or containers.

View of transporter swivel system allows trucks to pickup (drop-off) trailers directly from (onto) transporter.
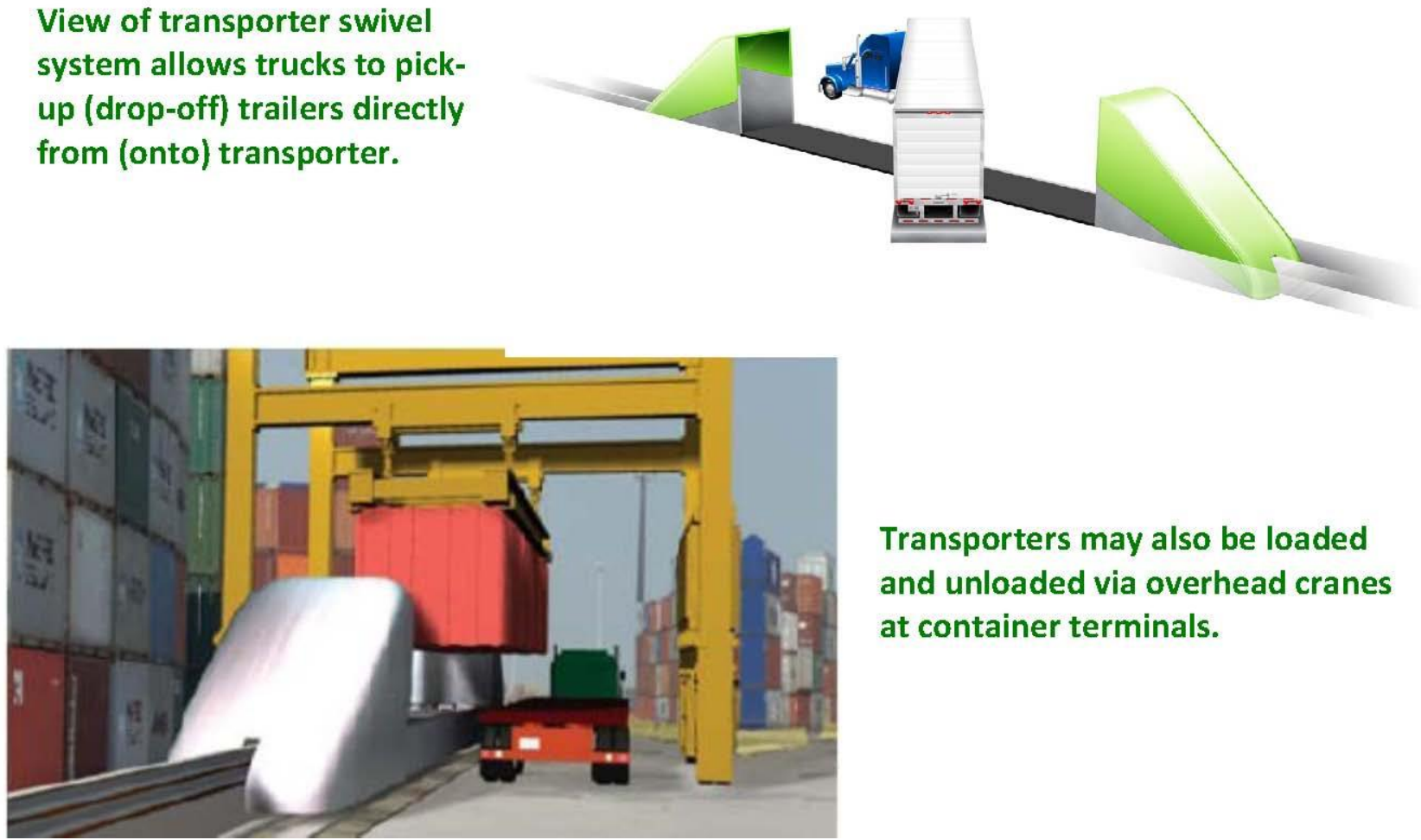

Transporters may also be loaded and unloaded via overhead cranes at container terminals. 


\section{FREIGHT SHUTTLE BUSINESS MODEL}

The FSS is being positioned as a privately owned and operated system; with today's costs, its business model indicates viability for traffic levels that represent just $15-20$ percent of the trucks currently operating on heavily traveled commercial corridors. The FSS offers the opportunity to create a new kind of public-private partnership, predicated on creating value from under-performing highway airspace assets. The revenue earned from leasing airspace can, for example, be reinvested to maintain or expand the current highway system. Freight Shuttle International will license the right to use the Freight Shuttle technology in each specified geographic area to Licensee/Investor groups; The Licensee/Investor groups will finance the development of local Systems; the principals of Freight Shuttle International have over 50 years of

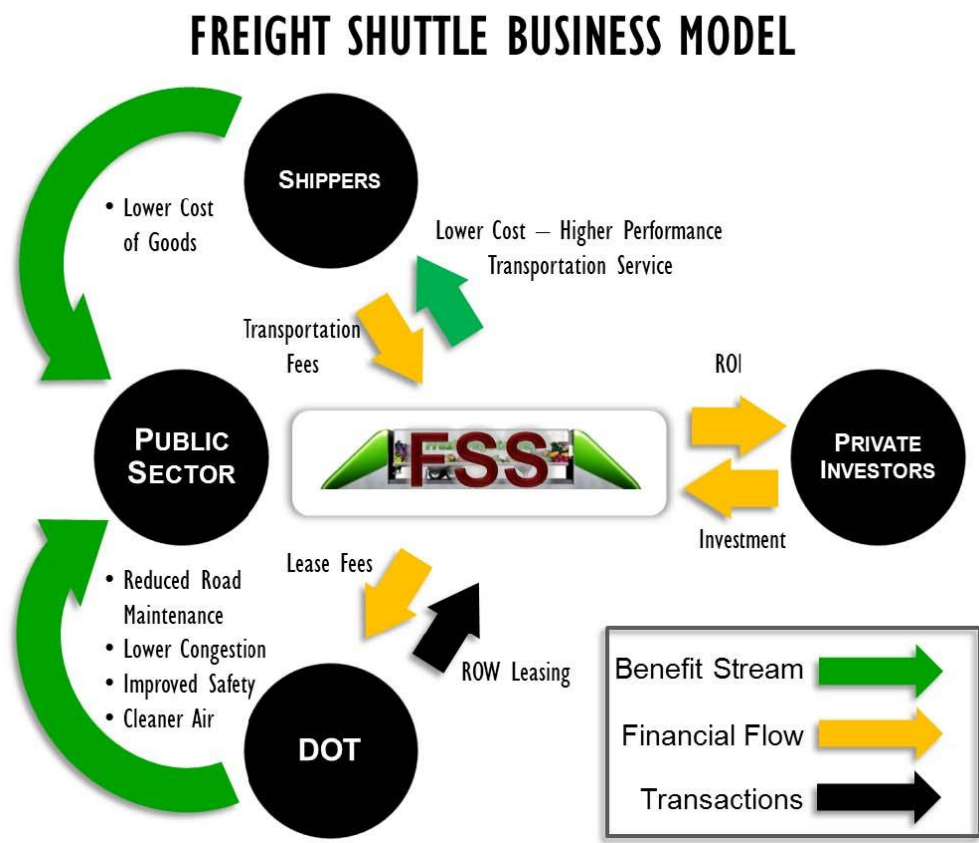
combined transportation, engineering and real estate development experience and will manage the development of local Systems. As currently envisioned, a national operating company, Freight Shuttle Operations, will manage the operations, maintenance, logistics, sales and customer support for all Freight Shuttle Systems. The FSS will generate revenue by selling customers guideway access, currently anticipated to be priced below current per mile trucking rates.

\section{STATUS OF THE FREIGHT SHUTTLE}

On April 8, 2011, the Texas Department of Transportation (TxDOT) disseminated a request for competing proposals "For the Lease of TxDOT-owned Right-of-way to Implement Low Emission Freight Transportation Facilities." This proposal opens up billions of dollars in TxDOT-owned highway rights of way to use by the private sector for dedicated goods movement. Coupling proven technology and an innovative business model with a world class investment bank, the FSS is in the perfect position to respond to TxDOT's RFP. Up to two projects will be pursued in this first proposal, one in El Paso and the second along the freight backbone of Texas - I-35, the first segment being a 275 mile system from Dallas to San Antonio.

The process of building and demonstrating a full-scale working prototype of the FSS is currently underway. The construction of the facility and demonstration of the prototype is projected to take 12-18 months. The early stages of prototyping have begun, including development team selection and the prototype planning process. Figg Engineering has designed the guideway. Trinity Industries is building the transporter along with Curtiss Wright, who has 
been selected to develop the propulsion package and the "intelligent" portions of the transporters - the linear induction system and all on-board electronics. Transdyne Corp has been selected to develop all communications, command, control systems and its parent company, Powell Industries will provide electrification services. Deaton Engineering has been selected to develop the mechanical switch, the guideway's dynamic element. These individual components will be integrated and demonstrated as a complete, full-scale operating System on the demonstration site. Several potential locations for the demonstration site have been identified and are currently being evaluated. The demonstration will result in a proven, commercially viable FSS.

\subsection{OBJECTIVE}

The objective of this report is to examine the potential viability for an alternative transportation system for trailers and containers in a multi-national, cross-border setting.

This report aims to expose the strengths and weaknesses of the FSS proposed venture, as well as opportunities and threats as presented by the environment for binational implementation. It attempts to illustrate the resources required for implementation and ultimately identify the prospects for success.

This study aims to serve as a roadmap for technical development and project implementation in the El Paso - Ciudad Juarez region and as a framework for implementation in other U.S. Mexico borders.

\subsection{OUTLINE OF THE REPORT}

The present document is the result of research performed on eight major tasks concluding in the following Chapters:

- Chapter 1. Introduction. Provides the introduction to this research, explains the problem and the need to explore it, and presents the objective of this report as a solution to the problem.

- Chapter 2. Cross-Border Container Moves-Demand Analysis. Estimates the potential FSS border crossing traffic. First, it explores historical volumes and socioeconomics; subsequently, truck traffic projections are developed. The dimensions of the current FSS market were developed from interviews of potential customers, and further used in a logit model to estimate the potential FSS traffic. Finally, three scenarios are developed to account for uncertainty.

- Chapter 3. Changes to Logistics Practices. Examines the current logistics practices to assess the changes required for shipments to emanate a centralized, government-operated inspections terminal. The evaluation includes an assessment of the vehicle miles traveled (VMT) savings, based on the potential routes, which could accrue with a well place inland terminal. 
- Chapter 4. Terminals and Border Crossing Target Locations. Outlays a possible configuration of a binational system in the Ciudad Juarez - El Paso region. Explores terminal location alternatives first in El Paso, and then in Ciudad Juarez by identifying existent industrial clusters, available land, regional growth and development plans, and available infrastructure at the POEs. It concludes with the configuration of the possible routes for the system.

- Chapter 5. Analysis of Regulatory and Institutional Frameworks, and Assessment of Management Models. Assesses possible institutional, operational, and governance models for the binational FSS system. For this, a stakeholder analysis is performed for the commercial border crossing process, and a binational model for operations is proposed. In addition, the US-Mexico regulatory framework is documented aiming to gather requirements and possible legal challenges for binational implementation. This chapter concludes with a proposed binational business management structure for implementation.

- Chapter 6. Assessment of Security and Power Usage. This chapter presents assessments of the security considerations of cross-border movements utilizing the FSS system and the power usage of the system.

- Chapter 7. Benefits Review. This chapter presents assessments of the security considerations of cross-border movements utilizing the FSS system and the power usage of the system. 


\section{CHAPTER 2:}

\section{CROSS-BORDER CONTAINER MOVES-DEMAND ANALYSIS}

\subsection{OVERVIEW}

This chapter presents the demand analysis and forecast for the potential FSS traffic. First, it explores historical volumes and socioeconomic variables; subsequently, truck traffic projections are developed. The dimensions or indicators of the current FSS market were developed from interviews of potential customers, and further used in a logit model to estimate the potential FSS traffic. Finally, the potential traffic demand for the FSS is evaluated in three inflationary scenarios to account for uncertainty.

This chapter consists of the following sections:

2.2 Methodology. This section describes the steps followed to estimate the potential demand for the FSS. Two simultaneous methodologies were combined to indicate the expected number of trips operated by the FSS in the next thirty years.

2.3 Truck Traffic Projections. This section describes data collected and which data proved to be statistically significant to forecast trucks crossing volumes. It presents the approach used to forecast cross-border trucks traffic projections including northbound and southbound traffic.

2.4 Receptivity of Regional Shippers. This section presents a market analysis exploring current and future receptivity of the FSS services, and aims to identify customer preferences to define the market dimensions or indicators. Such indicators are further used in a model used to forecast probabilities for potential FSS market capture rates. Finally, it explains the scenario development and their main differences.

2.5 Potential FSS Traffic. This section estimates the potential FSS cross-border container moves (i.e. total number of potential trips per year operated by the FSS). Three scenarios are presented based on the FSS market capture rates.

2.6 Chapter Summary and Recommendations. This section summarizes the findings and conclusions of each section, and provides recommendations.

\subsection{METHODOLOGY}

In order to estimate the number of border crossing trips that the FSS would capture, two simultaneous processes were necessary (see Figure 1). First it was needed to assess the total market size, in other words, the total number of trucks crossing the border in both directions every year. An autoregressive integrated with moving averages (ARIMA) model was the preferred method to forecast tuck crossing. The historical data on truck crossings was obtained from the Bureau of Transportation Statistics (BTS) up to the year 2009. The U.S. Gross Domestic Product (GDP) served as explanatory variable. Once the ARIMA was evaluated, 
expected truck border crossing volumes between El Paso and Ciudad Juarez were obtained for each year up to 2043 .

In order to estimate the degree of receptivity that regional shippers would have towards a new border crossing mode such as the FSS, a total of 53 surveys were conducted among the local maquiladoras; the shipments of these maquiladoras represented $15 \%$ of all truck crossings, which guaranteed statistical significance for this exercise. Although all variables produced by the survey were evaluated, only six proved to be valuable in order to estimate demand probability:

- number of current hired carriers;

- ability to reschedule or spread the shipments through the day;

- current cost or price charged by carriers;

- the price that shippers are willing to pay for the new mode; and

- two qualitative attributes of the FSS.

In order to calculate future probabilities, the cost and price related explanatory variables were forecasted using three inflationary scenarios. An ARIMA model was applied for this task. The results were three sets of explanatory variables for the years 2010 to 2043. With these explanatory variables, new probabilities were estimated for the upcoming years. The result was 99 probabilities (i.e. one for each of the 33 forecasted years in three inflationary scenarios). Finally, each demand probability was evaluated against the expected traffic volumes, to produce the expected number of trips operated by the FSS from 2011 to 2043 in three scenarios.

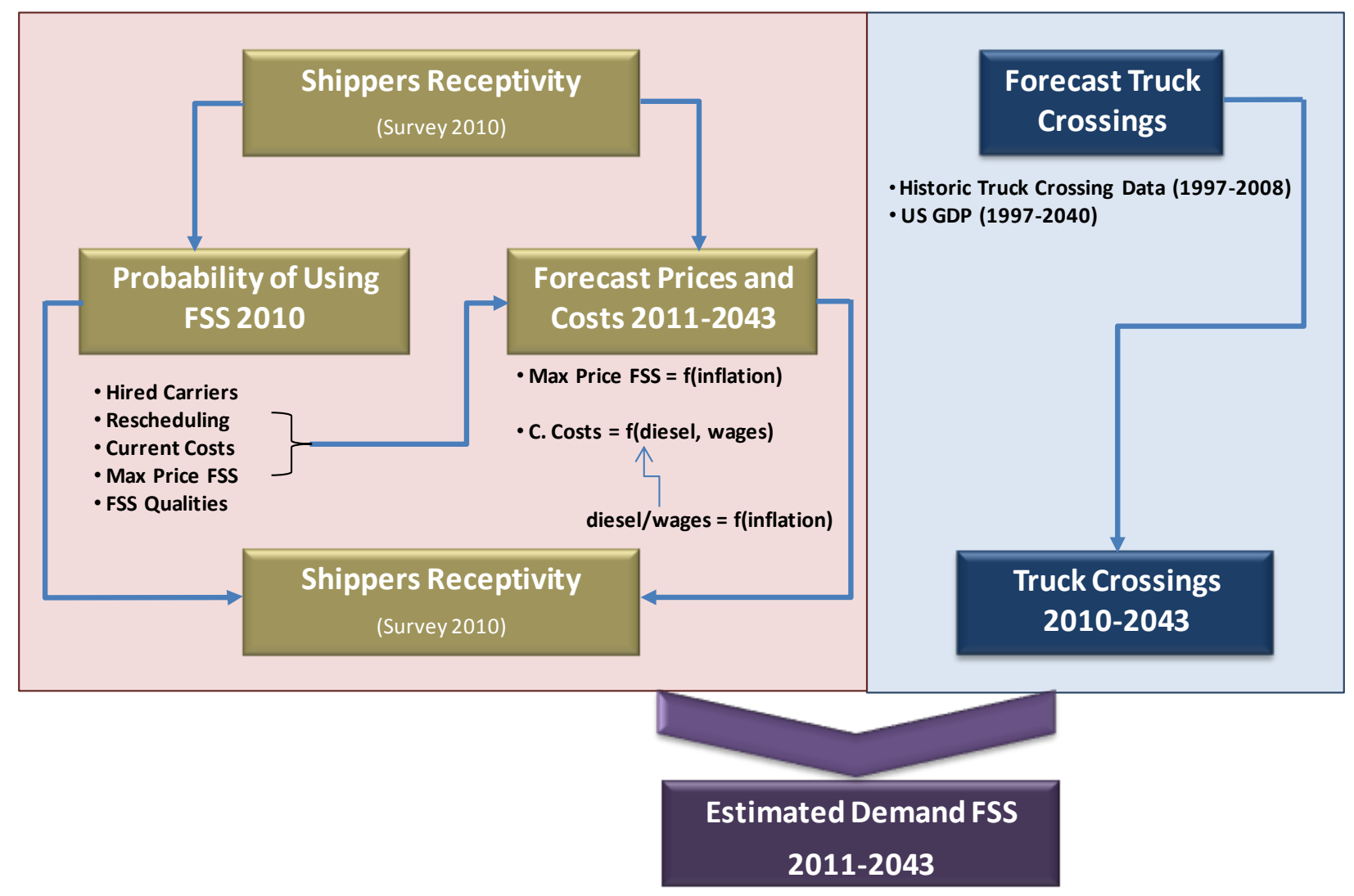

Figure 1. Methodology for the FSS Demand Analysis 


\subsection{TRUCK TRAFFIC PROJECTIONS}

\section{Data Collected}

Historical data on truck crossings obtained from BTS was used to estimate future demand for the FSS. The first step was to estimate the border crossing truck traffic projections for both southbound and northbound trips. Several data series where assessed to determine the best fit, these include: historical border crossing truck volumes, GDP for the U.S. and Mexico, Gross Metropolitan Product (GMP) for El Paso and Ciudad Juarez, the number of maquiladoras operating in Ciudad Juarez, and the USD - MEX exchange rate. The data series assessment revealed that only the U.S. GDP proved to be statistically significant to forecast truck crossing volumes.

Historical border crossing truck volumes increased steadily between 1996 and 2007, with an average annual growth rate of 2.5 percent; however, border crossing truck traffic dropped more than 14 percent between 2007 and 2009 when Maquiladora activity decreased due to the global economic crisis (see Table 1).

Table 1. Historical Truck/Container Volumes

\begin{tabular}{|c|c|c|c|c|c|c|c|}
\hline Year & $\mathbf{1 9 9 6}$ & $\mathbf{1 9 9 7}$ & $\mathbf{1 9 9 8}$ & $\mathbf{1 9 9 9}$ & $\mathbf{2 0 0 0}$ & $\mathbf{2 0 0 1}$ & $\mathbf{2 0 0 2}$ \\
\hline Containers & 801,646 & 839,950 & 873,497 & 970,108 & $1,038,438$ & 952,205 & $1,016,517$ \\
\hline Year & $\mathbf{2 0 0 3}$ & $\mathbf{2 0 0 4}$ & $\mathbf{2 0 0 5}$ & $\mathbf{2 0 0 6}$ & $\mathbf{2 0 0 7}$ & $\mathbf{2 0 0 8}$ & $\mathbf{2 0 0 9}$ \\
\hline Containers & 950,808 & $1,037,197$ & $1,067,625$ & 1,073, & $1,128,572$ & $1,093,862$ & 917,671 \\
\hline \multicolumn{2}{r}{ Source: Bureau of Transportation Statistics (BTS) }
\end{tabular}

According to the Bureau of Economic Analysis (BEA), the U.S. GDP shows a similarly increasing pattern; however, 2009 exhibits a less accelerated growth rate (see Table 2).

Table 2. Historical US GDP (billions of USD)

\begin{tabular}{|c|c|c|c|c|c|c|c|}
\hline Year & $\mathbf{1 9 9 6}$ & $\mathbf{1 9 9 7}$ & $\mathbf{1 9 9 8}$ & $\mathbf{1 9 9 9}$ & $\mathbf{2 0 0 0}$ & $\mathbf{2 0 0 1}$ & $\mathbf{2 0 0 2}$ \\
\hline GDP & 31,354 & 33,329 & 35,174 & 37,414 & 39,806 & 41,145 & 42,569 \\
\hline Year & $\mathbf{2 0 0 3}$ & $\mathbf{2 0 0 4}$ & $\mathbf{2 0 0 5}$ & $\mathbf{2 0 0 6}$ & $\mathbf{2 0 0 7}$ & $\mathbf{2 0 0 8}$ & $\mathbf{2 0 0 9}$ \\
\hline GDP & 44,569 & 47,471 & 50,554 & 53,596 & 56,311 & 57,766 & 58,133 \\
\hline
\end{tabular}

Source: Bureau of Economic Analysis (BEA)

\section{Truck Crossings Forecast}

An autoregressive integrated with moving averages (ARIMA) model was the preferred method to forecast tuck crossing. This type of equations evaluate future values of the dependent variable using historic values of the same variable, values of an independent variable, and the stationary processes to normalize data. The evaluated equation can be expressed as:

$$
\text { Trucks }_{t}=\beta_{1} \gamma U S G D P+(1-\phi) \text { Trucks }_{t-1}+\varepsilon_{t}
$$


Being USGDP the only explanatory variable apart from the lagged effect of the crossing trucks, the above equation indicates that as USGDP affects Maquiladora production, these must adjust their shipments.

Total border crossing trucks volumes forecast including both northbound (NB) and southbound (SB) trips were evaluated purely from 2010 to 2043 (see Table 3 and Figure 2).

Table 3. Total Border Crossing Trucks Volumes Forecast (NB and SB)

\begin{tabular}{|cc|cc|cc|cc|}
\hline Year & Total Trucks & Year & Total Trucks & Year & Total Trucks & Year & Total Trucks \\
\hline 2010 & $1,072,225$ & $\mathbf{2 0 1 9}$ & $1,233,300$ & $\mathbf{2 0 2 8}$ & $1,279,949$ & $\mathbf{2 0 3 7}$ & $1,325,568$ \\
2011 & $1,086,486$ & $\mathbf{2 0 2 0}$ & $1,197,561$ & $\mathbf{2 0 2 9}$ & $1,271,210$ & $\mathbf{2 0 3 8}$ & $1,319,829$ \\
2012 & $1,093,747$ & $\mathbf{2 0 2 1}$ & $1,241,822$ & $\mathbf{2 0 3 0}$ & $1,294,471$ & $\mathbf{2 0 3 9}$ & $1,326,090$ \\
2013 & $1,119,008$ & $\mathbf{2 0 2 2}$ & $1,206,083$ & $\mathbf{2 0 3 1}$ & $1,280,732$ & $\mathbf{2 0 4 0}$ & $1,328,351$ \\
2014 & $1,143,269$ & $\mathbf{2 0 2 3}$ & $1,260,344$ & $\mathbf{2 0 3 2}$ & $1,304,993$ & $\mathbf{2 0 4 1}$ & $1,334,063$ \\
2015 & $1,168,269$ & $\mathbf{2 0 2 4}$ & $1,226,905$ & $\mathbf{2 0 3 3}$ & $1,292,524$ & $\mathbf{2 0 4 2}$ & $1,339,483$ \\
2016 & $1,178,572$ & $\mathbf{2 0 2 5}$ & $1,281,166$ & $\mathbf{2 0 3 4}$ & $1,312,785$ & $\mathbf{2 0 4 3}$ & $1,346,984$ \\
2017 & $1,182,833$ & $\mathbf{2 0 2 6}$ & $1,263,427$ & $\mathbf{2 0 3 5}$ & $1,301,046$ & & \\
2018 & $1,215,800$ & $\mathbf{2 0 2 7}$ & $1,272,688$ & $\mathbf{2 0 3 6}$ & $1,322,307$ & & \\
\hline
\end{tabular}

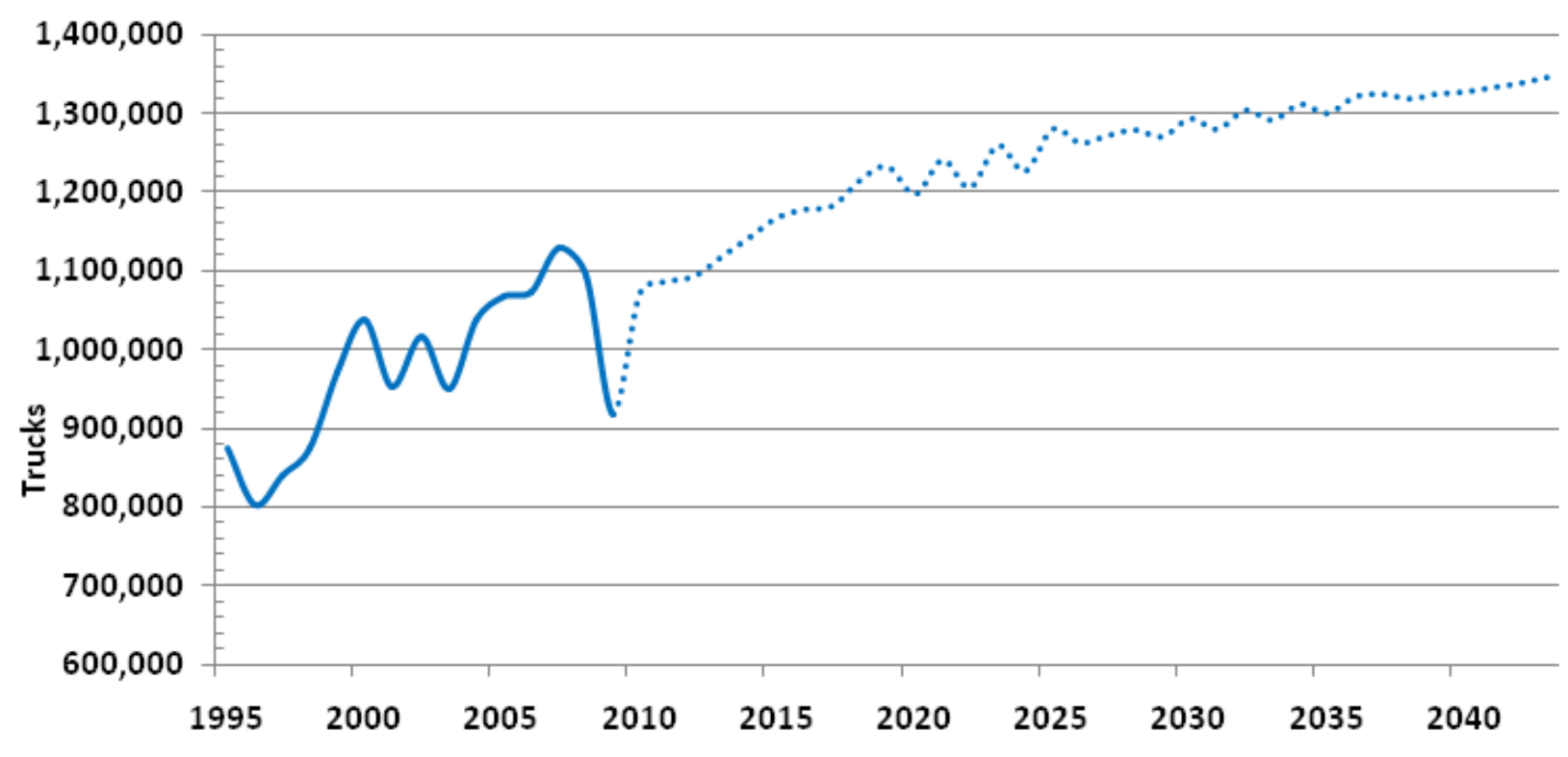

Figure 2. Total Border Crossing Trucks Volumes Historic and Forecast (NB and SB) 


\subsection{RECEPTIVITY OF REGIONAL SHIPPERS}

A market analysis was performed to explore current and future receptivity of regional shippers of the FSS services. To identify preferences from shippers in the region, first the market dimensions were identified through the application of surveys to maquiladoras in the region; then, market indicators were established to evaluate their willingness to use the FSS.

A total of 53 surveys were applied to obtain a statistically significant representation of all maquiladoras in the region. This represents more than $15 \%$ of total population of maquiladoras in El Paso - Ciudad Juarez market area. Translated into truck border crossings, these 53 maquiladoras account for 322 daily crossings, these guaranteed a confidence interval of $90 \%$ for all the evaluated years. A sample of the applied survey can be found on Appendix A. All parameters obtained from the survey were tested as potential elements of the probability model; however, only a few proven to significantly contribute to increased accuracy in the estimations (see Table 4).

Table 4. Market Variables.

\begin{tabular}{|c|c|}
\hline Market Indicator & Description \\
\hline Hired carriers & $\begin{array}{l}\text { Refers to the total number of carrier companies currently used by the } \\
\text { maquiladora. Its values include } 0 \text { for shipments operated within the } \\
\text { company; } 1 \text { when one external carrier company is hired; and } 2 \text { for two or } \\
\text { more hired carrier companies. }\end{array}$ \\
\hline Current cost & Considers the current price charged by carriers for a one-way trip. \\
\hline Reschedule & $\begin{array}{l}\text { Binary variable that indicates the ability of the company to spread their } \\
\text { achievements through the day. }\end{array}$ \\
\hline Maxprice & $\begin{array}{l}\text { Indicates the maximum price that companies are willing to pay for an } \\
\text { innovative border crossing system. }\end{array}$ \\
\hline Reduce time & $\begin{array}{l}\text { Qualitative variable that refers to the ability of the new system to cross } \\
\text { shipments at a reduced time. }\end{array}$ \\
\hline Simpinspect & $\begin{array}{l}\text { Qualitative variable that refers to the ability of the new system to simplify } \\
\text { border crossing inspections. }\end{array}$ \\
\hline
\end{tabular}

All except one of the variables were hypothesized to produce positively signed coefficients indicating that the probability of a shipment using the FSS increased as the value of the variables increased. As expected, the only variable hypothesized with a negative sign was Maxprice. Given the characteristic the FSS to be a normal service, it is expected that its demand decreases when its price increases. All these variables were used to build the probability model as described next.

\section{Market Capture Rate Probability Model}

A binomial logit model was identified as the most suitable option to forecasts probability of the potential FSS market capture rate. Resulting estimations indicated that 14 percent of the total border crossing trucks will be captured by the FSS in 2010 the base year. Tests conducted to this specification indicated a $99 \%$ of accuracy for the logit model. The logit follows the next specification:

$$
\operatorname{logit}\left(\pi_{i t}\right)=\beta_{i} \mathrm{x}_{i t}
$$


Some of the market indicators mentioned before were only valid for the base year; thus, before proceeding to forecast probabilities, it was necessary to forecast those market indicators that fluctuate over time. The variables forecasted were:

$$
\begin{aligned}
\text { maxprice } & =f \text { (inflation) } \\
\text { currentcost } & =f(\text { diesel, wages }) \\
\text { diesel } & =f \text { (inflation) } \\
\text { wages } & =f \text { (inflation) }
\end{aligned}
$$

As can be observed, the maximum price that companies are willing to pay for the FSS is contingent to inflationary tendencies. Whereas the price they are currently paying is contingent to current diesel prices and wages; also highly related to inflationary tendencies.

Inflation projections for U.S. and Mexico estimated based on data from the U.S. Department of Energy and the International Monetary Fund. Once having projections for inflation, an ARIMA model was used again to forecast Currentcost and Maxprice. Subsequently, the logit mentioned before was evaluated for every year from 2010 to 2043.

\section{Probability Scenario Development}

Based on the mentioned assumptions and given that the price that companies are willing to pay, either for the FSS or the traditional mode, is contingent to inflationary tendencies, three inflationary scenarios were created to account for uncertainty. These scenarios present variations in the probability of market capture rate as a result of applying the logit model individually for each of the market indicators assumed for every year. Inflation was the main component of the ARIMA developed to acknowledge for fluctuating variables. This culminated on annual sets of low, high, and most likely probabilities corresponding to each of the three different inflationary scenarios (see Table 5). 
Table 5. FSS Market Capture Rates Scenarios

\begin{tabular}{|c|c|c|c|}
\hline Year & Most Likely PD & High PD & Low PD \\
\hline 2010 & $14.05 \%$ & $14.05 \%$ & $14.05 \%$ \\
\hline 2011 & $14.18 \%$ & $14.23 \%$ & $14.16 \%$ \\
\hline 2012 & $14.83 \%$ & $14.87 \%$ & $14.81 \%$ \\
\hline 2013 & $19.14 \%$ & $19.22 \%$ & $19.11 \%$ \\
\hline 2014 & $19.12 \%$ & $19.88 \%$ & $18.25 \%$ \\
\hline 2015 & $18.40 \%$ & $19.27 \%$ & $17.36 \%$ \\
\hline 2016 & $19.90 \%$ & $21.93 \%$ & $19.65 \%$ \\
\hline 2017 & $21.68 \%$ & $23.41 \%$ & $20.74 \%$ \\
\hline 2018 & $23.67 \%$ & $25.00 \%$ & $22.44 \%$ \\
\hline 2019 & $26.54 \%$ & $29.07 \%$ & $25.91 \%$ \\
\hline 2020 & $28.07 \%$ & $30.72 \%$ & $27.46 \%$ \\
\hline 2021 & $30.87 \%$ & $33.59 \%$ & $30.15 \%$ \\
\hline 2022 & $32.51 \%$ & $34.56 \%$ & $31.43 \%$ \\
\hline 2023 & $35.23 \%$ & $37.95 \%$ & $34.39 \%$ \\
\hline 2024 & $37.13 \%$ & $39.90 \%$ & $36.17 \%$ \\
\hline 2025 & $38.98 \%$ & $40.85 \%$ & $37.49 \%$ \\
\hline 2026 & $39.34 \%$ & $41.64 \%$ & $38.15 \%$ \\
\hline 2027 & $40.13 \%$ & $42.26 \%$ & $38.75 \%$ \\
\hline 2028 & $38.58 \%$ & $40.35 \%$ & $37.03 \%$ \\
\hline 2029 & $36.67 \%$ & $38.37 \%$ & $34.79 \%$ \\
\hline 2030 & $37.07 \%$ & $39.32 \%$ & $35.13 \%$ \\
\hline 2031 & $37.96 \%$ & $39.72 \%$ & $36.24 \%$ \\
\hline 2032 & $38.91 \%$ & $40.82 \%$ & $37.28 \%$ \\
\hline 2033 & $40.12 \%$ & $42.29 \%$ & $38.10 \%$ \\
\hline 2034 & $41.22 \%$ & $43.36 \%$ & $39.33 \%$ \\
\hline 2035 & $42.49 \%$ & $44.56 \%$ & $40.70 \%$ \\
\hline 2036 & $43.55 \%$ & $45.91 \%$ & $41.46 \%$ \\
\hline 2037 & $44.55 \%$ & $47.39 \%$ & $42.20 \%$ \\
\hline 2038 & $45.33 \%$ & $47.77 \%$ & $43.30 \%$ \\
\hline 2039 & $46.18 \%$ & $48.92 \%$ & $43.82 \%$ \\
\hline 2040 & $46.86 \%$ & $49.68 \%$ & $44.60 \%$ \\
\hline 2041 & $47.69 \%$ & $50.68 \%$ & $45.38 \%$ \\
\hline 2042 & $48.01 \%$ & $51.11 \%$ & $45.58 \%$ \\
\hline 2043 & $48.63 \%$ & $51.77 \%$ & $46.16 \%$ \\
\hline
\end{tabular}




\subsection{POTENTIAL FSS TRAFFIC}

After forecasting the truck border crossing volumes and the probability of demand, the next step was to apply the percentages of market capture rate to the projected total border crossings. The obtained are the total number of trips per year operated by the FSS for the three scenarios (see Table 6).

Table 6. Potential FSS Cross-Border Container Moves.

\begin{tabular}{|c|c|c|c|c|}
\multirow{2}{*}{ Year } & Cross-Border & \multicolumn{3}{|c|}{ FSS Market Capture } \\
\cline { 3 - 5 } & Truck Traffic & Most Likely PD & High PD & Low PD \\
\hline 2010 & $1,072,225$ & 150,648 & 150,648 & 150,648 \\
\hline 2011 & $1,086,486$ & 154,064 & 154,637 & 153,885 \\
\hline 2012 & $1,093,747$ & 162,203 & 162,677 & 162,010 \\
\hline 2013 & $1,119,008$ & 214,178 & 215,113 & 213,846 \\
\hline 2014 & $1,143,269$ & 218,564 & 227,226 & 208,634 \\
\hline 2015 & $1,168,269$ & 214,924 & 225,118 & 202,815 \\
\hline 2016 & $1,178,572$ & 234,552 & 258,417 & 231,598 \\
\hline 2017 & $1,182,833$ & 256,439 & 276,854 & 245,300 \\
\hline 2018 & $1,215,800$ & 287,789 & 303,954 & 272,857 \\
\hline 2019 & $1,233,300$ & 327,372 & 358,482 & 319,587 \\
\hline 2020 & $1,197,561$ & 336,206 & 367,848 & 328,816 \\
\hline 2021 & $1,241,822$ & 383,369 & 417,184 & 374,397 \\
\hline 2022 & $1,206,083$ & 392,136 & 416,809 & 379,040 \\
\hline 2023 & $1,260,344$ & 444,061 & 478,275 & 433,475 \\
\hline 2024 & $1,226,905$ & 455,522 & 489,483 & 443,817 \\
\hline 2025 & $1,281,166$ & 499,344 & 523,347 & 480,274 \\
\hline 2026 & $1,263,427$ & 497,070 & 526,079 & 482,000 \\
\hline 2027 & $1,272,688$ & 510,792 & 537,847 & 493,141 \\
\hline 2028 & $1,279,949$ & 493,838 & 516,432 & 473,915 \\
\hline 2029 & $1,271,210$ & 466,205 & 487,744 & 442,252 \\
\hline 2030 & $1,294,471$ & 479,856 & 508,986 & 454,810 \\
\hline 2031 & $1,280,732$ & 486,183 & 508,715 & 464,115 \\
\hline 2032 & $1,304,993$ & 507,834 & 532,640 & 486,438 \\
\hline 2033 & $1,292,524$ & 518,584 & 546,611 & 492,516 \\
\hline 2034 & $1,312,785$ & 541,170 & 569,171 & 516,382 \\
\hline 2035 & $1,301,046$ & 552,760 & 579,789 & 529,548 \\
\hline 2036 & $1,322,307$ & 575,835 & 607,032 & 548,233 \\
\hline 2037 & $1,325,568$ & 590,564 & 628,192 & 559,451 \\
\hline 2038 & $1,319,829$ & 598,300 & 630,482 & 571,445 \\
\hline 2039 & $1,326,090$ & 612,386 & 648,707 & 581,142 \\
\hline 2040 & $1,328,351$ & 622,516 & 659,973 & 592,507 \\
\hline 2041 & $1,334,063$ & 636,204 & 676,081 & 605,459 \\
\hline 2042 & $1,339,483$ & 643,020 & 684,557 & 610,547 \\
\hline 2043 & $1,346,984$ & 655,075 & 697,309 & 621,804 \\
\hline & & & & \\
\hline
\end{tabular}


All three scenarios were based on projected inflationary fluctuations; therefore, variations on the expected number of trips operated by the FSS are likely to reflect variations in the expected inflation. An example of these abrupt fluctuations is observed between 2027 and 2029 (see Figure 3).

Although all three scenarios oscillate in similar way, traffic demand is more sensitive to elevated prices. For all years, high inflation seems to produce larger changes from the mostlikely scenario than those changes resulting from low inflation. This could be due to the close relationship between inflation and the industrial production index, as well as the fact that inflation in wages and diesel prices seem to affect more traditional modes than the FSS. On the other hand, low price levels do not seem to have a significant impact on the FSS demand.

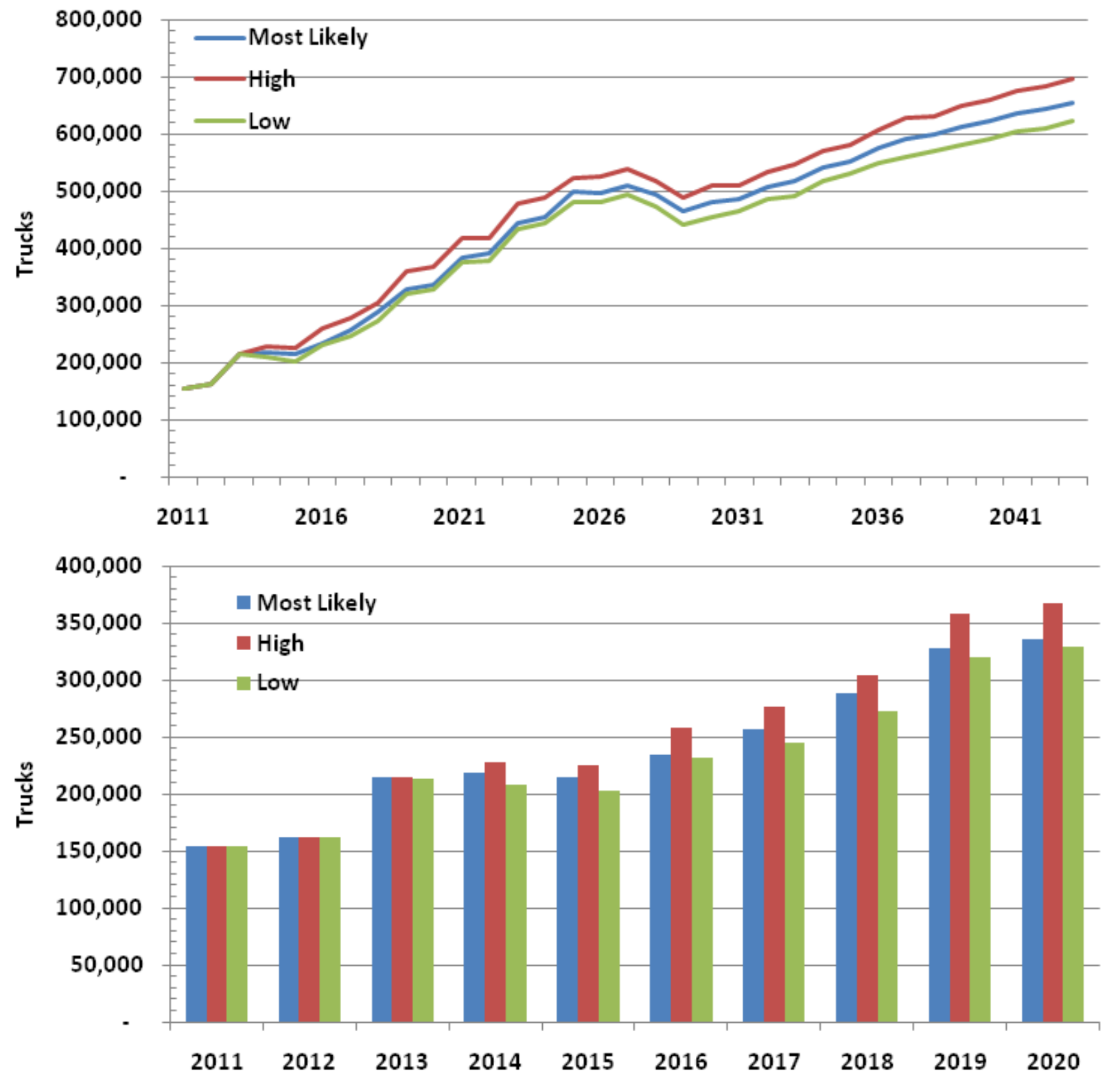

Figure 3. FSS Minimum, Maximum and Most Likely Market Capture 


\subsection{CHAPTER SUMMARY AND RECOMMENDATIONS}

This chapter has explained the four procedures used to forecast the potential FSS traffic: (i) border crossing truck volumes were forecasted using ARIMA; (ii) a logit estimation was used to calculate current probabilities of usage; (iii) a second ARIMA was required to forecast variables of the logit; and (iv) new runs of the logit specification using forecasted variables served as a way to estimate future probabilities.

For the truck crossing projections, only US GDP proved to be statistically significant, as the US GDP is highly correlated with the Maquiladora production; hence, Maquiladora shipments. With some minor fluctuations, the total number of border crossing trucks is expected to increase in the next thirty years.

The market analysis identified that six preferences have a more significant weight on the decision-making process from the shippers. Surveys revealed that shippers greatly value the qualitative advantages of the FSS, such as providing a faster, reliable crossing and simplifying inspections. They also base their decision depending on how many carriers they currently have and whether they can spread their shipments through the day. Finally, both prices of the FSS and that of its competitors contribute in the decision making.

Once having future volumes of truck and future usage probabilities, the combination of these elements indicated the actual number of trucks willing to use the FSS now and in the upcoming years. Although high inflations seem to have larger impacts on the probabilities, trends for the three scenarios fluctuate similarly.

Demand for the FSS will likely increase for the next 16 years. However, the model considers a small drop in demand from 2027 to 2029 . One possible cause is a potential decline in inflation, which makes the competitor's price attractive again. After 2029, it starts to increase again serving around 650,000 trips per year in 2043.

One limitation of this model is that it only considers that diesel prices are impacted by inflation; however, a decrease in the quantity supplied of diesel, or oil reserves, might also have a significant impact on the competitor's price-making the FSS the most cost-efficient alternative for maquiladoras. 


\section{CHAPTER 3:}

\section{CHANGES TO LOGISTICS PRACTICES}

\subsection{OVERVIEW}

This Chapter examines the current logistics practices to assess the changes required for shipments to emanate a centralized, government-operated inspections terminal. The evaluation includes an assessment of the vehicle miles traveled (VMT) savings, based on the potential routes, which could accrue with a well place inland terminal.

This chapter includes the following sections:

3.2 Changes to Existing Logistics Practices. This section discusses the existing logistics practices utilized in the El Paso region to facilitate cross-border movements.

3.3 Changes in Truck Vehicle Miles Traveled with FSS Implementation. This section calculates the changes in truck vehicle miles traveled provided implementation of the FSS system.

3.4 Chapter Summary and Recommendations. This section summarizes the findings and conclusions of each section.

\subsection{CHANGES TO EXISTING LOGISTICS PRACTICES}

The objective of this section is to describe the current logistics practices, and the changes that inland FSS terminals would require in the El Paso-Ciudad Juarez region. Current logistics practices in this area are driven by the Maquiladora industry. Maquiladoras are typically manufacturing operations that import components from the US, on a temporary basis, for assembly and subsequent export back to the US for final consumption. Since importation of goods is temporary, maquiladoras are often able to assemble goods and return them back to the US without paying a duty or tariff. Due to these tax incentives and the ability to garner cheaper labor rates, some US companies have strategically located themselves along the border. This strategic repositioning has imparted significant demand at border ports due to the required dray movements into and out of maquiladoras in Mexico.

According to the El Paso Regional Economic Development Corporation (REDCo), twenty five percent of all trade that crosses between the US and Mexico passes through the El PasoCiudad Juarez border, which is largely due to the strong maquila industry in that area. A 2009 TxDOT report, 0-5684-1, examined the dray activity at the Texas-Mexico border and identified twelve industrial areas in El Paso, as shown in Figure 4. In this region, the twelve industrial areas are primarily tied to analogous Maquiladora facilities across the border, and goods flow across the border through either the Bridge of the Americas (BOTA) or Zaragoza port of entry. 


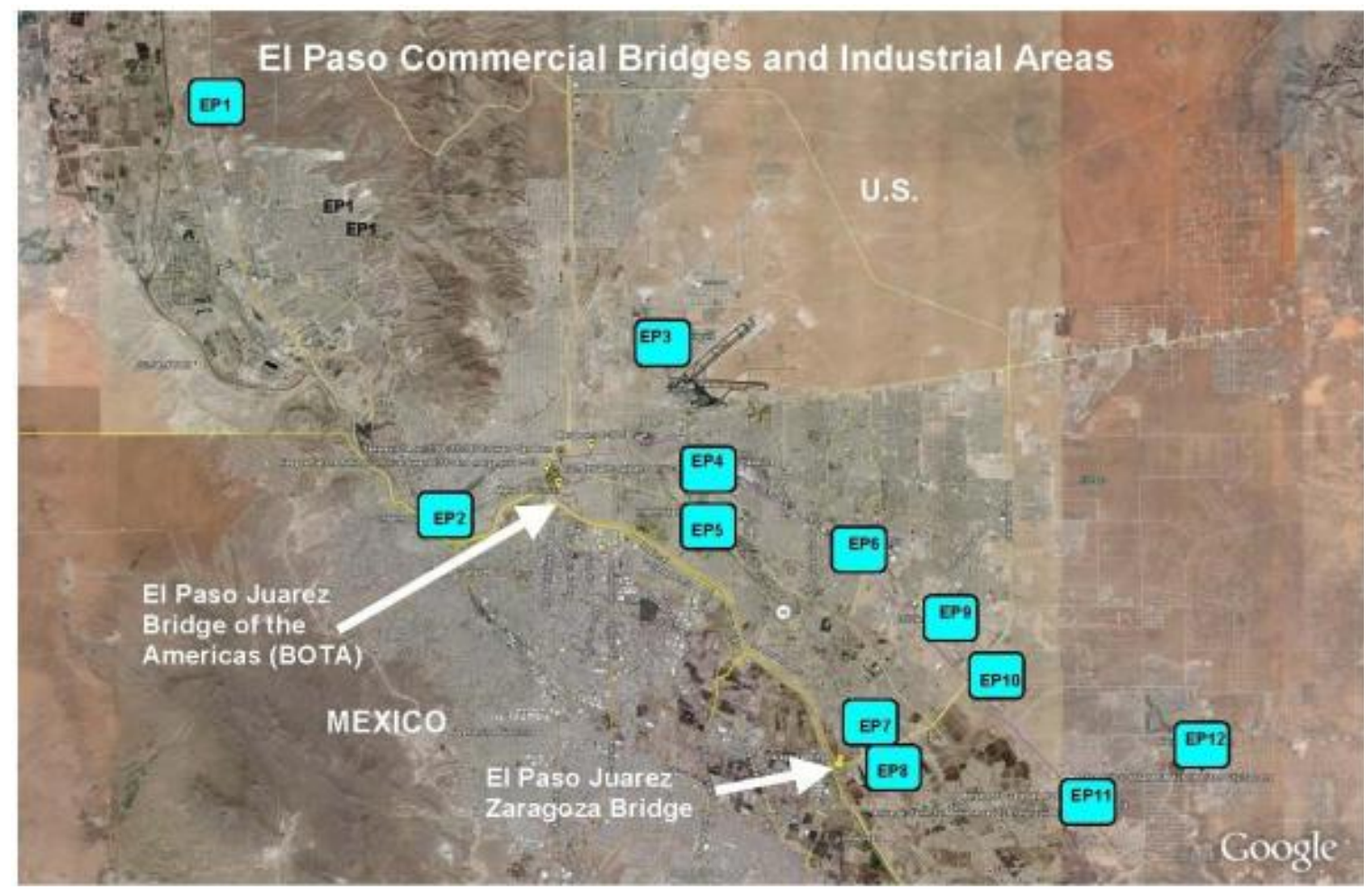

Source: Harrison, 2009 (1)

Figure 4. Map of El Paso Commercial Bridges and Industrial Areas

The implementation of the FSS in this region would require the placement of inland terminals, on both sides of the border, in a strategic location that minimizes the distance to both industrial areas and Maquiladora clusters. The two inland terminals would be linked together by an elevated, dedicated guideway that runs nonstop through the border. This configuration will eliminate the need for dray movements that currently congest our nation's ports of entry. A simplified schematic of the before and after process is provided in Figure 5. 


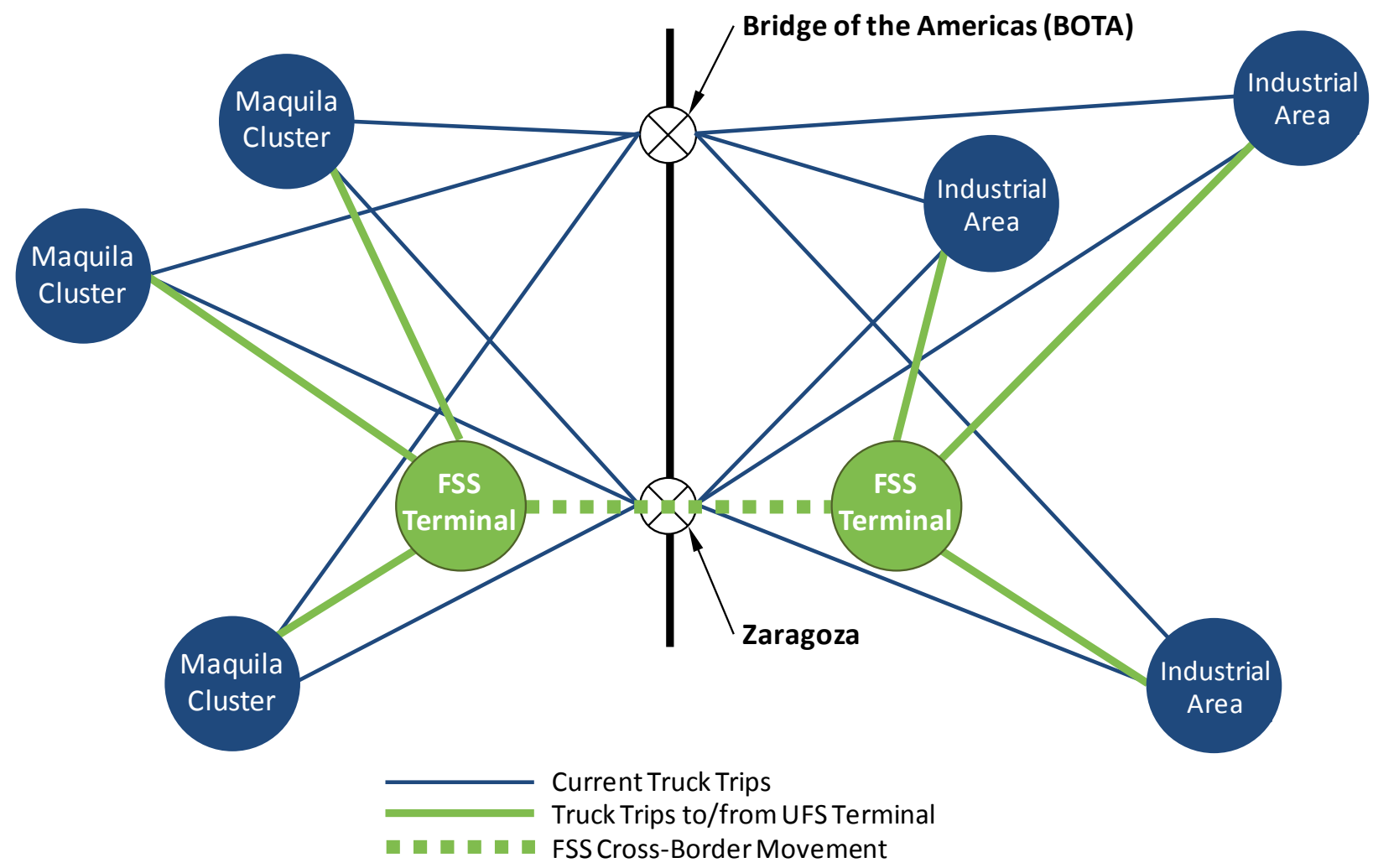

Figure 5. Comparison of Existing and FSS Truck Flows in the EI Paso Area

\subsection{CHANGE IN TRUCK VEHICLE MILES TRAVELED WITH FSS IMPLEMENTATION}

The objectives of this section is to calculate the change in vehicle miles traveled (VMT) by implementing FSS terminals in El Paso and Ciudad Juarez. Currently, dray trucks travel between points in El Paso and Ciudad Juarez through one of the two major commercial truck international bridges. Implementation of the FSS system integrates the transfer of those shipments in the FSS inland terminals where the cross-border movement is performed by the FSS. A thorough discussion of the most likely terminal locations is included in Chapter 4. However, for this analysis, it is assumed the system will consist of a 10-mile cross-border system with terminals located five miles from the border on each side at the Zaragoza Bridge.

Therefore the approach consists of calculating the change in vehicle miles traveled based on replacing a calculated level of truck trips between major industrial areas and the Bridge of the Americas (BOTA) and Zaragoza with truck trips to and from a FSS terminal (see Figure 5). The calculated change in VMT values are used later in the emission calculation with the implementation of the FSS. 


\section{Identification of Industrial Areas}

The authors of TxDOT report, 0-5684-1 distributed the number of truck trips to each industrial area based on the relative complex size. The truck trips were then allocated to either the Bridge of the Americas (BOTA) located in central El Paso or the Zaragoza Bridge located to the south of El Paso based on the total number of truck movements across each border crossing. Also calculated was the estimated distance between each of the 12 industrial areas and the two bridges. Table 7 and Table 8 show the industrial areas identified in the El Paso area along with the size, number of trips estimated, distances to the bridges, and the calculated VMT.

Table 7. EI Paso BOTA Bridge, Industrial Areas, Trip Distances, and VMT

\begin{tabular}{|c|c|c|c|c|c|c|}
\hline $\begin{array}{l}\text { Industrial } \\
\text { Area }\end{array}$ & Location & Acres & $\begin{array}{l}\% \text { of Trips=Total } \\
\text { Area/Industrial } \\
\text { Area }\end{array}$ & $\begin{array}{l}\text { BOTA } \\
\text { Number } \\
\text { of Trips }\end{array}$ & $\begin{array}{l}\text { Distance BOTA } \\
\text { to Industrial } \\
\text { Area }\end{array}$ & $\begin{array}{l}\text { Total } \\
\text { VMT Over } \\
\text { BOTA }\end{array}$ \\
\hline EP1 & IH 10 PaseoDelNorte & 360 & 0.13 & 113,374 & 19 & $2,155,756$ \\
\hline $\mathrm{EP} 2$ & Intermodal Canal Rd & 46 & 0.02 & 14,487 & 3 & 45,910 \\
\hline EP3 & Airport-Leigh Fisher & 554 & 0.20 & 174,471 & 5 & 932,361 \\
\hline EP4 & IH 10 Hawkins & 63 & 0.02 & 19,841 & 6 & 109,725 \\
\hline EP5 & Intermodal Stiles Dr & 87 & 0.03 & 27,399 & 5 & 127,690 \\
\hline EP6 & IH $10-N$ Lee Trevino & 125 & 0.04 & 39,366 & 10 & 379,156 \\
\hline EP7 & N LP 375-Pan American & 148 & 0.05 & 46,610 & 12 & 538,704 \\
\hline EP8 & S LP 375-Pan American & 216 & 0.08 & 68,025 & 11 & 773,536 \\
\hline EP9 & IH 10-N Zaragoza & 612 & 0.22 & 192,737 & 12 & $2,275,521$ \\
\hline EP10 & IH 10-LP 375 & 316 & 0.11 & 99,518 & 14 & $1,385,195$ \\
\hline EP11 & IH $10-$ Horizon & 89 & 0.03 & 28,029 & 17 & 473,734 \\
\hline \multirow[t]{2}{*}{ EP12 } & Horizon Rd-Darrington Rd & 218 & 0.08 & 68,655 & 21 & $1,441,946$ \\
\hline & & 2,834 & & 892,509 & & $10,639,233$ \\
\hline \multicolumn{2}{|c|}{ Total BOTA Trips 892,509} & & & & & \\
\hline
\end{tabular}

Source: Harrison, 2009 (1) 
Table 8. El Paso Zaragoza Bridge, Industrial Areas, Trip Distances, and VMT

\begin{tabular}{|c|c|c|c|c|c|c|}
\hline $\begin{array}{l}\text { Industrial } \\
\text { Area }\end{array}$ & Location & Acres & $\begin{array}{l}\% \text { of } \\
\text { Trips=Total } \\
\text { Area/Industrial } \\
\text { Area }\end{array}$ & $\begin{array}{l}\text { Zaragoza } \\
\text { Number } \\
\text { of Trips } \\
\end{array}$ & $\begin{array}{l}\text { Miles } \\
\text { Distance } \\
\text { Zaragoza } \\
\text { to } \\
\text { Industrial } \\
\text { Areas } \\
\end{array}$ & $\begin{array}{l}\text { Total } \\
\text { VMT Over } \\
\text { Zaragoza }\end{array}$ \\
\hline EP1 & IH 10 PaseoDelNorte & 360 & 0.13 & 85,392 & 30 & $2,546,970$ \\
\hline $\mathrm{EP} 2$ & Intermodal Canal Rd & 46 & 0.02 & 10,911 & 13 & 143,061 \\
\hline EP3 & Airport-Leigh Fisher & 554 & 0.20 & 131,410 & 15 & $1,992,415$ \\
\hline EP4 & IH 10 Hawkins & 63 & 0.02 & 14,944 & 9 & 130,002 \\
\hline EP5 & Intermodal Stiles Dr & 87 & 0.03 & 20,637 & 8 & 156,444 \\
\hline EP6 & IH 10-N Lee Trevino & 125 & 0.04 & 29,650 & 6 & 171,346 \\
\hline EP7 & N LP 375-Pan American & 148 & 0.05 & 35,106 & 1 & 43,629 \\
\hline EP8 & S LP 375-Pan American & 216 & 0.08 & 51,235 & 1 & 66,858 \\
\hline EP9 & IH 10-N Zaragoza & 612 & 0.22 & 145,167 & 5 & 685,560 \\
\hline EP10 & IH 10-LP 375 & 316 & 0.11 & 74,956 & 5 & 363,297 \\
\hline EP11 & IH 10-Horizon & 89 & 0.03 & 21,111 & 8 & 167,911 \\
\hline \multirow[t]{2}{*}{ EP12 } & $\begin{array}{l}\text { Horizon Rd-Darrington } \\
\text { Rd }\end{array}$ & 218 & 0.08 & 51,710 & 12 & 623,359 \\
\hline & & 2,834 & & 672,229 & & $7,090,851$ \\
\hline Total Zarag & za Trips 672,229 & & & & & \\
\hline
\end{tabular}

Source: Harrison, 2009 (1)

\section{Cross-Border Truck Trips}

This analysis utilized the findings from the TxDOT 0-5684-1 report to distribute the truck trips between the industrial areas and the border crossings. The total number of truck trips in the El Paso area reported by the report equals 1,564,739 trips in 2007. The detailed economic analysis performed for this feasibility project includes detailed analysis of annual cross-border truck trips in El Paso and also the expected trips captured by implementing the FSS. To accomplish the objectives of this VMT calculation, TTI developed a ratio of the FSS trips to the TxDOT 0-56841 report trips in order to distribute the economic analysis calculated annual trips projected out to 2037 between the industrial areas and the border crossings and FSS terminal. Table 9 shows the calculated annual cross-border trips and the expected annual FSS capture rate. 
Table 9. Annual El Paso Cross-Border Truck Trips and Expected Annual FSS Capture Rate

\begin{tabular}{|lc|c|c|}
\hline \multicolumn{2}{|c|}{ Year } & Total Annual El Paso Trips & Annual FSS Capture Rate \\
\hline $\mathbf{1}$ & $\mathbf{2 0 1 4}$ & $1,143,269$ & $19.12 \%$ \\
\hline $\mathbf{2}$ & $\mathbf{2 0 1 5}$ & $1,168,269$ & $18.40 \%$ \\
\hline $\mathbf{3}$ & $\mathbf{2 0 1 6}$ & $1,178,572$ & $19.90 \%$ \\
\hline $\mathbf{4}$ & $\mathbf{2 0 1 7}$ & $1,182,833$ & $21.68 \%$ \\
\hline $\mathbf{5}$ & $\mathbf{2 0 1 8}$ & $1,215,800$ & $23.67 \%$ \\
\hline $\mathbf{6}$ & $\mathbf{2 0 1 9}$ & $1,233,300$ & $26.54 \%$ \\
\hline $\mathbf{7}$ & $\mathbf{2 0 2 0}$ & $1,197,561$ & $28.07 \%$ \\
\hline $\mathbf{8}$ & $\mathbf{2 0 2 1}$ & $1,241,822$ & $30.87 \%$ \\
\hline $\mathbf{9}$ & $\mathbf{2 0 2 2}$ & $1,206,083$ & $32.51 \%$ \\
\hline $\mathbf{1 0}$ & $\mathbf{2 0 2 3}$ & $1,260,344$ & $35.23 \%$ \\
\hline $\mathbf{1 1}$ & $\mathbf{2 0 2 4}$ & $1,226,905$ & $37.13 \%$ \\
\hline $\mathbf{1 2}$ & $\mathbf{2 0 2 5}$ & $1,281,166$ & $38.98 \%$ \\
\hline $\mathbf{1 3}$ & $\mathbf{2 0 2 6}$ & $1,263,427$ & $39.34 \%$ \\
\hline $\mathbf{1 4}$ & $\mathbf{2 0 2 7}$ & $1,272,688$ & $40.13 \%$ \\
\hline $\mathbf{1 5}$ & $\mathbf{2 0 2 8}$ & $1,279,949$ & $38.58 \%$ \\
\hline $\mathbf{1 6}$ & $\mathbf{2 0 2 9}$ & $1,271,210$ & $36.67 \%$ \\
\hline $\mathbf{1 7}$ & $\mathbf{2 0 3 0}$ & $1,294,471$ & $37.07 \%$ \\
\hline $\mathbf{1 8}$ & $\mathbf{2 0 3 1}$ & $1,280,732$ & $37.96 \%$ \\
\hline $\mathbf{1 9}$ & $\mathbf{2 0 3 2}$ & $1,304,993$ & $38.91 \%$ \\
\hline $\mathbf{2 0}$ & $\mathbf{2 0 3 3}$ & $1,292,524$ & $40.12 \%$ \\
\hline $\mathbf{2 1}$ & $\mathbf{2 0 3 4}$ & $1,312,785$ & $41.22 \%$ \\
\hline $\mathbf{2 2}$ & $\mathbf{2 0 3 5}$ & $1,301,046$ & $42.49 \%$ \\
\hline $\mathbf{2 3}$ & $\mathbf{2 0 3 6}$ & $1,322,307$ & $44.55 \%$ \\
\hline $\mathbf{2 4}$ & $\mathbf{2 0 3 7}$ & $1,325,568$ & \\
\hline & & & \\
\hline
\end{tabular}

\section{Vehicle Miles Traveled Calculation}

As stated previously, the VMT analysis assumes a single FSS terminal on each side of the border that is located five miles from the existing Zaragoza border crossing. The distances between the 12 industrial areas and the two border crossings are presented in TxDOT Report 0-5684-1. However, for this analysis the research team more precisely calculated the distances by dividing the VMT values by the number of trips. The distances between the industrial areas and the FSS terminal are assumed to be the distance between the industrial areas and the Zaragoza Bridge minus five miles. Table 10 contains the distances utilized to calculate the VMT. 
Table 10. Distances between the El Paso Industrial Areas and the Border Crossings and FSS Terminal

\begin{tabular}{|c|c|c|c|}
\hline Industrial Area & $\begin{array}{c}\text { Distance BOTA to } \\
\text { Industrial Area }\end{array}$ & $\begin{array}{c}\text { Distance Zaragoza to } \\
\text { Industrial Area }\end{array}$ & Distance to FSS Terminal \\
\hline EP1 & 19.0 & 29.8 & 24.8 \\
\hline EP2 & 3.2 & 13.1 & 8.1 \\
\hline EP3 & 5.3 & 15.2 & 10.2 \\
\hline EP4 & 5.5 & 8.7 & 3.7 \\
\hline EP5 & 4.7 & 7.6 & 2.6 \\
\hline EP6 & 9.6 & 5.8 & 0.8 \\
\hline EP7 & 11.6 & 1.2 & 3.8 \\
\hline EP8 & 11.4 & 1.3 & 3.7 \\
\hline EP9 & 11.8 & 4.7 & 0.3 \\
\hline EP10 & 13.9 & 4.8 & 0.2 \\
\hline EP11 & 16.9 & 8.0 & 3.0 \\
\hline EP12 & 21.0 & 12.1 & 7.1 \\
\hline Total & 133.9 & 112.3 & 68.1 \\
\hline
\end{tabular}

The vehicle miles traveled is calculated annually utilizing the calculated distances and the truck trips calculated in the detailed economic analysis described later in this report distributed to the twelve El Paso industrial areas. The VMT for the current conditions is then compared to the VMT given implementation of the FSS cross-border system. Table 11 includes the VMT calculations, including the change in VMT with the FSS in operation. It shows that in the first year of operation, 2014, there would be an 8.56\% reduction in VMT but would grow to $22.51 \%$ in 2037 as more of the cross-border trips are captured by the FSS. 
Table 11. Change in EI Paso VMT with FSS Implementation

\begin{tabular}{|c|c|c|c|c|c|c|c|c|c|c|}
\hline \multirow{2}{*}{\multicolumn{2}{|c|}{ Year }} & \multicolumn{3}{|c|}{ Total VMT Over BOTA } & \multicolumn{3}{|c|}{ Total VMT Over Zaragoza } & \multicolumn{3}{|c|}{ Total VMT } \\
\hline & & Current & With FSS & Diff. & Current & With FSS & Diff. & Current & With FSS & Diff. \\
\hline 1 & 2014 & $7,773,495$ & $7,117,422$ & $-9.22 \%$ & $5,180,890$ & $4,815,598$ & $-7.59 \%$ & $12,954,385$ & $11,933,020$ & $-8.56 \%$ \\
\hline 2 & 2015 & $7,943,479$ & $7,298,332$ & $-8.84 \%$ & $5,294,181$ & $4,934,973$ & $-7.28 \%$ & $13,237,660$ & $12,233,304$ & $-8.21 \%$ \\
\hline 3 & 2016 & $8,013,533$ & $7,309,468$ & $-9.63 \%$ & $5,340,871$ & $4,948,858$ & $-7.92 \%$ & $13,354,404$ & $12,258,326$ & $-8.94 \%$ \\
\hline 4 & 2017 & $8,042,505$ & $7,272,741$ & $-10.58 \%$ & $5,360,180$ & $4,931,587$ & $-8.69 \%$ & $13,402,685$ & $12,204,328$ & $-9.82 \%$ \\
\hline 5 & 2018 & $8,266,659$ & $7,402,791$ & $-11.67 \%$ & $5,509,575$ & $5,028,586$ & $-9.57 \%$ & $13,776,234$ & $12,431,377$ & $-10.82 \%$ \\
\hline 6 & 2019 & $8,385,648$ & $7,402,962$ & $-13.27 \%$ & $5,588,879$ & $5,041,734$ & $-10.85 \%$ & $13,974,527$ & $12,444,696$ & $-12.29 \%$ \\
\hline 7 & 2020 & $8,142,646$ & $7,133,441$ & $-14.15 \%$ & $5,426,922$ & $4,865,012$ & $-11.55 \%$ & $13,569,568$ & $11,998,453$ & $-13.09 \%$ \\
\hline 8 & 2021 & $8,443,592$ & $7,292,818$ & $-15.78 \%$ & $5,627,497$ & $4,986,763$ & $-12.85 \%$ & $14,071,090$ & $12,279,580$ & $-14.59 \%$ \\
\hline 9 & 2022 & $8,200,590$ & $7,023,498$ & $-16.76 \%$ & $5,465,541$ & $4,810,153$ & $-13.63 \%$ & $13,666,131$ & $11,833,652$ & $-15.49 \%$ \\
\hline 10 & 2023 & $8,569,530$ & $7,236,574$ & $-18.42 \%$ & $5,711,433$ & $4,969,262$ & $-14.94 \%$ & $14,280,962$ & $12,205,835$ & $-17.00 \%$ \\
\hline 11 & 2024 & $8,342,166$ & $6,974,808$ & $-19.60 \%$ & $5,559,899$ & $4,798,574$ & $-15.87 \%$ & $13,902,065$ & $11,773,382$ & $-18.08 \%$ \\
\hline 12 & 2025 & $8,711,106$ & $7,212,206$ & $-20.78 \%$ & $5,805,791$ & $4,971,224$ & $-16.79 \%$ & $14,516,897$ & $12,183,430$ & $-19.15 \%$ \\
\hline 13 & 2026 & $8,590,492$ & $7,098,417$ & $-21.02 \%$ & $5,725,404$ & $4,894,638$ & $-16.97 \%$ & $14,315,896$ & $11,993,055$ & $-19.37 \%$ \\
\hline 14 & 2027 & $8,653,461$ & $7,120,196$ & $-21.53 \%$ & $5,767,371$ & $4,913,671$ & $-17.37 \%$ & $14,420,832$ & $12,033,868$ & $-19.84 \%$ \\
\hline 15 & 2028 & $8,702,831$ & $7,220,456$ & $-20.53 \%$ & $5,800,276$ & $4,974,911$ & $-16.59 \%$ & $14,503,107$ & $12,195,367$ & $-18.92 \%$ \\
\hline 16 & 2029 & $8,643,412$ & $7,243,984$ & $-19.32 \%$ & $5,760,673$ & $4,981,492$ & $-15.64 \%$ & $14,404,085$ & $12,225,476$ & $-17.82 \%$ \\
\hline 17 & 2030 & $8,801,572$ & $7,361,169$ & $-19.57 \%$ & $5,866,084$ & $5,064,089$ & $-15.84 \%$ & $14,667,656$ & $12,425,257$ & $-18.05 \%$ \\
\hline 18 & 2031 & $8,708,155$ & $7,248,759$ & $-20.13 \%$ & $5,803,824$ & $4,991,253$ & $-16.28 \%$ & $14,511,979$ & $12,240,012$ & $-18.56 \%$ \\
\hline 19 & 2032 & $8,873,114$ & $7,348,728$ & $-20.74 \%$ & $5,913,766$ & $5,065,010$ & $-16.76 \%$ & $14,786,880$ & $12,413,738$ & $-19.12 \%$ \\
\hline 20 & 2033 & $8,788,333$ & $7,231,678$ & $-21.53 \%$ & $5,857,261$ & $4,990,538$ & $-17.37 \%$ & $14,645,594$ & $12,222,216$ & $-19.83 \%$ \\
\hline 21 & 2034 & $8,926,095$ & $7,301,642$ & $-22.25 \%$ & $5,949,077$ & $5,044,605$ & $-17.93 \%$ & $14,875,172$ & $12,346,246$ & $-20.48 \%$ \\
\hline 22 & 2035 & $8,846,277$ & $7,187,034$ & $-23.09 \%$ & $5,895,880$ & $4,972,037$ & $-18.58 \%$ & $14,742,157$ & $12,159,071$ & $-21.24 \%$ \\
\hline 23 & 2036 & $8,990,838$ & $7,262,330$ & $-23.80 \%$ & $5,992,227$ & $5,029,818$ & $-19.13 \%$ & $14,983,065$ & $12,292,148$ & $-21.89 \%$ \\
\hline 24 & 2037 & $9,013,011$ & $7,240,291$ & $-24.48 \%$ & $6,007,005$ & $5,019,980$ & $-19.66 \%$ & $15,020,016$ & $12,260,271$ & $-22.51 \%$ \\
\hline
\end{tabular}




\subsection{CHAPTER SUMMARY}

The findings indicate a 22 percent reduction in VMT traveled for cross-border truck trips in El Paso in 2037 with the implementation of the FSS system for cross-border movements. The relatively short distances between the industrial areas and the border crossings and FSS terminal made it unlikely to contribute major reductions in VMT. However, the significant levels of trucks utilizing the FSS system over time create a significant VMT reduction level. The VMT calculations are utilized later as part of the overall process to estimate the change in truck emissions with the implementation of the FSS. 



\section{CHAPTER 4:}

\section{TERMINALS AND BORDER CROSSING TARGET LOCATIONS}

\subsection{OVERVIEW}

The objective of this chapter is to identify target locations for terminals, inspect-in-motion facilities, and a viable port of entry (POE) to explore alternatives for the FSS system configuration; furthermore, to assess the feasibility of binational operations in the El Paso Ciudad Juarez region.

Since the warehousing, distribution, and maquiladora operations comprise the FSS potential market, by integration of the FSS concept to their supply chain operations, this chapter analyzes the area with the highest concentration of such operations to identify the location of these industries and potential FSS customers. The basis of this research is a combination of geospatial analysis, online information, and interviews with government officials and maquiladoras on both cities.

This chapter includes the following sections:

4.2 Location of Potential Customers. This analysis explores the location of potential customers for the FSS in the El Paso - Ciudad Juarez binational region; at the same time, it assesses truck routes providing connectivity to the FSS potential customers.

4.3 Border - Crossing Analysis. After assessing all POEs in the El Paso - Ciudad Juarez region, this section presents the Ysleta-Zaragoza POE as the most viable alternative for a FSS border-crossing. The assessment considered historical volumes, existing infrastructure, and feedback from meetings with government officials, planning agencies, and maquiladoras.

4.4 Regional Growth and Development Plans. This section reviewed the regional growth and development plans for El Paso, Ciudad Juarez, and the plans to establish new POEs to verify the suitability of the FSS with the planning objectives of both cities.

4.5 System Configuration Alternatives. This section describes the proposed configuration of the main elements of the FSS system: U.S. and Mexican inspect-inmotion and terminal facilities, as well as the design of proposed routes for the FSS.

4.6 Chapter Summary and Recommendations. Based on the analysis performed, this section summarizes the findings and conclusions of each section, and provides recommendations.

The main parameters considered in our approach are the identification of current industrial clusters; availability of vacant land and transportation infrastructure; and the regional plans. 


\subsection{LOCATION OF POTENTIAL CUSTOMERS}

The FSS was designed to operate in transportation corridors that serve large volumes of freight on a daily basis. In addition to these corridors, commercial POEs that report large volumes of freight through the border represent a great market opportunity for the FSS implementation. There are thirteen operating commercial POEs in Texas having truck-traffic as the dominant mode for trade between the U.S. and Mexico. Laredo is the POE with highest value of trade followed by El Paso; commercial traffic at the Hidalgo and Pharr-Reynosa POE is on the rise (2). This analysis explores the location of potential customers for the FSS in the El PasoCiudad Juarez binational region; at the same time, it provides a framework for the exploration of implementing the FSS concept in other POEs in Texas.

Industrial operations in the El Paso - Ciudad Juarez region are part of a more complex intercontinental supply chain. In general terms, El Paso supports mainly third-party logistics (3PLs) operations, i.e. warehousing, distribution, and supplying raw materials or work-in-process inventory coming from North America, Asia, Europe, Mexico and South America to the maquiladoras in Ciudad Juarez - the manufacturing base. Once the respective transformation procedure is incorporated in the manufacturing base, work-in-process inventory and finished products, mainly, come back to El Paso for warehousing and further distribution inside the U.S.

Most industrial operations are located near the Bridge of the Americas (BOTA) and YsletaZaragoza Ports of Entry (POE) towards the eastern side of both cities. Since the industrial developments on the west side are minimal (concentrated close to the Santa Teresa, New Mexico POE), the location of the FSS target market is on the eastern side of El Paso - Ciudad Juarez binational region (see Figure 6).

The next section illustrates the location of potential customers, in El Paso and then in Ciudad Juarez, grouping them into clusters. 


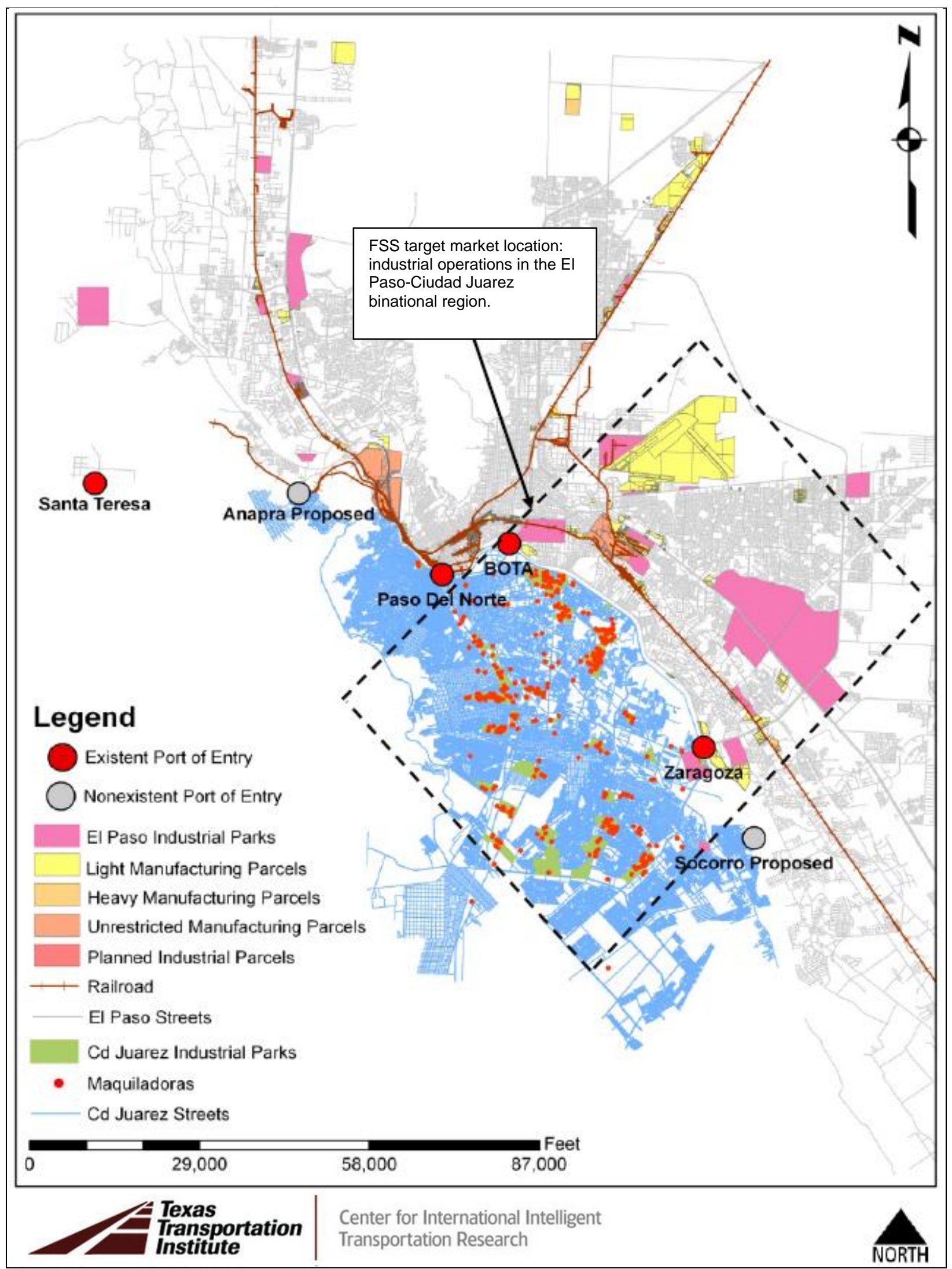

Figure 6. FSS Target-Market Location: Industrial Operations in EI Paso - Cd. Juarez 


\section{El Paso Industrial Cluster Locations}

There are 19 major industrial parks and a total of 295 plants in El Paso (see Table 12), with a vacancy rate of 12.6 percent in 2010 (3). The majority of these industrial parks and plants are located towards the eastern side of the city, and can be easily identified in two main clusters named: ELP-Cluster No.1 and ELP-Cluster No.2 (see Figure 7).

Table 12. Industrial Parks in El Paso

\begin{tabular}{|l|c|l|}
\hline \multicolumn{1}{|c|}{ Industrial Park Name } & $\begin{array}{c}\text { No of } \\
\text { Plants }\end{array}$ & \multicolumn{1}{|c|}{ Location } \\
\hline Pan American Center for Industry & 32 & East \\
\hline Ysleta Industrial Park & 27 & East \\
\hline 10/375 Industrial Park & 26 & East \\
\hline Pendale Industrial Park & 22 & East \\
\hline Vista del Sol Industrial Area East & 21 & East \\
\hline Vista del Sol Industrial Area West & 18 & East \\
\hline Copperfield Industrial Center & 15 & Central-East \\
\hline Eastside Industrial Area & 13 & Central-East \\
\hline Centraplex and Midtown & 12 & Central \\
\hline Airport Industrial Tracts & 11 & East \\
\hline Montana Industrial Park & 10 & East \\
\hline General Lee Industrial Area & 9 & East \\
\hline Sunland Park Industrial Park & 8 & West \\
\hline Butterfield Trail Industrial Park & 7 & Central-East \\
\hline Zack White Industrial Park & 6 & West \\
\hline Miramonte Industrial Park & 5 & West \\
\hline Santa Teresa Industrial Park & 4 & West \\
\hline Northeast Industrial Center & 295 & Northeast \\
\hline Northwestern Corporate Center & & West \\
\hline Outside of an Industrial Park & 24 & - \\
\hline Total Plants in El Paso & 12 & \\
\hline
\end{tabular}

- ELP-Cluster No.1 is the main concentration of industrial parks in El Paso. Industrial operations in this cluster provide support to the automobile, manufacturing, 3PLs, and other operations. This cluster benefits from the proximity to the Ysleta-Zaragoza POE and connectivity to excellent access points (i.e. I-10, Loop-375 and Zaragoza Rd). This cluster offers the advantage of having numerous acres designated as sites from the Foreign-Trade Zone No.68 (FTZ No.68).

- ELP-Cluster No.2 sits in the proximity of El Paso International Airport (EPIA). Industrial operations in this cluster include suppliers to the automotive and health care industries. It provides traditional "twin-plant" users numerous logistical benefits including the proximity to BOTA import and export lots (5.5 miles), the fast access to 
Ysleta-Zaragoza POE through I-10 and Loop-375, and the advantages offered by the FTZ No.68 and EPIA.

Four of the main industrial parks are located in ELP-Cluster No.1 and five in ELP-Cluster No.2 (see Table 13).

Table 13. Location of Industrial Parks per Cluster in El Paso

\begin{tabular}{|l|l|}
\hline \multicolumn{1}{|c|}{ ELP-Cluster No.1 } & \multicolumn{1}{c|}{ ELP-Cluster No.2 } \\
\hline Vista del Sol Industrial Area & Butterfield Trail Industrial Park \\
Pendale Industrial Park & Montana Industrial Park \\
10/375 Industrial Park & Airport Industrial Tracts \\
Pan-American Center for Industries & Eastside Industrial Area \\
Ysleta Industrial Park & Copperfield Industrial Center \\
& Centraplex and Midtown \\
\hline
\end{tabular}

The City of El Paso is the grantee and operator of the FTZ No.68 under the EPIA. The FTZ No.68 provides special customs procedures reducing transaction costs for U.S. companies engaged in international commerce. The zone consists of more than 25 sites containing 3,443 acres spread out mainly through the eastside and central areas (highlighted in green in Figure 7). On average, over 70 firms use the FTZ No.68 handling for more than 200 different items from more than 80 countries. Clearly, this represents a potential market for the FSS.

Since the ability to attract truck-traffic, or customers, is significantly influenced by land use surroundings, Figure 7 also shows which parcels outside the industrial parks have an Industrial land-use classification including: (i) Light Industrial Districts, (ii) Heavy Industrial Districts, (iii) Unrestricted Industrial Districts. The establishment of the FSS terminal will require a parcel with one of the three industrial land-use classifications. 


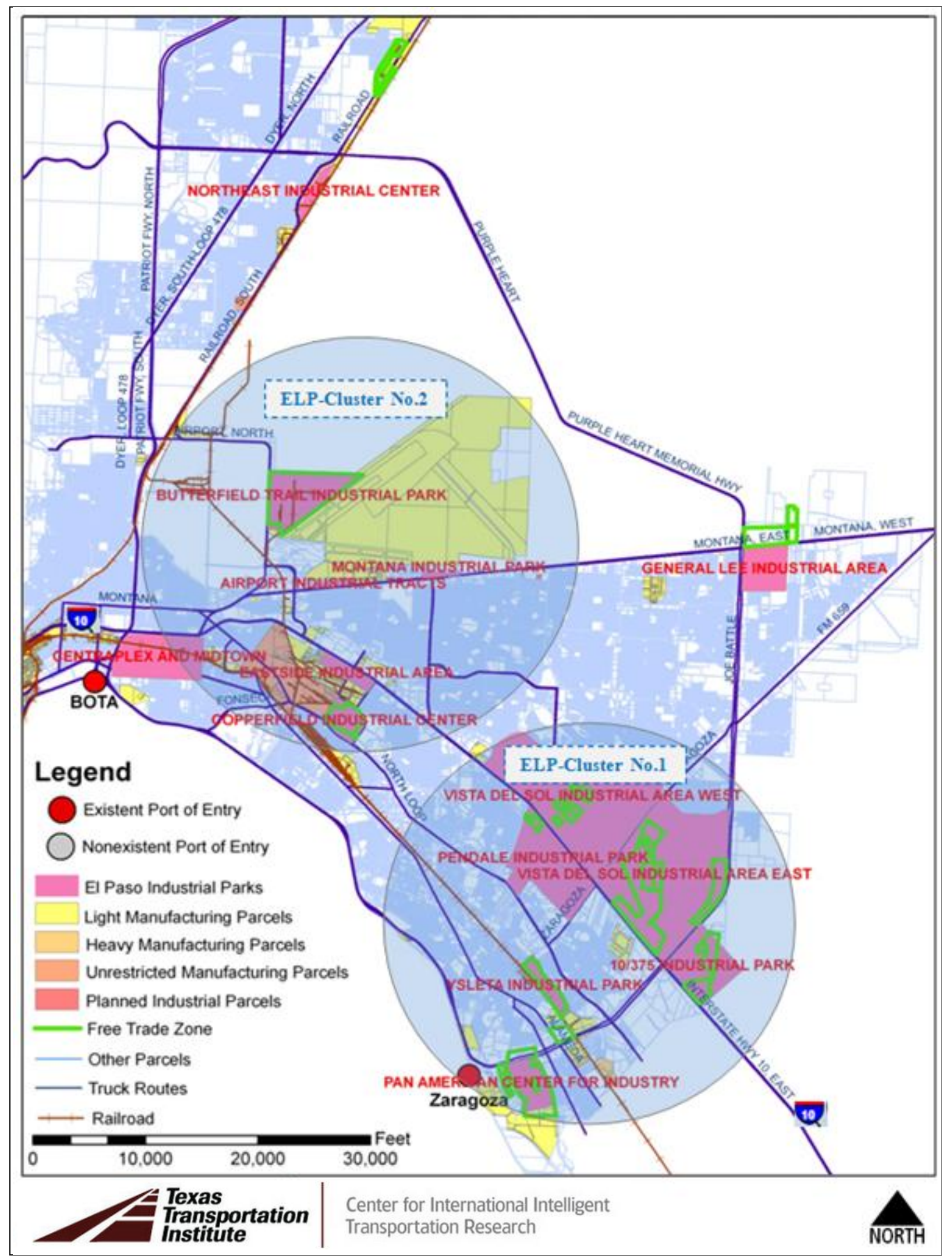

Figure 7. Location of Main Industrial Parks and Industrial Parcels in El Paso 


\section{Ciudad Juarez Industrial Clusters Location}

There are 34 major industrial parks with a total of 348 Maquiladora plants in Ciudad Juarez with a vacancy rate of $12 \%$ in 2010 (4) (see Table 14). Industrial operations in Ciudad Juarez are spread all over the city.

Table 14. Industrial Parks in Ciudad Juarez.

\begin{tabular}{|l|c|c|}
\hline \multicolumn{1}{|c|}{ Industrial Park Name } & No of Plants & Location \\
\hline Altavista & 3 & West \\
\hline Omega & 34 & Center \\
\hline Los Fuentes & 15 & Center \\
\hline Antonio Bermudez & 52 & East \\
\hline Eje Juan Gabriel & 13 & West \\
\hline Juarez & 15 & West \\
\hline Ramon R Lara & 17 & Center \\
\hline Fernandez & 10 & West \\
\hline Gema I & 10 & West \\
\hline Gema II & 3 & West \\
\hline Aztecas & 12 & West \\
\hline Las Lomas & 6 & East \\
\hline Rio Bravo & 15 & East \\
\hline ABH & 1 & East \\
\hline Zaragoza & 7 & South \\
\hline North Gate & 4 & West \\
\hline Henequen & 8 & East \\
\hline Aeropuerto & 11 & Southwest \\
\hline P-Intermex & 23 & East \\
\hline Aerojuarez & 6 & South \\
\hline Panamericano & 8 & West \\
\hline Torres Sur & 8 & Southeast \\
\hline Los Bravos & 0 & Southeast \\
\hline Axial & 15 & South \\
\hline Salvarcar & 1 & East \\
\hline Centro Ind. Juarez & 7 & Southeast \\
\hline Americas & 348 & South \\
\hline Zona Ind. Thomson & & East \\
\hline Outside of an Industrial Park & 1 & - \\
\hline Total Maquiladoras & & \\
\hline
\end{tabular}

Since a visual analysis did not reveal any specific clusters, a more detailed approach was used to identify the clusters (centroids) of maquiladoras. Using the "Mean Store Center" function in ArcGIS Business Analyst, three centroids were calculated using the mean geographic center of all maquiladoras in Ciudad Juarez; the centroids represent a geographic balance point between all customers. Three centroids were calculated for all the maquiladoras (red dots) in Ciudad Juarez; these could be located within or outside of an industrial park (dark green). As a result, maquiladoras were grouped in three clusters: CDJ-Cluster No.1, CDJ-Cluster No.2, and CDJ- 
Cluster No.3. Furthermore, a one mile radius was used as a potential capture zone for each cluster, shown in blue circles (see Figure 8).

- CDJ-Cluster No.1 is centrally located in the north of the city very close to the BOTA in the proximity of the U.S.-Mexico border. This cluster includes four industrial parks and other maquiladoras outside industrial parks to account for a total 108 maquiladoras within the cluster. It benefits from the proximity to the BOTA import and export lots; however, the mix of trucks and passenger cars, along with school zones in its proximity, generate numerous traffic problems during rush hours.

- CDJ-Cluster No.2 is positioned over the Eje Vial Juan Gabriel in the west side of Ciudad Juarez, a main artery that crosses the entire city in the north-south direction. This cluster includes nine industrial parks and few maquiladoras outside industrial parks to account for a total 90 maquiladoras within the cluster. It benefits from good connectivity and its proximity to the International Airport Benito Juarez. The Eje Vial Juan Gabriel runs parallel and very close to the railroad track. It is heavily dense.

- CDJ-Cluster No.3 is the main and most recent concentration of industrial parks and maquiladoras in Ciudad Juarez. This cluster is located towards the Southeast and eastern parts of the city. Seventeen industrial parks fall within this cluster enclosing around 130 maquiladoras. It benefits from the proximity to the Ysleta-Zaragoza POE and connectivity to excellent access points.

Five of the main industrial parks are located in CDJ-Cluster No.1, nine in CDJ-Cluster No.2, and seventeen in CDJ-Cluster No.3 (see Table 15).

Table 15. Location of Industrial Parks per Cluster in Ciudad Juarez

\begin{tabular}{|c|c|c|c|c|c|}
\hline CDJ-Cluster No.1 & CDJ-Cluster No.2 & \multicolumn{3}{|c|}{ CDJ-Cluster No.3 } & \\
\hline Omega & Eje J. Gabriel & Aztecas & Rio Bravo & Aeropuerto & Axial \\
Los Fuentes & Juarez & Johnson & ABH & P-Intermex & Salvarcar \\
Antonio Bermudez & Ramon R. Lara & LG & Zaragoza & Aerojuarez & Juarez \\
Lear Corporation & Fernandez & Gema II & Las Lomas & Panamericano & Americas \\
Omega & Gema I & & North Gate & Torres Sur & Thomson \\
& & & Henequen & Los Bavos & \\
\hline
\end{tabular}

It was not possible to identify land uses planned for industrial uses in Ciudad Juarez. 


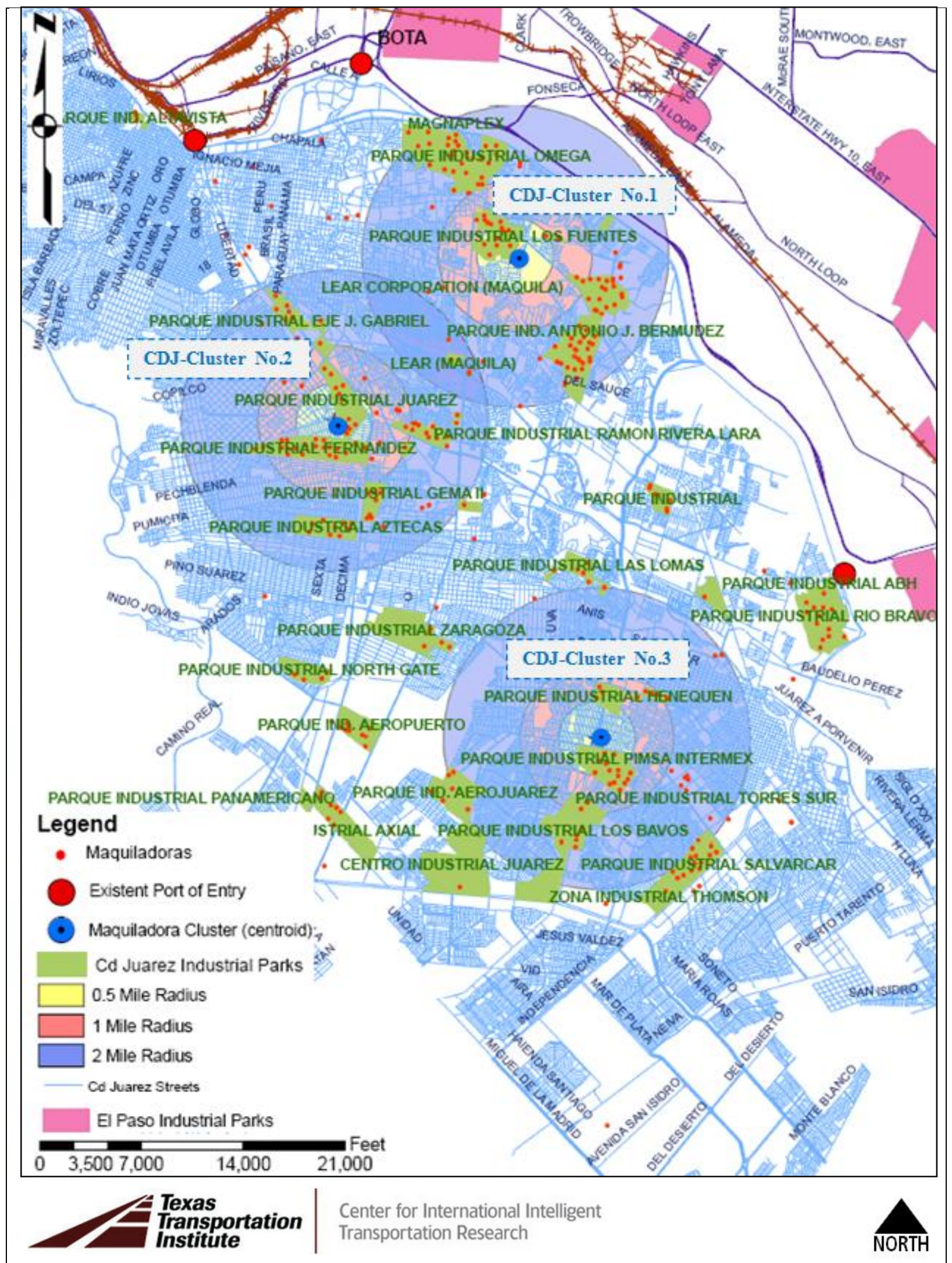

Figure 8. Location of Main Industrial Parks and Maquiladoras in Ciudad Juarez 


\subsection{BORDER-CROSSING ANALYSIS}

In order to determine a feasible border crossing alternative for the FSS, all POEs in the El Paso - Ciudad Juarez region were considered in our analysis; however, this section presents only the most viable alternative: the Ysleta-Zaragoza POE. In addition to the customers' location, this conclusion is supported throughout the rest of this chapter with the assessments of existing practices, regional growth and development plans, as well as visually in the system configuration alternatives. Existing practices were documented based on a combination of historical volumes for each POE and several meetings with stakeholders and maquiladoras to determine which POEs are most frequently used by the industries and identify the main drivers for POE-selection (a comprehensive stakeholder analysis is presented in Chapter 6).

Regional growth and development plans for El Paso and Ciudad Juarez were explored to identify areas and land uses reserved for urban growth; moreover, long-term plans to manage truck traffic were explored. Finally, the availability of enough vacant land and rights-of-way (ROW) in contiguous areas to each POE played a significant role in the selection. The availability of vacant land and such plans were complemented by conducting meetings with pertinent government officials and planning agencies, as well as maquiladoras. (For the analysis of BOTA and Santa Teresa see Appendix B).

\section{Existing Practices}

Historically, the border-crossing volumes have been quite balanced between BOTA and Ysleta-Zaragoza POE in the range of 200,000 to 450,000 trucks per year (see Figure 9). The Santa Teresa POE carries significantly lower volumes, in the range of the 30,000-50,000 trucks per year.

A general consensus exist among the interviewees that Ysleta-Zaragoza is the preferred POE. Four main factors play a significant role in the decision of POE-selection for every shipment: (i) origin-destination; (ii) crossing-time, including congestion and delays; (iii) schedule of operations; and (iv) the availability of Free and Secure Trade (FAST) lanes ${ }^{1}$. Since the FSS will not experience congestion or delays and it's expected to operate 24 hours a day, the main driver for the ranking of border crossing alternatives was the origin-destination pairs between the three maquiladora clusters in Ciudad Juarez and the two clusters in El Paso.

Overall, northbound truck traffic at both commercial crossings in El Paso peaks between 10:00 am and 12:00 pm. During the early hours of the day, empty trucks cross northbound through BOTA to pick up loads or raw materials for maquiladora assembly plants. Even before BOTA closes commercial operations, some traffic voluntarily diverts to Ysleta-Zaragoza, causing a period of high demand at around 5:00 pm. Around 7:00 pm, loaded vehicles create another period of high demand at the Zaragoza facility. These afternoon peaks result from

\footnotetext{
${ }^{1}$ The Free and Secure Trade (FAST) program is a pre-clearance program for known low risk shipments from Canada and Mexico. Initiated after 9/11, this innovative program allows for expedited processing for trusted shippers who have completed background checks. Key benefits of FAST enrollment are: access to dedicated lanes for greater efficiency in the processing of transborder shipments; reduced number of inspections and delays at the border; and enhanced supply chain security protecting the economic prosperity of the U.S., Canada and Mexico.
} 
shipments that leave Mexican maquiladoras at the end of the second manufacturing production shift. Although the Ysleta-Zaragoza POE offers longer hours for commercial operations, BOTA processes more trucks per day. This is due to the absence of a toll at BOTA (compared to the \$10 toll at Ysleta) and the higher number of empty trucks, which are processed faster than the laden vehicles (5).

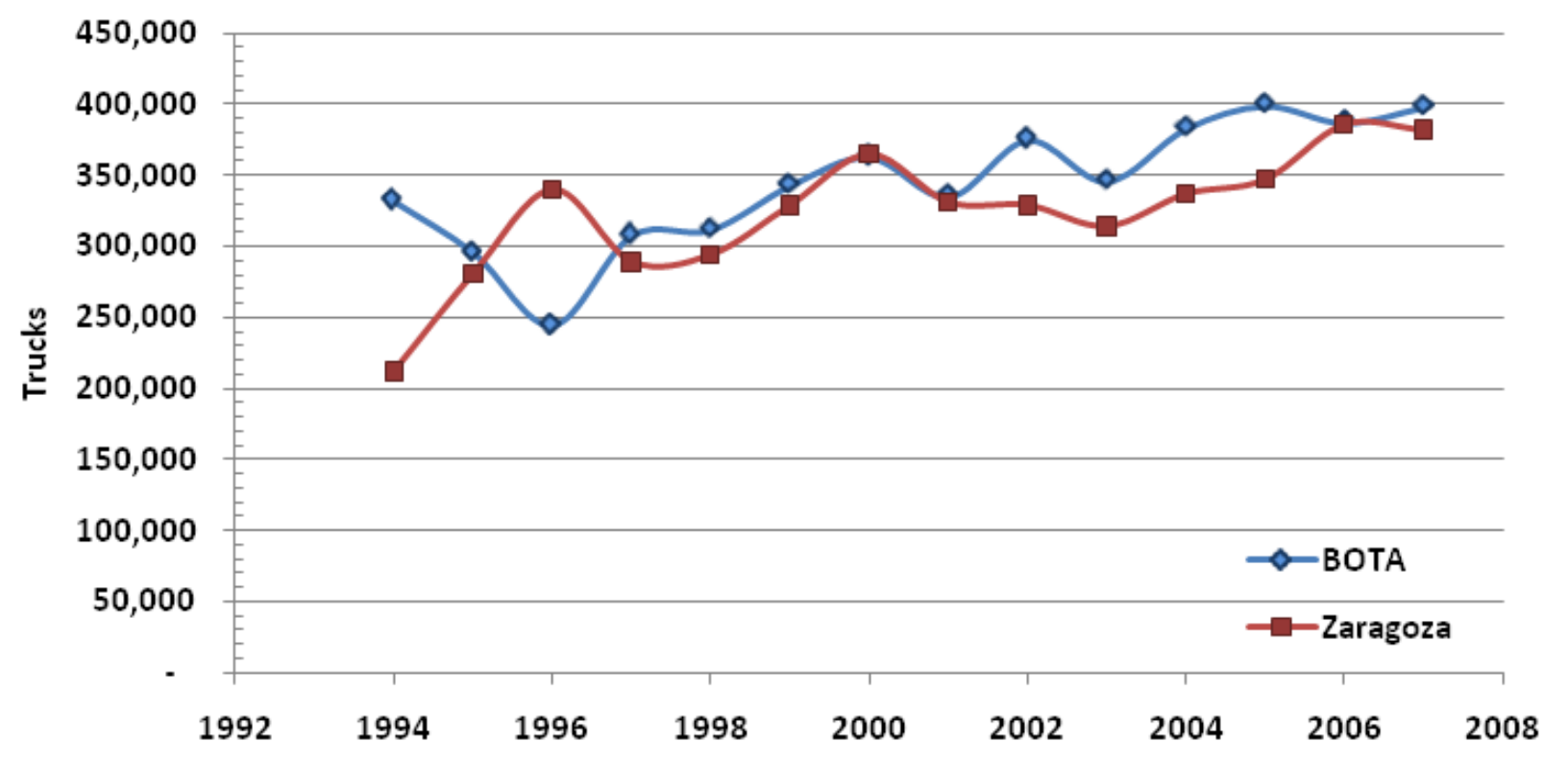

Figure 9. Historical Truck Volumes for BOTA and Zaragoza Ports of Entry

The supply chain manager of each maquiladora is the decision-maker regarding the POEselection, not the trucking company. In general terms, the considerations for the selection of a specific POE include:

- some supply chain managers have predefined routes to access each POE, with videosurveillance along each route, restricting trucking companies to only predefined routes;

- there is preference to use BOTA because communication with Customs is better than in other POEs - this facilitates solving administrative problems (to liberate shipments that couldn't cross);

- there is a preference to avoid the Santa Teresa POE because of the number of Mexican-Army checkpoints along its route (checkpoints generate significant delay);

- the manager selects a POE based on truck-route congestion combined with inspections delay times;

- the manager selects a POE based on the schedule of operations in each POE, when BOTA closes they use Zaragoza-BOTA closes at 6:00 pm but trucks after 4:00 pm carry significant risk of not crossing;

- the availability of FAST-Lanes (Santa Teresa doesn't have FAST, so some managers avoid it); and

- the proximity to the POE and to the origin or destination. 
Cost per drayage shipment does not influence the POE-selection and is very uniform independently of the POE - different from the "cost of a delayed shipment" - which is very significant for a maquiladora, as retailers and distributors impose penalties on delayed shipments.

\section{Ysleta-Zaragoza Bridge}

The Ysleta-Zaragoza POE consists of two separate structures: (i) a four-lane bridge for commercial traffic, which includes two sidewalks for pedestrian crossing and (ii) a five-lane bridge for noncommercial traffic (see Figure 10).

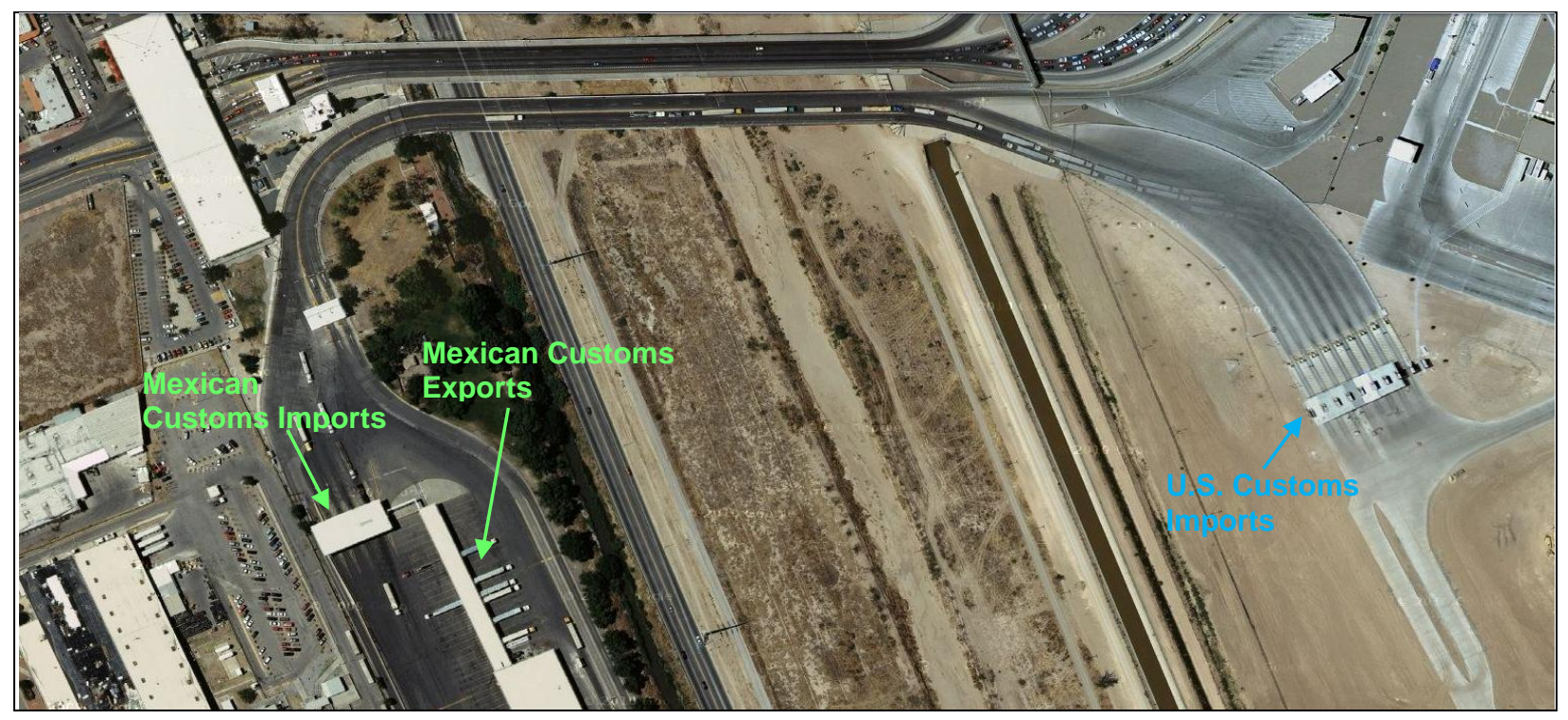

Figure 10. Aerial Image of the Ysleta-Zaragoza POE

The City of El Paso is the owner of the bridge on the US side. The General Services Administration (GSA) owns the border station and 61 acres of land area; the City operates truck tollbooths on GSA property. The Mexican owner is the Government of Mexico, and the operator is Caminos y Puentes Federales (CAPUFE); however, Promofront S.A. de C.V. has the concession until 2017. The schedule for commercial traffic is from 6:00 am to 12:00 am from Monday thru Friday and from 8:00 am to 4:00 pm on Saturdays; Sundays it is closed. The tolls at the Ysleta-Zaragoza POE are US \$3.50 per axle of commercial traffic, as of January 1, 2011 (6). The City of El Paso upgraded the toll collection system in January 2007 and expanded the southbound toll lanes from six to eight lanes. Such expansion did not require a new application for a presidential permit, only an amendment to the existent permit (7).

There are Customs, Immigration, and Agricultural inspections performed on both sides of the border. A FAST lane opened in June 2004. Two additional lanes became operational in October 2008 totaling three FAST lanes. The new facilities included the expansion of commercial lanes from six to eight with the ability to add two additional lanes in the future; an x-ray machine at one of the lanes to allow empty trucks to be reviewed quickly without having to go to secondary inspection; and updated radiation monitors. Additionally, the North American Trade Automation Prototype dedicated shortrange testing equipment was installed in July 1997 (7). 
From the interviewed supply chain managers, there is a general perception that existing infrastructure conditions at the POEs are not efficient. Frequently, the truckers experience bottlenecks at the POEs. Existing infrastructure doesn't allow efficient segregation of the trucks in the FAST program from trucks not in the program; also some truckers intentionally block FAST lanes. Moreover, the modules at the POEs sometimes are not operating to full capacity. Current Mexican regulations require cargo inspections for imports and exports to be performed exclusively at the border POE. This would require the location of inspections terminals for the FSS-cargo at the border rather than in the terminals. Consequently, we will explore land availability in the POE proximity on both sides of the border.

\section{Connecting Roadways}

The Ysleta-Zaragoza POE is well connected on both sides of the border. In the U.S. two major arteries serve international trade: (i) the State Loop 375 or Cesar Chavez Border Highway and (ii) the Americas Ave, which connect to I-10. The access roads to the bridge are both state and city owned. In Mexico, a state road connects to Mexican Highway 2 (MEX-2) and continues to Mexican Highway 45 (MEX-45); additional access roads to the POE are owned by the municipality of Ciudad Juarez. Recently, the Boulevard Francisco Villarreal that connects MEX-45 with MEX-2 was modernized; moreover, the Boulevard 4 Siglos or Juan Pablo II was modernized providing a direct connection, parallel to the border, from the Ysleta-Zaragoza Port of Entry to the BOTA port of entry and to all the industrial parks and maquiladoras located in CDJ-Cluster No1 (see Figure 11).

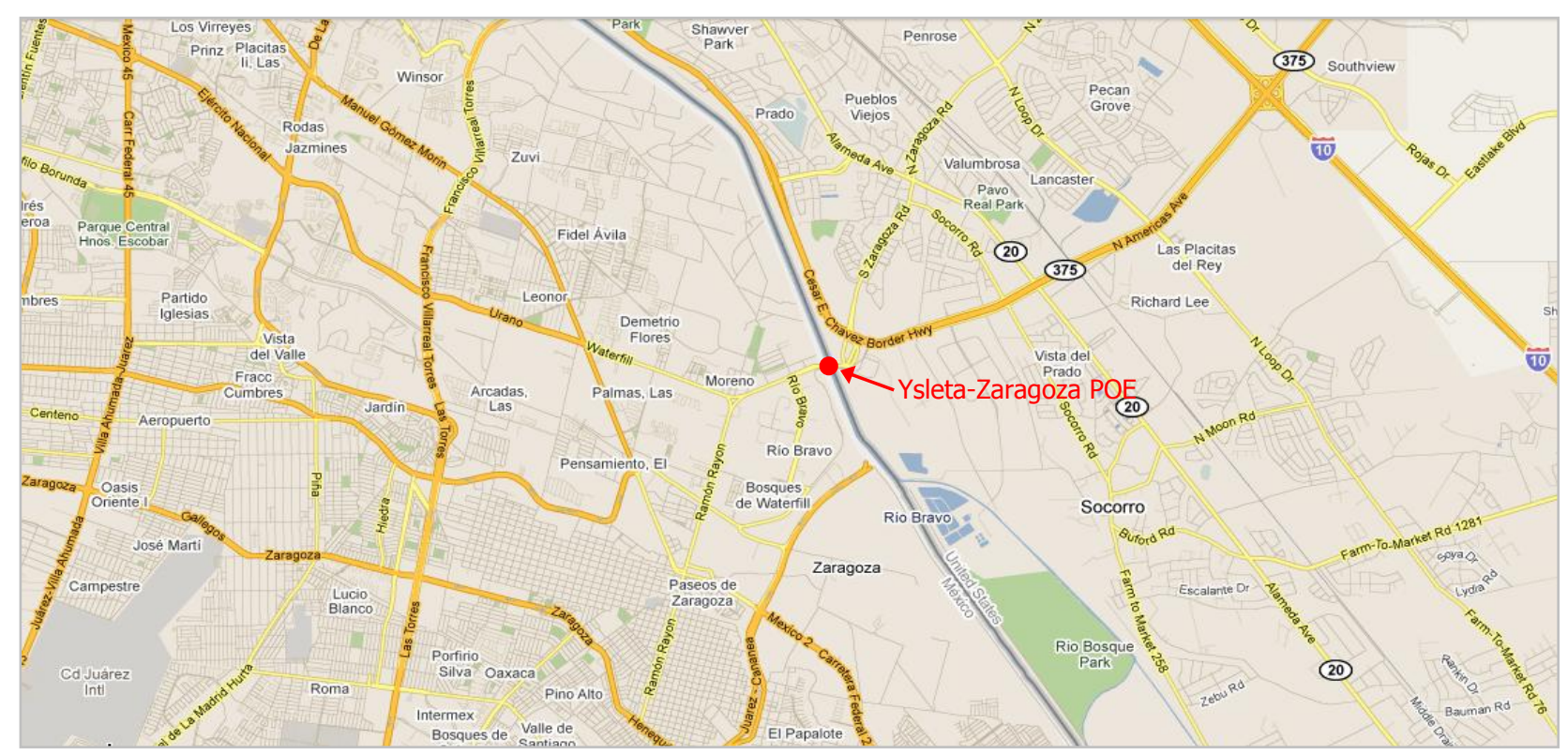

Figure 11. Ysleta-Zaragoza Port of Entry Roadways-FSS Proposed Border-Crossing

\subsection{REGIONAL GROWTH AND DEVELOPMENT PLANS}

Meetings and interviews were conducted with the regional planning organizations in El Paso and Ciudad Juarez to introduce them the FSS concept. The regional growth and development 
plans for both cities were revised to ensure that the FSS concept was in-line with the plans of both cities, and to explore the most efficient way to integrate the binational concept.

\section{City of El Paso Regional Plans}

In addition to interviews conducted with pertinent officials, the following documents were revised to ensure that the FSS project does not interfere with the short, medium and long-term regional plans of the City of El Paso, including:

- 2008 Comprehensive Mobility Plan for the City of El Paso (CMP)

- Mission 2011-2014 Transportation Improvement Program (TIP)

- Mission 2035 Metropolitan Transportation Plan (MTP)

- El Paso Regional Growth Management Plan

- El Paso International Airport Master Plan Update

- City of El Paso Sustainability Program

- $\quad$ The Plan for El Paso 1999

\section{Summary of Findings}

The assessment indicates that the objectives of a binational implementation of the FSS project are consistent with the goals of the TxDOT, the City of El Paso, and the Camino Real Regional Mobility Authority (CRRMA), as part of their long range strategic plans in the metropolitan area of El Paso. Other than interfering, the FSS contributes to their planning objectives primarily by cultivating environmental and economic benefits in the region assisting the City of El Paso to promote sustainability, and attract new investments by increasing efficiency at the POEs; simultaneously, this project could serve as example to modernize other POEs in the nation.

- Two projects included in the CMP and TIP could impact the availability of ROW to place the columns and guideway system for the FSS; similarly, any construction of elevated structures in adjacent areas to the FSS project might impact the design of the FSS elevated guideway.

○ The César Chávez Border Highway is on Loop 375 from US 54 to S Zaragoza $\mathrm{Rd}$ in the proximities of the Ysleta-Zaragoza POE; currently consists of two lanes in each direction. TxDOT is studying a proposed project to rehabilitate the four existing lanes, and create two managed toll lanes in the center of the corridor inside the current lanes (8).

- A second project, Project 14 b on Loop 375 from Zaragoza to I-10, includes the addition of two express toll lanes, one in each direction. Existing access points to Loop 375 are located at S Zaragoza Rd, FM 258 (Socorro Road), FM 76 (North Loop Drive) and I-10. The managed lanes would be located inside of the existing general purpose lanes (8). 
- Several long term projects included in the MTP could have a small impact on the level of expected traffic for the FSS, these include: the Ysleta-Zaragoza POE commercial lane improvements; the Guadalupe-Tornillo POE; the Santa Teresa POE Intelligent Transportation System improvements; the Santa Teresa intermodal rail station; and railroad overpasses as well as truck road infrastructure.

- Discussions have taken place about establishing an international rail crossing through Mexico and New Mexico. NMDOT will build a refueling station for freight trains in the short term, which is anticipated to become an intermodal rail station before 2015 .

- As part of its environmental justice mitigation process, in the planning and programming of projects, the MTP considers all stakeholders that could have a potential impact (i.e. historic districts, monuments, tribal lands, etc.). The Ysleta del Sur Pueblo is a U.S. federally recognized Native American tribe and sovereign nation; their primary reservation is one mile north-east of the Ysleta-Zaragoza POE. A total of 3,213 acres of Ysleta del Sur Pueblo land is held in trust for the tribe by the U.S. Department of the Interior (9). The FSS proposed alternatives are not expected to be located or to have any impact on the Ysleta del Sur Pueblo and their lands; however, such lands are near the proposed configurations.

- The El Paso Regional Growth Management Plan revealed two proposed projects for bridges, overpasses, or interchanges on Zaragoza Rd in the proximities of the YsletaZaragoza POE (10).

- The City of El Paso is in the process of buying land in the Northeast study area for automotive, aerospace, or any industry that would require land to start operations in El Paso. This could represent a viable option for a second terminal location - the City of El Paso would need to know in advance if interest exists to locate in the Northeast area.

- In the vacant land east of EPIA, the airport master plan considers the construction of new facilities for general aviation including a new runway; the exhaustion of almost all vacant land (11). In 2010, EPIA has finished the development of additional air cargo facilities. This development included two 144,000 square foot Air Cargo buildings, over 34 acres of aircraft parking and 6.4 miles of roadways. The cargo complex has an occupancy rate close to 70 percent and is the only modern air cargo complex on the border with immediate expansion capabilities (12). A remaining vacant parcel in the proximities of EPIA could be a viable alternative for a secondary FSS terminal serving the airport.

\section{Plans for New Ports of Entry}

The plans for new ports of entry currently in discussion include: the Anapra, the Socorro, shown in gray circles as "non-existent or proposed POE"; the Yarbrough POE (not discussed since it would exclude commercial traffic); and the Tornillo/Guadalupe POE in Fabens. In March 2005, El Paso County received a Presidential Permit for the construction of a new POE at Fabens. The new POE will be 1,274 feet long and 94 feet wide and will have six vehicular lanes and two pedestrian crossings. El Paso County will obtain 270 acres of adjacent vacant land. The Tornillo/Guadalupe 
$\mathrm{POE}$ at Fabens could represent a viable alternative in the long run; as new industrial developments take place near this POE (see Figure 12).

It was advised that to expedite the process of establishing the FSS border crossing infrastructure, it would offer more advantages to use an existing POE. The entire process of building a new POE might take close to 10 years, but the process of adding new infrastructure to an existing POE might take from 3 to 5 years and is a much more simple procedure. Also, the governance model for this system could follow a similar structure to the one currently operating in the Paso Del Norte or the Ysleta-Zaragoza POE.

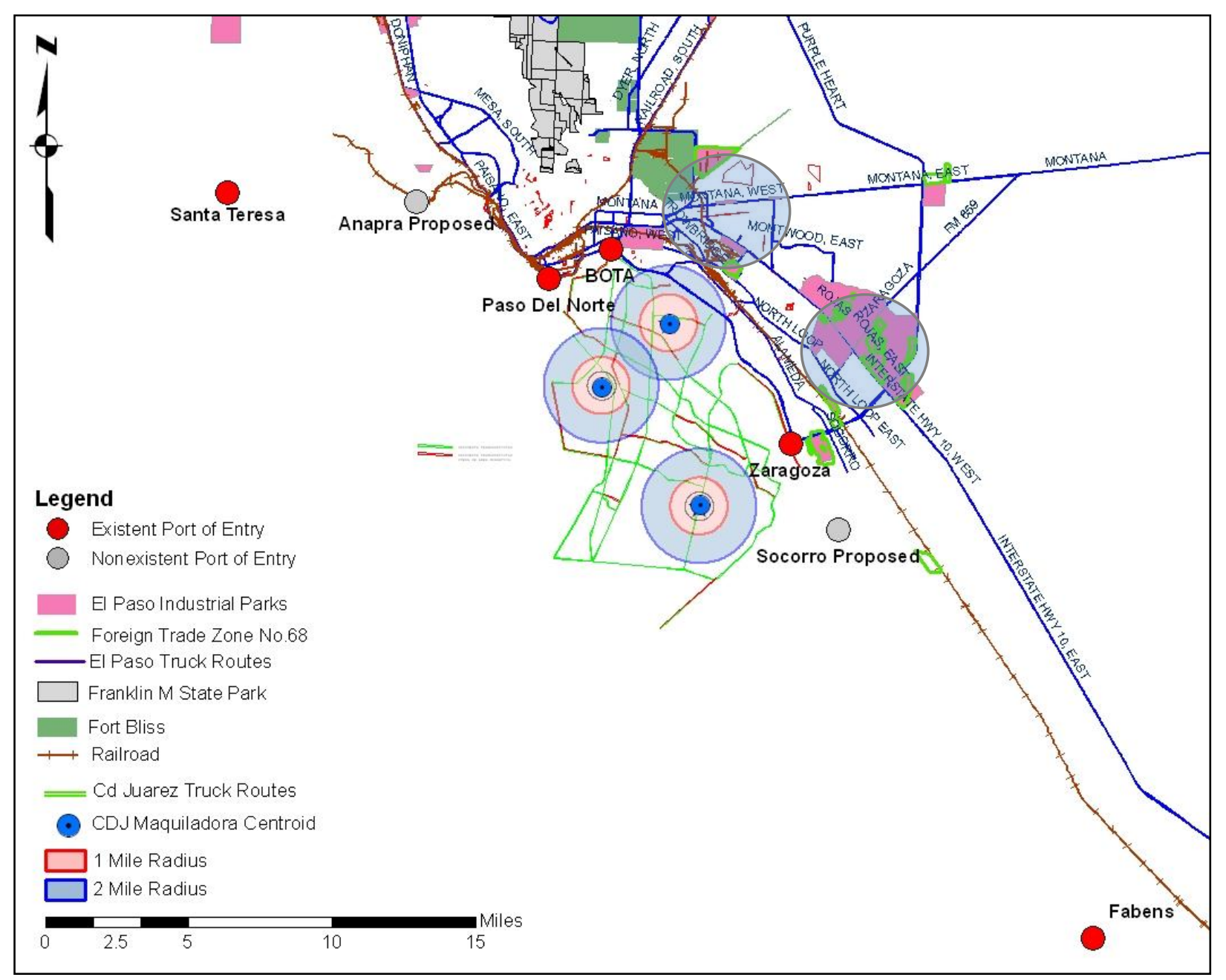

Figure 12. Existing and Proposed Ports of Entry

\section{Ciudad Juarez Regional Plans}

TTI conducted interviews with the regional planning organizations in Ciudad Juarez. Currently, IMIP is against the construction of new bridges, overpasses, or elevated infrastructure in Ciudad Juarez, for considering them esthetically unpleasing and for the lack of technical and financial capabilities for proper maintenance. There are also plans to eliminate trucks-access from Ave Tecnologico, the westernmost portion of Eje Vial Juan Gabriel, and divert truck traffic to Ave 
Independencia and Juan Pablo II Blvd to encourage the use of Zaragoza and reduce the number of trucks in the arteries near BOTA.

In addition to the interviews, the 2009 Regional Development Plan of Ciudad Juarez incorporates several urban areas that are already planned considering future land uses and the type of activities that will be taking place. Such areas are in an initial growth stage, but there are already estimates of the population that might inhabit in three major areas: Oriente XXI 1 y $2^{\mathrm{a}}$ etapa; San Isidro Zaragoza; and San Jeronimo. Some portions of these zones are already part of the city limits of Juarez; nonetheless, they have received special treatment as areas of urban growth adding up to 19,205 hectares (13). This implies that growth will be directed towards the south-eastern side of Ciudad Juarez, and it will be restricted to the west, with exception of the San Jeronimo reserve already approved very near to the Santa Teresa-San Jeronimo POE; growth along the Carretera Casas Grandes highway will be also restricted (see Figure 13).

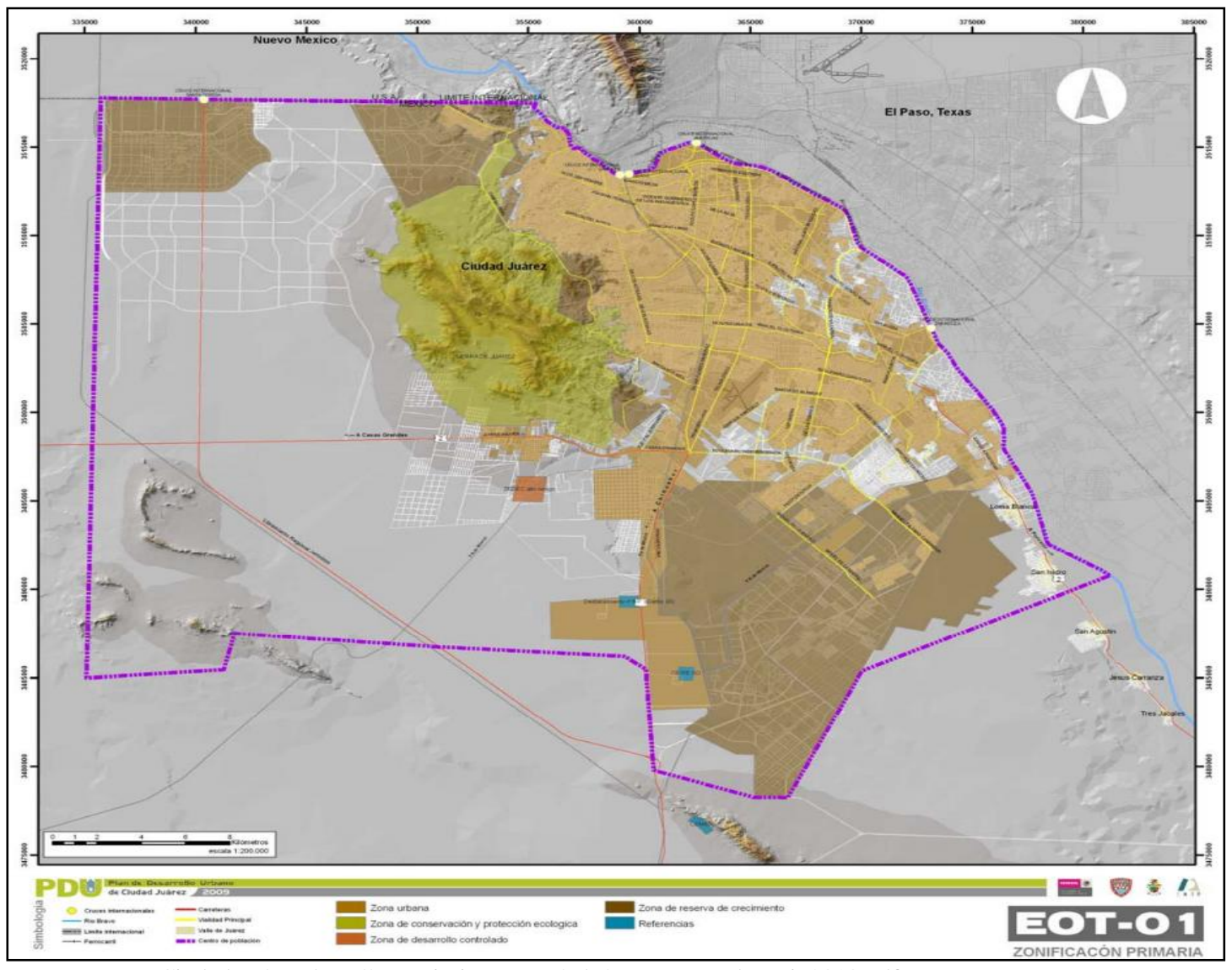

Source: IMIP. Ciudad Juárez. http://www.imip.org.mx/pdu/PDUIntegradoJunio2010.pdf

Figure 13. Ciudad Juarez Urban Zones and Land Reserved for Urban Growth 


\subsection{SYSTEM CONFIGURATION ALTERNATIVES}

The proposed FSS system, for implementation in a binational setting, must consider at least four components:

i. Terminal Facilities on the Mexican side,

ii. Mexican inspect-in-motion facilities,

iii. U.S. inspect-in-motion facilities, and

iv. Terminal Facilities on the U.S. side.

These four components could have multiple configuration alternatives (e.g. locating the inspect-in-motion facilities within the terminal facilities eliminating the need for additional land for inspect-in-motion facilities). As a conservative measure to ensure land availability, this section considers that the inspect-in-motion facility would be located close to the YsletaZaragoza POE. In case the inspect-in-motion facilities are located within each terminal, this analysis considers enough vacant land in the areas adjacent to the terminals.

This section presents three potential terminal locations in El Paso and three in Ciudad Juarez. All FSS routes were created to connect through the Ysleta-Zaragoza POE. Complete system configuration alternatives are created combining a proposed terminal and route in El Paso with a proposed terminal and route in Ciudad Juarez. All proposed terminals and routes are presented individually in this section, first for El Paso and then for Ciudad Juarez. However, only the three most viable system configuration alternatives, named Alternative 1,2 and 3, are evaluated in the financial model in Chapter 7 (see Table 16).

Table 16. FSS System Configuration Alternatives

\begin{tabular}{|c|c|c|c|c|c|c|}
\hline $\begin{array}{c}\text { FSS System } \\
\text { Configuration } \\
\text { Alternative }\end{array}$ & $\begin{array}{c}\text { El Paso } \\
\text { Terminal and } \\
\text { Routes }\end{array}$ & $\begin{array}{c}\text { El Paso } \\
\text { ROW (miles) }\end{array}$ & $\begin{array}{c}\text { Cd. Juarez } \\
\text { Terminal and } \\
\text { Routes }\end{array}$ & $\begin{array}{c}\text { Cd. Juarez } \\
\text { ROW (miles) }\end{array}$ & $\begin{array}{c}\text { FSS Cross- } \\
\text { border Link } \\
\text { (miles) }\end{array}$ & $\begin{array}{c}\text { Total } \\
\text { Route } \\
\text { (miles) }\end{array}$ \\
\hline Alternative 1 & ELP Route 1 & 0.717 & CDJ Route 1 & 6.476 & 0.923 & 8.116 \\
\hline Alternative 2 & ELP Route 1 & 0.717 & CDJ Route 2 & 7.395 & 0.923 & 9.035 \\
\hline Alternative 3 & ELP Route 2 & 2.929 & CDJ Route 1 & 6.476 & 0.923 & 10.328 \\
\hline Alternative 4 & ELP Route 2 & 2.929 & CDJ Route 2 & 7.395 & 0.923 & 11.247 \\
\hline Alternative 5 & ELP Route 3 & 4.599 & CDJ Route 1 & 6.476 & 0.923 & 11.998 \\
\hline Alternative 6 & ELP Route 3 & 4.599 & CDJ Route 2 & 7.395 & 0.923 & 12.917 \\
\hline Alternative 7 & ELP Route 1 & 0.717 & CDJ Route 3 & 15.341 & 0.923 & 16.981 \\
\hline Alternative 8 & ELP Route 2 & 2.929 & CDJ Route 3 & 15.341 & 0.923 & 19.193 \\
\hline Alternative 9 & ELP Route 3 & 4.599 & CDJ Route 3 & 15.341 & 0.923 & 20.863 \\
\hline
\end{tabular}

First, an overview of the three alternatives in El Paso is presented. The three proposed terminal facilities are illustrated in orange, red and pink, each of them connected to the proposed inspect-in-motion facility in blue; subsequently, this inspect-in-motion facility is connected to a FSS Cross-border link, which crosses the border through the Ysleta-Zaragoza international bridge, and connects to the inspect-in motion facility on the Mexican side, in green (see Figure 14). 
Subsequently, from the inspect-in motion facility on the Mexican side, in green, the three alternatives for terminal facilities in Ciudad Juarez are illustrated in orange, red and pink, respectively on the Mexican side (see Figure 15). The FSS Cross-border link, the inspect-inmotion alternatives, and all the proposed terminal alternatives are explored and illustrated individually in subsequent figures. This assessment do not attempts to represent the final track configuration of the entire routes. The location of all pedestrian and highway grade crossings to be removed, grade separated, or to remain in use was assessed using aerial imagery. 


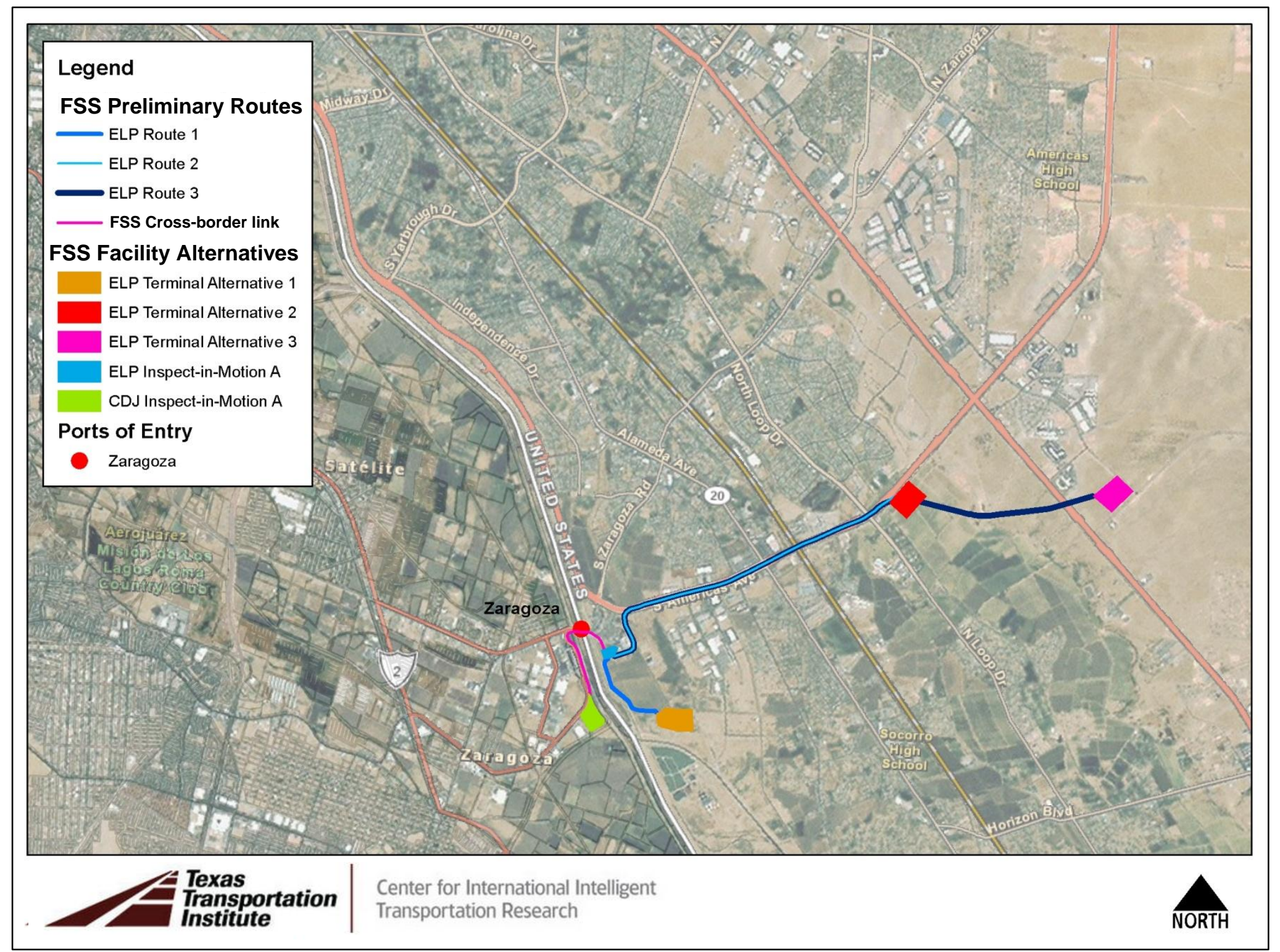

Figure 14. Alternatives for System Configuration for El Paso Terminals 


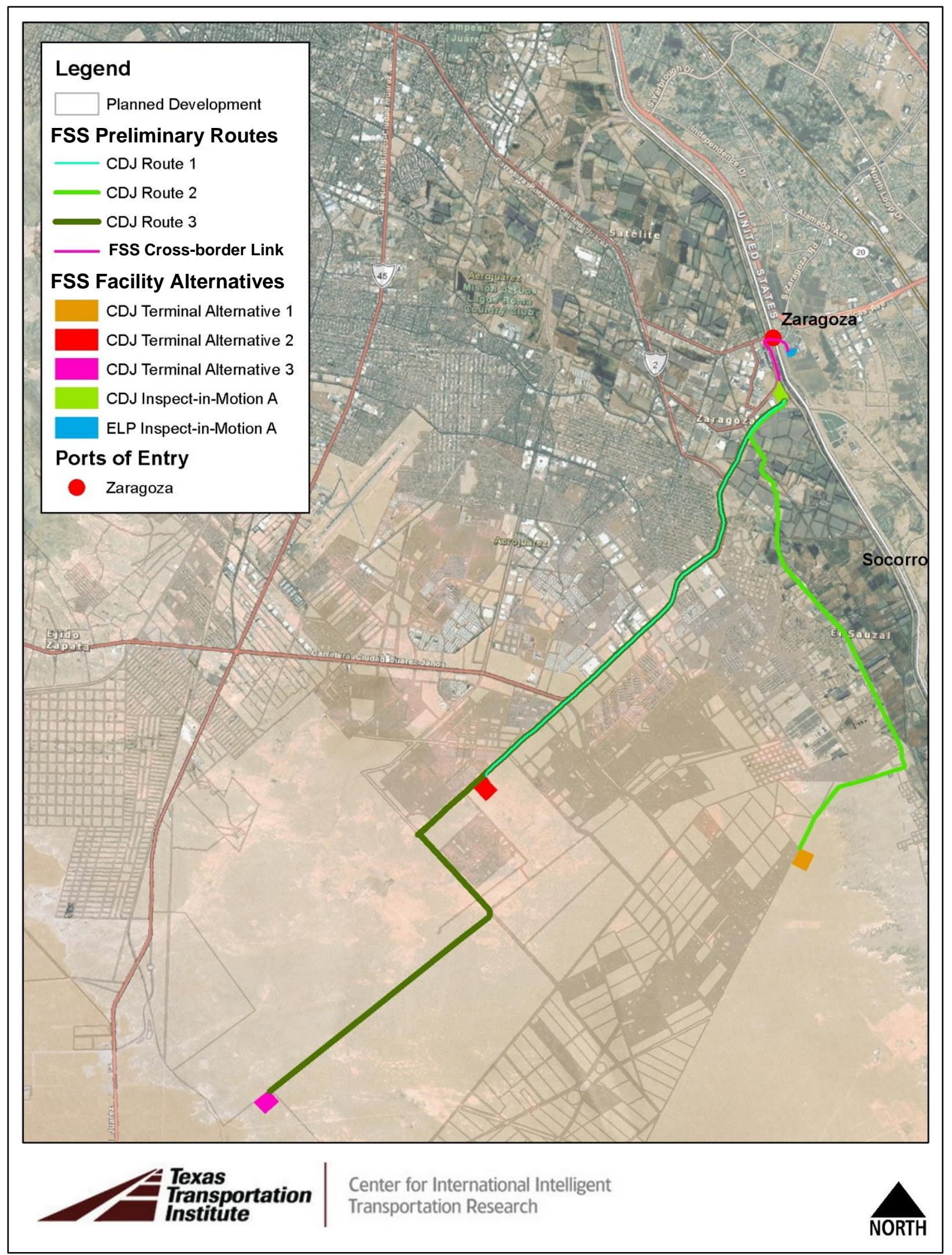

Figure 15. Alternatives for System Configuration for Ciudad Juarez Terminals 


\section{The FSS Cross-Border Link}

Since the Ysleta-Zaragoza POE represents the most viable border-crossing alternative, a crossborder link was designed following visible available ROW adjacent to the structure for commercial traffic. Such a link is expected to provide available space to allow for placement of the columns, from 4 to six feet wide, which will support the guideways of the system. The FSS cross-border link will remain unchanged for all the route alternatives for the configuration of the system, and is illustrated with a pink line (see Figure 16).

\section{Alternative Inspect-in-Motion Facilities}

In the case that legal challenges or any other operational impediments hamper the establishment of the inspect-in-motion facilities within each of the FSS proposed terminals (e.g. the inability to make changes to the Mexican federal regulation mandating that the inspections should be conducted at the POE), this section presents an assessment of the viability of having the inspect-in-motion facilities within the ports of entry on both sides of the border.

Two alternatives were identified in El Paso and only one in Ciudad Juarez. El Paso Inspectin-Motion Facility A is connected to the Ciudad Juarez Inspect-in-Motion Facility A through the FSS cross-border link; blue and green polygons respectively (see Figure 16); this alternative is the one used to explore each route individually. The current owner of the parcel is listed in parcel data as the United States of America.

El Paso Inspect-in-Motion Facility B also connects to the Ciudad Juarez Inspect-in-Motion Facility $A$ through the FSS cross-border link, but would require a 0.214 mile extension of that link (see Figure 17); this alternative is only illustrative and is not used throughout the remaining analyzes. The current owner of the parcel is the F-Star Zaragosa Port LLC. 


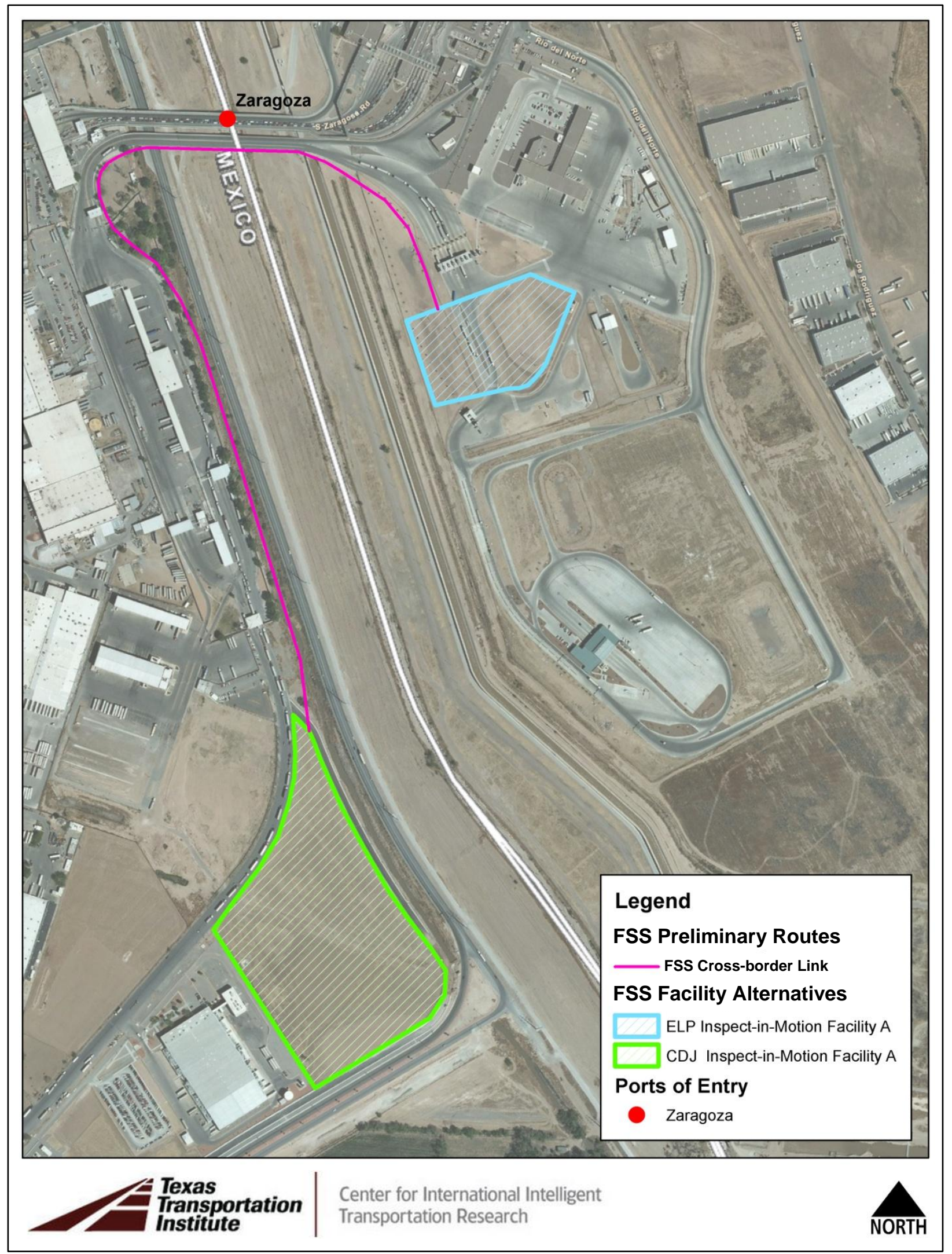

Figure 16. The FSS Cross-border Link connecting Inspect-in-Motion Facilities A-A 


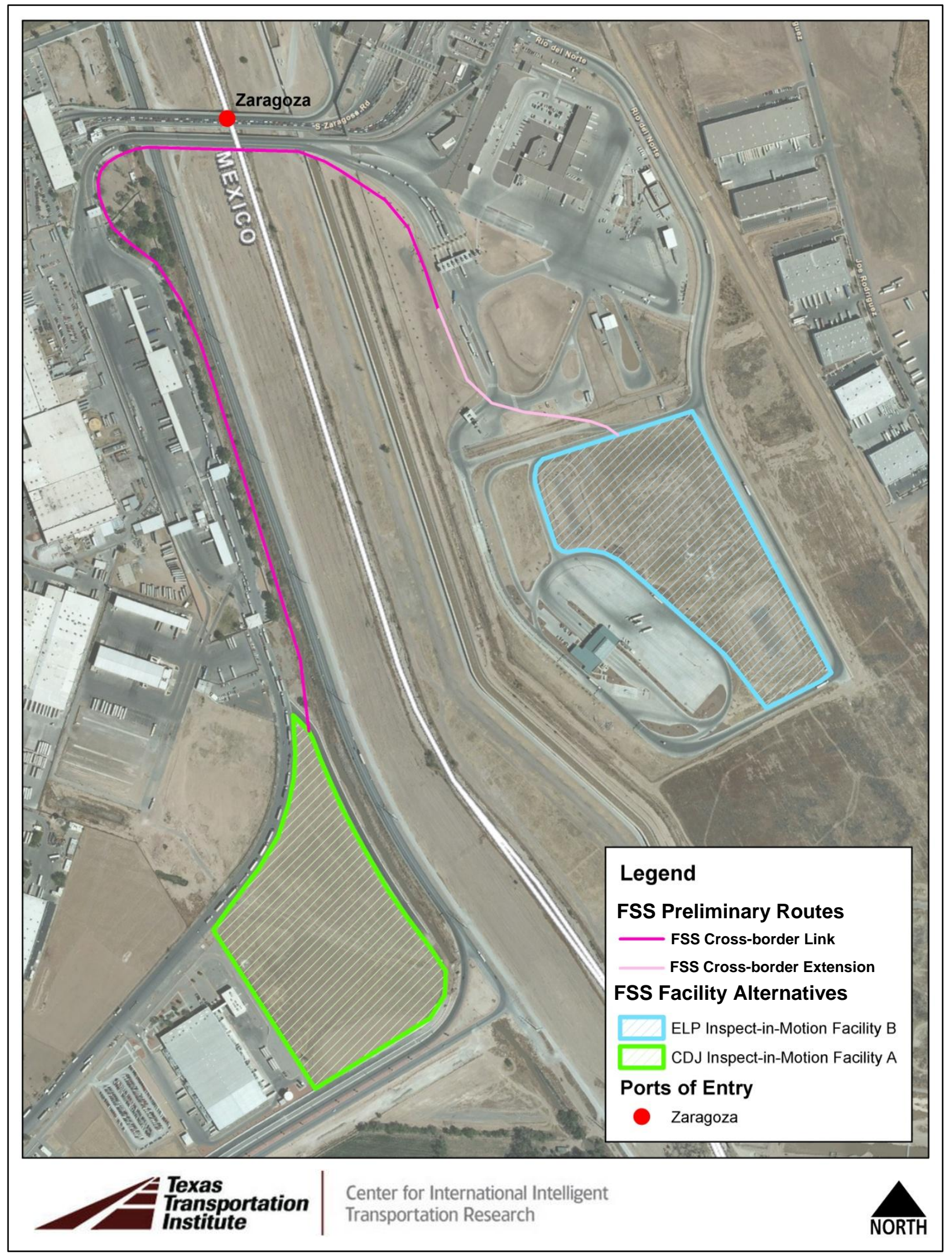

Figure 17. The FSS Cross-border Link connecting the Inspect-in-Motion Facility B-A 


\section{Alternative Terminal Facilities}

For the alternative analysis for FSS terminals in El Paso and Ciudad Juarez, terminal facilities are expected to require a minimum of 20 acres for operations (see Figure 18). To ensure the availability of enough vacant land for current and future use, 30 acre sites are proposed from available vacant land and represented in the maps. This extra acreage assures that the site will have the flexibility to allow for design additions or improvements to the terminal.

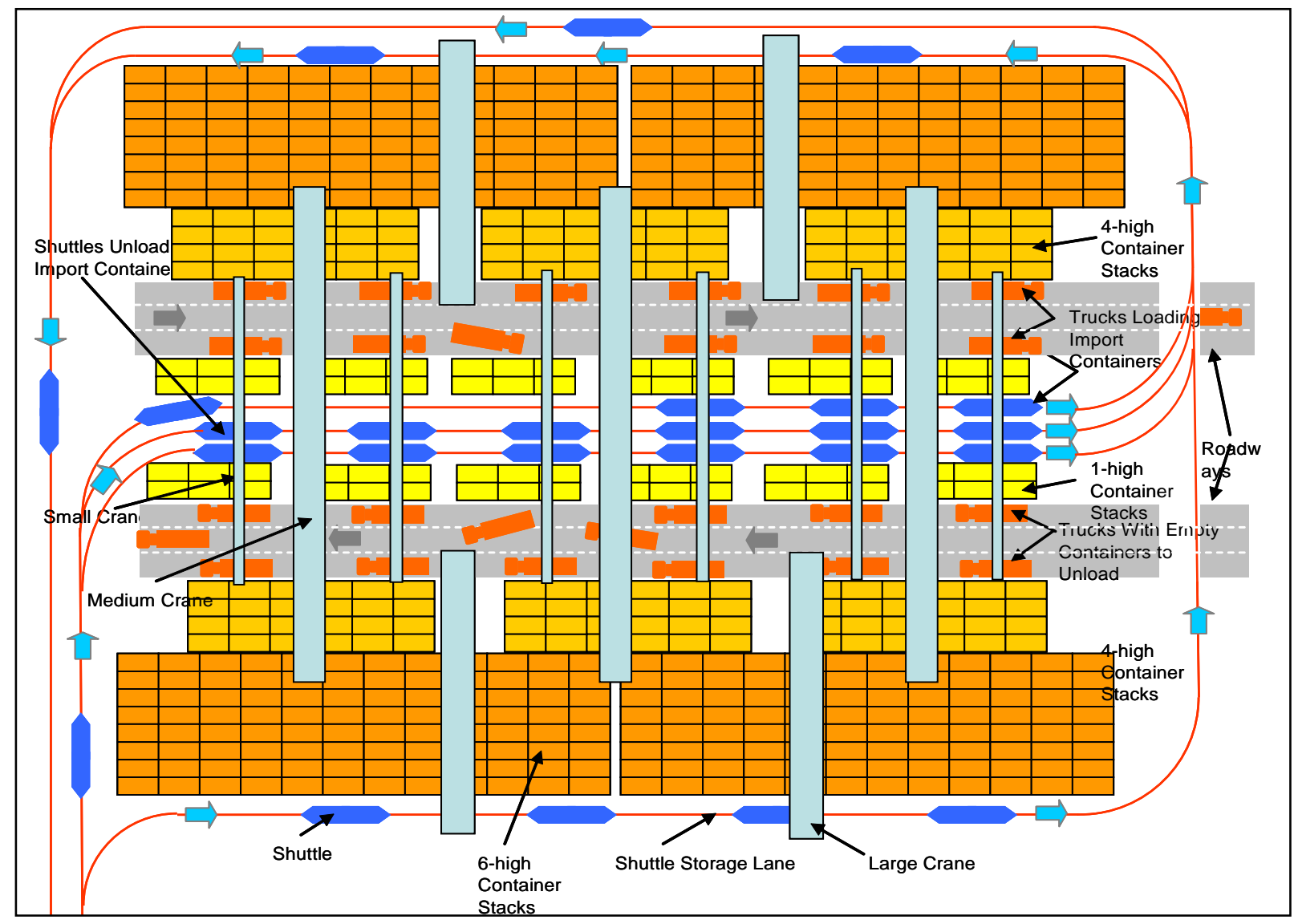

Figure 18. FSS Terminal Facility Drawing

\section{EI Paso System Configuration Alternative 1}

ELP-Terminal-1 is located in the proximities of the Ysleta-Zaragoza POE. It measures approximately 30 acres. It is owned by the El Paso Water Utilities Public Service Board (PSB). The availability of this parcel for industrial uses was confirmed by PSB officials. This parcel is illustrated by the red (cross-hatched) polygon (see Figure 19).

ELP-Route-1 goes from the ELP-Terminal-1 to the proposed inspect-in-motion facility at the Ysleta-Zaragoza POE. It measures 0.72 miles. This route leaves the terminal using ROW over a rural road; follows parallel to the borderline south of the existent inspection facilities; and connects to the proposed ELP-Inspect-in-motion Facility A (see Figure 19). Being that the route passes through mostly undeveloped areas, there are no significant infrastructure conflicts foreseeable on this route. 


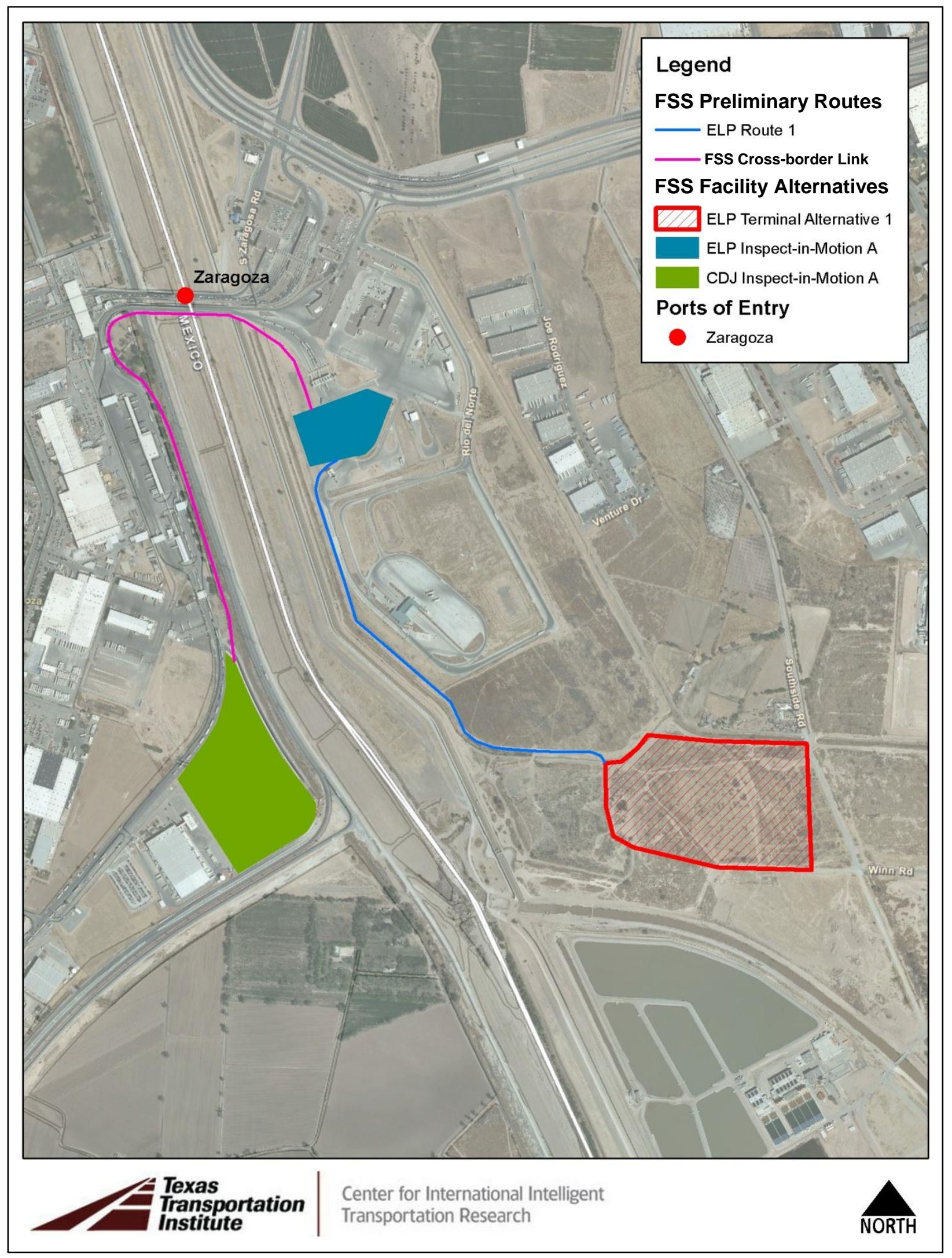

Figure 19. FSS System Configuration Alternative 1 for El Paso 


\section{El Paso System Configuration Alternative 2}

ELP-Terminal-2 is located just less than three miles east and north of the Ysleta-Zaragoza POE. It measures approximately 30 acres. It's owned by Ivey Ben L LTD. The land is currently being used for agricultural purposes. The availability of this parcel for industrial uses is not yet known.

ELP-Route-2 goes from the ELP-Terminal-2 to the Ysleta-Zaragoza POE. It measures 2.93 miles. This route leaves the terminal and would need to pass over N Americas Ave to use ROW in the center median along Americas Ave. The route would then continue along the Americas Ave median for about 2.3 miles. Various minor infrastructure conflicts would need to be addressed along this route, including street lights and overhead highway road signs. At the curve where the avenue turns northward, about 0.2 miles short of the intersection with Zaragosa Rd, the route would cross south over the Cesar E. Chavez Border Hwy and S Americas Ave to run along ROW adjacent to Rio Del Norte Dr. This section runs for about 0.3 miles, where the route would cross above Rio Del Norte Dr and turn west to connect to the proposed ELP-Inspect-inmotion Facility A (see Figure 20). 


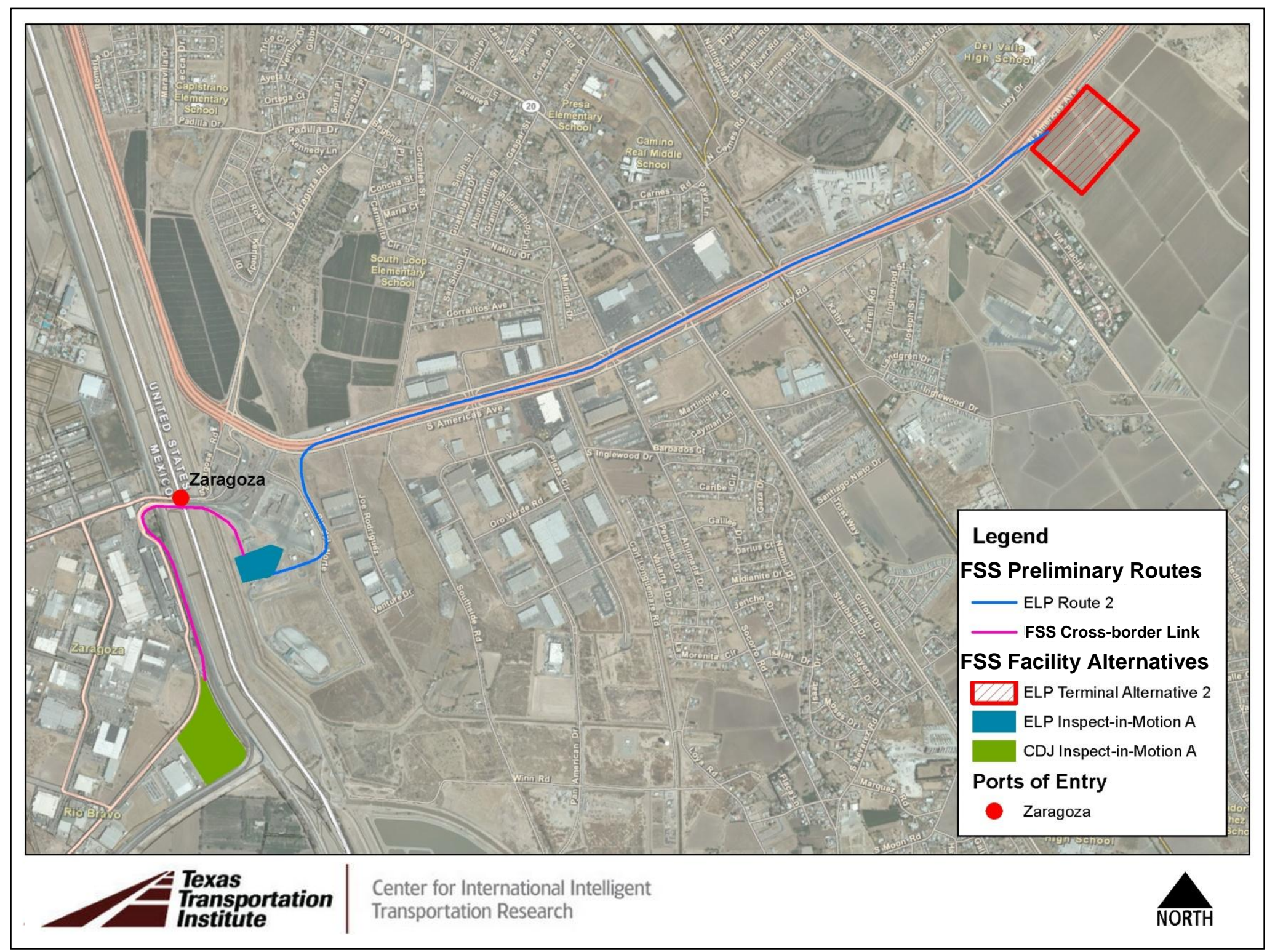

Figure 20. FSS System Configuration Alternative 2 for EI Paso 


\section{El Paso System Configuration Alternative 3}

ELP-Terminal-3 is located adjacent to Interstate 10, about 4.2 miles east and north from the Ysleta-Zaragoza POE. It measures approximately 30 acres. The current owner of the parcel is Tiberias Investments LLC \& 5. The land is currently vacant, raw desert. The availability of this parcel for industrial uses is not yet known

ELP-Route-3 goes from the ELP-Terminal-1 to the Ysleta-Zaragoza POE. It measures 4.60 miles. This route leaves the terminal and would need to immediately pass over Interstate 10 to then head west over parcels of vacant land and agricultural land. At that point, the rest of the route follows in the same line as route 2. It would pass over $\mathrm{N}$ Americas Ave to use ROW in the center median along Americas Ave. The route would then continue along the Americas Ave median for about 2.3 miles. Various minor infrastructure conflicts would need to be addressed along this route, including street lights and overhead highway road signs. At the curve where the avenue turns northward, about 0.2 miles short of the intersection with Zaragosa Rd, the route would cross south over the Cesar E. Chavez Border Hwy and S Americas Ave to run along ROW adjacent to Rio Del Norte Dr. This section runs for about 0.3 miles, where the route would cross above Rio Del Norte Dr and turn west to connect to the proposed ELP-Inspect-in-motion Facility A (see Figure 21). 


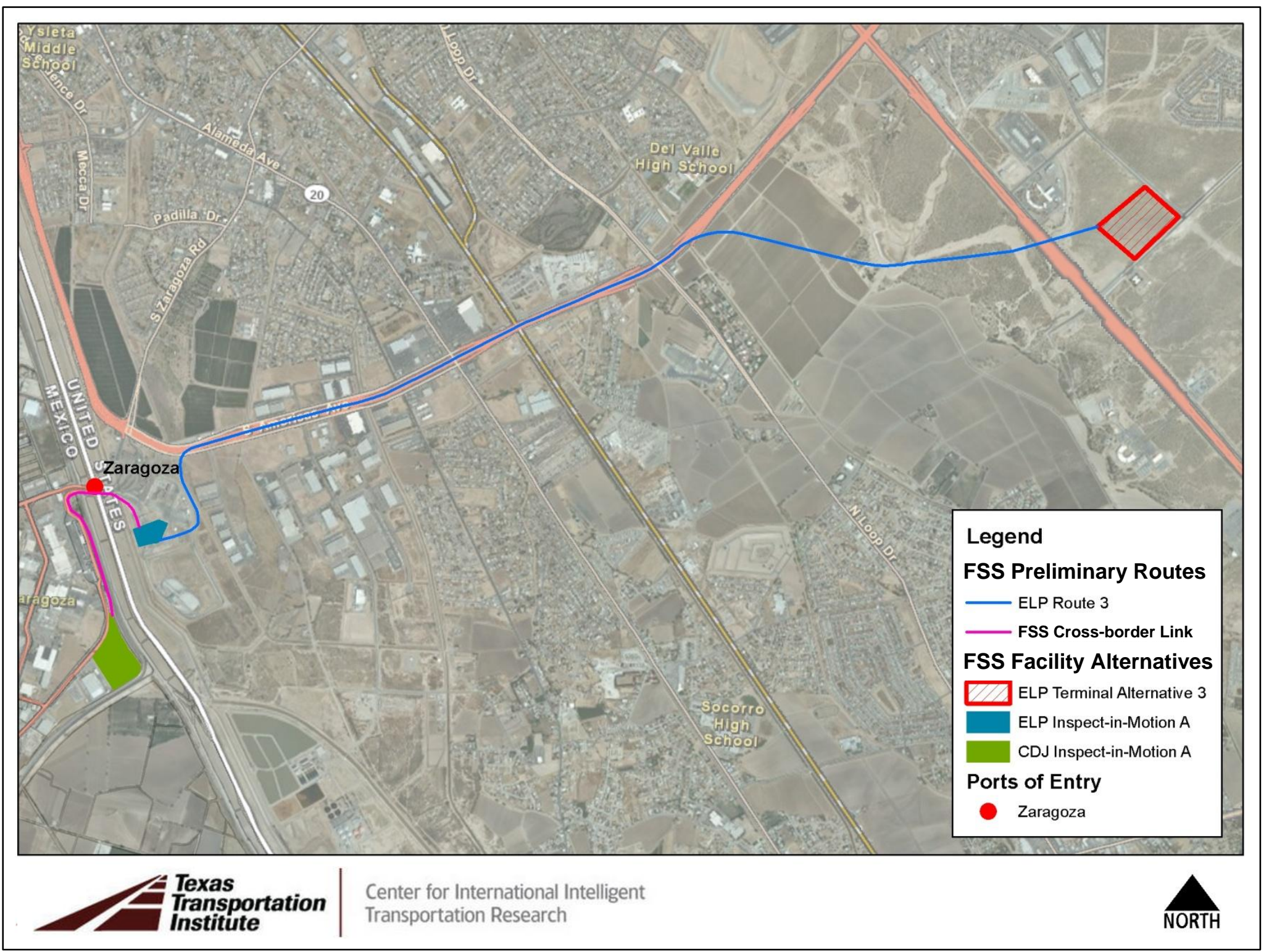

Figure 21. FSS System Configuration Alternative 3 for El Paso 


\section{CDJ Terminal Facility Alternative 1}

CDJ-Terminal-1 is located about 6.7 miles south and west of the Ysleta-Zaragoza POE. It measures approximately 30 acres. The owner is not currently known. The land is currently vacant and raw. The availability of this parcel for industrial uses is not yet known.

CDJ-Route-1 goes from the CDJ-Terminal-1 to the Ysleta-Zaragoza POE. It measures 6.48 miles. This route leaves the terminal and would follow a northeast direction along Calle Independencia for about 1.5 miles, then would continue northeast along Boulevard Independencia (this road is also Mexican Federal Hwy 2 for most of its length) for about 5.1 miles to connect to the proposed CDJ-Inspect-in-motion Facility A (see Figure 22).

Various infrastructure considerations and determinations would need to be made concerning the route. Due to developments on both sides of the route, the ROW along the median appears to be the most feasible placement for the shuttle track. One significant concern is that there are some high voltage wires that travel along the southeastern side of Calle Independencia and later Boulevard Independencia (see Figure 23). These wires continue along the route for about 2.9 miles until the intersection of Boulevard Independencia with Boulevard Santiago Blancas. Upon leaving the terminal, the shuttle would have to cross above or below these wires, which would require some reconfiguration of the wire infrastructure at that location.

Otherwise, along the median for Calle Independencia there are only some simple considerations: streetlights; some traffic signal structures; and some telephone or minor power wire crossings. At the transition where Calle Independencia meets Boulevard Independencia, there are what appears to be some medium size power lines, and the shuttle guideway will need to rise to continue on the raised median of the boulevard. Along the boulevard median, there is the issue of some large street lights that would need to be reconfigured, and some palm plantings that will need to be moved, as well as some highway signs and occasional minor power lines. The intersection with Boulevard Santiago Blancas does pose an interesting scenario, and will require some significant reconfiguration. Boulevard Independencia currently travels below, and at the same time the high voltage lines mentioned earlier cross over the path of the shuttle to the northeast (see Figure 25).

At about 2.8 miles along the route on Boulevard Independencia, there may or may not be a short section of the highway that is not yet constructed. Finally, at about 4.0 miles along the route (shortly after the Mexican Federal Highway 2 splits of to the east and south), there is a short section of about 0.22 miles where the median becomes very small, perhaps 2.5 feet wide. This may need to be addressed, but there is ample space in the ROW on the east or west side to accommodate the shuttle track for this stretch. The track can easily follow the median the rest of the way, finally passing over the southbound lane of Boulevard Independencia to connect to the proposed CDJ-Inspect-in-motion Facility A (see Figure 22). 


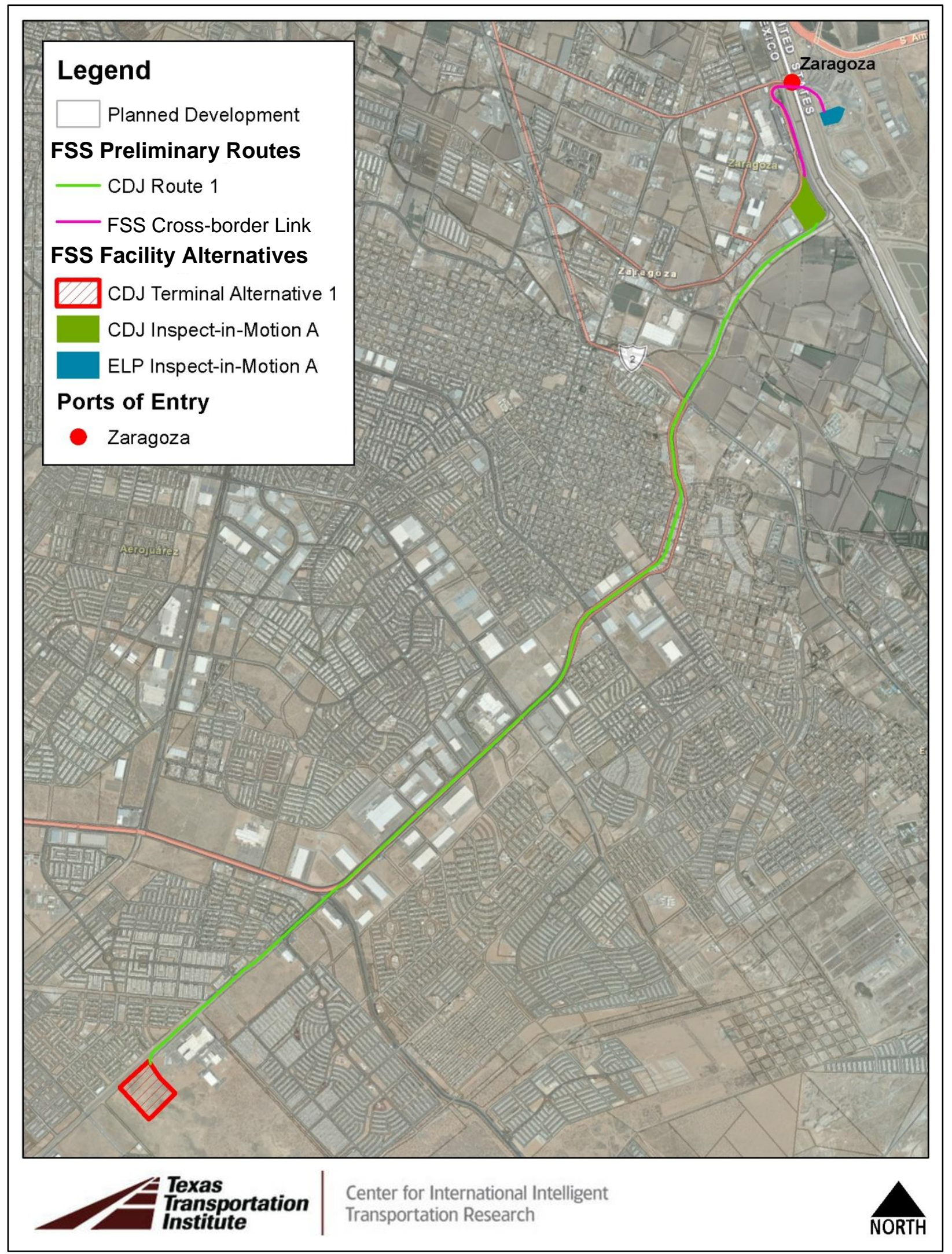

Figure 22. FSS System Configuration Alternative 1 for Ciudad Juarez 


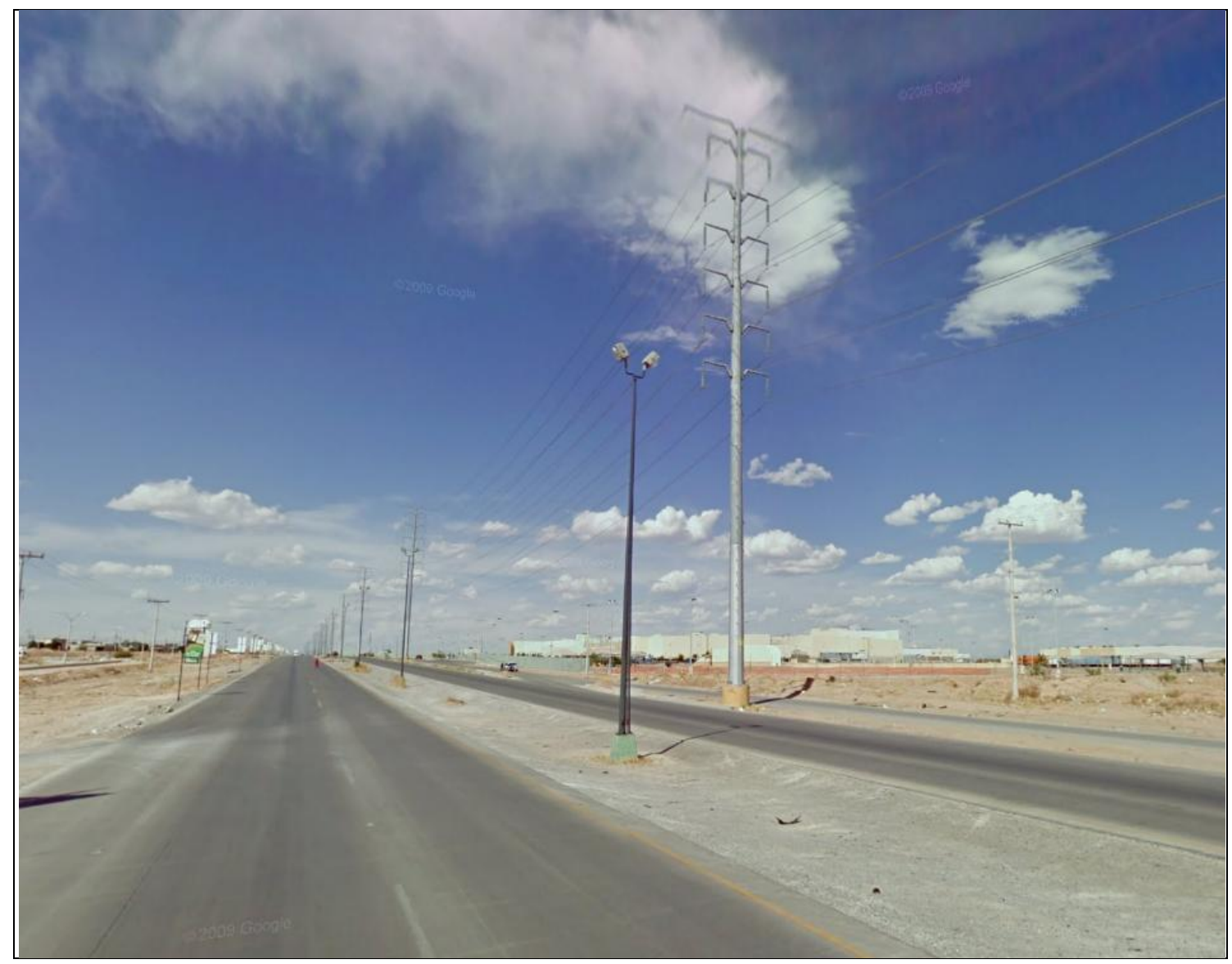

Figure 23. High voltage power lines along CDJ Route 1

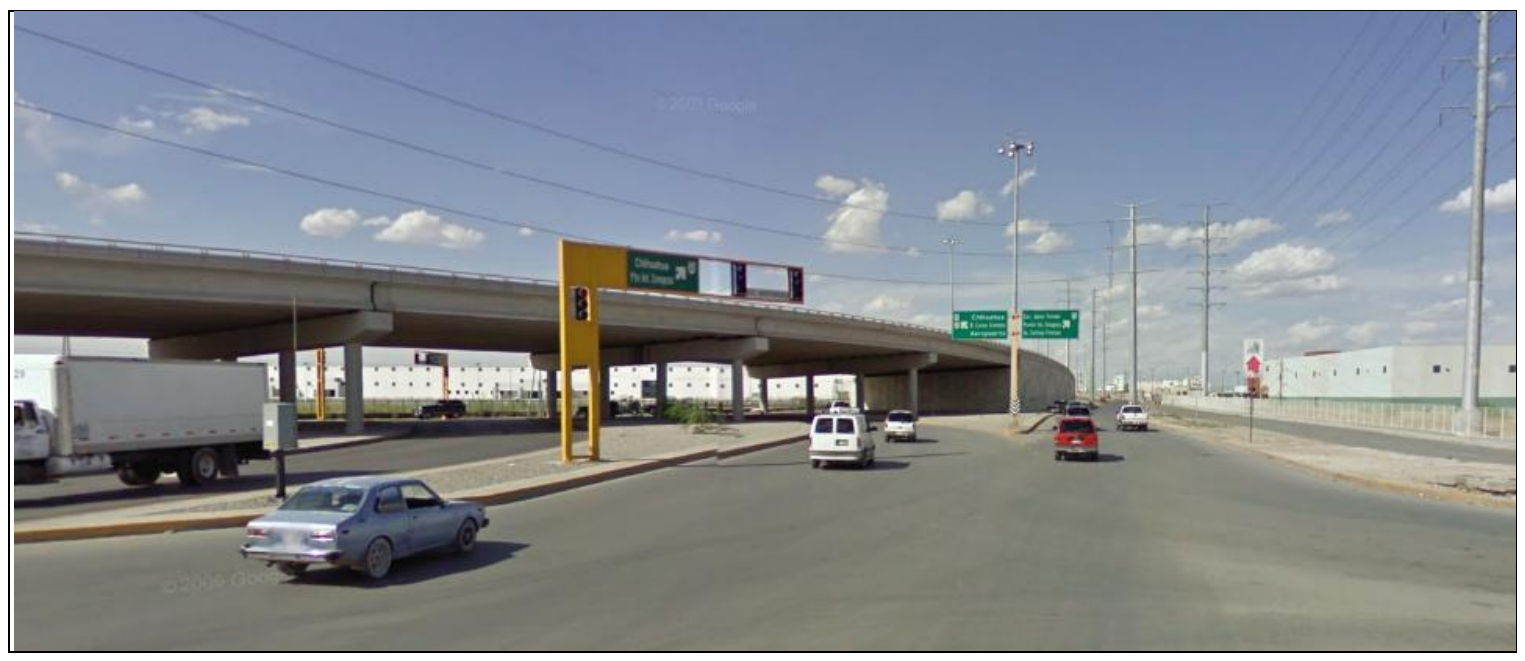

Figure 24. The Transition Scenario at Boulevard Independencia for CDJ Route 1 


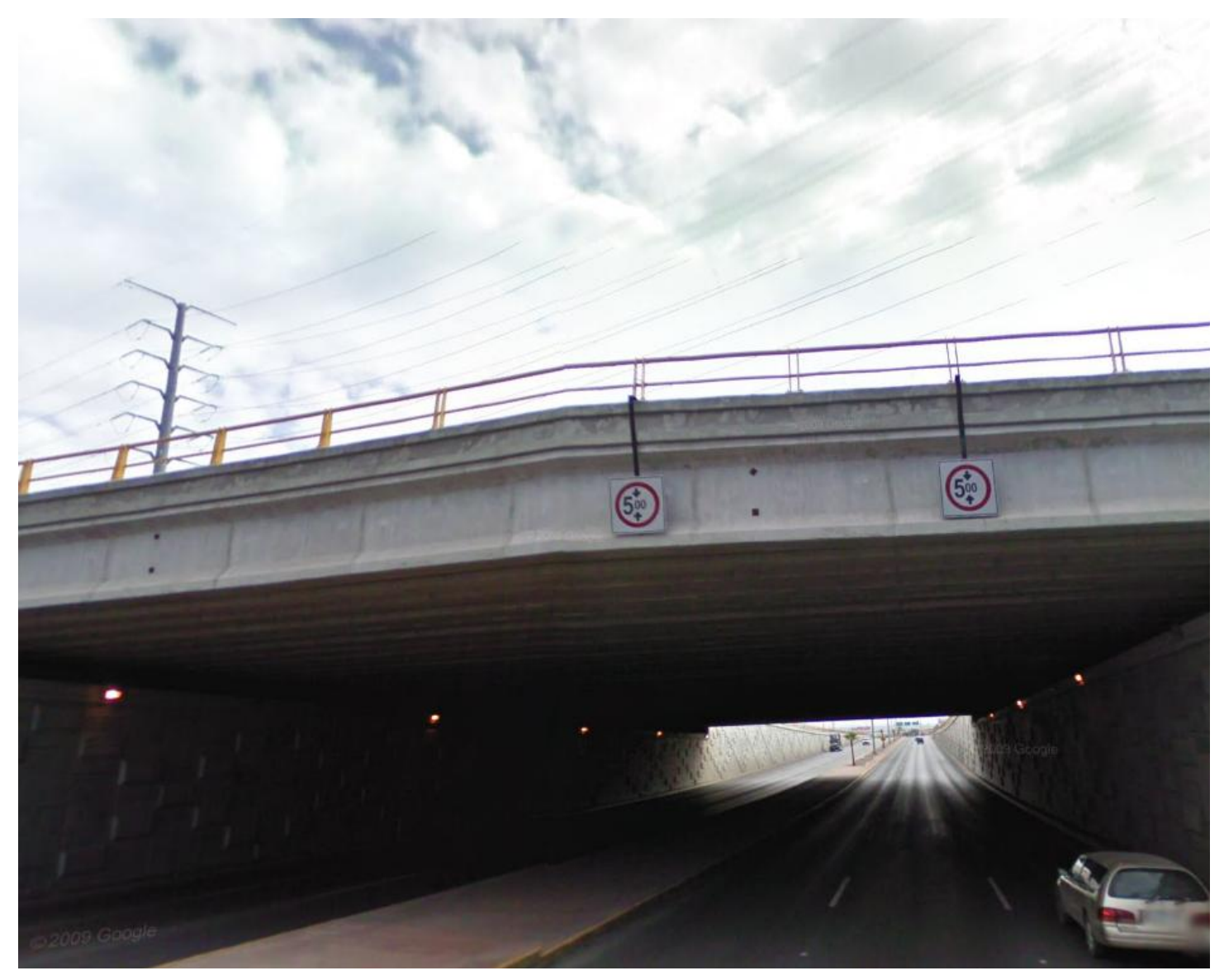

Figure 25. The Intersection with Boulevard Santiago Blancas on CDJ Route 1

\section{CDJ Terminal Facility Alternative 2}

CDJ-Terminal-2 is located in the raw desert in the southeast of Ciudad Juarez, about 6.6 miles due south of the Ysleta-Zaragoza POE. It measures approximately 30 acres. The owner is not currently known. The land is currently vacant and raw. The availability of this parcel for industrial uses is not yet known.

CDJ-Route-2 goes from the CDJ-Terminal-2 to the Ysleta-Zaragoza POE. It measures 7.40 miles. This route leaves the terminal using ROW along an unpaved rural road for about 1.8 miles. No infrastructure conflicts were identified. The route would intersect with the Mexican Federal Highway 2 and turn north and west along that road for 4.5 miles until meeting Blvd Independencia. Initially, for the first 0.6 miles, there is no median in the highway. While there is no median, there is ample room on either side of the highway to accommodate the shuttle track. Thereafter, the track could follow the median, or switch between the median and either side as this portion also has sufficient space along its sides to accommodate the track. Along the entire length of Highway 2 no significant infrastructure conflicts were identified, only minor issues of telephone and power wires. At the intersection with Blvd Independencia the track would rise to intersect the road above and thereafter follow the same path as CDJ Route 1 along the median for 1.2 miles to connect to the proposed CDJ-Inspect-in-motion Facility A (see Figure 26). 


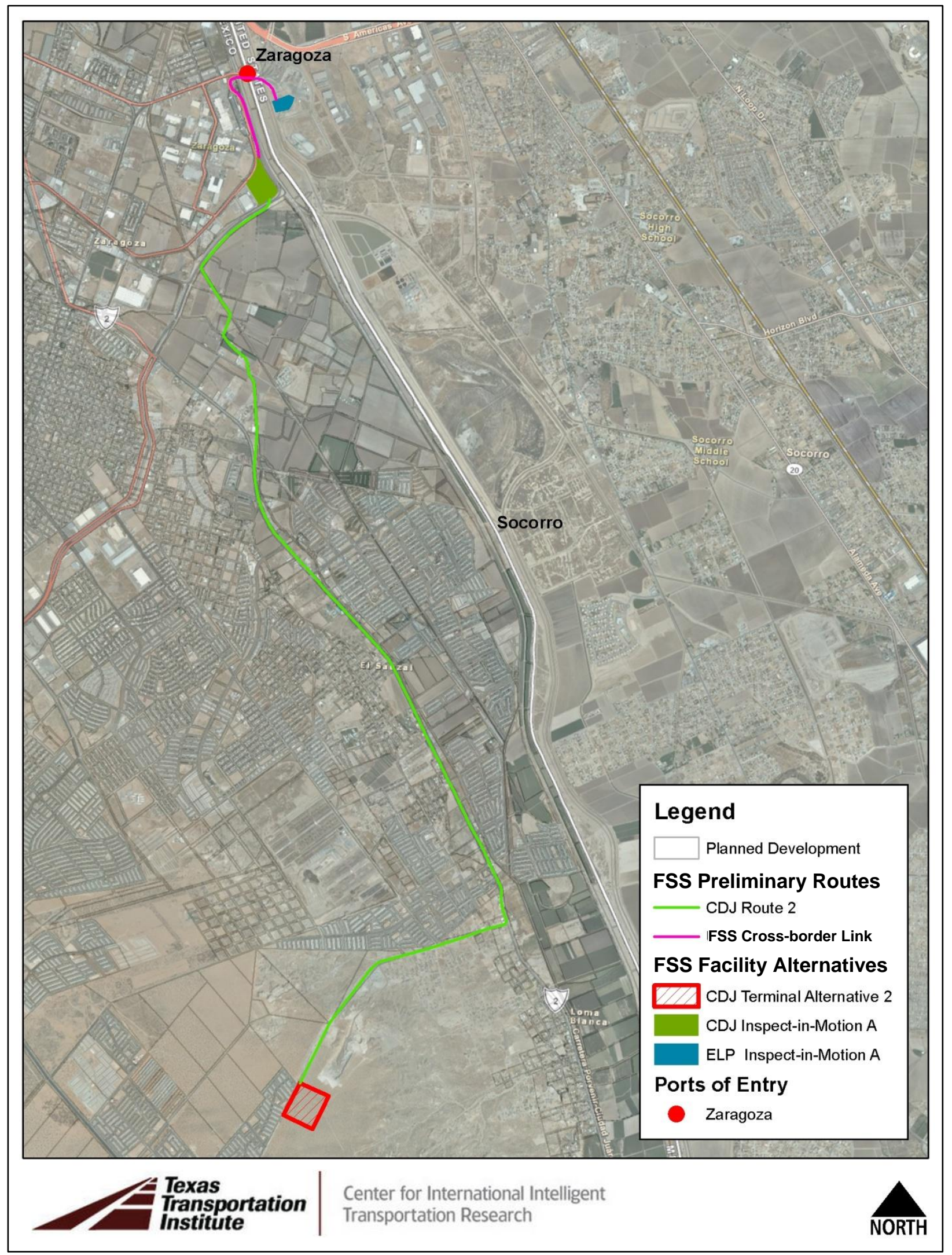

Figure 26. FSS System Configuration Alternative 2 for Ciudad Juarez 


\section{CDJ Terminal Facility Alternative 3}

CDJ-Terminal-3 is located in the open desert south of Ciudad Juarez, about 11.7 miles south and west of the Ysleta-Zaragoza POE. It measures approximately 30 acres. The owner is not currently known. The land is currently vacant and raw. The availability of this parcel for industrial uses is not yet known.

CDJ-Route-3 goes from the CDJ-Terminal-3 to the Ysleta-Zaragoza POE. It measures 15.34 miles. This route leaves the terminal and would follow a northeast direction first through raw open desert for about 3.5 miles. Along this stretch there are no infrastructure conflicts. The route would intersect with Calle Independencia and turn northwest along that road. As the median here is being occupied by high voltage power lines, the track should run along the ROW on the southwestern side. This stretch measures about 1.3 miles. Along this stretch the power lines would need to be crossed once. When Calle Independencia turns to the northeast, the route would also turn, again needing to cross the path of the high voltage lines. Then, the track would run along the median to meet up with and thereafter follow the same path as CDJ Route 1. Thus the track would continue northeast, then travel along Boulevard Independencia (this road is also Mexican Federal Hwy 2 for most of its length) for about 5.1 miles to connect to the proposed CDJ-Inspect-in-motion Facility A (see Figure 27).

Various other infrastructure considerations and determinations would need to be made concerning the route. Any considerations not discussed above would be identical to the issues discussed in CDJ route 1 along the 6.48 miles of path that they share (see CDJ-Route-2 and Figure 26). 


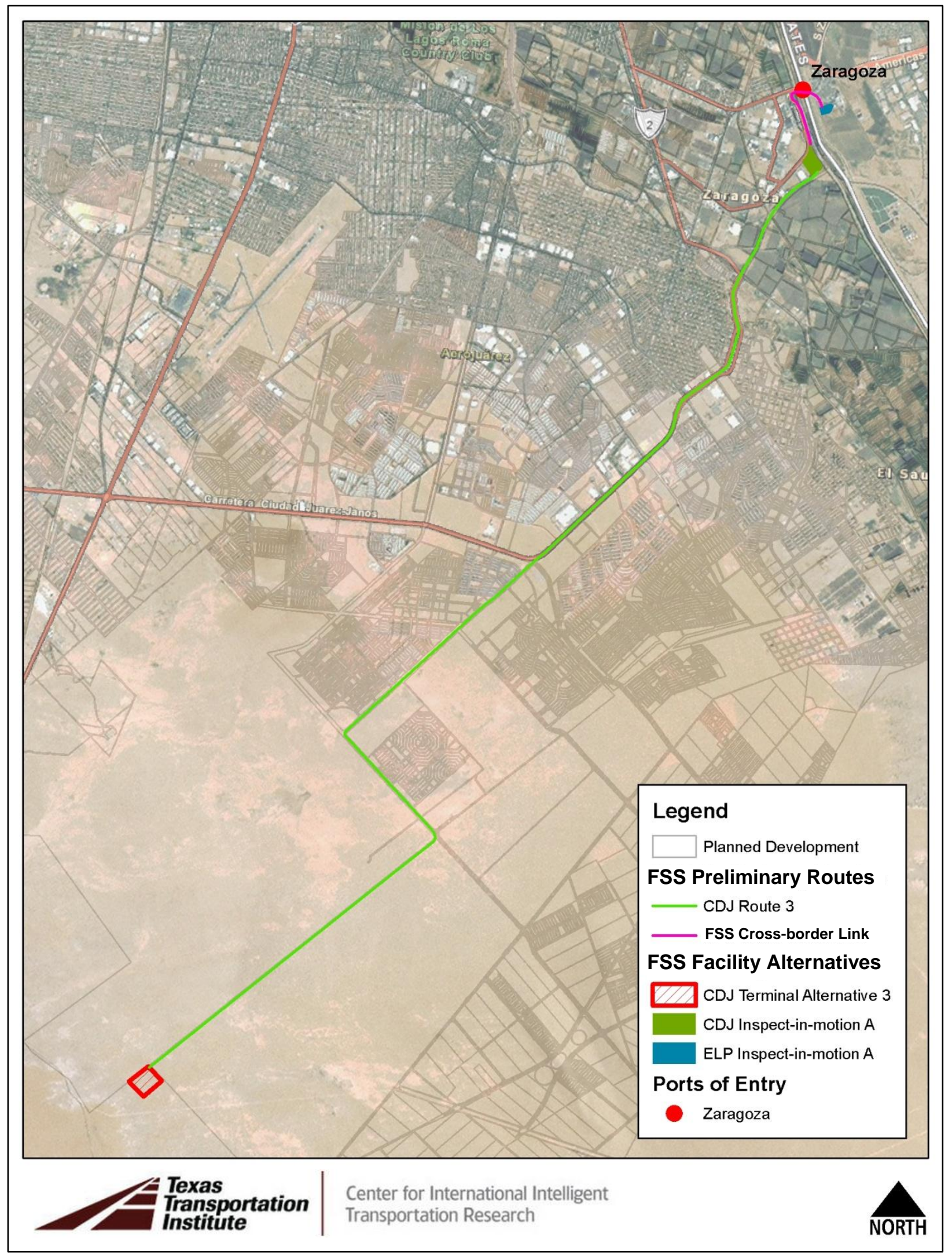

Figure 27. FSS System Configuration Alternative 3 for Ciudad Juarez 


\subsection{CHAPTER SUMMARY AND RECOMMENDATIONS}

This chapter identified target locations for terminals, inspect-in-motion facilities, and a viable port of entry (POE) to explore alternatives for the FSS system configuration, and to assess the feasibility of binational operations in the El Paso - Ciudad Juarez region.

After assessing all POEs in the El Paso - Ciudad Juarez region, the Ysleta-Zaragoza POE represents the most viable alternative for a FSS border-crossing. The existing infrastructure at this POE presents suitable characteristics for implementation since no current obstacles were identified. Meetings with government officials, planning agencies, and maquiladoras revealed a clear preference to use this POE. In the long run, as new industrial developments take place near Fabens, the Tornillo-Guadalupe POE at Fabens could represent an alternative for a second route to cross the border.

The objectives of a binational implementation of the FSS project are consistent with the goals of the TxDOT, the City of El Paso, and the Camino Real Regional Mobility Authority (CRRMA), as part of their long range strategic plans in the metropolitan area of El Paso. The long-range plans for Ciudad Juarez might favor industrial developments towards the southern part of the city. Additionally, there is a clear preference to divert trucks to the outermost areas of the city, as opposed to areas near BOTA.

Alternative 1, composed by ELP Route 1, CDJ Route 1, and the FSS Cross-border Link, measures 8.116 miles. This seems the most viable alternative, as revealed by our analysis of the location of most of the potential customers for the FSS; their existing practices and preferences; the existing infrastructure at the Ysleta-Zaragoza POE; and the regional growth and development plans of both cities.

The strategic location of ELP Terminal 1 and CDJ Terminal 1 represents an opportunity to capture markets in CDJ-Cluster No3 and ELP Cluster No1; moreover, CDJ Cluster No 2 and ELP Cluster No 2 are also very close and with excellent connectivity to these two terminals respectively. Alternative 1 also has room for future capacity expansions in all of its components (i.e. terminals and inspect-in-motion facilities on U.S. and Mexican sides). This Alternative also allows for the establishment of satellite terminals or FSS border crossings through Santa Teresa NM and the Tornillo/Guadalupe POE at Fabens for the long run.

Once the FSS is incorporated as a project in the regional development plans of both cities, careful attention should be paid to promote only industrial developments in areas adjacent to the terminals, and to divert truck traffic towards the terminals. 


\section{CHAPTER 5:}

\section{ANALYSIS OF REGULATORY AND INSTITUTIONAL FRAMEWORKS, AND ASSESSMENT OF MANAGEMENT MODELS}

\subsection{OVERVIEW}

The objective of this chapter is to provide an overview of the regulatory and institutional framework that would govern the FSS, and present a potential management model for the FSS system that would operate within these frameworks. The chapter starts with a review of key U.S. and Mexican laws and regulations that would govern and influence the binational planning, implementation and operations of the FSS system. This review is followed by an analysis of the current institutional framework for commercial border crossing operations that assesses the public and private sector stakeholders involved based on their capacity to influence the implementation or change the course of the project. The chapter concludes with a discussion of the potential binational management model for the FSS system operation and an outline of the entities that would have to be created in Mexico and the U.S. to implement and operate the project. The chapter is organized in three sections:

5.2 Regulatory Framework for Binational Implementation. This section reviews key U.S. and Mexican laws and regulations that define: (i) the procedures required for the planning and implementation of new border crossings or new capacity at existing border crossings (including the U.S. presidential permit application and equivalent Mexican regulations); (ii) the roles and responsibilities of government agencies in these procedures; and (iii) the possible limitations to private sector participation in border-crossing infrastructure investment.

5.3 Commercial Border Crossing--Institutions. This section identifies the institutions, agencies, or private groups currently involved in the commercial border crossing process. This section analyzes the project's public and private stakeholders and uses a stakeholder map to categorize stakeholders according to their capacity to influence the implementation of the project. The analysis identifies those stakeholders that will require greater attention for the successful implementation of the system.

5.4 Binational Institutional Model for Operations. This section presents a conceptual institutional model for the operation of the FSS system in a binational setting based on the findings of the regulatory and institutional analysis. More specifically, the model outlines the possible role of U.S. and Mexican government agencies that would be involved on the day-to-day cross border operation of the system (e.g. the role of customs agencies in the inspect-in-motion facilities).

5.5 Binational Business Management Structure. This section presents a binational business management structure for implementation and operations. The structure defines the roles and responsibilities for Freight Shuttle International and the FSS Licensees or Investors in the U.S. and in Mexico. 
5.7 Chapter Summary and Recommendations. This section summarizes findings and conclusions, and provides recommendations for project implementation.

\subsection{REGULATORY FRAMEWORK FOR BINATIONAL IMPLEMENTATION}

The binational nature of the FSS system requires the project to comply with both, the U.S. and Mexican legal and regulatory frameworks. The fact that these two distinct frameworks also encompass all levels of government (i.e. federal, state, and local levels) in both countries adds complexity to the planning and implementation of the project and understanding them is crucial to its ultimate success. This section seeks to document key laws and regulations in both countries that are relevant to the planning and implementation of the FSS system, to obtain an understanding of the jurisdictional roles and responsibilities that different government agencies would have in this process, and to identify any major legal impediments to the participation of the private sector in a binational FSS system.

\section{U.S. Federal Legal Framework}

This section uses as primary reference the following two sources:

- Applying for Presidential Permits for Border Crossing Facilities (Mexico). Bureau of Western Hemisphere Affairs Fact Sheet. Department of State. January 2009, consulted on October 2010: http://www.state.gov/p/wha/rls/fs/2009/114980.htm\#

- Interpretative Guidance on Executive Order 11423. Department of State. February 2007, consulted on October 2010: http://www.state.gov/p/wha/rls/94946.htm

Under Executive Order 11423, as amended, the President has delegated to the U.S. Department of State (DOS) the authority to receive applications for, and to approve and issue, Presidential permits for the construction, connection, operation, or maintenance of certain facilities at the U.S.-Mexico border. The DOS determined this authority applicable to all new border crossings and to all substantial modifications of existing border crossings. Substantial modifications are defined as:

- an expansion beyond the existing footprint of a port-of-entry (POE) inspection facility including its grounds, approaches, and appurtenances, at an existing border crossing in such a way that the modification effectively constitutes a new piercing of the border;

- a change in ownership of a border crossing that is not encompassed within or provided for under an applicable Presidential permit;

- a permanent change in authorized conveyance (i.e. commercial traffic, passenger vehicles, pedestrians, etc.) not consistent with:

0 what is stated in an applicable Presidential permit, or

- current operations if a Presidential permit or other operating authority has not been established for the facility; or

- any other modification that would render inaccurate the definition of covered U.S. facilities set forth in an applicable Presidential permit. 
The DOS determined this authority applicable to the following categories of border crossings: bridges; tunnels; roadway crossings; rail crossings; bicycle crossings; pedestrian crossings; cross-border conveyors; and Livestock crossings. The DOS determines whether a proposed border-crossing project is in the U.S. national interest. In order to make this determination, the DOS must work with federal agencies such as:

- Department of Transportation (DOT),

- General Services Administration (GSA),

- Department of Homeland Security's (DHS) Bureau of Customs and Border Protection (CBP),

- Environmental Protection Agency (EPA),

- Coast Guard (if the project is an international bridge), and

- U.S. Section of the International Boundary and Water Commission (IWBC).

In addition the DOS is required to coordinate closely with state and local agencies (i.e. TxDOT and the City of El Paso) and to invite public comment in arriving at its determination. The DOS recognizes that it is generally in the national interest to facilitate the efficient movement of legitimate goods across U.S. borders-within the context of appropriate border security, safety, health, and environmental requirements. The guidance also states that DOS will cooperate with other agencies to fulfill any applicable requirements under NEPA. Additionally, the DOS recognizes that implementing regulations issued by the Council on Environmental Quality may have separate and distinct obligations under NEPA for other involved federal agencies. Finally, the guidance states that depending on the project, the DOS may serve as the lead agency, a co-lead agency, or a cooperating agency.

Table 17 below reviews the Presidential Permit requirements as defined in the DOS guidance and in the context of the FSS. The table also identifies how each of these requirements relates to the FSS system, and when relevant identifies possible action items for the project.

Table 17. Summary of the Presidential Permit Requirements

\begin{tabular}{|l|l|l|}
\hline \multicolumn{1}{|c|}{ Concept } & \multicolumn{1}{|c|}{ Definition } & \multicolumn{1}{|c|}{$\begin{array}{c}\text { Relationship or Action Item with } \\
\text { FSS }\end{array}$} \\
\hline $\begin{array}{l}\text { Project } \\
\text { Sponsor }\end{array}$ & $\begin{array}{l}\text { A Presidential permit will only be issued to a project } \\
\text { sponsor-an entity that has ownership, jurisdiction, custody, } \\
\text { or control of the U.S. portion of a border crossing - this may } \\
\text { be a federal, state, or local government entity, or a private } \\
\text { individual or group. }\end{array}$ & $\begin{array}{l}\text { FSI will need to identify and } \\
\text { designate who the project sponsor } \\
\text { will be. The FSS Terminal Location } \\
\text { Alternatives analysis suggests that } \\
\text { the Zaragoza-Ysleta POE, owned by } \\
\text { the City of El Paso, is the most } \\
\text { technically feasible alternative. } \\
\text { Therefore, the City of El Paso could } \\
\text { be designated as the project sponsor } \\
\text { of a border crossing facility for the } \\
\text { U.S. portion of the FSS. }\end{array}$ \\
\hline $\begin{array}{l}\text { Department of } \\
\text { State } \\
\text { Notification. }\end{array}$ & $\begin{array}{l}\text { As described in their Interpretative Guidance of Executive } \\
\text { Order 11423 (included in Appendix C) the DOS has } \\
\text { identified three categories of projects for purposes of } \\
\text { notification to the DOS: (i) Red, (ii) Yellow, and (iii) Green. } \\
\text { These three categories are based on the magnitude and } \\
\text { complexity of the proposed changes at the border. }\end{array}$ & $\begin{array}{l}\text { Given the provided definition in the } \\
\text { DOS, the implementation of a } \\
\text { binational FSS system, falls under } \\
\text { the DOS Red category (defined in } \\
\text { the next row), and the FSS project } \\
\text { sponsor must inform DOS at the } \\
\text { earliest opportunity. }\end{array}$ \\
\hline
\end{tabular}




\begin{tabular}{|c|c|c|}
\hline Concept & Definition & $\begin{array}{c}\text { Relationship or Action Item with } \\
\text { FSS }\end{array}$ \\
\hline $\begin{array}{l}\text { The Red } \\
\text { Category }\end{array}$ & $\begin{array}{l}\text { Covers all new border crossings and those proposed changes } \\
\text { that make a substantial modification to an existing border } \\
\text { crossing. An expansion beyond the existing footprint of a } \\
\text { POE inspection facility in such a way that the modification } \\
\text { effectively constitutes a new piercing of the border. The } \\
\text { addition of lanes to an existing border crossing or the } \\
\text { replacement of existing lanes with new lanes is not a } \\
\text { substantial modification and falls under the yellow category. } \\
\text { A change in ownership of a border crossing or a permanent } \\
\text { change in authorized conveyance if not consistent with the } \\
\text { previously-issued Presidential permit, will require an } \\
\text { amendment to the Presidential permit. When a Presidential } \\
\text { permit or operating authority has not been established for a } \\
\text { facility, a Presidential permit will be required if a permanent } \\
\text { change in authorized conveyance is being sought that is at } \\
\text { variance with the current operations. A substantial } \\
\text { modification also could be any modification that renders } \\
\text { inaccurate the definition of covered U.S. facilities set forth in } \\
\text { an applicable Presidential permit. }\end{array}$ & $\begin{array}{l}\text { In all red category cases, a } \\
\text { Presidential permit application must } \\
\text { be submitted and approved before } \\
\text { construction activities begin. This } \\
\text { does not prevent the sponsor from } \\
\text { performing or contracting for other } \\
\text { project due diligence activities as } \\
\text { warranted and at its own risk (i.e. } \\
\text { preparation of environmental } \\
\text { documentation under NEPA, project } \\
\text { design, other permit applications, } \\
\text { etc.) while DOS decides whether to } \\
\text { issue the Presidential permit. }\end{array}$ \\
\hline $\begin{array}{l}\text { The } \\
\text { Application }\end{array}$ & $\begin{array}{l}\text { Presidential permit applications should include the following } \\
\text { (see Appendix C for a complete description of each item): } \\
\text { - Project sponsor information (i.e. municipality, other public } \\
\text { body, partnership, or corporation, etc.) with the legal } \\
\text { authority to make final decisions; furthermore, it should } \\
\text { specify any intention to sell or assign to other entity } \\
\text { facility. } \\
\text { - Detailed description of the proposed facility and of how it } \\
\text { will serve the U.S. national interests. } \\
\text { - Map of similar facilities in the area. } \\
\text { - International current and projected traffic information. } \\
\text { - Construction and financial plans. } \\
\text { - Description of steps taken to secure Mexican Government } \\
\text { approval (Mexican authorities encourage the simultaneous } \\
\text { submission of applications). } \\
\text { - Other U.S. federal, state, and local approvals required for } \\
\text { the proposed facility. } \\
\text { - A list of properties in the project area eligible for inclusion } \\
\text { in the National Register of Historic Properties. } \\
\text { - Environmental justice information or description of } \\
\text { minorities and low-income populations likely to be } \\
\text { affected by construction of the proposed facility. } \\
\text { - Environmental review of foreseeable impacts of the } \\
\text { proposed facility—pursuant to NEPA. }\end{array}$ & $\begin{array}{l}\text { Further preparation of the FSS } \\
\text { project will require legal, } \\
\text { engineering, and other consulting } \\
\text { services to prepare the } \\
\text { documentation required to } \\
\text { consolidate the presidential permit } \\
\text { application. }\end{array}$ \\
\hline
\end{tabular}

In summary, the FSS project sponsor must inform DOS at the earliest opportunity of any change (in policy or otherwise) at the border that could reasonably be expected to affect the U.S. relations with Mexico. The project sponsor should notify DOS promptly of all such planned changes, so that DOS will be in a position to facilitate expeditious resolution of any foreign policy issues that may arise in connection with proposed changes. Once the application is complete, the DOS will instruct the applicant to provide copies-including all environmental and 
other documentation - to relevant federal and state agencies for their comment. The DOS will also publish a notice in the Federal Register inviting public comment on the application. Finally, the Executive Order 11423 specifies certain federal officials with whom the DOS must consult when reviewing a permit application.

\section{State of Texas Legal Framework}

The Texas Transportation Code determines the process by which an international bridge may be constructed in Texas. A political subdivision or private entity that desires to construct or finance the construction of a bridge over the Rio Grande must obtain approval from the Texas Transportation Commission (TTC) for the construction of the bridge before requesting approval from the federal government. To obtain approval, the political subdivision or private entity must submit an application and comply with all requirements and conditions in the Title 43 from the Texas Administrative Code (TAC), Chapter 15, Subchapter G and Section 201.612 and under 33 USC $§ 535$.

To secure approval of a project, an applicant must file an application and 20 copies with TxDOT Deputy Executive Director, or his or her designee, who shall serve as department liaison for the project. The application shall be in a prescribed form and must contain a description of the applicant, including its form of organization under the laws of the state, and a history of the applicant's operations and business. It must also include a definition of major financial, operating, and business policies of the applicant that will affect operations for the conduct of business, including key operating conditions and compliance with existing federal, state, and local laws and regulations. The application will also contain a preliminary study of the project in accordance with the guidelines in 43 TAC $\$ 15.73$. Finally, the application will contain any written commitments from the relevant Mexican Government jurisdictions to provide adequate roadway connections to the bridge and similar commitments from state and municipal transportation agencies for any state highway or local street infrastructure necessary to make the bridge fully operational.

As in the case of the Presidential permit, the potential location of the FSS system crossing through the Zaragoza-Ysleta POE indicates that the City of El Paso would be the lead agency applying for TTC approval for the FSS project.

\section{Mexican Federal Legal Framework}

The process for obtaining approval in Mexico for the construction of new border crossings or expansion/modification of existing ones is different from that in the U.S. The official Mexican Government guidance on rules and regulations for seeking such approvals available on-line is very limited. Therefore, this section uses as primary sources the following:

- The report "Final Report regarding Status, in Mexico, of Brownsville Navigation \& Canal District's Proposed Port Bridge Project" commissioned by the Brownsville Navigation \& Canal District in 2004 (14);

- The U.S./Mexico Joint Working Committee on Transportation Planning's website (http://www.borderplanning.fhwa.dot.gov/); and 
- The document "Proceso para Evaluación de Propuestas de Nuevos Cruces y Puentes Fronterizos de México" (Process for the Evaluation of Proposals for New Border Crossings and Bridges), published by Mexico's federal Secretaria de Comunicaciones y Transportes (Secretariat of Communications and Transportation, or SCT) and included in Annex X (in Spanish) (15).

In Mexico, the approval process for all international border crossing projects is coordinated by an inter-agency body called the "Comision Intersecretarial sobre Cruces y Servicios Fronterizos" (Intersecretarial Group for Bridges and Border Crossings, or CICSF). The CICSF is chaired by the Secretaria de Relaciones Exteriores (Secretariat of Foreign Relations, or SRE) and is responsible for coordinating the federal, state and local with jurisdiction over the negotiation, construction, operation and maintenance of border crossings and the services provided by these facilities. The CICSF also evaluates and approves proposed new border crossings and works to implement border crossing projects once they are approved. The CICSF meets on an as-needed basis as many times per year as required to address specific issues. Box 1 lists the Mexican federal agencies that participate in the CICSF. The CICSF has published a guide for the submission and evaluation of border crossing proposals, the Guía para la Presentación y Evaluación de Propuestas sobre Puertos Fronterizos (Guide for the Presentation and Evaluation of Border Port Proposals). The guide is intended to assist project sponsors meet the requirements for approval of project proposals. The research team was unable to obtain a copy of the guide, but according to Torteya \& Torteya, it defines the following seven (7) steps in the process to seek approval for the construction of a new border crossing project: (i) submission of application; (ii) project analysis by committee; (iii) bonds/guarantee requirements; (iv) binational consultation; (v) review of preliminary version (feasibility study) of proposed border port project; (vi) review of executive project (detailed design); and (vii) review of construction plans. Upon completion of the interagency review process and obtaining preliminary approval from the CICSF, the next step is to request the SCT to commence the procurement process for the concession (generally of the Build-Operate-Transfer, or BOT type). The procurement process is followed by the final approval, concession award and construction of the proposed international border crossing.

The content of the technical dossier of the approval application package includes:

- Site Justification. This set of documents includes: a) environmental impact analysis; (b) analysis of land use and integration into local, state and federal development plans; (c) compliance with international boundaries and water agreements; (d) topographic surveys and integration with roadway network; and (e) concept of operations;

- Conceptual Design (Preliminary Design). This set of documents includes: (a) feasibility study and justification; (b) schematic design; (c) roadway network connections.

- Foreign Conceptual Design (Preliminary Design) and Agreement. This set of documents refers to the Preliminary Design of the American portion of the project, and a letter of commitment from the American and Mexican sponsors to coordinate and carry out the application process on both sides of the border. 
- Financing Scheme. This set of documents describes the financial feasibility of the project, including the proposed capital structure, funding sources, and financing plans for the design, construction, and operation of the project.

- Social Justification of the Project in Mexico and Abroad. This set of documents includes: (a) the socio-economic impact analysis; (b) the demand analysis and forecasts; and (c) cost-benefit analysis.

The members of the CICSF meet with their U.S. counterparts at the Binational Bridges and Border Crossings Group (BBBXG), a group co-hosted by SRE and the DOS twice per year. The BBBXG meetings traditionally consist of two sessions, one open to the general public, and a second one for federal and state agencies only. The BBBXG serves as a mechanism for bilateral coordination in the planning, construction, maintenance and development of border crossings.

\section{Box 1: Mexico's Intersecretarial Group for Bridges and Border Crossings (CICSF)}

The CICSF includes the following government agencies:

- Secretaria de Relaciones Exteriores (Secretariat of Foreign Relations, or SRE)

- Comisión Internacional de Límites y Aguas, Sección Mexicana (International Boundries and Water Commission, Mexican Section, or CILA);

- Secretaría de la Defensa Nacional or (Secretariat of Defense, or SEDENA);

- Secretaría de Gobernación (Secretariat of the Interior, or SEGOB);

- Secretaría de Seguridad Pública (Department of Public Safety, or SSP);

- Secretaria de Comunicaciones y Transportes (Secretariat of Communications and Transportation, or SCT)

- Instituto de Administración y Avalúos de Bienes Nacionales (National Asset Administration and Appraisal Institute, or INDAABIN)

- Secretaría de Agricultura, Ganadería, Desarrollo Rural, Pesca y Alimentación (Secretariat of Agriculture, Livestock, Rural Development, Fishing and Food, or SAGARPA);

- Secretaría de Desarrollo Social (Secretariat of Social Development, or SEDESOL);

- Secretaría de Turismo (Secretariat of Tourism, or SECTUR)

In addition to the CICSF, Mexico has a second intergovernmental commission of similar composition, but with an operational focus, the Comisión Intersecretarial para la Coordinación Operativa en los Puntos de Internación al Territorio Nacional (Intersecretarial Commission for the Operative Coordination at International Crossings, or CICOPI). The main objective of the CICOPI the coordination of federal agencies to improve processes, procedures and public services at maritime ports, border crossings and international airports. In addition to the agencies that participate at the CICSF, the following agencies participate at the CICOPI: the Secretaría de Marina (Secretariat of the Navy, or SEMAR); the Secretaría de Economía (Secretariat of Economy, or SE); the Procuraduría General de la República (Attorney General's Office, or PGR); the Secretaría de Hacienda y Crédito Público (Secretariat of Finance, or SCHP); the Secretaría de Salud (Secretariat of Health, or SS); and the Secretaría de la Función Pública (Secretariat of Public Administration).

It is clear that from the Mexican federal regulatory framework perspective, there is a need to find a Mexican sponsor for the FSS project (e.g. the City of Juarez, or the State of Chihuahua). 
Once a Mexican sponsor is identified, one the next step would be for both the American and the Mexican sponsors of the project to bring it up at the BBBXG.

Mexican law allows private sector participation in the construction, financing, operation and maintenance of transportation infrastructure, including border crossing infrastructure. This usually accomplished through BOT-type concessions, with renewable concession periods that last up to 30 years. In terms of foreign investment, the Mexican Foreign Investment Law (FIL) is the legal framework that regulates foreign investment. ${ }^{2}$ Foreign investors are allowed to invest in land transportation for freight. Furthermore, international and cross border freight is allowed (Title One, Chapter 2, Article 6, Section I) (16). In terms of infrastructure, the unique nature of the FSS system, made it difficult to find a relevant definition in the FIL. However, the law allows foreign investors to own up to $49 \%$ in ventures for the construction, operation and exploitation of general railways, and public services of railway transportation. Participation in excess of $49 \%$ is possible, if a favorable resolution by the National Foreign Investment Commission can be obtained (Title One, Chapter 3, Article 8, Section XII) (16).

\section{State of Chihuahua - State and Local Legal Framework}

The State of Chihuahua state and local laws relevant to the planning and implementation of the FSS system are summarized in Table 18. The table presents the name of the law or regulation in English (with the original name in Spanish within parenthesis), followed by a short description of the law, and concluding with a summary of how the law or regulation relates to the implementation of the FSS project.

\footnotetext{
${ }^{2}$ Under the FIL, a permit from the SRE is required for credit institutions to acquire, as trustees for the foreign investors, the rights to real estate located within the Restricted Zone, when the purpose of the trust is to allow the use and development of such property without constituting ownership rights. The Restricted Zone is defined by the Mexican law as the strip of national territory one hundred kilometers wide along the borders and fifty kilometers wide along the coast, as referred to in Section I of Article 27 of the Mexican Constitution. Use and development of real estate in the restricted zone shall be understood as the rights for the enjoyment of any revenue resulting operations and exploitation. Ciudad Juarez is within the restricted Zone.
} 
Table 18. Relevant State of Chihuahua State and Local Laws and Regulations

\begin{tabular}{|c|c|c|}
\hline $\begin{array}{l}\text { Law, Code, or } \\
\text { Regulation }\end{array}$ & Definition & $\begin{array}{l}\text { Relationship to the FSS } \\
\text { Implementation }\end{array}$ \\
\hline $\begin{array}{l}\text { State of Chihuahua } \\
\text { Constitution } \\
\text { (Constitución Política } \\
\text { del Estado Libre y } \\
\text { Soberano de } \\
\text { Chihuahua). }\end{array}$ & $\begin{array}{l}\text { The state constitution stipulates the powers given to } \\
\text { municipalities in regards with the formulation, } \\
\text { promotion, approval, and administration of urban } \\
\text { development projects as well as the zoning and land } \\
\text { uses. This document also mandates municipalities } \\
\text { the creation of a Plan for Urban Development of the } \\
\text { municipality, and to include all major projects in } \\
\text { such plan. Finally, relative to the FSS project, the } \\
\text { State of Chihuahua Constitution stipulates the type of } \\
\text { responsibilities that the municipality might acquire. }\end{array}$ & $\begin{array}{l}\text { Prior to starting the approval process } \\
\text { for the project a Mexican project } \\
\text { sponsor must be identified. Possible } \\
\text { sponsors include the City of Juarez } \\
\text { or the State of Chihuahua. }\end{array}$ \\
\hline $\begin{array}{l}\text { Municipal Codes } \\
\text { (Código Municipal para } \\
\text { el Estado de } \\
\text { Chihuahua). }\end{array}$ & $\begin{array}{l}\text { This code stipulates the powers given to } \\
\text { municipalities to approve the Plan for Urban } \\
\text { Development of the municipality; request to the State } \\
\text { Legislature an expansion of the municipalities' legal } \\
\text { framework; allows the major of each municipality to } \\
\text { send to the state government branch the projects that } \\
\text { require its coordination; establish that the director of } \\
\text { urban development has the authority to confer } \\
\text { licenses for construction of a project and to suspend } \\
\text { a project if it not complies with all applicable laws } \\
\text { and regulations; it stipulates that a committee for } \\
\text { urban development can be formed by representatives } \\
\text { of the public and private sectors and such committee } \\
\text { can participate in the creation of the Plan for Urban } \\
\text { Development of the municipality. }\end{array}$ & $\begin{array}{l}\text { The FSS project must be approved } \\
\text { by the director of urban } \\
\text { development, and any permission for } \\
\text { construction of the FSS project } \\
\text { might be obtained from the director } \\
\text { of urban development. }\end{array}$ \\
\hline $\begin{array}{l}\text { Planning Law for the } \\
\text { State of Chihuahua } \\
\text { (Ley de Planeación del } \\
\text { Estado de Chihuahua). }\end{array}$ & $\begin{array}{l}\text { Stipulates that development plans at state and } \\
\text { municipal levels must be aligned in principle with } \\
\text { the State of Chihuahua Constitution; it makes } \\
\text { reference to the State Planning System and specifies } \\
\text { roles and responsibilities and emphasize the } \\
\text { participation of social groups in the creation of the } \\
\text { Plan for Urban Development of the municipalities. }\end{array}$ & $\begin{array}{l}\text { The FSS must be aligned, or } \\
\text { included, with the principles of the } \\
\text { Chihuahua State Planning System. }\end{array}$ \\
\hline $\begin{array}{l}\text { Law of Urban } \\
\text { Development for the } \\
\text { State of Chihuahua. } \\
\text { (Ley de Desarrollo } \\
\text { Urbano del Estado de } \\
\text { Chihuahua). }\end{array}$ & $\begin{array}{l}\text { Establish the norms for land use planning and the } \\
\text { creation, maintenance, improvements, and growth of } \\
\text { the metropolitan areas; it designate the Secretariat for } \\
\text { Urban Development and the Environment as the } \\
\text { agency in charge of the application of this law; } \\
\text { moreover, as the entity in charge of achieving } \\
\text { resolutions of urban and environmental impact } \\
\text { assessments. The state government determines if the } \\
\text { Plan for Urban Development of the municipalities is } \\
\text { aligned with the state plans. It stipulates the } \\
\text { consideration of Zoning Codes and Plan for Urban } \\
\text { Development as well as the content that each must } \\
\text { consider. It establish the legal procedure for the } \\
\text { creation, updating, and approval of the Plan for } \\
\text { Urban Development, including: public outreach of } \\
\text { the projects in the plan, answer the concerns of the } \\
\text { community; request a resolution stating its } \\
\text { congruence with the State Plans, registration in the } \\
\text { Property Public Register, finally its published in the } \\
\text { State Register Newspaper. }\end{array}$ & $\begin{array}{l}\text { The FSS project must be revised by } \\
\text { the State of Chihuahua Secretariat } \\
\text { for Urban Development and the } \\
\text { Environment to ensure compliance } \\
\text { with this law. }\end{array}$ \\
\hline
\end{tabular}




\begin{tabular}{|c|c|c|}
\hline $\begin{array}{l}\text { Law, Code, or } \\
\text { Regulation }\end{array}$ & Definition & $\begin{array}{l}\text { Relationship to the FSS } \\
\text { Implementation }\end{array}$ \\
\hline $\begin{array}{l}\text { Law of Acquisitions, } \\
\text { Leasing, and Urban } \\
\text { Development } \\
\text { Contracts of the State } \\
\text { of Chihuahua. (Ley de } \\
\text { Adquisiciones, } \\
\text { Arrendamientos, } \\
\text { Contratación de } \\
\text { Servicios y Obra } \\
\text { Pública del Estado de } \\
\text { Chihuahua). }\end{array}$ & $\begin{array}{l}\text { Stipulates that properties acquisition, leasing and } \\
\text { services, and urban development must be aligned } \\
\text { with the National Infrastructure Plan, the State } \\
\text { Development Plan and the Plan for Urban } \\
\text { Development of the municipality. }\end{array}$ & $\begin{array}{l}\text { The FSS will need to be considered } \\
\text { as part of the Plan of Urban } \\
\text { Development of Ciudad Juarez, the } \\
\text { Plan of Urban Development of the } \\
\text { State of Chihuahua, and the National } \\
\text { Infrastructure Plan. }\end{array}$ \\
\hline $\begin{array}{l}\text { Municipal Code of } \\
\text { Environmental } \\
\text { Protection of Ciudad } \\
\text { Juarez. (Reglamento } \\
\text { Municipal de Ecología } \\
\text { y Protección al } \\
\text { Ambiente del } \\
\text { Municipio de Juárez, } \\
\text { Chih.). }\end{array}$ & $\begin{array}{l}\text { The Ciudad Juarez Secretariat for Urban } \\
\text { Development and the Environment stipulates } \\
\text { regulatory guidelines for sustainable and ecological } \\
\text { development identifying ecosystems and water } \\
\text { sources within the municipality; the planned use for } \\
\text { each zone; and the environmental impact generated } \\
\text { by urban growth. It states if someone cause damage } \\
\text { to ecosystems must pay the restoration costs } \\
\text { including damages generated by industrial } \\
\text { developments. }\end{array}$ & $\begin{array}{l}\text { The implementation of the FSS must } \\
\text { not impact ecosystems or water } \\
\text { sources, and its terminals must be } \\
\text { located in zones do not designated as } \\
\text { ecological reserves. If } \\
\text { implementation takes place over } \\
\text { existing ROW and using structures } \\
\text { at the Zaragoza POE, an } \\
\text { environmental impact assessment } \\
\text { might not be necessary since } \\
\text { infrastructure in place might have } \\
\text { environmental clearance already. }\end{array}$ \\
\hline $\begin{array}{l}\text { Municipal Building } \\
\text { and Construction } \\
\text { Code of Ciudad } \\
\text { Juarez. (Reglamento de } \\
\text { Construcción para el } \\
\text { Municipio de Juárez, } \\
\text { Chihuahua). }\end{array}$ & $\begin{array}{l}\text { It provides powers to the municipality of Ciudad } \\
\text { Juarez to authorize the construction, renovation, } \\
\text { expansion, etc. of all public or private constructions } \\
\text { through the Municipal Secretariat for Urban } \\
\text { Development aligned with the regulations stipulate } \\
\text { in this code. The Municipal Secretariat for Urban } \\
\text { Development would authorize or deny the } \\
\text { permission for the construction of any construction } \\
\text { project according to regulations established in this } \\
\text { code, the Plan for Urban Development, and the laws } \\
\text { mentioned above. }\end{array}$ & $\begin{array}{l}\text { The municipality of Ciudad Juarez } \\
\text { must authorize the FSS project } \\
\text { through the Municipal Secretariat } \\
\text { for Urban Development. }\end{array}$ \\
\hline
\end{tabular}

\subsection{COMMERCIAL BORDER CROSSING-INSTITUTIONS}

Numerous government institutions directly or indirectly influence the operation of POEs. Additionally, there are a number of private sector stakeholders involved in the cross-border supply chain link of U.S. - Mexico trade and logistics. This section presents an assessment of public and private stakeholders currently involved in cross-border freight movement, and describes their existing practices and processes. This section also presents a stakeholder mapping analysis to determine which stakeholders require greater attention for the successful implementation of the system.

\section{Stakeholder Analysis}

The stakeholder analysis was performed based on a review of available literature, on-site visits, and interviews performed with stakeholders in the El Paso - Ciudad Juarez border region. 
For the purpose of this analysis, stakeholders were classified in three general categories: a) U.S. institutions; b) Mexican institutions; and c) private sector. The paragraphs that follow describe the role of the main stakeholders in each of these categories.

\section{U.S. Institutions}

There are multiple U.S. institutions that partake in the commercial land border crossing process and understanding the parts of the process where they participate is essential for the stakeholder analysis. Box 2 describes the U.S. portion of the current commercial land border crossing process and the U.S. institutions involved in the process, summarizing their roles and responsibilities. For the purpose of the stakeholder analysis, U.S. institutions were classified into five categories according their potential role in the border crossing process vis-à-vis the FSS system: (i) management and operations; (ii) planning; (iii) regulation; (iv) administration/ ownership; and (v) implementation. Table 19 defines the U.S. institutional stakeholders, summarizes their general roles and responsibilities, and categorizes them according to their potential particular role in the FSS system.

\section{Box 2: U.S. Institutions Involved in the Northbound Border Crossing Process}

A number of U.S. institutional stakeholders are involved in different parts of the border-crossing process. Currently, freight entering the country by truck is subject to several inspections by multiple agencies at the POE. The first set of inspections is performed by DHS, and consists of up to two levels of inspection thoroughness: primary inspection and secondary inspection. The primary inspection is performed by a DHS agent on all truck traffic entering the country, and generally consists of three steps: (i) an interview to the truck driver; (ii) a review of both driver and cargo documentation; and (iii) a visual inspection of the vehicle to ensure the cargo matches the documents presented, and that no illegal activity is taking place. If the agent determines during the primary inspection that the shipment merits a more thorough revision, the truck is diverted to the secondary inspection lane, where other U.S. federal agencies may join the DHS inspector (e.g. Department of Agriculture (USDA), the Food and Drug Administration (FDA), the Environmental Protection Agency (EPA), etc.). At the commercial POEs in El Paso, these inspections are carried out in facilities adjacent to the port, in most cases using non-intrusive inspection technology (such as X-Ray and VACIS gamma ray scanning devices), and loading/unloading docks.

In the State of Texas, a second set of separate commercial vehicle inspections is conducted by the U.S. Department of Transportation (DOT) Federal Motor Carrier Safety Administration (FMCSA) and the Texas Department of Public Safety (DPS). The first of these inspections is conducted by the FMCSA within the U.S. federal POE compound, and is aimed at verifying that northbound trucks comply with U.S. federal commercial vehicle safety regulations. The second inspection is conducted by the Texas DPS in a separate state-owned facility located right next to the federal POE compound, and is aimed at verifying that northbound trucks comply with state commercial vehicle safety regulations. In other U.S. states, the federal and state commercial vehicle inspection facilities are colocated and the two safety inspections are conducted simultaneously. After completing the state safety inspections, the vehicles have completed the border crossing process and are released to the local U.S. roadway network.

Once released from the U.S. POE and the commercial vehicle inspection facilities, shipments destined for plants, warehouses or distribution centers in the U.S. commercial zone are delivered. Trailers with final destinations in the interior of the country (beyond the 12 to 26 mile commercial zone skirting the border) are transferred to a U.S. longhaul carrier's border depot. Delivery is scheduled and the U.S. carrier transports the shipment to its final destination. Recently, the U.S. DOT published an initial concept document for a long haul cross-border trucking program to allow Mexican domiciled vehicles provide service beyond the 12 to 26 mile commercial zone skirting the border, and simultaneously prioritizes safety, while satisfying the United States' international obligations (17). 
Table 19. U.S. Institutional Stakeholders in the Mexico-U.S. Border Crossing Process

\begin{tabular}{|c|c|c|}
\hline U.S. Public Agencies & Stakeholder Role/Responsibility & $\begin{array}{c}\text { Potential FSS } \\
\text { Involvement }\end{array}$ \\
\hline $\begin{array}{l}\text { U.S. Department of } \\
\text { Homeland Security } \\
\text { (DHS) }\end{array}$ & $\begin{array}{l}\text { Prevent and deter terrorist attacks and protect against and } \\
\text { respond to threats and hazards to the Nation; furthermore, } \\
\text { secure national borders while welcoming lawful } \\
\text { immigrants, visitors, and trade. }\end{array}$ & $\begin{array}{l}\text { Operations and } \\
\text { Regulation }\end{array}$ \\
\hline $\begin{array}{l}\text { U.S. Customs and } \\
\text { Border Protection (CBP) }\end{array}$ & $\begin{array}{l}\text { Ensures goods and services entering or exiting the U.S. } \\
\text { abides by laws and pay applicable duties and taxes keeping } \\
\text { terrorists and their weapons out of the U.S. It also has a } \\
\text { responsibility for securing and facilitating trade and travel } \\
\text { while enforcing trade laws that protect the economy, the } \\
\text { health and safety. }\end{array}$ & $\begin{array}{l}\text { Operations and } \\
\text { Regulation }\end{array}$ \\
\hline $\begin{array}{l}\text { U.S. Department of } \\
\text { Agriculture (USDA) }\end{array}$ & Inspects animals, plants, related products entering the U.S. & $\begin{array}{l}\text { Operations and } \\
\text { Regulation }\end{array}$ \\
\hline $\begin{array}{l}\text { Food and Drug } \\
\text { Administration (FDA) }\end{array}$ & Regulates entry of food, drugs, or bio products into the U.S. & $\begin{array}{l}\text { Operations and } \\
\text { Regulation }\end{array}$ \\
\hline $\begin{array}{l}\text { Environmental } \\
\text { Protection Agency } \\
\text { (EPA) }\end{array}$ & Regulates transportation of hazardous materials in the U.S. & $\begin{array}{l}\text { Operations and } \\
\text { Regulation }\end{array}$ \\
\hline $\begin{array}{l}\text { General Services } \\
\text { Administration (GSA) }\end{array}$ & Designs, owns, and operates U.S. ports of entry & $\begin{array}{l}\text { Planning and } \\
\text { Administration/ } \\
\text { Ownership }\end{array}$ \\
\hline $\begin{array}{l}\text { Department of } \\
\text { Transportation (DOT) }\end{array}$ & $\begin{array}{l}\text { Ensures a fast, safe, efficient, accessible and convenient } \\
\text { transportation system that meets the vital national interests } \\
\text { of the U.S. }\end{array}$ & $\begin{array}{l}\text { Planning, Operations } \\
\text { and Regulation }\end{array}$ \\
\hline $\begin{array}{l}\text { U.S. Department of State } \\
\text { (DOS) }\end{array}$ & $\begin{array}{l}\text { Authorize Presidential permits for the construction, } \\
\text { connection, operation, and maintenance of facilities on the } \\
\text { U.S.-Mexico border. }\end{array}$ & Regulation \\
\hline $\begin{array}{l}\text { State Government } \\
\text { (Texas Secretary of } \\
\text { State) }\end{array}$ & $\begin{array}{l}\text { Authorize State permits for the construction, connection, } \\
\text { operation, and maintenance of facilities on the U.S.-Mexico } \\
\text { border. }\end{array}$ & Regulation \\
\hline $\begin{array}{l}\text { Texas Department of } \\
\text { Transportation } \\
\text { (TxDOT) }\end{array}$ & $\begin{array}{l}\text { Plan, develop, operate and maintain transportation } \\
\text { infrastructure linking the POE to the state roadway } \\
\text { network. Possibly lease Right-of-Way for FSS guideway. }\end{array}$ & $\begin{array}{l}\text { Planning, } \\
\text { Implementation, } \\
\text { Operations and } \\
\text { Regulation }\end{array}$ \\
\hline $\begin{array}{l}\text { El Paso Metropolitan } \\
\text { Planning Organization } \\
\text { (MPO) }\end{array}$ & $\begin{array}{l}\text { Prepare long range plans for transportation infrastructure } \\
\text { linking the POE to the MPO planning area's transportation } \\
\text { network, and for improving the existing POE infrastructure } \\
\text { as well as the construction of new POEs. }\end{array}$ & Planning \\
\hline City of El Paso & $\begin{array}{l}\text { Plan, develop, operate and maintain transportation } \\
\text { infrastructure linking the POE to the city street and } \\
\text { roadway network. Plan, develop and operate POE } \\
\text { infrastructure within its jurisdiction. Enforce local traffic } \\
\text { and safety laws. Possibly lease Right-of-Way for FSS } \\
\text { guideway. }\end{array}$ & $\begin{array}{l}\text { Planning, } \\
\text { Implementation, and } \\
\text { Operations }\end{array}$ \\
\hline
\end{tabular}


U.S. Public Agencies

\begin{tabular}{|l|l|l|}
\hline County of EI Paso & $\begin{array}{l}\text { Plan, develop, operate and maintain transportation } \\
\text { infrastructure linking the POE to the city street and } \\
\text { roadway network. Plan, develop and operate POE } \\
\text { infrastructure within its jurisdiction. Enforce local traffic } \\
\text { and safety laws. }\end{array}$ & $\begin{array}{l}\text { Planning, } \\
\text { Implementation, and } \\
\text { Operations }\end{array}$ \\
\hline $\begin{array}{l}\text { Camino Real Regional } \\
\text { Mobility Authority } \\
\text { (CRRMA) }\end{array}$ & $\begin{array}{l}\text { Develop, finance, operate and maintain transportation } \\
\text { infrastructure linking the POE to the city street and } \\
\text { roadway network, as well as POE infrastructure within its } \\
\text { jurisdiction. }\end{array}$ & $\begin{array}{l}\text { Implementation and } \\
\text { Operations }\end{array}$ \\
\hline $\begin{array}{l}\text { U.S. Citizenship and } \\
\text { Immigration Services } \\
\text { (USCIS) }\end{array}$ & $\begin{array}{l}\text { Regulates entry of visitors and immigrants into the U.S. and } \\
\text { prevents unlawful employment. }\end{array}$ & None \\
\hline $\begin{array}{l}\text { Department of Public } \\
\text { Safety (DPS) }\end{array}$ & $\begin{array}{l}\text { Enforce state motor carrier, driver, and vehicle safety } \\
\text { regulations. }\end{array}$ & None \\
\hline
\end{tabular}

\section{Mexican Institutions}

Similarly, on the Mexican side of the border, there are also a number of institutions involved in the commercial border crossing process. The current process and institutional roles and responsibilities are described in Box 3 below. For the purpose of the stakeholder analysis, Mexican institutions were classified according their potential role in the border crossing process vis-à-vis the FSS system into the same five categories as the U.S. institutions: (i) management and operations; (ii) planning; (iii) regulation; (iv) administration/ ownership; and (v) implementation. Table 20 defines the Mexican institutional stakeholders, summarizes their general roles and responsibilities, and categorizes them according to their potential particular role in the FSS system

\section{Box 3: Mexican Institutions Involved in the Border Crossing Process}

Cargo crossing the border might be generated by maquiladoras located in Ciudad Juarez, or in the interior of the country, most probably in the City of Chihuahua. Long-haul trucking companies transport the freight to a warehouse situated near the border. Mexican and U.S. customs brokers are hired by the maquiladoras (or other shippers) to file the export and import documentation respectively. Once the export and import documentation is complete, drayage trucking companies are hired to move cargo across the border. Before arriving to the Mexican Customs export compound, a security inspection performed to the trucks by private companies hired by the maquiladoras is performed, usually using trained dogs owned by the security companies. Subsequently, the trucks arrive to the Mexican export compound where shipments' documentation is revised by a Mexican custom agent (unlike its U.S. counterparts Mexican customs inspect outbound cargo), and it is subject to a random selection mechanism (red light/green light system). Less than 10 percent of shipments are selected for export inspections (18).

Trucks exiting the Mexican export compound move across the border to the U.S. POE facilities to continue with the U.S. importation process. Conversely, trucks entering Mexico are subject to inspections and regulations established by Mexican Customs (Aduana) - a federal agency under the Tax Administration Service (SAT), whose main functions include to inspect, collect duties, and regulate the movement of goods entering or leaving Mexico ensuring compliance with Mexican laws. Mexican Customs also monitors the movement of U.S. trucks used to transport goods into Mexico ensuring they return to the U.S. 
Table 20. Mexican Institutional Stakeholders in the Mexico-U.S. Border Crossing Process

\begin{tabular}{|c|c|c|}
\hline Mexican Public Agencies & Stakeholder Role or Responsibility & $\begin{array}{l}\text { Potential FSS } \\
\text { Involvement }\end{array}$ \\
\hline $\begin{array}{l}\text { Secretaría de Hacienda y } \\
\text { Crédito Público (SHCP) - } \\
\text { Aduana Mexico }\end{array}$ & $\begin{array}{l}\text { Ensures goods and services entering or exiting Mexico } \\
\text { abides by laws and pay applicable duties and taxes. It } \\
\text { also has a responsibility for securing and facilitating } \\
\text { trade and travel while enforcing trade laws that protect } \\
\text { the economy and security. Mexican counterpart of U.S. } \\
\text { Customs. }\end{array}$ & $\begin{array}{l}\text { Operations and } \\
\text { Regulation }\end{array}$ \\
\hline $\begin{array}{l}\text { Secretaría de Agricultura, } \\
\text { Ganadería, Desarrollo Rural } \\
\text { Pesca(SAGARPA) }\end{array}$ & $\begin{array}{l}\text { Conducts phytosanitary inspections of plant and meat } \\
\text { products - Mexican counterpart of USDA. }\end{array}$ & $\begin{array}{l}\text { Operations and } \\
\text { Regulation }\end{array}$ \\
\hline $\begin{array}{l}\text { Caminos y Puentes Federales } \\
\text { de Ingresos y Servicios } \\
\text { Conexos (CAPUFE) }\end{array}$ & $\begin{array}{l}\text { Administration, operation, and maintenance of federal } \\
\text { toll roads and international bridges. }\end{array}$ & $\begin{array}{l}\text { Planning, } \\
\text { Implementation, and } \\
\text { Operations }\end{array}$ \\
\hline $\begin{array}{l}\text { Secretaría del Medio } \\
\text { Ambiente y Recursos } \\
\text { Naturales (SEMARNAT) }\end{array}$ & $\begin{array}{l}\text { Regulation of hazardous materials and fumigation of } \\
\text { forest products - Mexican counterpart of EPA. }\end{array}$ & Regulation \\
\hline $\begin{array}{l}\text { Instituto Nacional de } \\
\text { Avalúos de Bienes } \\
\text { Nacionales (INDABIN) }\end{array}$ & $\begin{array}{l}\text { Manages and operates Mexican port of entry facilities - } \\
\text { Mexican counterpart of GSA. }\end{array}$ & $\begin{array}{l}\text { Planning and } \\
\text { Administration/ } \\
\text { Ownership }\end{array}$ \\
\hline $\begin{array}{l}\text { Instituto Nacional de } \\
\text { Migración (INM) }\end{array}$ & $\begin{array}{l}\text { Administers and enforces Mexican immigration } \\
\text { regulations - Mexican counterpart of USCIS. }\end{array}$ & None \\
\hline $\begin{array}{l}\text { Secretaría de } \\
\text { Comunicaciones y } \\
\text { Transportes (SCT) }\end{array}$ & $\begin{array}{l}\text { Plan, develop, operate and maintain transportation } \\
\text { infrastructure linking the POE to the Mexican federal } \\
\text { roadway network.- Mexican counterpart of DOT and } \\
\text { CAPUFE's parent agency. Possibly lease Right-of-Way } \\
\text { for FSS guideway. }\end{array}$ & $\begin{array}{l}\text { Planning, } \\
\text { Implementation, } \\
\text { Operations and } \\
\text { Regulation }\end{array}$ \\
\hline $\begin{array}{l}\text { Gobierno del Estado de } \\
\text { Chihuahua (Chihuahua } \\
\text { State) }\end{array}$ & $\begin{array}{l}\text { Plan, develop, operate and maintain transportation } \\
\text { infrastructure linking the POE to the city street and } \\
\text { roadway network. Enforce local traffic and safety laws. } \\
\text { Possibly lease Right-of-Way for FSS guideway. }\end{array}$ & $\begin{array}{l}\text { Planning, } \\
\text { Implementation, and } \\
\text { Operations }\end{array}$ \\
\hline $\begin{array}{l}\text { Municipio de Ciudad Juárez } \\
\text { (City of Juárez) }\end{array}$ & $\begin{array}{l}\text { Plan, develop, operate and maintain transportation } \\
\text { infrastructure linking the POE to the city street and } \\
\text { roadway network. Enforce local traffic and safety laws. } \\
\text { Possibly lease Right-of-Way for FSS guideway. }\end{array}$ & $\begin{array}{l}\text { Planning, } \\
\text { Implementation, and } \\
\text { Operations }\end{array}$ \\
\hline $\begin{array}{l}\text { Juarez Metropolitan } \\
\text { Planning Organization } \\
\text { (IMIP) }\end{array}$ & $\begin{array}{l}\text { IMIP has the mandate to Develop the Regional } \\
\text { Development Plan for Ciudad Juarez. Since the FSS will } \\
\text { need to be included as part of such plan, communication } \\
\text { with IMIP will be critical. }\end{array}$ & Planning \\
\hline $\begin{array}{l}\text { Secretaria de Relaciones } \\
\text { Exteriores (SRE) }\end{array}$ & $\begin{array}{l}\text { Approve and coordinate with U.S. counterparts the } \\
\text { planning, construction, connection, operation, and } \\
\text { maintenance of POEs. Initial point of contact, and } \\
\text { approval of implementation of the FSS System. }\end{array}$ & $\begin{array}{l}\text { Planning and } \\
\text { Regulation }\end{array}$ \\
\hline
\end{tabular}




\section{Private Stakeholders}

Private sector stakeholders are the primary users of border-crossing services, and include shippers, carriers, and customs brokers. These stakeholders would also be the primary users of the FSS System. Box 4 describes the current border crossing process from the perspective of these stakeholders and highlights the factors that influence their supply chain management decision-making process, as it relates to border crossing delays. Table 21 defines these stakeholders, summarizes their general roles and responsibilities, and analyzes their potential involvement in the FSS system.

\section{Box 4: Private Sector Stakeholders Involved in the Border Crossing Process}

Incorporating the uncertainty of border crossing delays into the maquiladora supply chain management process is generally the responsibility of supply chain managers. Supply chain managers are responsible for initiating the export movement and developing routing plans, including the selection of the POE where the shipment is to cross (e.g. Zaragoza vs. Bridge of the Americas). Maquiladoras contract with drayage carriers to move their freight from the plant and across the border to the U.S.. Drayage carriers do not make decisions regarding truck routing or the selection of a POE to cross into the U.S. However, truck drivers are responsible for providing supply chain managers with continuous updates on their current location and length of border crossing queues (via cell-phone, radio, or GPS), which ultimately has some influence in the routing and POE selection process of subsequent shipments.

According to a survey conducted by TTI with maquiladora supply chain managers in the El Paso-Ciudad Juarez region, the cross-border shipping process from the maquiladora's perspective is generally characterized by:

- Supply chain manager- predefined routes to access the POE, frequently with associated with some level of visual or electronic surveillance (i.e. GPS, video) along each route, restricting trucking companies to only follow predefined routes;

- A preference to use the Bridge of the Americas (BOTA) POE because communication with Customs is perceived as better than at the Zaragoza POE, which facilitates solving administrative problems (e.g. liberate a shipment that was stopped due to paperwork issues);

- Selection of POE for crossing is made based on its proximity to the maquiladora or the final destination, truck-routes congestion, and inspections delay times, as these are constantly communicated by truck drivers to the supply chain managers;

- Selection of POE for crossing is also based on its schedule of operations. For example, when BOTA is closed, maquiladoras will use the Zaragoza-Ysleta POE (BOTA closes at 6:00 pm but trucks arriving to the queue after 4:00 pm carry significant risk of not crossing); and

- The cost of cross-border shipping (drayage) does not influence the selection of POE (i.e. the cost of shipping a load is fairly uniform regardless of the POE selected for crossing). Conversely, the cost of a delayed shipment is very significant.

Before dispatching a shipment, the maquiladora supply chain manager initiates the export documentation with a Mexican customs broker, which prepares the export documentation, the carrier's certification, and may pay export duties. There is also a U.S. custom broker involved in the process, which also files entry documentation, carrier's certification, pay export duties, and prepares the U.S. Bill of Lading and the customs manifest. A number of customs brokers that have offices on both sides of the border. Once these documents are ready, the drayage carrier picks up the trailer and hauls it across the border. Hard copy documentation is collected by the drayage driver en route to the Mexican Customs exports compound. Once in the compound, an inspection of the hard copies of the exports documentation is the first inspection by Mexican Customs (Aduana Mexico). 
Table 21. Private Stakeholders in the Mexico-U.S. Border Crossing Process

\begin{tabular}{|c|c|c|}
\hline Private Stakeholders & Stakeholder Role or Responsibility & $\begin{array}{c}\text { Potential FSS } \\
\text { Involvement }\end{array}$ \\
\hline Shipper (Maquiladora) & Loads trailer at origin and provides sales documentation. & Customers \\
\hline $\begin{array}{l}\text { Mexican and/or U.S. Drayage } \\
\text { Carrier }\end{array}$ & Shuttles cargo across border. & Customers \\
\hline Mexican Customs Brokers & Files export documentation with Mexican Customs. & Customers \\
\hline U.S. Customs Brokers & $\begin{array}{l}\text { Prepares and files import documentation with U.S. } \\
\text { Customs. }\end{array}$ & Customers \\
\hline U.S. Importers (final consignee) & May provide shipment information to customs brokers. & Customers \\
\hline Local and Long Haul Carriers & Shuttles cargo on each side of the border. & Customers \\
\hline $\begin{array}{l}\text { Shippers or Maquiladora } \\
\text { Associations }\end{array}$ & $\begin{array}{l}\text { Could serve as a link to promote the services of the FSS } \\
\text { with the Maquiladoras already established, and with the } \\
\text { ones looking to start operations in the region. }\end{array}$ & $\begin{array}{l}\text { Liaison to } \\
\text { Customers }\end{array}$ \\
\hline
\end{tabular}

\section{Stakeholder Mapping}

After identifying the institutions, organizations, and private groups likely to affect or be affected by the proposed implementation of a binational FSS system, researchers developed a stakeholder map. The objective of stakeholder mapping is to assess which stakeholders will require greater attention for the successful implementation of the system. The El Paso-Ciudad Juarez stakeholders were mapped using the following four different categories:

- High Power / High Impact. Stakeholders in this category have significant power to influence success or failure in the implementation of the system. Additionally, the effects of decisions made by these stakeholders may totally change the course of the project. For example, if the DOS opposes to the project, implementation will likely not take place, or if the DOS decides that implementation should take place in a specific location might totally change the course of the project.

- High Power / Low Impact. Stakeholders in this category have significant power to influence success or failure in the implementation of the system, however, the decisions of these stakeholders will likely have no effect on the course of the project. For example, if the shippers association opposes the project, its opposition will significantly influence the success of the project given its political power. However, they do not have the legal authority to impact the implementation of the project.

- Low Power / High Impact. Stakeholders in this category lack significant power to influence success or failure in the implementation of the system, however, the effects of their decisions could totally change course of the project. For example, if the IBWC opposes the project, this is likely to have a small influence in the decisions of other stakeholders. However, the IBWC does have the legal authority to impact the implementation of the project.

- Low Power / Low Impact. Stakeholders in this category lack significant power to influence success or failure of the system implementation. Furthermore, the effects of the 
decisions made by these stakeholders represent no threat to the course of the project. For example, if a small group of brokers opposes the project, they will likely have little influence on other stakeholders' decisions and also lack any legal authority to adversely impact the project.

The stakeholder mapping was developed based on the potential relationship of each stakeholder with a binational FSS system, first during its planning and implementation stage, and later during its operational stage. Stakeholders involved during the FSS system implementation are those that would be required during the development and implementation of the project (i.e. during project approval, and its procurement and construction), but that may not necessarily be involved on the day-to-day operations (e.g. DOS, FHWA, GSA, etc.). The planning / implementation stage stakeholder map is shown in Table 22 below.

Table 22. FSS Planning/Implementation Stage Stakeholder Map

\begin{tabular}{|c|c|c|c|c|c|}
\hline $\begin{array}{c}\text { High Power (Influence) / } \\
\text { High Impact }\end{array}$ & Country & Jurisdiction & $\begin{array}{c}\text { High Power (Influence) / } \\
\text { Low Impact }\end{array}$ & Country & Jurisdiction \\
\hline DOS & U.S. & Federal & Mexican Customs Brokers & Mexico & Private \\
\hline SRE & Mexico & Federal & U.S. Customs Brokers & U.S. & Private \\
\hline DHS-CBP & U.S. & Federal & U.S. Importers & U.S. & Private \\
\hline SHCP - Aduana Mexico & Mexico & Federal & $\begin{array}{l}\text { Shippers or Maquiladora } \\
\text { Associations }\end{array}$ & $\begin{array}{l}\text { U.S./ } \\
\text { Mexico }\end{array}$ & Private \\
\hline Texas Secretary of State & U.S. & State & Drayage Carriers & $\begin{array}{l}\text { Mexico/ } \\
\text { U.S. }\end{array}$ & Private \\
\hline City of El Paso & U.S. & Local & & & \\
\hline SCT & Mexico & Federal & & & \\
\hline DOT & U.S. & Federal & & & \\
\hline CAPUFE & Mexico & Federal & & & \\
\hline CRRMA & U.S. & Local & & & \\
\hline EPA & U.S. & Federal & & & \\
\hline SEMARNAT & Mexico & Federal & & & \\
\hline TxDOT & U.S. & State & & & \\
\hline EPMPO & U.S. & Local & & & \\
\hline County of El Paso & U.S. & Local & & & \\
\hline City of Juarez & Mexico & Local & & & \\
\hline IMIP & Mexico & Local & & & \\
\hline Chihuahua State & Mexico & State & & & \\
\hline $\begin{array}{c}\text { Low Power (Influence) / } \\
\text { High Impact }\end{array}$ & & & $\begin{array}{c}\text { Low Power (Influence) / } \\
\text { Low Impact }\end{array}$ & & \\
\hline FDA & U.S. & Federal & USCIS & U.S. & Federal \\
\hline USDA & U.S. & Federal & INM & Mexico & Federal \\
\hline DPS & U.S. & State & $\begin{array}{l}\text { Local and Long Haul } \\
\text { Carriers }\end{array}$ & $\begin{array}{l}\text { U.S./ } \\
\text { Mexico }\end{array}$ & Private \\
\hline INDABIN & Mexico & Federal & & & \\
\hline SAGARPA & Mexico & Federal & & & \\
\hline GSA & U.S. & Federal & & & \\
\hline IBWC & $\begin{array}{l}\text { U.S./ } \\
\text { Mexico }\end{array}$ & Federal & & & \\
\hline
\end{tabular}


The stakeholders involved during the operational stage of the system are many of those who are currently involved in the day-to-day operations of the commercial border-crossing process (e.g. CBP-DHS, Aduana Mexico, and Customs Brokers). Also included at this stage are those stakeholders who are responsible for managing and operating the transportation infrastructure that will feed traffic into the FSS terminals, and the right-of-way where the system's guideway would be located (e.g. TxDOT, City of Juarez). The operational stage stakeholder map is shown in Table 23 and discussed below.

Table 23. FSS Operational Stage Stakeholder Map

\begin{tabular}{|c|c|c|c|c|c|}
\hline $\begin{array}{c}\text { High Power (Influence) / } \\
\text { High Impact }\end{array}$ & Country & Jurisdiction & $\begin{array}{c}\text { High Power (Influence) / } \\
\text { Low Impact }\end{array}$ & Country & Jurisdiction \\
\hline DHS-CBP & U.S. & Federal & Mexican Customs Brokers & Mexico & Private \\
\hline SHCP - Aduana Mexico & Mexico & Federal & U.S. Customs Brokers & U.S. & Private \\
\hline City of El Paso & U.S. & Local & U.S. Importers & U.S. & Private \\
\hline SCT & Mexico & Federal & $\begin{array}{l}\text { Shippers or Maquiladora } \\
\text { Associations }\end{array}$ & $\begin{array}{l}\text { U.S./ } \\
\text { Mexico }\end{array}$ & Private \\
\hline DOT & U.S. & Federal & $\begin{array}{l}\text { Local and Long Haul } \\
\text { Carriers }\end{array}$ & $\begin{array}{l}\text { U.S./ } \\
\text { Mexico }\end{array}$ & Private \\
\hline CAPUFE & Mexico & Federal & EPMPO & U.S. & Local \\
\hline TxDOT & U.S. & State & IMIP & Mexico & Local \\
\hline County of El Paso & U.S. & Local & & & \\
\hline City of Juarez & Mexico & Local & & & \\
\hline FDA & U.S. & Federal & & & \\
\hline USDA & U.S. & Federal & & & \\
\hline CRRMA & U.S. & Local & & & \\
\hline INDABIN & Mexico & Federal & & & \\
\hline GSA & U.S. & Federal & & & \\
\hline SAGARPA & Mexico & Federal & & & \\
\hline EPA & U.S. & Federal & & & \\
\hline SEMARNAT & Mexico & Federal & & & \\
\hline $\begin{array}{c}\text { Low Power (Influence) / } \\
\text { High Impact }\end{array}$ & & & $\begin{array}{c}\text { Low Power (Influence) / } \\
\text { Low Impact }\end{array}$ & & \\
\hline DOS & U.S. & Federal & USCIS & U.S. & Federal \\
\hline SRE & Mexico & Federal & INM & Mexico & Federal \\
\hline Texas Secretary of State & U.S. & State & Drayage Carriers & $\begin{array}{l}\text { Mexico/ } \\
\text { U.S. }\end{array}$ & Private \\
\hline Chihuahua State & Mexico & State & & & \\
\hline DPS & U.S. & State & & & \\
\hline IBWC & $\begin{array}{l}\text { U.S./ } \\
\text { Mexico } \\
\end{array}$ & Federal & & & \\
\hline
\end{tabular}

The operational stage stakeholder map also shows a significant number of institutional stakeholders from both sides of the border in the High Power / High Impact category. However, some of the stakeholders that in the planning / implementation stage were on this category have 
moved other categories, and stakeholders that were in other categories now appear in the High Power / High Impact category. For example, the DOS and the SRE, which were in the High Power / High Impact category during the planning / implementation stage, have moved to the Low Power / High Impact category during the operational stage, as they are not directly involved in border crossing operations, and consequently their level of influence has decreased. Another shift in the map worth noting is that of the drayage carriers and the local/long haul carriers, who have traded places, moving from the High Power / Low Impact category to the Low Power / Low Impact category and vice versa. By the time the FSS system moves into its operational stage, some of the drayage carriers will likely enter the local/long haul carrier stakeholder group.

\subsection{BINATIONAL INSTITUTIONAL MODEL FOR OPERATIONS}

The complexity of the regulatory and institutional framework for border crossing infrastructure and operations indicates that the implementation of the FSS is likely to be a complex undertaking. The FSS concept challenges the notion of current border crossing practices and consequently there is a need to develop an institutional model that clearly defines the role of the system vis-à-vis existing public and private sector institutions. This section presents a conceptual institutional model for the operation of the FSS system within the current regulatory and institutional framework. The model outlines the possible role of U.S. and Mexican government agencies that would likely be involved on the day-to-day cross border operation of the system (e.g. the role of customs agencies in the inspect-in-motion facilities).

The binational institutional model for FSS operations would involve six basic functions: ownership; financing; design and construction; operations, inspection and enforcement; and local transportation. For the purpose of developing this conceptual institutional model, these functions have been preliminarily allocated to different public and private sector entities in each side of the border, as shown in Figure 28. These functions are explained in more detail below along with the public and private sector entities in the U.S. and Mexico that would be responsible for each.

- Ownership. This function refers to the party who ultimately bears legal title to the main system assets, which are broadly defined as follows:

- Technologies - The FSS technologies are licensed by FSI, a private firm that has the right to license the technology (i.e. transporters, terminal designs, rotating cargo bays, etc.) to independent operators. As such, the technology itself remains owned by FSI.

- Terminals - The definition of terminals includes the property where the terminal is located, as well as the infrastructure, superstructures, and equipment located within the property. These facilities are assumed to be owned by the FSS licensee on each side of the border, regardless of whether they are actually owned by the licensee or simply leased from a third party.

- Guideways - The definition of guideways includes the support structures, guideway and other system infrastructure located outside the terminals on each side of the border, including right-of-way on the facility crossing the border (e.g. the Zaragoza-Ysleta POE). It is recognized that depending on the 
location of the right-of-way and the right-of-way leasing agreement, particularly above the border crossing itself, ownership of the guideway could vary. However, for the purposes of this discussion, it is assumed that the guideways would be owned by the FSS licensees, or by a governmental entity in the U.S. and Mexico.

- Right-of-Way - The right of way over which the guideways are built are generally assumed to be owned by local, state or federal government entities. For example, the right-of-way in sections of El Paso over a state highway (e.g. Loop 375), would be owned by TxDOT. Right-of-way over the ZaragozaYsleta International Bridge in the U.S. up to the international boundary line would be owned by the City of El Paso, while the section located on the Mexican side of the border within the same facility would be owned by the Mexican federal government and concessioned to Promofront, a Mexican private international bridge operator. Right-of-way for portions of the guideway in Ciudad Juarez would be owned by the municipality, the Chihuahua State government, or the Mexican federal government.

- Transporters - The FSS transporters could be owned by the U.S. and Mexican FSS licensees or by third-party logistics providers (3PLs). These 3PLs would include current logistics and transportation companies operating in the region, including current drayage carriers.

- Inspect-in-Motion Facility - The Inspect-in-Motion facilities on each side of the border would likely be owned by the relevant federal agencies. In the U.S., GSA would likely own the facility for DHS-CBP. In Mexico, INDAABIN would likely own the facility for SCHP-Aduana Mexico.

- Financing. This function refers to how the construction and operation of the FSS system is to be financed. The FSS concept relies on a private sector project financing model for its implementation and operation. The development and construction of the project on both sides of the border would be financed by the U.S. and Mexican FSS licensees using a mix of equity and debt. Project capital and operational costs, including debt service, would be recovered from operational revenue.

- Design and Construction. This function refers to the design and construction of the FSS system, including terminals, guideways, transporters and inspect-in-motion facilities. This function is extremely important, given the specialized nature of the FSS as an infrastructure system. As project owners, the FSS licensees in the U.S. and Mexico are ultimately responsible for managing the project implementation through its completion. However, design and construction of the specialized components of the system (i.e. guideways, electrical and mechanical systems, etc.) will be managed by Freight Shuttle Services (FSS), a subsidiary of FSI, as a turnkey project for the FSS licensee. Other conventional terminal components (e.g. terminal yards, buildings) would be designed and built by local companies selected by the FSS licensees. 
- Operations. This function refers to the day-to-day operation of the system and all its different elements (i.e. terminal, guideways, and transporters). The FSS licensees on both sides of the border would subcontract with a FSS Operating Entity for the operation of the system, including: operating command, control and communication systems; operating and maintaining transporters and guideway; managing sales and marketing; storage; and communicating and coordinating with border inspection and enforcement agencies. The use of a common FSS Operating Entity (based in the U.S. with a subsidiary in Mexico) would ensure the seamless operation of the system.

- Inspection and enforcement. This function refers to the enforcement of U.S. customs and border security regulations. In the U.S. this function would be performed by DHS-CBP, with support from FDA and USDA. In Mexico, the customs inspection and enforcement function would be performed by SHCP-Aduana Mexico, and SAGARPA, while border security enforcement would likely be performed by PGR. The FSS system is envisioned to use the inspect-in-motion facility described earlier in this document, where the inspection of trailers and containers would take place.

- Local transportation. This function refers to the movement of conveyances (trailers and/or containers) to/from the shipper's warehouses and manufacturing facilities (maquiladoras) to/from the FSS terminal. This function could be performed by U.S. and Mexican local carriers, 3PLs, or the shippers/consignee's themselves. 
Function

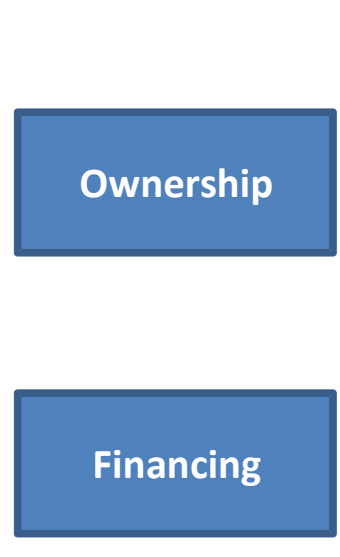

U.S. Entities

\begin{tabular}{|c|c|}
\hline $\begin{array}{c}\text { Technology: } \\
\text { Freight Shuttle } \\
\text { Partners }\end{array}$ & $\begin{array}{c}\text { Terminal: FSS U.S. } \\
\text { Licensees }\end{array}$ \\
\hline $\begin{array}{c}\text { Right-of-Way: } \\
\text { state, or local } \\
\text { government }\end{array}$ & $\begin{array}{c}\text { Transporters: } \\
\text { U.S. FSS Licensees } \\
\text { or 3PLs }\end{array}$ \\
\hline
\end{tabular}

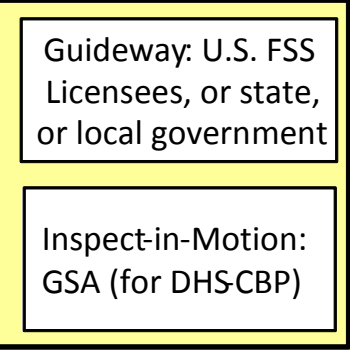

Technology:
Freight Shuttle
Partners

\begin{tabular}{|c|}
\hline Right-of-Way: \\
federal, state, or \\
local government
\end{tabular}

\section{Mexico Entities}

\begin{tabular}{|c|c|c|c|}
\hline $\begin{array}{l}\text { Equity: U.S. FSS } \\
\text { Licensee }\end{array}$ & $\begin{array}{l}\text { Debt: U.S. FSS } \\
\text { Licensee Banks }\end{array}$ & $\begin{array}{l}\text { Equity: Mexico } \\
\text { FSS Licensee }\end{array}$ & $\begin{array}{l}\text { Debt: Mexico } \\
\text { FSS Licensee } \\
\text { Banks }\end{array}$ \\
\hline $\begin{array}{l}\text { U.S. FSS } \\
\text { Licensee }\end{array}$ & $\begin{array}{c}\text { Freight Shuttle } \\
\text { Services }\end{array}$ & $\begin{array}{c}\text { Mexico FSS } \\
\text { Licensee }\end{array}$ & $\begin{array}{c}\text { Freight Shuttle } \\
\text { Services }\end{array}$ \\
\hline
\end{tabular}
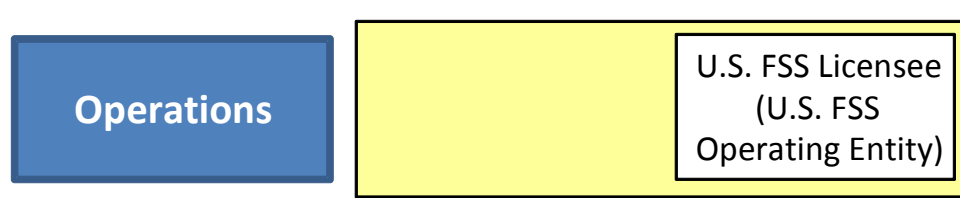

Inspection and

Enforcement

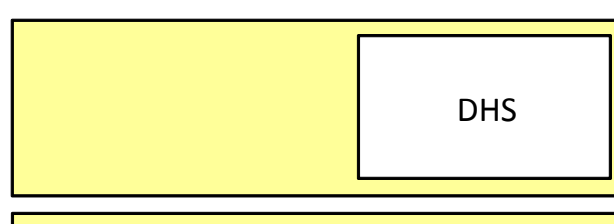

\section{Local}

Transportation
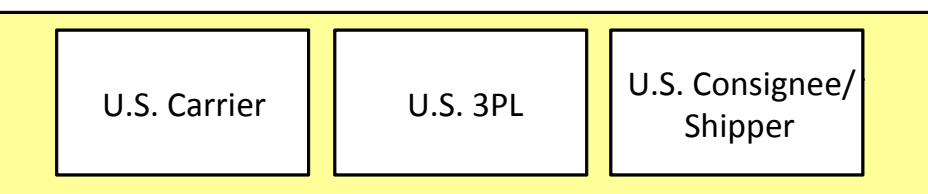

Terminal: Mexico FSS Licensees

Guideway: Mexico FSS Licensees, or federal, state, or local govt.

\begin{tabular}{c}
\hline Transporters: \\
Mexico FSS \\
Licensees or 3PLs
\end{tabular}

Inspect-in-Motion: INDAABIN (for SHCR Aduana Mexico)

\section{Figure 28. FSS Institutional Model for Binational Operations}




\subsection{BINATIONAL BUSINESS MANAGEMENT STRUCTURE}

This section presents a conceptual binational business management structure for the implementation and operation of the FSS system project. The structure defines the roles and responsibilities for the business entities that would finance, develop, operate and maintain the system, which include:

- Freight Shuttle International LLC (FSI), the entity that holds the exclusive right to license the FSS technology.

- Freight Shuttle Services LLC (FSS), a subsidiary of FSI, would be responsible for the turnkey delivery (design and construction) of Freight Shuttle systems for licensees.

- FSS Licensees or Investors in the U.S. and Mexico will finance the development of local systems and manage their operation through the FSS operating entities.

- FSS Operating Entity will manage the FSS system operations in the U.S. and Mexico.

Figure 29 illustrates the conceptual business management structure. The sections that follow define in more detail the roles and responsibilities of each entity and the relations between them.

\section{Freight Shuttle International LLC (FSI)}

As noted above, FSI is the entity that holds the exclusive right to license the FSS technology. The FSI management team has over 50 years of combined real estate development experience and long-standing relationships with pension funds, banks, and other institutional and private sources of capital. FSI has already assembled the prototype engineering team and is evaluating prospective demonstration facility locations and corridors for the construction of the first FSS prototype. FSI is currently focusing on the following activities:

- Reaching agreements with licensees or investors in key markets

- Securing additional capital for co-investment in system development through government sponsored programs targeting "Green infrastructure, major pension funds, or private equity groups.

- Forging strategic alliances with key stakeholders, government and regulatory agencies, such as the Department of transportation, Department of homeland Security, Federal Highway Administration, and on-the-ground stakeholders.

- Promoting the FSS to potential customers, such as H.E.B., Kraft, SYSCO, Wal-Mart, PepsiCo, FedEx, UPS, etc. 
- Developing and maintaining an office of innovation to advance the technology through improvements to its current intellectual property and development of new patents.

\section{Freight Shuttle Services LLC (FSS)}

Freight Shuttle Services, a subsidiary of FSI, will be in charge of planning, designing, and developing FSS systems. FSS would manage the development of local systems in the U.S. and Mexico. FSS will execute the investments associated with the acquisition of components, land, and engineering costs (non-construction) required for the construction of the FSS system. Overall, FSS is expected to deliver turnkey solutions for licensees in four main areas of implementation:

- Guideways and ROW

- Terminals-Trailer lanes

- Procurement of the FSS transporters

- Design and engineering services

\section{Licensees or Investors in the U.S. and in Mexico}

Two crucial entities in the binational management model are the FSS Licensees or Investors in the U.S. and in Mexico. The Licensees will be responsible for financing the development of their respective portions of the system. As mentioned earlier, the FSS concept has been conceived as an entirely privately financed venture. However, public support in the form of subsidies or tax breaks could play a risk mitigation role for the project, as they would help reduce the uncertainties associated with the public sector's long term commitment to the project (e.g. willingness to make right-of-way available at reasonable costs).

At the construction stage, U.S. and Mexico licensees or investors would pay FSS for the planning, design, and development of the FSS systems. Once the FSS system is built and commences operations, it will provide a long-term revenue stream to the licensees or investors. During the operational stage, licensees or investors would pay royalty fees FSI for the right to use the FSS technologies.

\section{FSS Operating Entity}

The FSS Operating Entity will be in charge of managing daily operations on both sides of the border. This entity will be based on the U.S. but having a subsidiary office in Mexico for combined operations. Combined operations include: command, control and communications; operations and maintenance of the transporters and guideway; sales and marketing; storage; and communication and coordination with border inspection and enforcement authorities on both sides of the border (i.e. DHS-CBP in the U.S., and SHCP-Aduana Mexico in Mexico).

Additionally, the FSS Operating Entity will be in charge of: administration; operations; management of financial and administrative risks; negotiation of contracts with regulators and other public agencies (e.g. right-of-way lease payments); and the negotiation of contracts with 
customers. The FSS Operating Entity could have a management board formed by members of FSI, FSS, the U.S. and Mexican Licensees, and the entity managers. Since more shipments are likely to originate in Mexico than in the U.S. (and therefore more revenue), the FS Operating Entity would also be responsible for acting as a revenue clearinghouse between the U.S. and Mexican Licensees or investors, to compensate revenue asymmetries and ensure that both entities can recover their costs and serve their debt.

\subsection{CHAPTER SUMMARY AND RECOMMENDATIONS}

This chapter provided an overview of the regulatory and institutional framework that would govern the FSS, and presented a management model for the FSS system to operate within this framework.

First, the chapter reviewed key U.S. and Mexican laws and regulations that would govern and influence the binational planning, implementation and operations of the FSS system. More specifically, this part of the chapter reviewed the processes required in the U.S. and Mexico to obtain approval for the construction of a new border crossing or the modification of an existing one. A conclusion and recommendation from this first part of the chapter is that the FSS project must find sponsors on both sides of the border, and that these sponsors need to bring the project up with the relevant national institutions (i.e. DOS and SRE) and at the BBBXG, the binational mechanism where new border crossing initiatives are coordinated between the U.S. and Mexico. A second conclusion from this part of the chapter is that private sector participation in the development, construction and operation of border crossing infrastructure is allowed in both countries.

Next, the chapter analyzes the current institutional framework for commercial border crossing operations and assesses the capacity of the different public and private sector stakeholders involved to influence the implementation or change the course of the project. This analysis identifies those stakeholders that will require greater attention for the successful implementation of the system.

The chapter concludes with a conceptual institutional model for the operation of the FSS system in a binational setting based on the findings of the regulatory and institutional analysis, and describes the proposed binational business management structure for the project, along with the roles and relationships of the different actors involved. 




Figure 29. FSS Proposed Binational Management Strategy 


\section{CHAPTER 6:}

\section{ASSESSMENT OF SECURITY AND POWER USAGE}

\subsection{OVERVIEW}

This chapter presents assessments of the security considerations of cross-border movements utilizing the FSS system and the power usage of the system. This chapter consists of the following sections:

6.2 Assessment of Security Enhancements. This section describes the envisioned security components of the FSS; how they will enhance security for cross-border movements; and the design of the security components.

6.3 Electricity Review for FSS Cross-border Operations. This section describes how the FSS power requirements fit into the existing power network.

\subsection{ASSESSMENT OF SECURITY ENHANCEMENTS}

International trade is an important part of the nation's economy. Our North American trading partners, Canada and Mexico, are both consumers of US products and suppliers of goods and material to American firms and to the public. The level of trade between the US and these neighbors to the north and south is impacted by both economic/political considerations and by the overriding need to ensure the safety and security of our country. International borders are the last lines for our national security programs and critical to ensure the integrity of international relationships and commerce. September $11^{\text {th }}$ and the drug-war in Mexico have elevated the mission of Customs and Border Protection (CBP) to an incredibly difficult-to-achieve level. Maintaining or increasing trade levels and ensuring security (of CBP personnel and US citizens) is more challenging than ever and hence, new tools and new strategies are needed to succeed.

While the Freight Shuttle is designed with congested domestic corridors as its primary focus, the system has features that lend themselves to international trade/cross border settings and facilitating the mission of CBP. The Inspect-in-Motion system described in this report facilitates the mission of CBP and reduces many of the challenges associated with today's international trade environment.

The features of the Freight Shuttle that have been identified as lending themselves to enhancing the safety and security of cross-border operations include:

8. The system is automated and has no on-board driver.

9. The system operates over a dedicated, elevated, grade separated guideway exclusively between specified locations.

10. Shipments are timed to be non-stop movements between terminal locations.

11. The system's constant high velocity lends itself to improved security.

12. The system is being developed in accordance with all C-TPAT (Customs-Trade Partnership Against Terrorism) policies and procedures. 
13. The system pushes cargo examination outward, and reduces the risk of contraband entering the US.

14. The system allows for a full NII (Non-Intrusive Inspection) examination to be conducted and a "Go or No Go" order to be issued by CBP, similar to what now happens with the CSI (Container Security Initiative).

These characteristics, if implemented in the proper international trade settings, can be used to overcome many of the challenges facing CBP in accomplishing its mission. The Inspect-inMotion concept is being developed as a means to increase inspection rates and mitigate the risks associated with the current procedures and standards of inspection. The system has the potential to move the inspection process away from congested border locations and automate many of the activities now performed by CBP personnel.

\section{Bi-National Operations}

\section{US-Mexico}

The Freight Shuttle can address a number of CBP security concerns associated with Mexico cross-border trucking operations. It can be an effective alternative to inefficient dray trucking. US-Mexico cross-border trucking presents many obstacles to secure and efficient operation.

The cancellation of the NAFTA Cross-Border Demonstration Project once again placed the prior travel restrictions back on Mexican trucks, whereby northbound Mexican trucking is restricted to a narrow commercial zone at the border. This also reinstated the complex and inefficient use of short haul drayage carriers at the border.

This process requiring northbound trucks to haul cargo to the commercial area across the border causes unnecessary delay and complexity to the supply chain and in the end increases costs for consumers. The drayage costs for 2008 alone were estimated at $\$ 739$ million (19). In addition, the current conflicts created by the Omnibus Appropriations Act, and the retaliatory tariffs placed on U.S. imports by Mexico, had an estimated cost of $\$ 2.6$ billion dollars and a loss of 25,600 jobs (19).

There is significant interest within Mexico in the Freight Shuttle as a means to enhance economic development through legitimate trade activities. The system could make secure trade with Mexico a reality and provide a cost and logistics benefit that could stabilize the economic advantage that the Pacific Rim currently holds. This approach has immediate political benefits by reducing the need for Mexican trucks to enter the US and, in the longer term, by creating jobs in Mexico that support a growing middle class, adding stability to one of our largest trading partners.

\subsection{ELECTRICITY REVIEW FOR FSS CROSS-BORDER OPERATIONS}

El Paso Electric reports that there were sales of 2,995,984 MWh to Off System customers in 2009 (24). This occurred through a total of seven Off System interconnects, as displayed in 
Figure 30. Three interconnects are to the Western Power Coordination Counsel, two are directed to ERCOT and the other two are to Mexico in Ciudad Juarez.

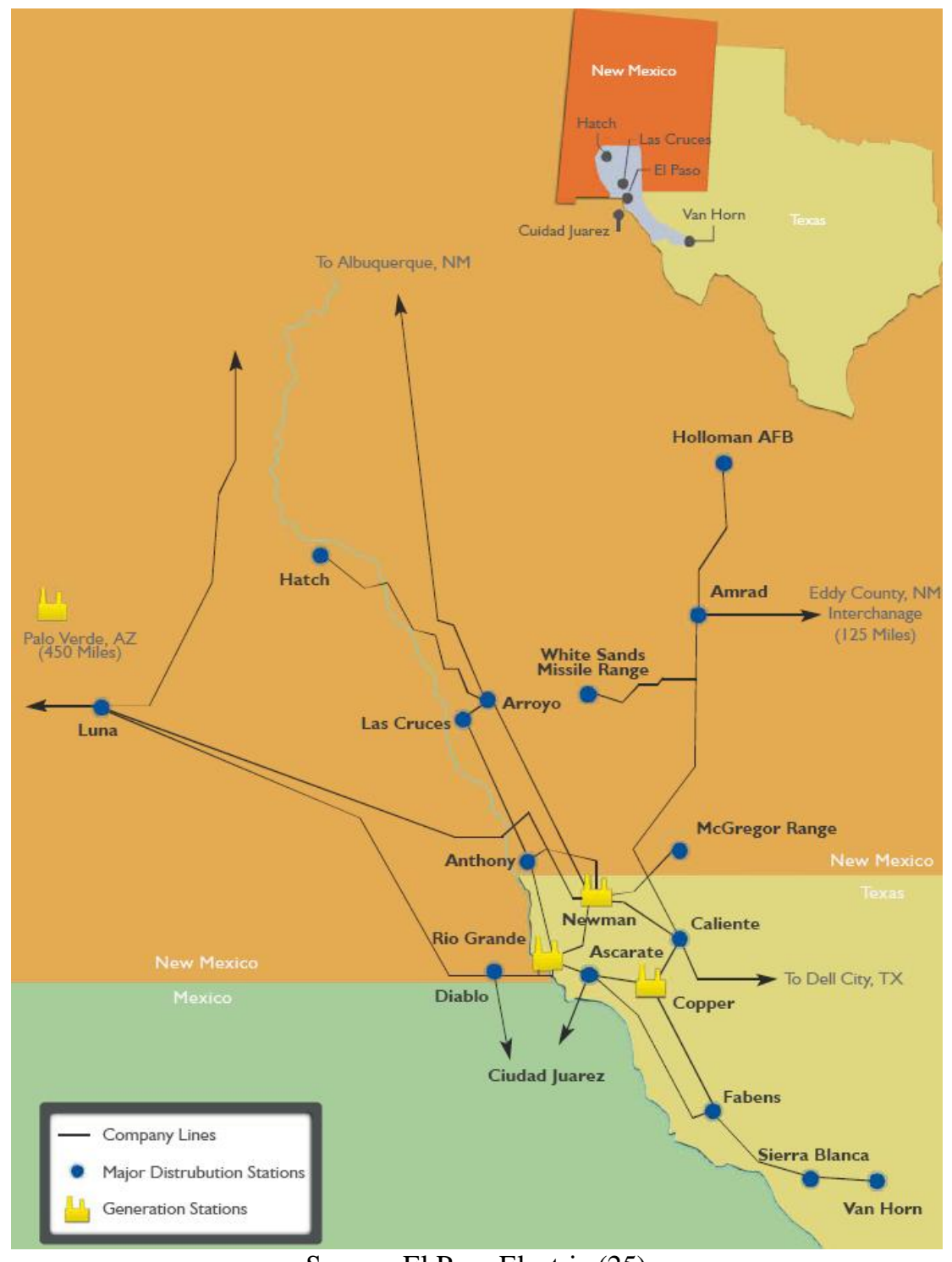

Source: El Paso Electric (25)

Figure 30. El Paso Electric Service Area

In a phone conversation in 2006, Mr. Richard Swartz, Director of Distribution and Design at El Paso Electric stated that there is currently no transfer or sales of power to Mexico. He explained that any sales (movement of power) to Mexico require government approval on both sides of the border. Additionally, the electric companies must be in agreement with the necessity of the power transfer and agree to a pricing relationship on both sides of the border to ensure financial equity in the ultimate sales transaction.

Foremost in the understanding of the movement of power across the border is this: the power moved to Mexico must be treated as an island destination. There can be no interconnect between the participating utilities. The reason the interconnect is not allowed is the Mexican side does 
not have the regulating capability (power conditioning and synchronicity of the waveform) required by the American electric governing bodies, FERC, NERC (North American Electric Reliability Council), etc.

The El Paso Electric Company has provided power to Cuidad Juarez in the past, but is not currently providing them with power. The possibility of providing the freight shuttle with a continuous power supply going across the border would require an agreement of necessity by the two countries national and state governments. The utility companies on both sides of the boarder have to agree on a method of how to meter the power consumed across the border and what an equitable sharing of the profits on the energy should take place.

Operationally, the freight shuttle should not see any difference in the power reliability as it moves throughout the guideway system. The DC conversion of power from the AC supply will likely all rest on the freight shuttle side of the power supply. El Paso Electric indicated they would not readily entertain a DC supply operation. One factor that was not clear but should be addressable by the freight shuttle engineers is the AC operating voltage to be taken from the electric utility. There seemed to be some hesitation as to what voltage the utility would want to supply if the power was going to be converted to provide a continuous DC operation at 500 to 700 v DC.

\subsection{CHAPTER SUMMARY}

The FSS system provides an opportunity to enhance the security of the goods moved across the border between The U.S. and Mexico. The driverless system will operate non-stop over an elevated guideway between secure terminals on both sides of the border. In addition to operating within existing CBP initiative, the FSS system is designed to facilitate the inspection of 100 percent of the containers that traverse the system.

This chapter also reviewed the electrical network in the El Paso region and determined that agreements with the entities on both sides of the border may be necessary to facilitate power provisions. Finally, operationally the freight shuttle should not see any difference in the power reliability as it moves throughout the guideway system. 


\section{CHAPTER 7:}

\section{BENEFITS REVIEW}

\subsection{OVERVIEW}

This chapter presents assessments of the security considerations of cross-border movements utilizing the FSS system and the power usage of the system. This chapter consists of the following sections:

7.2 Air Quality Benefits. This section describes calculated air quality benefits associated with reduced truck vehicle miles traveled and reduced truck emissions by those trucks delayed at the border crossing facilities.

7.3 Border Crossing Delay - Trucking Savings. This section describes the savings related to reducing the delays experienced by trucks at the border crossing facilities when shifted over to the FSS system.

7.4 Economic Impacts and Job Creation. This section describes the positive economic impacts and job creation possible with the construction and continued operation of the FSS system for cross-border movements.

7.5 Additional Benefits. This section describes additional benefits associated with implementing the FSS system.

7.6 Benefits Review. This section summarizes the benefits discussed throughout the chapter.

\subsection{AIR QUALITY BENEFITS}

Calculating the emissions related with truck operations involved in cross-border movements that use the FSS system includes calculating the emissions from trucks during transport; emissions from trucks delayed at the existing border crossing facilities; and emissions from power generation to power the FSS electric transporters.

\section{EI Paso Region Air Quality Concerns}

The El Paso region has multiple factors that contribute to the air quality. The Joint Advisory Committee for the Improvement of Air Quality Paso Del Norte (JAC) indicates the region known as the Paso del Norte, which includes El Paso, is located between the Franklin Mountains and the Sierras de Juarez in Mexico and is affected by topography, meteorology, economic and population pressures (20). According to the JAC, U.S. and Mexican health-based air quality standards are frequently exceeded in the Paso del Norte air basin. A report by the Center for Responsible Environmental Strategies (CRES) expands the discussion by indicating that "thermal inversions related to its topography, its desert location, meteorological conditions, and acts of God such as dry weather and high wind, contribute to the status of the air quality on any given day (21)." Additionally, the close proximity to Juarez across the border contributes to El 
Paso's air quality. The maquiladoras, brick kilns, and other industrial operations on the Mexican side of the border can negatively affect air quality in the region.

\section{Truck Emissions}

Truck VMT calculations presented in Chapter 3 provide the foundation for calculating the emissions related to transporting good across the border in El Paso. For this analysis the calculation of truck emissions use national emission rates, along with the calculated VMT values to determine the emissions created in cross-border trips for two scenarios: current cross-border operations and operations with FSS implementation. Table 24 contains the emission rates utilized in this analysis and also shows the generalized distribution of traffic per roadway type used in the analysis.

Table 24. Truck Emission Rates by Roadway Types

\begin{tabular}{|c|c|c|c|c|c|}
\hline \multirow{2}{*}{ Roadway Type } & \multirow{4}{*}{ \% Distribution } & VOC & CO & NOx & PM-10 \\
\cline { 3 - 6 } Local & 13 & 0.78 & 3.52 & 7.45 & 0.17 \\
\hline Arterial & 35 & 0.39 & 1.47 & 6.38 & 0.17 \\
\hline Urban Freeway & 30 & 0.28 & 1.14 & 8.38 & 0.17 \\
\hline Rural Freeway & 22 & 0.27 & 1.44 & 12.39 & 0.17 \\
\hline \multicolumn{7}{|c|}{ Note: 2010 rate values for combination diesel trucks } \\
\hline
\end{tabular}

Source: ICF Consulting, 2005 (22)

Additionally, the analysis calculated the carbon dioxide emissions using a previous TTI analysis. Using Environmental Protection Agency (EPA) Mobile 6.2 program for a Texasspecific corridor analysis, the carbon dioxide emission rate was calculated as 1,632.6 grams per VMT. That rate value was used as the rate for all roadway types for this analysis.

Table 25 shows the tons of emissions produced by cross-border trips by emission types over the entire 24-year evaluation period. The implementation of the FSS system will eliminate almost 87,000 tons of pollutants over the analysis period. The NOx emission factor is often discussed in areas of air quality concerns, such as El Paso. Table 25 shows that the quantity NOx would be reduced by over 446 tons with the implementation of the FSS system.

Table 25. Tons of Emissions for Current and FSS Operations Based on VMT

\begin{tabular}{|c|c|c|c|}
\hline Emission Type & Tons Current & Tons FSS & Difference (tons) \\
\hline VOC & 143.2 & 123.0 & -20.2 \\
\hline CO & 612.3 & 526.0 & -86.3 \\
\hline NOx & $3,169.1$ & $2,722.5$ & -446.6 \\
\hline PM-10 & 63.8 & 54.8 & -9.0 \\
\hline CO2 & $612,924.6$ & $526,547.7$ & $-86,376.9$ \\
\hline Total & $\mathbf{6 1 6 , 9 1 3 . 0}$ & $\mathbf{5 2 9 , 9 7 4 . 0}$ & $\mathbf{- 8 6 , 9 3 9 . 0}$ \\
\hline
\end{tabular}




\section{Border Crossings}

One of the existing conditions facing the border is the significant delay to commercial vehicles attempting to make shipments between Mexico and the U.S. A 2005 study examined the specific delays seen at the two major El Paso international bridges: BOTA and Zaragoza. The truck delay was evaluated at several segments of the trips. Table 26 shows the calculated travel times and amount of idle occurring at each trip segment across the bridges.

Table 26. Summary of Travel Time, Idling, and Creep Idling

\begin{tabular}{|c|c|c|c|c|c|c|}
\hline \multirow{2}{*}{ Section } & \multicolumn{3}{|c|}{ BOTA } & \multicolumn{3}{c|}{ Zaragoza } \\
\cline { 2 - 7 } & $\begin{array}{c}\text { Travel } \\
\text { Time (min) }\end{array}$ & $\begin{array}{c}\text { \% Normal } \\
\text { Idle }\end{array}$ & $\begin{array}{c}\text { \% Creep } \\
\text { Idle }\end{array}$ & $\begin{array}{c}\text { Travel } \\
\text { Time (min) }\end{array}$ & $\begin{array}{c}\text { \% Normal } \\
\text { Idle }\end{array}$ & $\begin{array}{c}\text { \% Creep } \\
\text { Idle }\end{array}$ \\
\hline 1 & 8.5 & $41 \%$ & $18 \%$ & 11.1 & $36 \%$ & $13 \%$ \\
\hline 2 & 8.2 & $62 \%$ & $13 \%$ & 23.0 & $75 \%$ & $8 \%$ \\
\hline 3 & 4.2 & $13 \%$ & $29 \%$ & - & - & - \\
\hline Total & 21.0 & $45 \%$ & $18 \%$ & 34.2 & $63 \%$ & $9 \%$ \\
\hline
\end{tabular}

Source: Zietsman, 2005 (23)

On average, each bridge does not experience tremendous delays. However, the delay is greatly increased during peak times during the day. Table 27 shows the amount of trucks observed along with the normal and creep idle times experienced for four travel modes.

Table 27. Idling, Creep Idling, and Volumes Per Travel Mode

\begin{tabular}{|c|c|c|c|c|c|c|}
\hline \multirow{2}{*}{$\begin{array}{c}\text { Travel } \\
\text { Mode }\end{array}$} & $\begin{array}{c}\text { Volume } \\
\text { (veh/day) }\end{array}$ & $\begin{array}{c}\text { Normal } \\
\text { idle time } \\
\text { (min) }\end{array}$ & $\begin{array}{c}\text { Creep idle } \\
\text { time (min) }\end{array}$ & $\begin{array}{c}\text { Volume } \\
\text { (veh/day) }\end{array}$ & $\begin{array}{c}\text { Normal } \\
\text { idle time } \\
\text { (min) }\end{array}$ & $\begin{array}{c}\text { Creep idle } \\
\text { time (min) }\end{array}$ \\
\hline $\begin{array}{c}\text { Off- } \\
\text { peak/FAST }\end{array}$ & 90 & 4.1 & 4.2 & 89 & 7.1 & 2.3 \\
\hline $\begin{array}{c}\text { Off- } \\
\text { peak/Non- } \\
\text { FAST }\end{array}$ & 420 & 16.5 & 3.7 & 432 & $33.9 *$ & 5.1 \\
\hline Peak/FAST & 140 & 8.5 & 3.2 & 141 & 20.8 & 1.7 \\
\hline $\begin{array}{c}\text { Peak/Non- } \\
\text { FAST }\end{array}$ & 651 & $9.5 *$ & 5.2 & 683 & $11.4 *$ & $2.4 *$ \\
\hline
\end{tabular}

* These values are adjusted by providing different weights because only $1 \%$ of the cases represent extensively long crossing times.

Source: Zietsman, 2005 (23)

Also part of the study was actual collection of emission rate values from trucks crossing the border. Using specialized equipment and analyses the researchers determined emission rates for NOx, HC, CO, and PM (see Table 28). 
Table 28. Emission Rates for Idling and Creep Idling

\begin{tabular}{|c|c|c|c|c|c|}
\hline Truck Type & $\begin{array}{c}\text { Idling } \\
\text { mode }\end{array}$ & $\begin{array}{c}\text { NOx } \\
(\mathbf{g} / \mathbf{h r})\end{array}$ & $\begin{array}{c}\text { HC } \\
(\mathbf{g} / \mathbf{h r})\end{array}$ & $\begin{array}{c}\mathbf{C O} \\
(\mathbf{g} / \mathbf{h r})\end{array}$ & $\begin{array}{c}\text { PM } \\
(\mathbf{g} / \mathbf{h r})\end{array}$ \\
\hline \multirow{2}{*}{ HDDV 8 } & Normal & 72.29 & 8.96 & 19.56 & 1.06 \\
\cline { 2 - 6 } & Creep & 105.16 & 11.04 & 54.59 & 1.53 \\
\hline \multirow{2}{*}{ HDDV 6 } & Normal & 54.85 & 15.05 & 48.44 & 0.65 \\
\cline { 2 - 6 } & Creep & 94.32 & 12.92 & 32.44 & 0.81 \\
\hline
\end{tabular}

Source: Zietsman, 2005 (23)

Utilizing the emission rates and delay values found in the previous TTI report and focusing on the NOx emission levels, annual NOx emission values were calculated (see Table 29). With the FSS system capturing cross-border movements, it is expected that over 278 tons of NOx emissions will be eliminated in the El Paso region.

Table 29. NOx Emissions Associated with Border Crossing Trips

\begin{tabular}{|r|l|c|c|c|}
\hline \multicolumn{2}{|c|}{ Year } & $\begin{array}{c}\text { Border Delay w/o FSS } \\
\text { (tons) }\end{array}$ & $\begin{array}{c}\text { Border Delay w/FSS } \\
\text { (tons) }\end{array}$ & Difference (tons) \\
\hline $\mathbf{1}$ & $\mathbf{2 0 1 4}$ & 30.98 & 25.06 & -5.92 \\
\hline $\mathbf{2}$ & $\mathbf{2 0 1 5}$ & 31.66 & 25.84 & -5.82 \\
\hline $\mathbf{3}$ & $\mathbf{2 0 1 6}$ & 31.94 & 25.58 & -6.36 \\
\hline $\mathbf{4}$ & $\mathbf{2 0 1 7}$ & 32.06 & 25.11 & -6.95 \\
\hline $\mathbf{5}$ & $\mathbf{2 0 1 8}$ & 32.95 & 25.15 & -7.80 \\
\hline $\mathbf{6}$ & $\mathbf{2 0 1 9}$ & 33.42 & 24.55 & -8.87 \\
\hline $\mathbf{7}$ & $\mathbf{2 0 2 0}$ & 32.45 & 23.34 & -9.11 \\
\hline $\mathbf{8}$ & $\mathbf{2 0 2 1}$ & 33.65 & 23.26 & -10.39 \\
\hline $\mathbf{9}$ & $\mathbf{2 0 2 2}$ & 32.69 & 22.06 & -10.63 \\
\hline $\mathbf{1 0}$ & $\mathbf{2 0 2 3}$ & 34.16 & 22.12 & -12.03 \\
\hline $\mathbf{1 1}$ & $\mathbf{2 0 2 4}$ & 33.25 & 20.90 & -12.34 \\
\hline $\mathbf{1 2}$ & $\mathbf{2 0 2 5}$ & 34.72 & 21.19 & -13.53 \\
\hline $\mathbf{1 3}$ & $\mathbf{2 0 2 6}$ & 34.24 & 20.77 & -13.47 \\
\hline $\mathbf{1 4}$ & $\mathbf{2 0 2 7}$ & 34.49 & 20.65 & -13.84 \\
\hline $\mathbf{1 5}$ & $\mathbf{2 0 2 8}$ & 34.69 & 21.30 & -13.38 \\
\hline $\mathbf{1 6}$ & $\mathbf{2 0 2 9}$ & 34.45 & 21.82 & -12.63 \\
\hline $\mathbf{1 7}$ & $\mathbf{2 0 3 0}$ & 35.08 & 22.08 & -13.00 \\
\hline $\mathbf{1 8}$ & $\mathbf{2 0 3 1}$ & 34.71 & 21.53 & -13.18 \\
\hline $\mathbf{1 9}$ & $\mathbf{2 0 3 2}$ & 35.37 & 21.60 & -13.76 \\
\hline $\mathbf{2 0}$ & $\mathbf{2 0 3 3}$ & 35.03 & 20.97 & -14.05 \\
\hline $\mathbf{2 1}$ & $\mathbf{2 0 3 4}$ & 35.58 & 20.91 & -14.67 \\
\hline $\mathbf{2 2}$ & $\mathbf{2 0 3 5}$ & 35.26 & 20.28 & -14.98 \\
\hline $\mathbf{2 3}$ & $\mathbf{2 0 3 6}$ & 35.83 & 20.23 & -15.61 \\
\hline $\mathbf{2 4}$ & $\mathbf{2 0 3 7}$ & 35.92 & 19.92 & -16.00 \\
\hline $\mathbf{T o t a l s}$ & $\mathbf{5 1 4 . 5 7}$ & -278.35 \\
\hline
\end{tabular}




\section{Power}

For this analysis it is assumed the power would come from the existing electrical grid in El Paso, thus producing emissions to account for in this analysis. The power production emission inputs and calculations are shown in Table 30.

\section{Table 30. Power Production Emission Inputs and Calculations}

\begin{tabular}{|lcl|}
\hline \multicolumn{3}{c|}{ Inputs } \\
\hline Cruise energy including acceleration & 0.354 & kwh per mile (each unit) \\
Distance & 10 & miles \\
NOx stack emissions & 1.6 & pounds per MWh (max) \\
\hline \multicolumn{3}{c}{ Calculations } \\
\hline Power consumption for 10 mile system & 3.54 & kwh \\
NOx emitted per unit for 10 mile system & 0.0057 & pounds per unit \\
\hline
\end{tabular}

The final annual calculation of the amount of NOx emissions involves multiplying the NOx emitted per unit for the 10-mile system shown in Table 30 and the total number of FSS trips per year. The annual NOx emission totals are presented in Table 31. Over the 24-year analysis period a total of 29.09 tons of NOx emissions would be produced to power the transporters across the border. 
Table 31. Calculated NOx Emissions Produced from Power Generation for FSS Operations

\begin{tabular}{|c|c|c|c|c|}
\hline \multicolumn{2}{|c|}{ Year } & Total FSS Trips Per Year & Nox (pounds) per year & Nox (tons) per year \\
\hline $\mathbf{1}$ & $\mathbf{2 0 1 4}$ & 218,564 & $1,237.9$ & 0.62 \\
\hline $\mathbf{2}$ & $\mathbf{2 0 1 5}$ & 214,924 & $1,217.3$ & 0.61 \\
\hline $\mathbf{3}$ & $\mathbf{2 0 1 6}$ & 234,552 & $1,328.5$ & 0.66 \\
\hline $\mathbf{4}$ & $\mathbf{2 0 1 7}$ & 256,439 & $1,452.5$ & 0.73 \\
\hline $\mathbf{5}$ & $\mathbf{2 0 1 8}$ & 287,789 & $1,630.0$ & 0.82 \\
\hline $\boldsymbol{6}$ & $\mathbf{2 0 1 9}$ & 327,372 & $1,854.2$ & 0.93 \\
\hline $\mathbf{7}$ & $\mathbf{2 0 2 0}$ & 336,206 & $1,904.3$ & 0.95 \\
\hline $\boldsymbol{8}$ & $\mathbf{2 0 2 1}$ & 383,369 & $2,171.4$ & 1.09 \\
\hline $\mathbf{9}$ & $\mathbf{2 0 2 2}$ & 392,136 & $2,221.1$ & 1.11 \\
\hline $\mathbf{1 0}$ & $\mathbf{2 0 2 3}$ & 444,061 & $2,515.2$ & 1.26 \\
\hline $\mathbf{1 1}$ & $\mathbf{2 0 2 4}$ & 455,522 & $2,580.1$ & 1.29 \\
\hline $\mathbf{1 2}$ & $\mathbf{2 0 2 5}$ & 499,344 & $2,828.3$ & 1.41 \\
\hline $\mathbf{1 3}$ & $\mathbf{2 0 2 6}$ & 497,070 & $2,815.4$ & 1.41 \\
\hline $\mathbf{1 4}$ & $\mathbf{2 0 2 7}$ & 510,792 & $2,893.1$ & 1.40 \\
\hline $\mathbf{1 5}$ & $\mathbf{2 0 2 8}$ & 493,838 & $2,797.1$ & 1.32 \\
\hline $\mathbf{1 6}$ & $\mathbf{2 0 2 9}$ & 466,205 & $2,640.6$ & 1.36 \\
\hline $\mathbf{1 7}$ & $\mathbf{2 0 3 0}$ & 479,856 & $2,717.9$ & 1.38 \\
\hline $\mathbf{1 8}$ & $\mathbf{2 0 3 1}$ & 486,183 & $2,753.7$ & 1.44 \\
\hline $\mathbf{1 9}$ & $\mathbf{2 0 3 2}$ & 507,834 & $2,876.4$ & 1.47 \\
\hline $\mathbf{2 0}$ & $\mathbf{2 0 3 3}$ & 518,584 & $2,937.3$ & 1.53 \\
\hline $\mathbf{2 1}$ & $\mathbf{2 0 3 4}$ & 541,170 & $3,065.2$ & 1.63 \\
\hline $\mathbf{2 2}$ & $\mathbf{2 0 3 5}$ & 552,760 & $3,130.8$ & $3,261.5$ \\
\hline $\mathbf{2 3}$ & $\mathbf{2 0 3 6}$ & 575,835 & $3,345.0$ & \\
\hline $\mathbf{2 4}$ & $\mathbf{2 0 3 7}$ & 590,564 & & \\
\hline
\end{tabular}

\section{Combined Emission Analysis}

The combined change in NOx emissions with implementing the FSS system is shown in Table 32. The FSS system results in a total reduction of 695.87 tons of NOx emissions in El Paso over the 14-year period, which translates into almost a 23 percent reduction in the final year.

The associated elimination of NOx emissions provides a monetary benefit to the region of over $\$ 3.8$ million $^{3}$ for the 24 -year analysis period.

\footnotetext{
${ }^{3}$ Utilizes \$13,000 per ton for NOx emissions from: Texas Commission on Environmental Quality, Texas Emission Reduction Plan, Chapter 11, p. 3. Austin, TX. May 2006.
} 
Table 32. Summary of NOx Emission Changes with FSS Implementation

\begin{tabular}{|c|c|c|c|c|c|c|c|c|c|c|c|}
\hline \multirow[b]{3}{*}{ Year } & \multirow[b]{3}{*}{$\begin{array}{l}\text { Total FSS Trips } \\
\text { Per Year }\end{array}$} & \multicolumn{10}{|c|}{ NOx } \\
\hline & & \multicolumn{3}{|c|}{ Current Scenario } & \multicolumn{5}{|c|}{ Freight Shuttle Scenario } & \multirow[b]{2}{*}{$\begin{array}{c}\text { Diff. } \\
\text { (tons) }\end{array}$} & \multirow[b]{2}{*}{$\begin{array}{c}\text { Diff. } \\
(\%)\end{array}$} \\
\hline & & $\begin{array}{c}\text { Truck w/o } \\
\text { FSS }\end{array}$ & $\begin{array}{c}\text { Border Delay w/o } \\
\text { FSS }\end{array}$ & $\begin{array}{c}\text { Total w/o } \\
\text { FSS }\end{array}$ & $\begin{array}{l}\text { Truck } \\
\text { w/FSS }\end{array}$ & $\begin{array}{c}\text { Border Delay } \\
\text { w/FSS }\end{array}$ & $\begin{array}{c}\text { Terminal } \\
\text { Delay } w / F S S\end{array}$ & Power & $\begin{array}{c}\text { Total } \\
w / F S S\end{array}$ & & \\
\hline 1 & 218,564 & 120.54 & 30.98 & 151.52 & 111.04 & 25.06 & 0 & 0.62 & 136.71 & -14.81 & -9.77 \\
\hline 2 & 214,924 & 123.18 & 31.66 & 154.84 & 113.83 & 25.84 & 0 & 0.61 & 140.27 & -14.56 & -9.40 \\
\hline 3 & 234,552 & 124.26 & 31.94 & 156.20 & 114.06 & 25.58 & 0 & 0.66 & 140.31 & -15.89 & -10.17 \\
\hline 4 & 256,439 & 124.71 & 32.06 & 156.77 & 113.56 & 25.11 & 0 & 0.73 & 139.39 & -17.37 & -11.08 \\
\hline 5 & 287,789 & 128.19 & 32.95 & 161.14 & 115.67 & 25.15 & 0 & 0.82 & 141.64 & -19.50 & -12.10 \\
\hline 6 & 327,372 & 130.03 & 33.42 & 163.46 & 115.80 & 24.55 & 0 & 0.93 & 141.28 & -22.18 & -13.57 \\
\hline 7 & 336,206 & 126.26 & 32.45 & 158.72 & 111.64 & 23.34 & 0 & 0.95 & 135.94 & -22.78 & -14.35 \\
\hline 8 & 383,369 & 130.93 & 33.65 & 164.58 & 114.26 & 23.26 & 0 & 1.09 & 138.61 & -25.97 & -15.78 \\
\hline 9 & 392,136 & 127.16 & 32.69 & 159.85 & 110.11 & 22.06 & 0 & 1.11 & 133.28 & -26.57 & -16.62 \\
\hline 10 & 444,061 & 132.88 & 34.16 & 167.04 & 113.57 & 22.12 & 0 & 1.26 & 136.95 & -30.09 & -18.01 \\
\hline 11 & 455,522 & 129.36 & 33.25 & 162.61 & 109.55 & 20.90 & 0 & 1.29 & 131.75 & -30.86 & -18.98 \\
\hline 12 & 499,344 & 135.08 & 34.72 & 169.80 & 113.37 & 21.19 & 0 & 1.41 & 135.97 & -33.83 & -19.92 \\
\hline 13 & 497,070 & 133.21 & 34.24 & 167.45 & 111.59 & 20.77 & 0 & 1.41 & 133.77 & -33.68 & -20.11 \\
\hline 14 & 510,792 & 134.18 & 34.49 & 168.68 & 111.97 & 20.65 & 0 & 1.45 & 134.07 & -34.61 & -20.52 \\
\hline 15 & 493,838 & 134.95 & 34.69 & 169.64 & 113.48 & 21.30 & 0 & 1.40 & 136.18 & -33.46 & -19.72 \\
\hline 16 & 466,205 & 134.03 & 34.45 & 168.48 & 113.76 & 21.82 & 0 & 1.32 & 136.89 & -31.59 & -18.75 \\
\hline 17 & 479,856 & 136.48 & 35.08 & 171.56 & 115.62 & 22.08 & 0 & 1.36 & 139.05 & -32.51 & -18.95 \\
\hline 18 & 486,183 & 135.03 & 34.71 & 169.74 & 113.89 & 21.53 & 0 & 1.38 & 136.80 & -32.94 & -19.41 \\
\hline 19 & 507,834 & 137.59 & 35.37 & 172.96 & 115.51 & 21.60 & 0 & 1.44 & 138.55 & -34.41 & -19.89 \\
\hline 20 & 518,584 & 136.28 & 35.03 & 171.30 & 113.73 & 20.97 & 0 & 1.47 & 136.17 & -35.13 & -20.51 \\
\hline 21 & 541,170 & 138.41 & 35.58 & 173.99 & 114.88 & 20.91 & 0 & 1.53 & 137.32 & -36.66 & -21.07 \\
\hline 22 & 552,760 & 137.17 & 35.26 & 172.43 & 113.14 & 20.28 & 0 & 1.57 & 134.98 & -37.45 & -21.72 \\
\hline 23 & 575,835 & 139.42 & 35.83 & 175.25 & 114.38 & 20.23 & 0 & 1.63 & 136.24 & -39.01 & -22.26 \\
\hline 24 & 590,564 & 139.76 & 35.92 & 175.68 & 114.08 & 19.92 & 0 & 1.67 & 135.67 & -40.01 & -22.77 \\
\hline
\end{tabular}




\subsection{REDUCTION IN DIESEL CONSUMPTION}

Many of the benefits are related to the reduced VMT attributed to the FSS system. A portion of the trucks that would have otherwise driven to the border crossing would travel to the FSS terminal, located a short distance from the border crossing. Considering only the El Paso portion of the trip a reduction of over 47.9 million VMT over the 24 years would result from implementing the FSS. This equates to the reduced consumption of approximately 7.5 million gallons of diesel fuel. This calculation is shown in Table 33.

Table 33. Change in El Paso Diesel Fuel Consumed with FSS Implementation

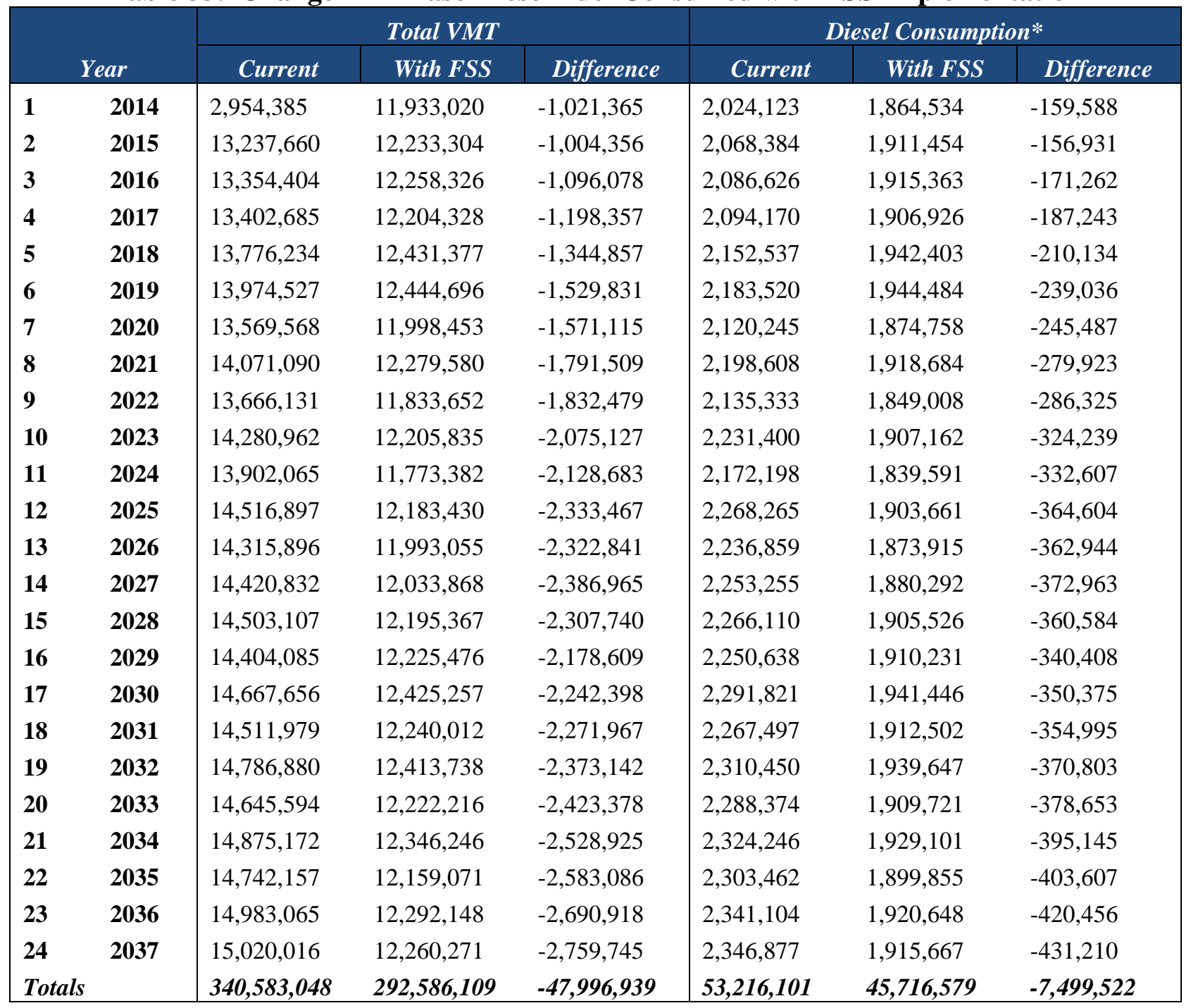

*Note: Truck fuel efficiency $=6.4 \mathrm{mph}$ in calculation $(24)$ 


\subsection{BORDER CROSSING DELAY - TRUCKING SAVINGS}

Using the calculated delay times at the border crossings at each segment of the border crossing process previously shown in Table 27, the overall delay is calculated for the levels of trucks currently crossing the border crossings and the levels of trucks that would instead utilize the FSS system. Over the 24-year analysis period there would be a reduction of over 3.1 million hours of delay with the incorporation of the FSS system. Considering a value of time for trucking of $\$ 76.29$ per hour, the calculated NPV for avoided delay is $\$ 102,277,820$ (25).

\subsection{ECONOMIC IMPACTS AND JOB CREATION}

It is well established that undertaking infrastructure projects provides positive economic impacts. In an effort to stimulate the economy, the U.S. federal government implemented several competitive grant programs for transportation infrastructure projects. The TIGER and TIGER II grant programs required applicants to emphasize the economic impacts associated with construction and continued operations of the infrastructure project.

As with other major infrastructure projects, constructing the FSS system will provide positive economic impacts in the El Paso region. Economic impacts will result from the one-time construction of the system, along with ongoing operations of the system. Table 34 shows the positive economic impacts associated with the 10-mile FSS system proposed for the El Paso region would approach $\$ 2$ billion over the life of the project.

Table 34. Total 10-mile FSS Economic Impact

\begin{tabular}{|c|c|}
\hline Expenditure Type & Economic Impact \\
\hline One Time Construction & $\$ 399,895,432$ \\
\hline Ongoing & $\$ 1,598,493,385$ \\
\hline Total Economic Impact & $\$ \mathbf{1 , 9 9 8 , 3 8 8 , 8 1 8}$ \\
\hline
\end{tabular}

Note: One time construction costs $=$ total expenditures times multiplier of 3.59; Ongoing costs $=$ transporter costs times multiplier of 3.41 ; terminal operations costs times multiplier of 3.27 .

Additionally, the U.S. federal government estimates that for every $\$ 92,000$ expended on the project, one job-year will be created. For this project, the number of calculated job-years created is equal to 2,206 job-years (26).

\subsection{ADDITIONAL BENEFITS}

\section{Partnerships}

As indicated in Chapter 4, the most likely border crossing location will be at the existing Ysleta-Zaragoza Port of Entry. The Ysleta-Zaragoza Port of Entry, originally constructed in 1938 and rebuilt in 1955 and 1990, includes two structures: a four-lane commercial bridge and a five-lane non-commercial bridge. Listed as 804 feet in length, the U.S. side of the bridge infrastructure is owned by the City of El Paso and the Mexico side is owned by Capufe (Caminos 
y Puentes Federales), a Mexico federal agency in charge of the construction of all toll roads and bridges in Mexico (27), (28). An El Paso MPO presentation indicates that the toll bridge is operated by the concessionaire PROMOFRONT (29).

Chapter 6 extensively discusses the framework necessary to incorporate the construction of new infrastructure across the border. Generally, constructing a new cross-border bridge involves a long, relatively political process in which opposing forces work to benefit from the location. With the FSS system, there is unilateral support for the construction of the FSS system at the existing Ysleta-Zaragoza Port of Entry. With this unanimous support, the regulatory hurdles are largely minimized and should result in the ability to amend the existing treaty in order to support the construction of the FSS system either on or adjacent to the existing Ysleta-Zaragoza Port of Entry bridge structures.

\section{Livability}

Examining the freight terminal and warehousing activities in El Paso and Ciudad Juarez shows steady growth of these facilities throughout the entire region. In El Paso large clusters of industrial areas exist and, as discussed in Chapter 4, could provide a good location for the FSS terminal location. The FSS terminal will act as a major attractor of truck movements. Locating the terminal within or close to an already existing or planned industrial area reduces the length of truck trips on the region's highways. Additionally, the terminal will provide economic development opportunities for compatible industrial development adjacent to the terminal. This consolidation and/or development of freight activities around the FSS terminal supports economic development, reduces the truck trips throughout the region, and provides positive economic benefits for the region.

\section{Security}

Discussed extensively throughout this report, the FSS provides a secure system that will inspect 100 percent of the containers that cross the border for potential hazards. Overall the system will reduce the number of trucks at the border crossings to be handled by current labor-intensive inspections; provide an elevated, secure guideway operated with non-stop movements across the border; and pushes the cargo examination away from the border into secure terminal locations. The envisioned security methodologies fit into existing CBP initiatives designed to increase and improve security screening at the border.

\subsection{BENEFITS REVIEW}

This chapter assessed the benefits associated with the implementation of the FSS that would accrue to the region, maquiladoras and shippers. Implementing the FSS system would reduce the emissions from trucks traveling to the border crossings and waiting at the border inspection/processing facilities. The reduced waiting at the border crossing facilities also will save the consumption of diesel. Additionally, significant positive economic impacts will accrue from the construction and continued operation of the system, including the creation of jobs for the region. Table 35 summarizes the benefits calculated in this chapter. 
Table 35. Summary of the Benefits Accrued by Implementing the FSS System

\begin{tabular}{|c|c|}
\hline Benefit & NPV \\
\hline Emissions & $\$ 3,802,164$ \\
\hline Border Delay & $\$ 102,277,820$ \\
\hline Economic Impact & $\$ 1,998,388,818$ \\
\hline Benefit & Value \\
\hline Diesel Fuel Saved & $7,499,522$ gallons \\
\hline Job-Years Created & 2,206 job-years \\
\hline
\end{tabular}



APPENDIX A:

SURVEY APPLIED TO MAQUILADORAS IN THE REGION

\section{The Freight Shuttle System Federal Initiative}

The Texas Transportation Institute (TTI) is developing a project in the El Paso/Ciudad Juarez region. This project seeks to analyze the receptivity of regional shippers to an intermodal transport alternative based on performance parameters and costs. This project requires information from shippers and carriers that operate in the region. The focus of this interview is to capture information related to cross-border operations in the El Paso/Ciudad Juarez region.

\section{Contact Information}

\section{Interview Guide}

Name

Organization

Position

Address

Telephone email

I. Trip Characteristics (in the routes: Juarez-El Paso and/or El Paso-Juarez)

1. Do you experience any seasonal fluctuations in your cross-border operations? (Please specify)

2. Do you hold any inventory?
$\square$ Yes, in Juarez
$\square$ Yes, in El Paso
$\square$ No

3. Have you find peak hours in your cross-border operations? (Please specify)

4. Are you able to schedule your company's shipments?

$\square$ Yes, I can decide when a shipment should be ready

No, shipments are ready at specific times; I cannot reschedule

No, shipments are ready at different times without schedule

5. Are you willing to spread your shipments' schedule throughout the day if this reduces your transportation costs?

$\square$ Yes, I would reschedule for lower transportation costs

No, I cannot reschedule 
6. Currently, how do you manage your company's shipments?

$\square$ Shipments are carried by the company (internal transportation)

$\square$ Hire one carrier company

$\square$ Hire two or more carrier companies

7. Approximately, how much is the actual cost of every shipment/container per unit?

$\square$ US\$0 to US $\$ 50$

$\square$ US\$50 to US $\$ 100$

$\square$ US $\$ 100$ to US $\$ 150$

US $\$ 150$ to US $\$ 200$

US $\$ 200$ or more

8. Are there any other costs related to your shipments?

$\square$ Yes (specify) (approx. cost)US\$

No

9. For each statement, please mark the cell that better describes your possible decision:

\begin{tabular}{|c|c|c|}
\hline The New Border Crossing System: & \multicolumn{2}{|c|}{ I would pay for each shipment, between: } \\
\hline $\begin{array}{l}\text { Significantly reduces border-crossing times } \\
\text { but doesn't simplify inspections }\end{array}$ & $\begin{array}{l}\square \text { US } \$ 60-\text { US } \$ 80 \\
\square \text { US } \$ 80-\text { US } \$ 100 \\
\square \text { US } \$ 100-\text { US } \$ 120 \\
\square \text { US } \$ 120 \text { - US } \$ 140\end{array}$ & $\begin{array}{c}\square \text { US } \$ 140-\text { US } \$ 160 \\
\text { US } \$ 160-\text { US } \$ 180 \\
\text { US } \$ 180-\text { US } \$ 200 \\
\text { I would not use/pay } \\
\text { the new system }\end{array}$ \\
\hline $\begin{array}{l}\text { Simplifies inspections but doesn't reduce } \\
\text { border-crossing times }\end{array}$ & $\begin{array}{l}\square \text { US } \$ 60-\text { US } \$ 80 \\
\square \text { US } \$ 80-\text { US } \$ 100 \\
\square \text { US } \$ 100 \text { - US } \$ 120 \text { - US } \$ 140\end{array}$ & $\begin{array}{c}\square \text { US } \$ 140 \text { - US } \$ 160 \\
\square \text { US } \$ 160-\text { US } \$ 180 \\
\square \text { US } \$ 180-\text { US } \$ 200 \\
\text { I would not use/pay } \\
\text { the new system }\end{array}$ \\
\hline $\begin{array}{l}\text { Neither reduces border-crossing times nor } \\
\text { simplifies inspections }\end{array}$ & $\begin{array}{l}\square \text { US } \$ 60-\text { US } \$ 80 \\
\square \text { US } \$ 80-\text { US } \$ 100 \\
\square \text { US } \$ 100-\text { US } \$ 120 \\
\square \text { US } \$ 120 \text { - US } \$ 140\end{array}$ & $\begin{array}{c}\square \text { US } \$ 140-\text { US } \$ 160 \\
\text { US } \$ 160-\text { US } \$ 180 \\
\text { US } \$ 180-\text { US } \$ 200 \\
\text { I would not use/pay } \\
\text { the new system }\end{array}$ \\
\hline $\begin{array}{l}\text { Significantly reduces border-crossing times } \\
\text { and simplifies inspections }\end{array}$ & $\begin{array}{l}\square \text { US } \$ 60-\text { US } \$ 80 \\
\square \text { US } \$ 80-\text { US } \$ 100 \\
\square \text { US } \$ 100-\text { US } \$ 120 \\
\square \text { US } \$ 120 \text { - US } \$ 140\end{array}$ & $\begin{array}{c}\square \text { US } \$ 140-\text { US } \$ 160 \\
\text { US } \$ 160-\text { US } \$ 180 \\
\square \text { US } \$ 180-\text { US } \$ 200 \\
\text { I would not use/pay } \\
\text { the new system }\end{array}$ \\
\hline
\end{tabular}




\section{APPENDIX B:}

\section{BORDER-CROSSING ANALYSIS}

\section{BRIDGE OF THE AMERICAS (BOTA)}

BOTA consists of two adjacent bridges, one for northbound and southbound traffic, with two dedicated truck lanes on the outside of each bridge - 4 commercial lanes total. The two lanes entering the U.S. convert into three commercial lanes: 1 Fast Lane and 2 regular. Commercial traffic services are limited to 6:00 am to 6:00 pm (weekdays and until 2:00 pm on Saturdays) for northbound traffic and 8:00 am to 9:00 pm for southbound traffic. There are no tolls on BOTA. The U.S. side of the bridge is owned by the City of El Paso and the Mexican side is owned by CAPUFE. There are a total of 4 (2-northbound and 2-southbound) commercial lanes. There is Customs, Immigration, and Agricultural on both sides of the border. This POE has very limited vacant land in its surroundings as shown below; though, there is vacant land inside both customs yards (see Figure 31).

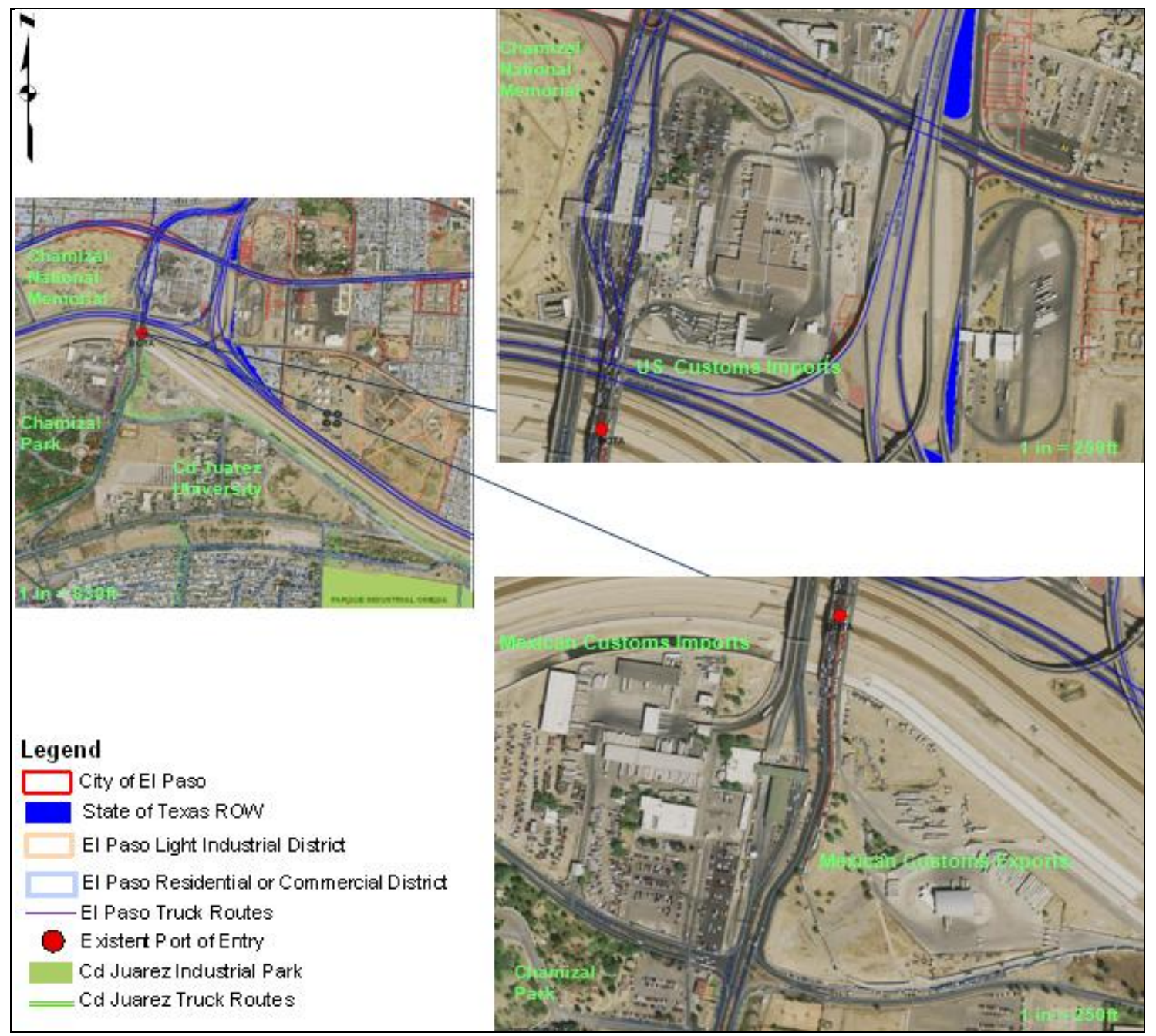

Figure 31. Bridge of the Americas (BOTA) _ FSS Border Crossing Alternative No.2 


\section{SANTA TERESA, NM}

The Santa Teresa is located 10 miles west of the El Paso City Limits, but has good connectivity to I-10. Commercial vehicle operating hours is from 8:00 am to 6:00 pm, Monday through Saturday. There is one primary inspection booth for commercial vehicles entering the U.S. and one entering Mexico; however, there is no Fast Lane program for trucks in this POE. There are Customs, Immigration, and Agricultural inspections in both sides of the border. This POE has plenty of vacant land in its surroundings that will allow the establishment of inspection terminals (see Figure 32).

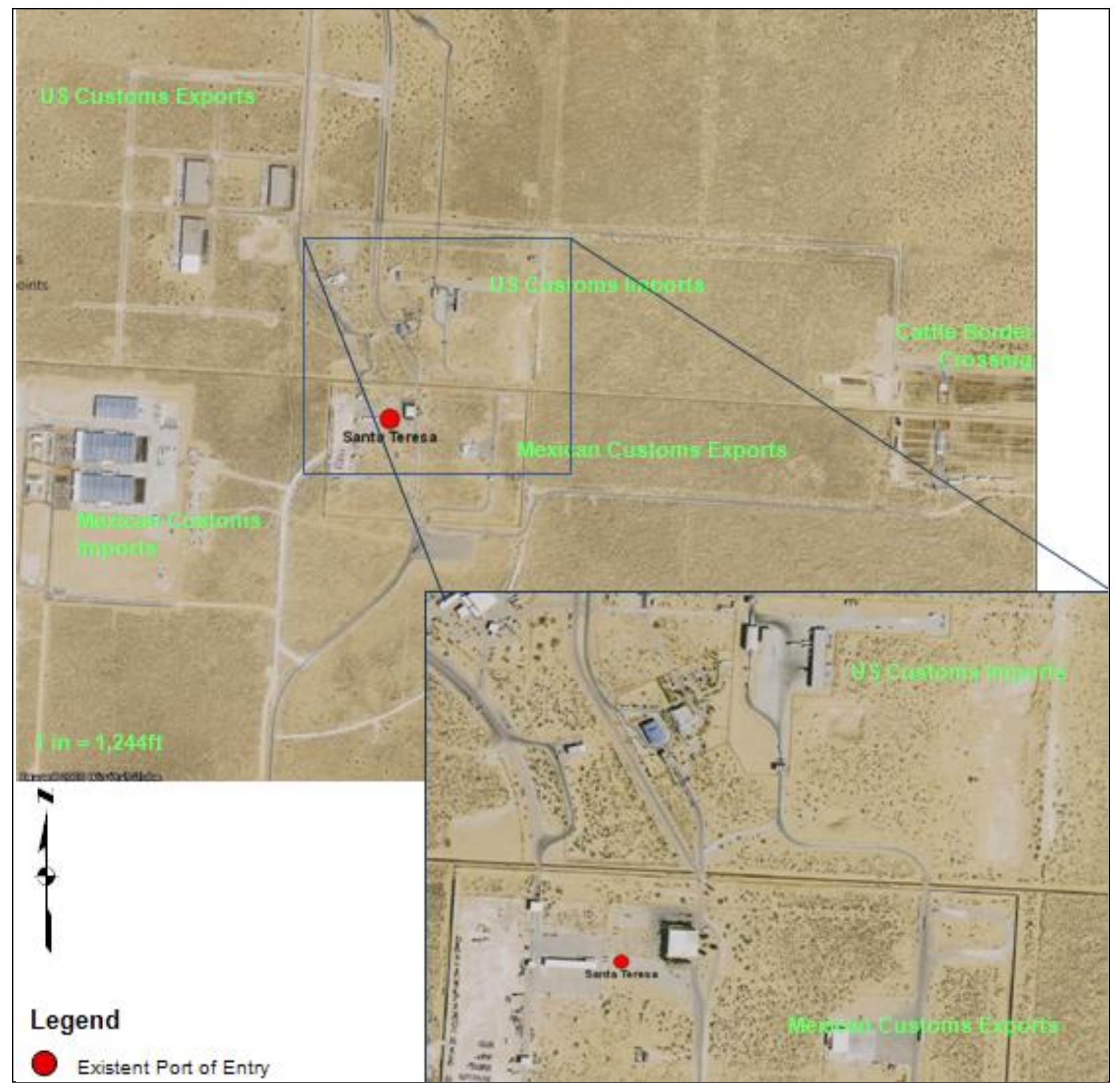

Figure 32. Santa Teresa Port of Entry—FSS Border Crossing Alternative No.3 
APPENDIX C:

PROCESS FOR EVALUATION OF PROPOSALS FOR NEW BORDER

CROSSINGS AND BRIDGES IN THE U.S. AND MEXICO

\section{INTERPRETATIVE GUIDANCE ON EXECUTIVE ORDER 11423}

DEPARTMENT OF STATE

[Public Notice 5699]

Bureau of Western Hemisphere Affairs; Office of Canadian Affairs; Interpretative Guidance on Non-Pipeline Elements of E.O. 13337, amending E.O. 11423

AGENCY: Department of State.

ACTION: Notice.

SUMMARY: Executive Order 11423, of August 16, 1968, as amended, authorizes the Secretary of State to issue Presidential permits for the construction of facilities crossing the international borders of the United States, including, but not limited to, bridges and tunnels connecting the United States with Canada or Mexico. Section 2(a) of Executive Order 13337, dated April 30, 2004, amended Executive Order 11423, inter alia, by authorizing the Secretary of State to issue Presidential permits for " border crossings for land transportation, including motor or rail vehicles, to or from a foreign country, whether or not in conjunction with the facilities" to which Executive Order 11423 previously applied. This new language is found in section 1(a)(vi) of Executive Order 11423, as amended.

In seeking to provide guidance to the public concerning its exercise of this new permitting authority, the Department has determined, after giving the matter careful consideration, that the new "land border crossing" language of section 1(a)(vi) will apply to all new crossings of the international border as well as to all substantial modifications of existing crossings of the international border. The Department assembled an interagency working group, consisting of relevant State Department personnel and personnel from other interested Federal agencies, to prepare further guidance on application of this interpretation of section 1(a)(vi) in the future. Over the course of two years, this working group studied how to implement the new and amended Executive Orders in an efficient manner. DOS intends to review this guidance periodically with participants in the interagency working group, and may modify or amend it accordingly. The guidance document and annexes are quoted in full below, under SUPPLEMENTARY INFORMATION.

FOR FURTHER INFORMATION CONTACT: Mr. Alex Lee, Director, WHA/CAN, U.S. Department of State, Washington, DC 20520. (202) 647-2170.

\section{SUPPLEMENTARY INFORMATION:}

Department of State Interpretative Guidance on Non-Pipeline Elements of E.O. 13337, amending E.O. 11423 


\section{Background}

Executive Order (E.O.) 11423 (August 16, 1968) specifies that the proper conduct of the foreign relations of the United States requires that executive permission be obtained for the construction and maintenance at the borders of the United States of facilities connecting the United States with a foreign country. By virtue of E.O. 11423, as amended by E.O. 13337 (April 30, 2004), the President has delegated to the U.S. Department of State (DOS) the authority to receive applications for, and to approve and issue, Presidential permits for the construction, connection, operation, or maintenance of certain facilities at the borders of the United States with Canada and Mexico. Pursuant to section 3(b) of E.O. 13337, subsection 2(b) of E.O. 11423 and DOS Notice of Interpretation (Public Notice 5149), 70 FR 45,748 (2005), DOS determined that this authority applied to all new border crossings $\backslash 1 \backslash$ and to all substantial modifications of existing border crossings of the international border.

Substantial modifications are defined as follows:

1. An expansion beyond the existing footprint $\backslash 2 \backslash$ of a land port-of-entry (LPOE) inspection facility, $\backslash 3 \backslash$ including its grounds, approaches, and appurtenances, at an existing border crossing in such a way that the modification effectively constitutes a new piercing of the border;

2. a change in ownership of a border crossing that is not encompassed within or provided for under an applicable Presidential permit;

3. a permanent change in authorized conveyance (e.g., commercial traffic, passenger vehicles, pedestrians, etc.) not consistent with (a) What is stated in an applicable Presidential permit, or (b) current operations if a Presidential permit or other operating authority $\backslash 4 \backslash$ has not been established for the facility; or

4. any other modification that would render inaccurate the definition of covered U.S. facilities set forth in an applicable Presidential permit.

The following categories of border crossings are covered by this guidance:

- Bridges

- Tunnels

- Roadway crossings

- Rail crossings

- Bicycle crossings

- Pedestrian crossings

- Cross-border material/commodity conveyors

- Livestock crossings

Note, however, that activities covered by Congressional authorization and not dependent on executive permission under E.O. 11423 and E.O. 13337 are outside the scope of this guidance. With the assistance of an interagency working group, $15 \backslash$ DOS has prepared the following 
guidance to clarify the types of non-pipeline projects under E.O. 11423 and E.O. 13337 that require Presidential permits and to provide guidelines for the preparation of applications for Presidential permits to facilitate an expeditious DOS response.

\section{Presidential Permits: Purpose and Guiding Principles}

It is the policy of the United States to work with Canada and Mexico to facilitate safe, fast, and efficient border transit, while ensuring U.S. national security. Within this context, E.O. 13337 was promulgated with the intent to "expedite reviews of permits" and "to provide a systematic method for the evaluation and permitting the construction and maintenance of certain border crossings for land transportation $* * *$ while maintaining safety, public health and environmental protections." Implicit in DOS stewardship of the Presidential permit process is recognition that border crossings are, by definition, international in nature. Successful implementation of border-crossing projects requires good intra- and inter-governmental communications, and careful consideration of the foreign relations implications of a proposed project.

Taking into account input from appropriate federal agencies and other interested participants, DOS has the responsibility to determine whether a proposed border-crossing project is in the U.S. national interest. Within the context of appropriate border security, safety, health, and environmental requirements, DOS notes that it is generally in the U.S. national interest to facilitate the efficient movement of legitimate goods and travelers across U.S. borders.

DOS and other Federal agencies further recognize that a subset of important improvements and modifications to border crossings may not require Presidential permits, and that it is in the national interest not to impose unnecessary delays and burdens on the sponsors of such improvements.

\section{Project Sponsor}

A project sponsor is an entity that has ownership, jurisdiction, custody, or control of the U.S. portion of a border crossing. A Presidential permit will only be issued to such an entity. This may be a federal, state, or local government entity, or a private individual or group.

If at the time of application, a future transfer of ownership is anticipated and the identity of the future owner is known (e.g., from a local port authority to GSA), the applicant should notify DOS in its application of that anticipated change so that provision may be made when the Presidential permit is granted for the transfer of the Presidential permit to the future owner.

\section{Notification}

A new border crossing or substantial modification to an existing border crossing must have a new or amended Presidential permit, as applicable. For purposes of determining whether a new or amended permit is required, DOS has identified three categories of projects based on the magnitude and complexity of the proposed change(s) at the border:

- Red (both DOS notification and new or amended Presidential permit required); 
- Yellow (DOS notification required and a Presidential permit may be required); and

- Green (neither DOS notification nor Presidential permit required).

DOS should also be notified of changes to all facilities that comprise or feed proximately into the international border crossing (including LPOE inspection facilities or state or federal access or egress roadways) that reasonably could be expected to have a material effect on Canadian or Mexican government operations in their countries.

The Required Project Notification Information (see attached Exhibit A) will be used by the sponsor to notify DOS of either projects or modifications in the "Red" or "Yellow" categories.

A project sponsor may consult with DOS to determine a project's likely classification within these categories before submitting Required Project Notification Information to DOS. Indeed, DOS would encourage such advance consultations and, if there is a question regarding a project's color code status, the sponsor should consult with DOS as early as possible after it establishes project parameters and implementation plans. A description of the three categories follows below.

- Red: This category covers all new border crossings and those proposed changes that make a substantial modification to an existing border crossing, including particularly, expansion beyond the existing footprint of an LPOE inspection facility in such a way that the modification effectively constitutes a new piercing of the border. The addition of lanes to an existing border crossing or the replacement of existing lanes with new lanes is not a substantial modification and falls under the yellow category. In all red category cases, a Presidential permit application must be submitted and approved before construction activities begin. In an emergency situation, the sponsor should contact DOS for case-specific guidance before taking any action. This would not, however, prevent the sponsor from performing or contracting for other project due diligence activities as warranted and at its own risk (e.g., preparation of environmental documentation under the National Environmental Policy Act of 1969, as amended (NEPA); project design; other permit applications; etc.), while DOS is deciding whether to issue the Presidential permit.

- A change in ownership of a border crossing or a permanent change in authorized conveyance if not consistent with the previously-issued Presidential permit, will require an amendment to the Presidential permit. When a Presidential permit or operating authority has not been established for a facility, a Presidential permit will be required if a permanent change in authorized conveyance is being sought that is at variance with the current operations.

- A substantial modification also could be any modification that renders inaccurate the definition of covered U.S. facilities set forth in an applicable Presidential permit.

- Yellow: Yellow category changes include modification of a border crossing that may have a material effect on Canadian or Mexican government operations in their 
respective country. If, following receipt of the Required Project Notification Information, DOS believes that a Presidential permit is required, or that additional information is required to make such a determination, DOS will respond in writing to the project sponsor within thirty (30) calendar days of receipt of the Required Project Notification Information. In the event that DOS does not approve or disapprove the proposed project within thirty (30) calendar days after confirmed receipt of the Required Project Notification Information, the project sponsor shall give a second written notice to DOS requesting approval. In the event DOS does not approve or disapprove the proposed project within 30 days after such second notice is given, the project sponsor may proceed on the basis that a Presidential permit is not required for the project.

- Green: Green category changes are those that are not expected to have a material effect on Canadian or Mexican government operations in their respective country and are not substantial modifications to the border crossing. They include most routine changes at LPOE inspection facilities near the border. Examples include changes made to government offices, inspection equipment, or routing of people and/or vehicles within U.S. border operations.

An illustrative list of activities is attached as Exhibit B to provide guidance to help determine under which category a proposed change falls.

\section{NEPA Requirements}

DOS will cooperate with other agencies to fulfill any applicable requirements under NEPA, 42 U.S.C. 4321 et seq.; implementing regulations issued by the Council on Environmental Quality, 40 CFR parts 1500-1508; and DOS implementing regulations, 22 CFR part 161. DOS and other involved federal agencies may have separate and distinct obligations under NEPA. Depending on the project, DOS may serve as the lead agency, a co-lead agency, or a cooperating agency on a project.

\section{General}

The guidance contained herein does not relieve the sponsor of the responsibility to inform DOS at the earliest opportunity of any change (policy or otherwise) at the border that could reasonably be expected to affect U.S. relations with Canada or Mexico. The sponsor should notify DOS promptly of all such planned changes, so that DOS will be in a position to facilitate expeditious resolution of any foreign policy issues that may arise in connection with proposed changes.

In furtherance of the proper conduct of the foreign relations of the United States, DOS reserves the right, notwithstanding this guidance, to take whatever steps it deems appropriate in a particular case in the exercise of its border-crossing oversight and coordination responsibilities. DOS intends to review this guidance periodically with participants in the interagency working group, and may modify or amend it accordingly. DOS welcome comments and suggestions from interested stakeholders and members of the public at any time. 


\section{Exhibit A--U.S. Department of State Required Project Notification Information Regarding Proposed Non-Pipeline Border Crossing Projects}

The information outlined in this notification, along with the project sponsor's recommended classification (Yellow--permit may be required--Department of State (DOS) notification required; Red--permit required), will be considered by DOS in determining whether a proposed non-pipeline border crossing project will require a Presidential permit. This information will be used, along with the guidelines established for implementation of E.O. 13337, amending E.O. 11423 , to determine the substantiality of any modification of an existing border crossing. DOS, however, reserves the right to require or request additional information necessary to the exercise of its border-crossing oversight and coordination responsibilities.

For applicable projects on the U.S.-Mexico border as well as those on the U.S.-Canada border, e-mail this form toWHABorder@state.gov. If e-mail is not feasible, mail to: U.S. Department of State, 2201 C St., NW. Washington, DC 20520 (Attn: WHA/MEX 4258 HST (for projects on the border with Mexico) or WHA/CAN 3917 HST (for projects on the border with Canada), as appropriate).

1. Project Sponsor (Include contact information.)

2. Project Name

3. Project Purpose/Justification

4. Project Coordination (Include a summary of existing and anticipated coordination efforts with federal, state, and/or local agencies, including contact information.)

5. Project Location (Include names of state and county; GPS coordinates, if readily available; maps showing regional location with adjacent land ports of entry, distance from international border, and whether the project is within the three-meter international boundary.)

6. Project Description (Include brief project summary describing scope of work and expected effect on existing border crossing, if applicable. This summary should include any change in the physical capacity, change of authorized conveyance (e.g., commercial to non-commercial), change of ownership, and available drawings.)

7. Project Milestones/Schedule (Include anticipated design/construction dates at a minimum.) Applicant's Suggested Categorization of the Proposed Project: Please select either "Red" or "'Yellow" based upon review of the DOS policy for implementation of E.O. 13337, considering project information as described above. Applicant may provide additional supporting documentation along with this assessment form.

[squ] Red--DOS notification required and a new or amended Presidential permit is required. [squ] Yellow--DOS notification required and a new or amended Presidential permit may be required.

\section{Exhibit B--Project Categories}

RED--DOS Notification and a New or Amended Presidential Permit Required

1. All new border crossings. 
2. An expansion beyond the existing footprint of an LPOE inspection facility, including its grounds, approaches and appurtenances, at an existing border crossing in such a way that the modification effectively constitutes a new piercing of the border; provided, however, that this does not include the addition of lanes to an existing border crossing, or the replacement of existing lanes with new lanes (see "YELLOW," below).

3. A change in ownership of a border crossing, when the existing permit does not encompass and/or provide for transfer of the facility to the new owner.

4. A permanent change in the operation of a border crossing that is not consistent with the terms of the existing Presidential permit (e.g., a permanent change in authorized conveyance). When a Presidential permit or operating authority has not been established for a facility, a Presidential permit will be required if a permanent change in authorized conveyance is being sought that is at variance with the current operations.

5. Any other modification that would render inaccurate the definition of covered U.S. facilities set forth in an applicable Presidential permit.

YELLOW--DOS Notification Required and a New or Amended Presidential Permit May Be Required

\section{Changes to Border Crossing Capacity/Traffic Flow}

1. A change in the physical capacity of the border crossing, especially permanent modifications to the border crossing itself (e.g., modification of a bridge, road access, or tunnel; expansion or reduction of traffic lanes).

2. A change in the physical capacity of an LPOE inspection facility, permanent expansion or reduction in the number of entry or exit booths or traffic lanes or other change that has a permanent effect on cross-border traffic flow (including vehicular wait times at an LPOE inspection facility).

3. A change within the three-meter boundary that has a permanent effect on traffic flow but is of a type not addressed explicitly in an existing Presidential permit (e.g., Nexus/SENTRI/FAST lanes).

4. An expansion of roadway infrastructure, or other form of increased traffic capacity within the three-meter boundary but beyond that portion of the existing right-of-way or footprint of an LPOE inspection facility.

5. A change in cross-border traffic caused by construction outside of the three-meter boundary that can be expected to have a material effect on Canadian or Mexican government operations in their respective country.

6. Major construction work having a short-term effect on traffic flow, including closure of traffic lanes for periods greater than one month, or closure of an entire LPOE inspection facility during regular operating hours for any amount of time.

Changes in Border Crossing Operation

1. A permanent change in authorized conveyance, if within the scope of the existing permit (e.g., adding pedestrian traffic or motor vehicle use).

2. Changes in Maintenance Responsibility

3. A change in the nationality of the party, the type of corporate entity, or the ownership of the entity operating the border-crossing facility. 
4. A change in the party asserting operational responsibility or custodial control over a border crossing, if other than the Presidential permit holder.

GREEN--Neither DOS Notification nor Presidential Permit Required

1. Maintenance or repair of an existing bridge, roadway, or tunnel, (other than as described in "Yellow" category), including temporary lane closures (of less than a month).

2. An interior change (renovation and/or repair) to an existing LPOE inspection facility, including any routine repair, alteration, or cyclical maintenance that, individually or collectively, is not expected to have an effect on the border crossing.

3. An exterior change within the existing footprint of an LPOE inspection facility (buildings or paving).

4. An improvement to an exterior enclosure (e.g., painting, new windows, or re-roofing) of an existing LPOE inspection facility.

5. A systems change (e.g., HVAC, electrical, or fire protection) to an existing LPOE inspection facility.

6. A change in tenant agency space assignments at an existing LPOE inspection facility.

7. A change to a border crossing or an existing LPOE inspection facility that is made at the request or direction of DOS.

8. A change in GSA or DHS operational protocols or procedures that does not have a material effect on the border crossing.

9. Placement of advanced technology (e.g., radiation portal monitors) within an existing LPOE inspection facility, or approaches located within the existing footprint of the rightof-way or an existing LPOE inspection facility.

This determination will be published in the Federal Register.

Dated: February 5, 2007.

R. Nicholas Burns, Under Secretary for Political Affairs, Department of State.

[FR Doc. E7-3123 Filed 2-22-07; 8:45 am]

BILLING CODE 4710-29-P

PROCESS FOR EVALUATION OF PROPOSALS FOR NEW BORDER CROSSINGS AND BRIDGES IN MEXICO 


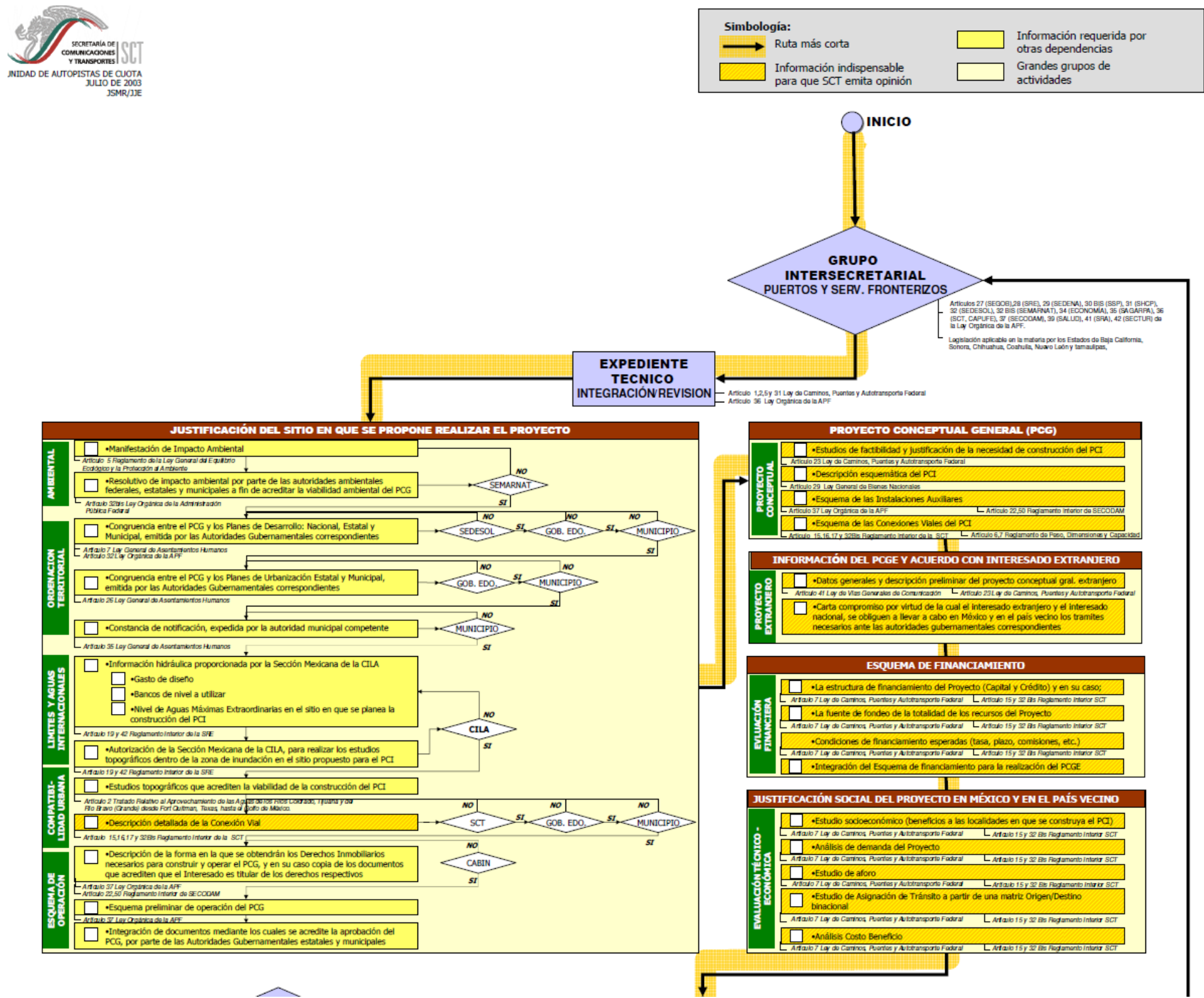

Figure 33. Process for the Evaluation of Proposals for New Border Crossings and Bridges (Part 1) 


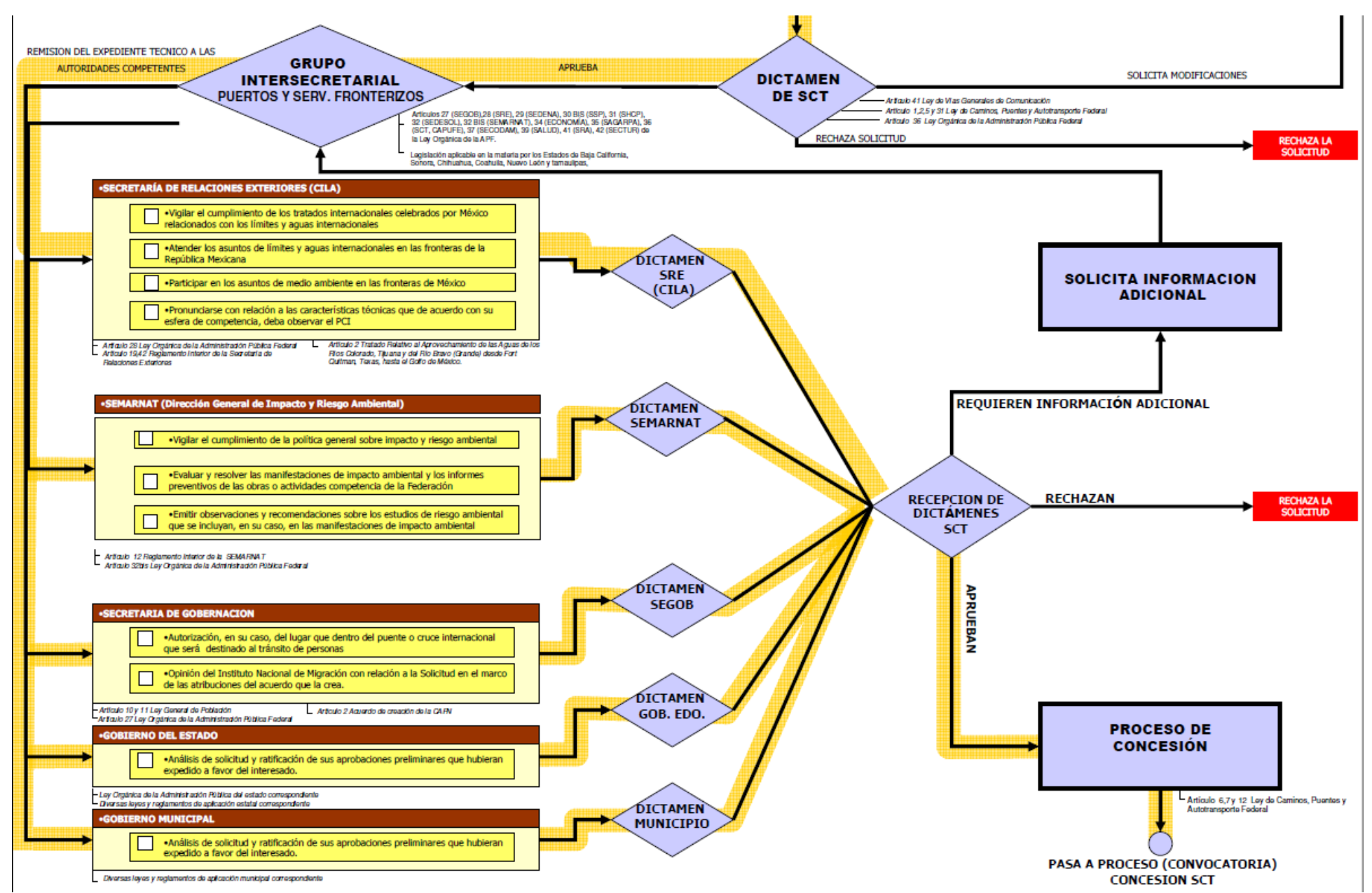

Figure 34. Process for the Evaluation of Proposals for New Border Crossings and Bridges (Part 2) 
APPENDIX D:

FSS ANNUAL DEMAND-RESULTS FROM MONTE CARLO SIMULATION (AFTER OPENING)

Table D1. FSS Annual Demand-Results from Monte Carlo Simulation

\begin{tabular}{|c|c|c|c|c|}
\hline \multirow{2}{*}{ Year } & \multirow{5}{*}{$\begin{array}{c}\text { Cross-Border } \\
\text { Truck Traffic }\end{array}$} & \multicolumn{3}{|c|}{ FSS Market Capture (Demand) } \\
\cline { 3 - 5 } & Most Likely $P_{D}$ & $\begin{array}{c}\text { 90\% Confidence } \\
\text { Interval }\end{array}$ & $\begin{array}{c}\text { 10\% Confidence } \\
\text { Interval }\end{array}$ \\
\hline 2014 & $1,143,269$ & 218,283 & 212,944 & 223,248 \\
\hline 2015 & $1,168,269$ & 214,436 & 208,005 & 220,288 \\
\hline 2016 & $1,178,572$ & 240,721 & 234,465 & 250,510 \\
\hline 2017 & $1,182,833$ & 258,886 & 251,285 & 268,722 \\
\hline 2018 & $1,215,800$ & 288,011 & 279,662 & 296,735 \\
\hline 2019 & $1,233,300$ & 334,014 & 325,139 & 347,193 \\
\hline 2020 & $1,197,561$ & 343,155 & 334,328 & 356,766 \\
\hline 2021 & $1,241,822$ & 390,220 & 380,651 & 405,135 \\
\hline 2022 & $1,206,083$ & 395,021 & 385,899 & 407,006 \\
\hline 2023 & $1,260,344$ & 450,587 & 440,346 & 465,860 \\
\hline 2024 & $1,226,905$ & 461,830 & 451,187 & 477,099 \\
\hline 2025 & $1,281,166$ & 500,679 & 489,397 & 512,998 \\
\hline 2026 & $1,263,427$ & 500,844 & 489,980 & 514,856 \\
\hline 2027 & $1,272,688$ & 513,379 & 502,118 & 526,873 \\
\hline 2028 & $1,279,949$ & 494,609 & 483,084 & 506,939 \\
\hline 2029 & $1,271,210$ & 465,587 & 452,525 & 477,690 \\
\hline 2030 & $1,294,471$ & 480,960 & 466,706 & 496,110 \\
\hline 2031 & $1,280,732$ & 486,599 & 474,419 & 498,881 \\
\hline 2032 & $1,304,993$ & 508,621 & 496,556 & 521,744 \\
\hline 2033 & $1,292,524$ & 519,134 & 504,264 & 534,221 \\
\hline 2034 & $1,312,785$ & 541,984 & 528,089 & 557,073 \\
\hline 2035 & $1,301,046$ & 553,740 & 540,548 & 567,987 \\
\hline 2036 & $1,322,307$ & 576,593 & 561,071 & 593,763 \\
\hline 2037 & $1,325,568$ & 592,203 & 573,812 & 612,174 \\
\hline 2038 & $1,319,829$ & 604,093 & 588,006 & 621,098 \\
\hline 2039 & $1,326,090$ & 616,430 & 598,823 & 635,819 \\
\hline 2040 & $1,328,351$ & 627,640 & 610,156 & 647,426 \\
\hline 2041 & $1,334,063$ & 638,521 & 619,922 & 659,251 \\
\hline 2042 & $1,339,483$ & 645,711 & 626,167 & 667,604 \\
\hline 2043 & $1,346,984$ & 657,100 & 637,686 & 679,239 \\
\hline & & & & \\
\hline
\end{tabular}




\section{REFERENCES}

1. Harrison, Robert. The Impacts of Port, Rail, and Border Dray Activity in Texas. Austin, TX : Center for Transportation Research, The University of Texas at Austin, February 2009. 0-5684-1.

2. Villa, Juan C y Bujanda, Arturo. Texas International Trade Corridor Plan. College Station, Texas 77843-3135 : Texas Transportation Institute prepared for the Executive Director of the Texas Department of Transportation, 2010.

3. Grubb \& Ellis Best/White, LLC. Markets Continue to Improve. Industrial Trends Report - Fourth Quarter 2010. El Paso, TX. [En línea] http://www.bestwhite.com/files/109_4d5c6c_doc.pdf.

4. Coliers International. 2Q 2010 Ciudad Juarez Market Analysis. [En línea] http://69.46.29.175/ colliers/CD_Juarez/Market_Reports/CD_Juarez_Industrial_Market_ Analysis_2Q2010.pdf.

5. Battelle and Texas Transportation Institute. Current State Analysis: Commercial Vehicle Crossings at the Bridge of the Americas, El Paso, Texas. 2008.

6. City of El Paso. [En línea] http://www.ci.el-paso.tx.us/international_bridges/fares.asp.

7. Texas Department of Transportation. 2010 Texas-Mexico International Bridges and Border Crossings Existing and Proposed. Austin, Texas : Texas Department of Transportation, 2010.

8. Camino Real Regional Mobility Authority. Regional Toll Implementation Plan. [En línea] 15 de April de 2010. [Citado el: 15 de December de 2010.] http://www.crrma.org/_documents/CRRMA\%20RTIP_April_15_2010\%20FINAL.pdf\#vi ew=fitH.

9. Transportation Policy Board. Mission 2035 Metropolitan Transportation Plan. [En línea] 6 de August de 2010. [Citado el: 15 de January de 2010.] http://elpasompo.org/announcements/Mission\%20MTP.pdf.

10. The City of El Paso. El Paso Regional Growth Management Plan. [En línea] [Citado el: 12 de December de 2010.] http://www.elpasotexas.gov/RGMP/index.html.

11. Ricondo \& Associates, Inc. El Paso International Airport Master Plan Update. 2005.

12. El Paso International Airport Properties Department. Air Cargo. [En línea] 6 de July de 2009. [Citado el: 10 de December de 2010.] http://www.elpasointernationalairport.com/2009/air_cargo.html.

13. Instituto Municipal de Investigacion y Planeacion. Plan de Desarrollo Urbano Ciudad Juarez 2009. Ciudad Juarez : Instituto Municipal de Investigacion y Planeacion, 2009.

14. Torteya \& Torteya, P.L.L.C. Final Report regarding Status, in Mexico, of Brownsville Navigation \& Canal District's Proposed Port Bridge Project. Port of Brownsville. [En línea] 29 de October de 2004. [Citado el: 25 de February de 2011.] http://www.portofbrownsville.com/documents/FINAL.BND.REPORT.102904.pdf.

15. Secretaria de Comunicaciones y Transportes. Proceso para Evaluación de Propuestas de Nuevos Cruces y Puentes Fronterizos de México. [En línea] July de 2003. [Citado el: 20 de February de 2011.] http://www.rovitek.com.mx/acoverx/files/1/352/6-diagrama_concesiones2_B.pdf.

16. Mexican Scretariat of the Economy,. Mexican Foreign Investment Law. [En línea] 18 de July de 2006. [Citado el: 25 de October de 2010.] http://www.sirnie.economia.gob.mx/documentos/ley_ing.doc. 
17. U.S. Department of Transportation. Phased U.S.-Mexico Cross-Border Long Haul Trucking Proposal. NAFTA Rules FMCSA Regulations. [En línea] 6 de January de 2011. [Citado el: 7 de January de 2011.] http://www.fmcsa.dot.gov/documents/crossborder/Concept-Trucks-English.pdf.

18. Ojah, Mark I, y otros, y otros. Truck Transportation through Border Ports of Entry: Analysis of Coordination Systems.

19. Baughman, Laura y Francois, Joseph. Trade Action - or Inaction: The Cost for American Workers and Companies. [En línea] 15 de September de 2009. [Citado el: 14 de April de 2011.] http://www.tradepartnership.com/pdf_files/uscc_trade_action_inaction_study_Dept_09.p df.

20. Background. Joint Advisory Committee for the Improvement of Air Quality Paso del Norte. [En línea] [Citado el: 6 de April de 2011.] http:Iwww.jacccc.org/Background.htm.

21. Center for Responsible Environmental Strategies (CRES). The Citizens of El Paso Speak on Air Quaility: Summary of Findings. Austin, TX : s.n., July 11, 2002. Report to Texas House Committee on Environmental Regulation.

22. ICF Consulting. Assessing the Effects of Freight Movement on Air Quality at the National and Regional Level. Washington, D.C. : U.S. Federal Highway Administration, April 2005.

23. Zietsman, Josias, y otros, y otros. Mexican Truck Idling Emissions at the El Paso Ciudad Juarez Border Location. College Station, TX : Southwest Region University Transportation Center, November 2005. 473700-00033.

24. American Trucking Research Institute (ATRI). An Analysis of the Operational Costs of Trucking. December 2008.

25. Quantifying the Public Impacts of Highway-Rail Grade Crossings on Surface Mobility. Protopapas, Annie, et. al. Washington, D.C. : Transportation Research Board of the National Academies, 2010, Transportation Research Record: Journal of the Transportation Research Board: No. 2149, págs. pp. 103-107.

26. Executive Office of the President of the United States. Estimates of Job Creation from the American Recovery and Reinvestment Act of 2009. Washington, D.C. : s.n., 2009.

27. HNTB, Corp. El Paso Border Operations Plan. [En línea] [Citado el: 6 de April de 2011.] http://www.epasoborderplan.org/index.php?b=ysb.

28. SAP. Capufe, Roads Without Borders. SAP Customer Success Story. [En línea] [Citado el: 6 de April de 2011.] http://www.sap.com/canada/industries/publicsector/pdf/CS_Capufe.pdf.

29. El Paso MPO. Zaragoza Facility Analysis. [En línea] [Citado el: 6 de April de 2011.] http://www.elpasompo.org/bridges/Zaragoza\%Port\%20of\%20Entry\%20Study\%202.pdf.

30. Metropolitan Planning Organization. Mission 2011-2014 Transportation Improvement Program. El Paso, TX : s.n., 2010.

31. Preqin Research Report Survey of Institutional Investor Sentiment. NY 10169 : Preqin Ltd., 2009.

32. Defusco, R.A., Pinto, J.E y Runkle, D.E., and D. E. McLeavev. Quantitative Methods for Investment Analysis. s.l. : CFA Institute, 2004.

33. El Paso Electric. Service Area. About El Paso Electric. [En línea] [Citado el: 7 de March de 2011.] www.epelectric.com/about-el-paso-electric/service-area. 
34. —. 2009 Annual Report. [En línea] [Citado el: 7 de March de 2011.] www.epelectric.com/.

35. Caldwell, Stephen. Supply Chain Security: Challenges to Scanning 100 Percent of U.S.Bound Cargo Containers. Washington, D.C. : Government Accountability Office, June 12, 2008. GAO-08-533T.

36. Products and Solution. American Science and Engineering, Inc. [En línea] 21 de April de 2010. http://www.as-e.com/products_solutions/technology.asp. 